Historic, archived document

Do not assume content reflects current scientific knowledge, policies, or practices. 



\section{TUCKER-MOSBY SEED CO.}

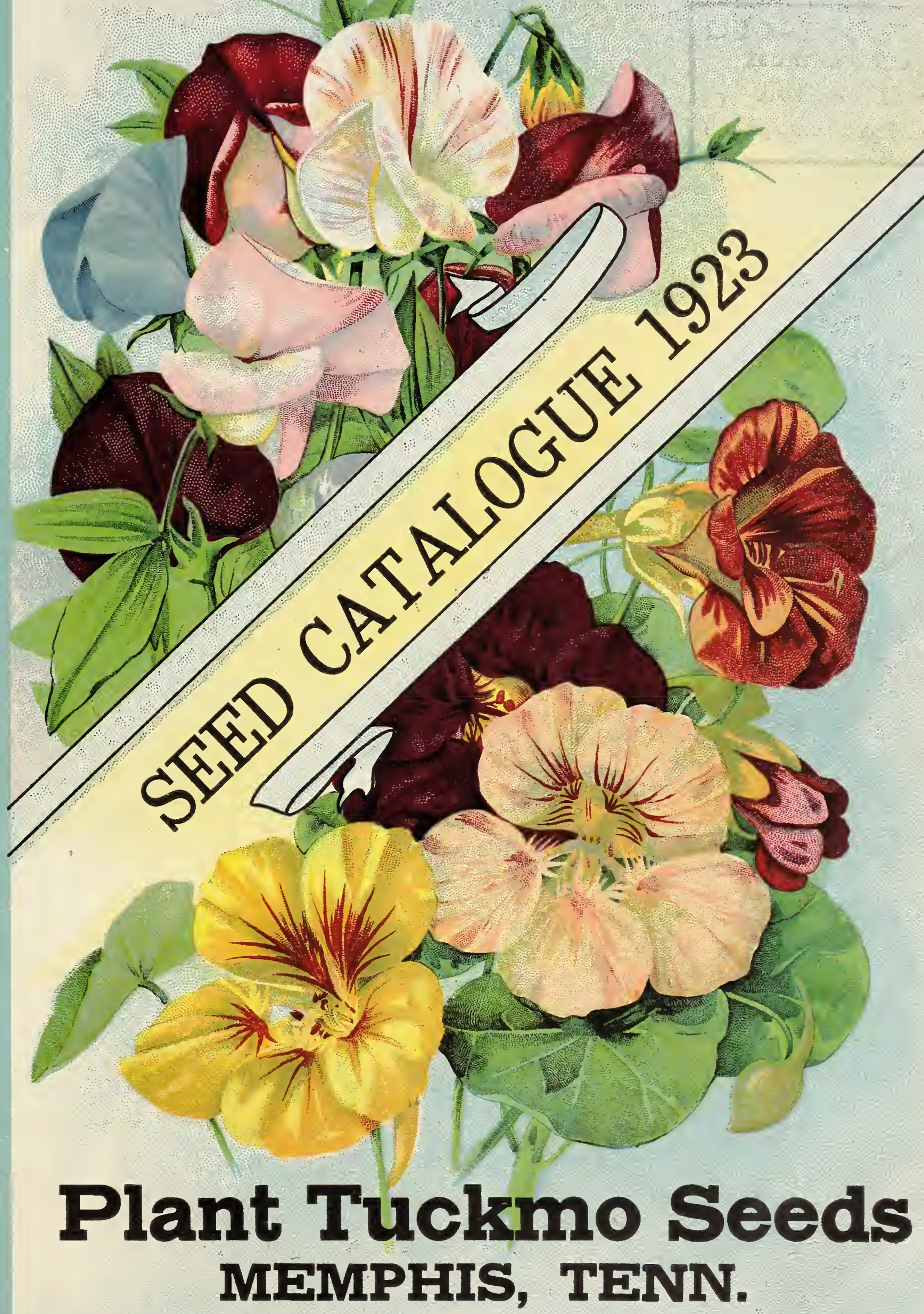




\section{TUCKER-MOSBY SEED COMPANY SPRING CATALOGUE 1923 INSTRUCTIONS AS TO PARCEL POST RATES}

All parcels of seeds, bulbs and plants, up to and including $8 \mathrm{oz}$. at the rate of $1 \mathrm{c}$ for each 2 oz. regardless of distance; over $8 \mathrm{oz}$, at the Zone Rate. All merchandise other than seeds, bulbs and plants up to and including $4 \mathrm{oz}$. in weight can be sent at the rate of $1 \mathrm{c}$ an ounce regardless of distance. Over 4 oz. at the Zone Rate.

Limit of weight for delivery within local, first, second and third zones, 70 pounds; to all other zones, 50 pounds. If weight exceeds this we will pack in 2 or 3 parcels, provided sufficient money is remitted to cover postage on goods and weight of packing.

A fraction of a pound is considered a full pound.

Zone

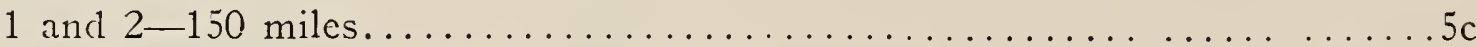

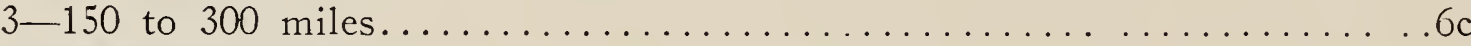

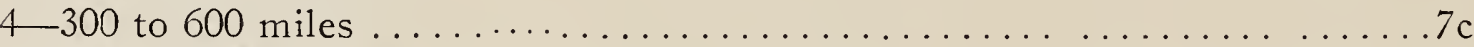

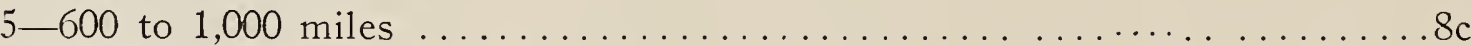

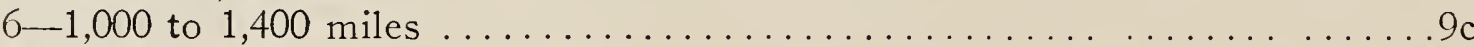

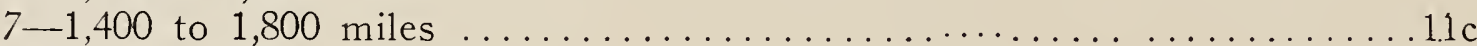

8 -All over 1,800 miles

Each

Additional

Pound

$1 c$
$2 c$
$4 c$
$6 c$
$8 c$
$10 c$
$12 c$

\section{INFORMATION AND TERMS OF SALE}

OUR TERMS ARE MONEY WITH ORDER. Money can be safely sent by postoffice money order, express order or registered letter. Postage stamps remittance in small amounts are also satisfactory. C. O. D. We do not under any consideration send goods C. O. D. unless 50 per cent of the amount accompanies the order. Cash in full must be sent for seed by mail.

FLUCTUATION OF PRICES. Seed Potatoes, Onion Sets, Grass and Clover Seed, Grain and other Field Seeds fluctuate in prices, depending upon the market condition and supplies.

COMPLAINTS. All claims must be made on receipt of goods. We are very anxious at all times to please our customers, and at any time any cause for complaint should be made, please do not hesitate to report to us, and we will adjust same to the best of our ability. We pack all seeds in good strong bags, and deliver to the Transportation Company in good order. Frequently, however, through rough handling, bags are torn and contents are partially lost. Where such is the case, please do not receive goods from the Transportation Company until expense bill is marked "Received in Bad Order." Then if you cannot get a settlement from the Agent, send us the Expense Bill, report to us the amount of damage, and we will undertake the collection of the claim.

NAME AND ADDRESS SHOULD ALWAYS BE GIVEN. Frequently we receive letkers unsigned. Sometimes they contain money and orders. Sometimes, also, letters are received in which the name of the town is left out and the postmark is blurred. We cannot fill orders unless we know the name and address of the buyer. The easiest way for you is to use our order sheet, filling in the blanks.

PARCEL POST. A table of Parcel Post rates will be found above.

WARRANTING SEEDS. Tucker-Mosby Seed Co. gives no warranty, express or implied, as to description, purity, productiveness or any other matter, of any seeds they send out, and will not be in any way responsible for the crops. If the purchaser does not accept the goods on these terms, they are to be returned at once.

\section{INDEX}

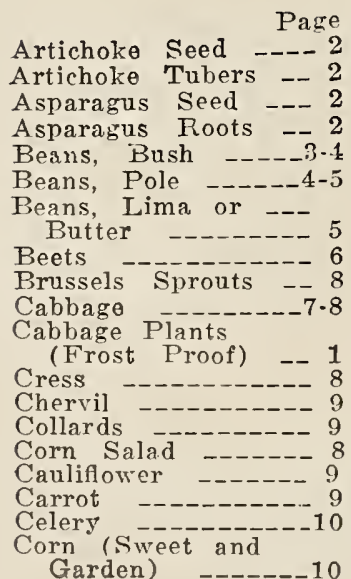

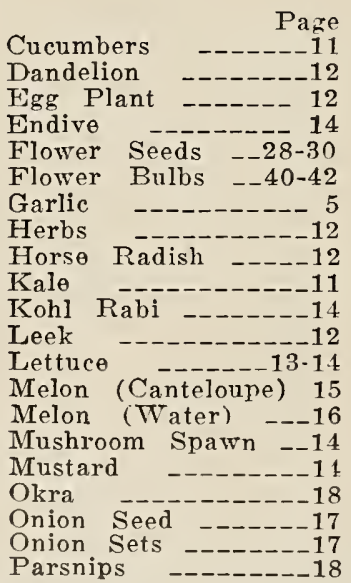

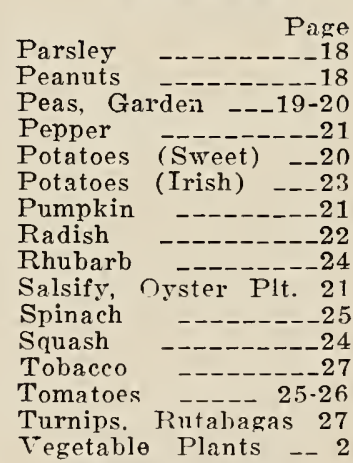

FIELD SEEDS

Alfalfa.

Begar weed Giant

Buckwheat

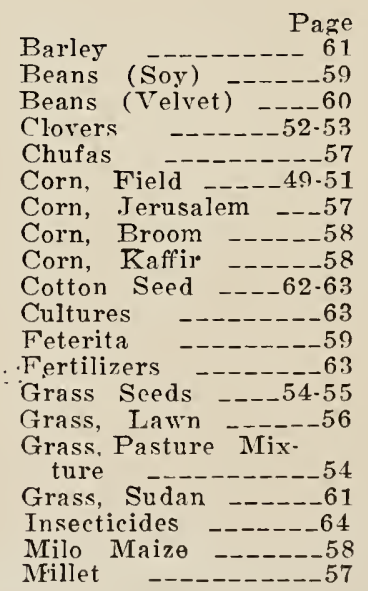




\section{ORDER SHEET \\ Tucker-Mosby Seed Company}

TUCKMO BRAND SEEDS

60 SO. FRONT STREET

MEMPHIS, TENN.

Shall we ship by Mail,.Freight or Express.........

Name

Post Office

Box No

R. F. D. No.

State

Street No.

Ship to (Station)

By Express or R. R. Co.

Please write $\mathrm{Fame}$ and Address very plainly in the above.

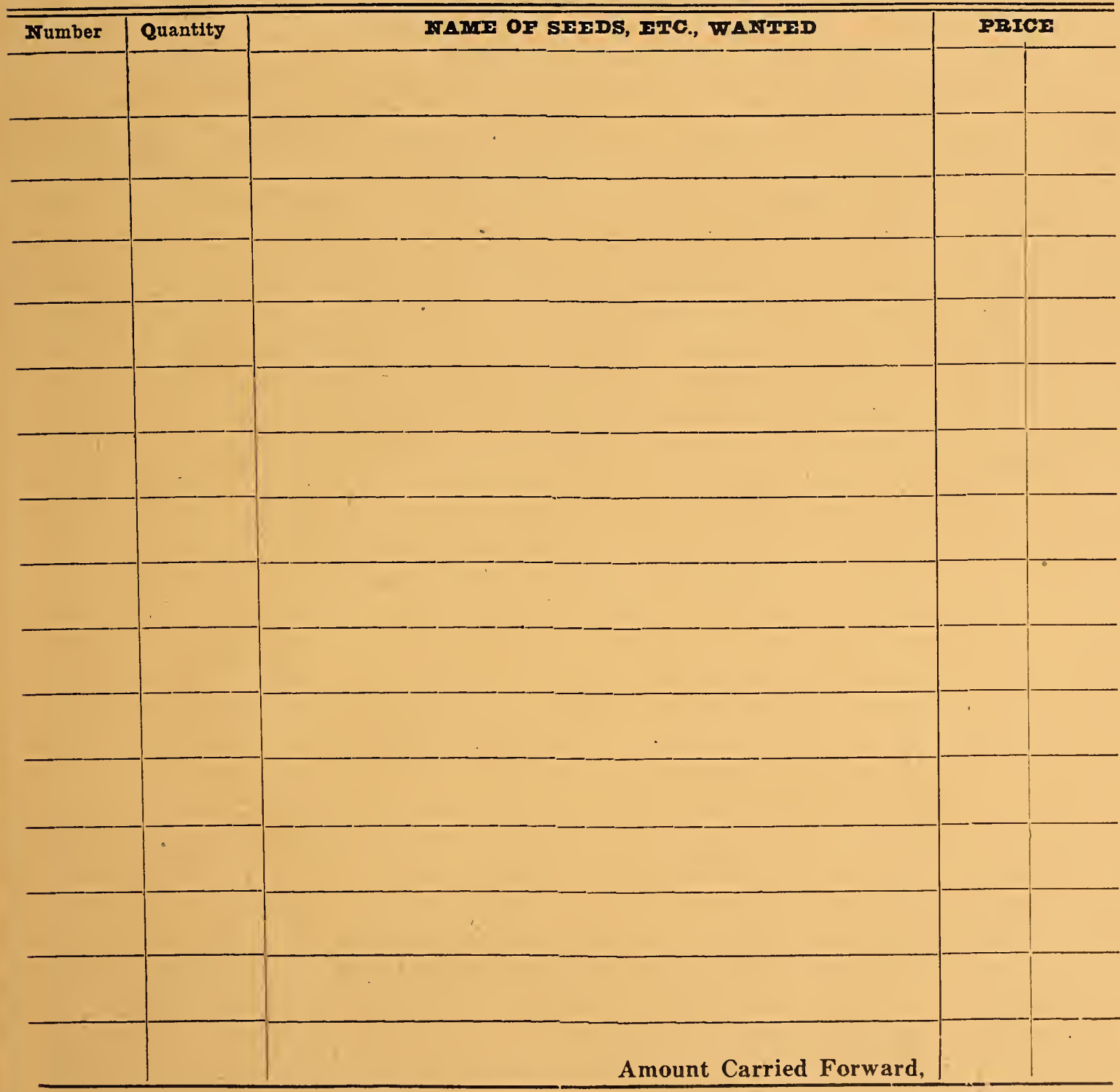

so.

Date rec'd

Checked by.

wrapped by

Date Sent.

P

THE AMOUNT FRCIOSED

Exp. Money Order $\$$

P. O. Money Order

Bank Draft .....

Stamps ......

Cash ........

Total

...

Date

$192 \ldots$ 


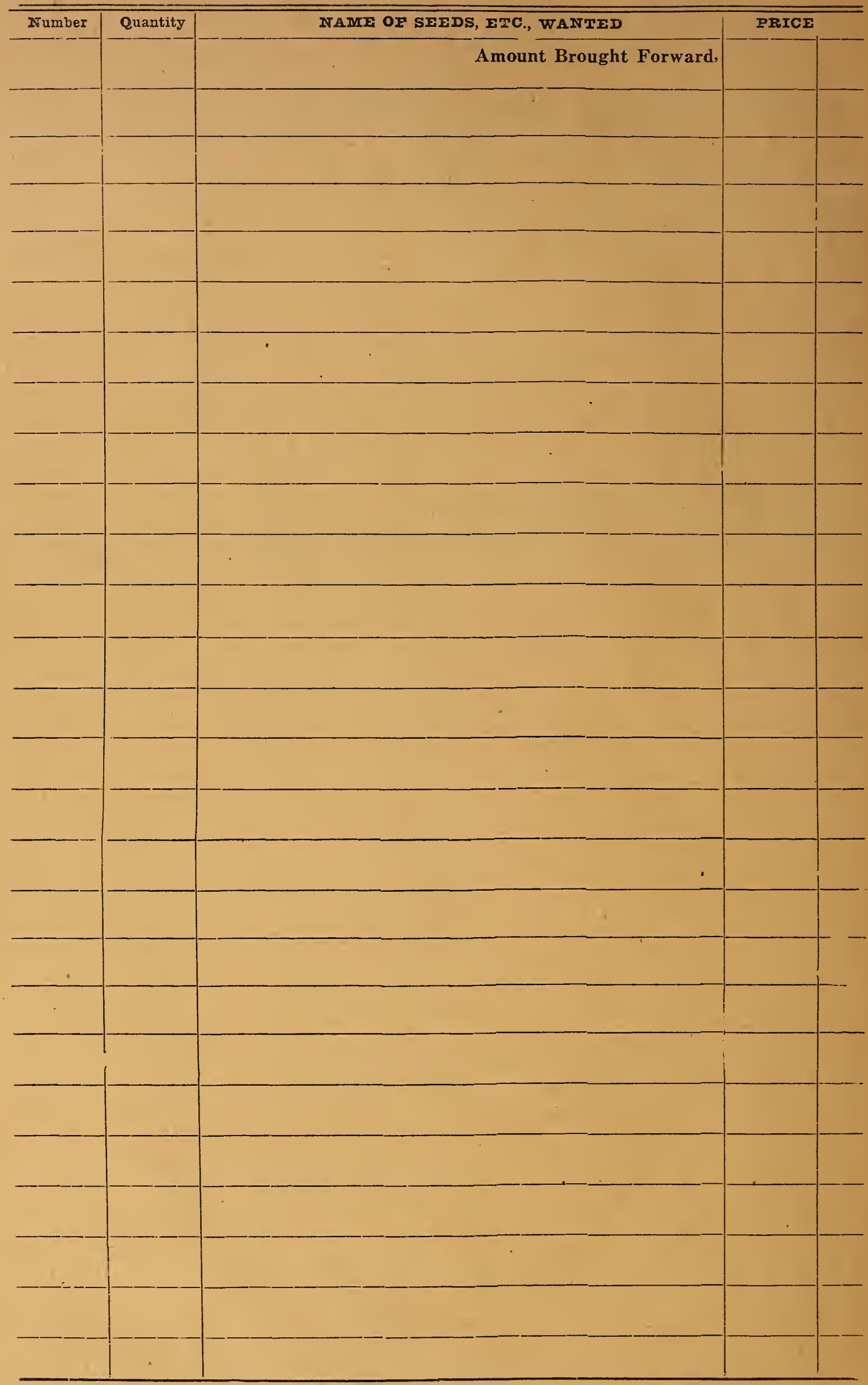



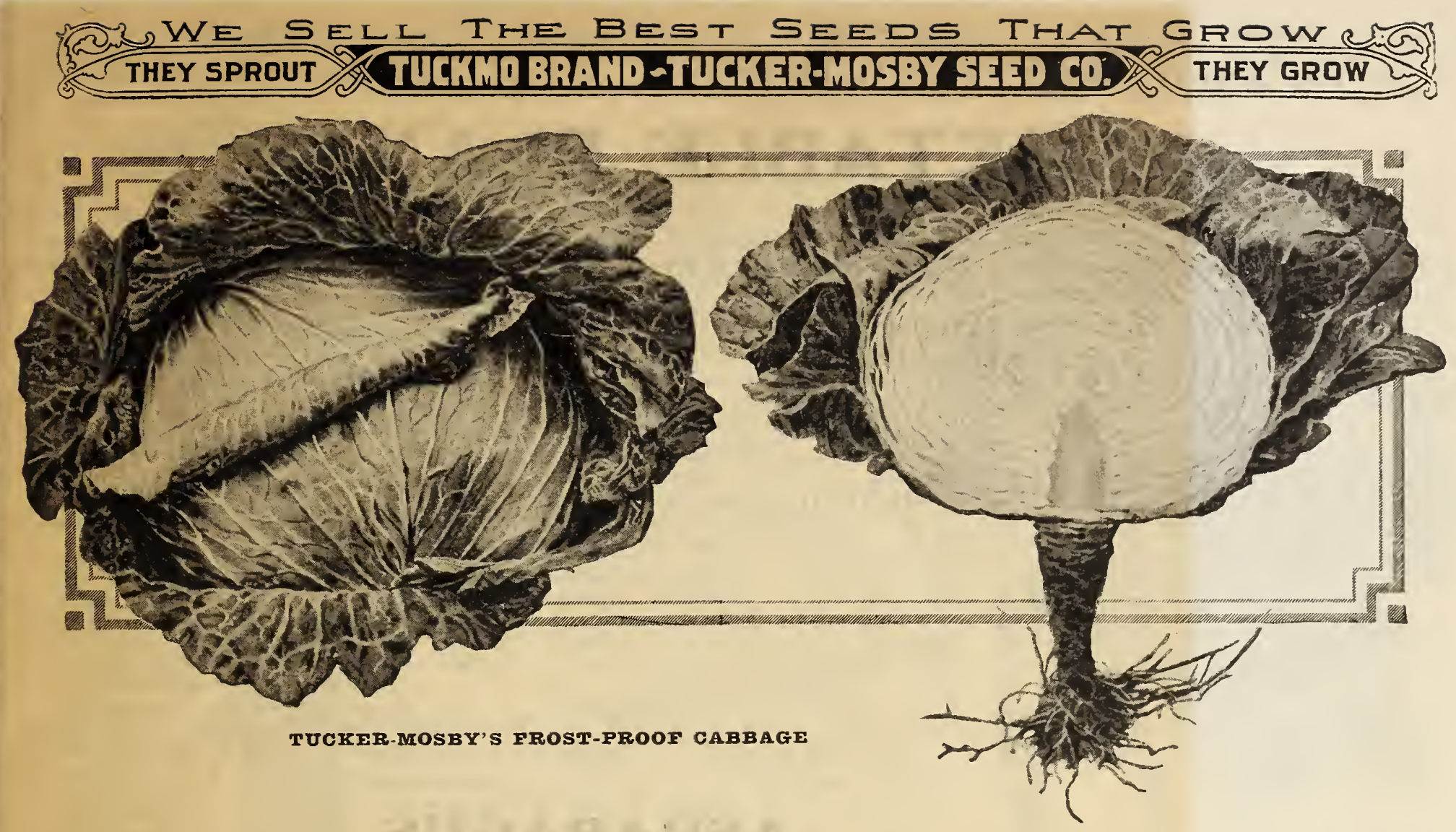

\section{Tucker-Mosby Seed Co's Frost-Proof Cabbage Plants Will Mature Heads Two to Three Weeks Earlier Than Your Home Grown Plants and DOUBLE YOUR PROFITS. WHY?}

The plants make a slow but steady growth, until at eight or ten weeks of age they are very tough and hardy, the buds are purple and outer leaves a reddish brown. When in this condition they can be shipped to territory farther north and be planted in the open ground a month to six weeks sooner than the home-grown hotbed or cold frame plants. These FROST-PROOF CABBAGE PLANTS will stand a temperature of twenty degrees above zero without injury, the land freezing, or the plants being covered with ice, sleet or snow after they are planted will not injure them.

The top of the plant does not grow until your regular Spring weather opens up, but the roots grow from the time they are planted, and just as soon as Spring weather starts, the established root growth assimilates the fertilizer in the soil, the plants grow very fast, maturing headed cabbage two to three weeks sooner than you can mature them from hotbed and cold frame plants. You know what the difference in profit will be if your crop is matured and marketed before the general crop from home-grown plants is matured.

TO GET THE ADVANTAGE OF THESE FROST-PROOF .CABBAGE PLANTS THEY MUST BE PLANTED A MONTH OR SIX WEEKS EARLIER THAN YOU WOULD PLANT HOME-GROWN PLANTS.

Our cabbage plants are grown from the best Long Island grown seed. We can fill orders from December 1 st to May 1st.

The plants when received will be somewhat wilted and have a hard stunted appearance, which will be disappointing to persons who have never used these plants before. Regardless of appearance, they will produce the crop results. On account of congested transportation, we do not guarantee delivery Our responsibility ceases upon delivery of plants to postoffice or transportation company.

\section{VARIETIES-EARLY JERSEY WAKEFIELD, CHARLESTON LARGE TYPE WAKEFIELD. SUCCESSION AND EARLY FLAT DUTCH.}

Prices by Parcel post, postage paid, 50c per hundred, 200 to 500 plants at $40 \mathrm{c}$ per hundred; 1,000 plants, $\$ 3.50$. Plants packed 100 to 1,000 to the package for parcel post shipment.

Prices by Express, buyer paying charges, 1,000 to 4,000. $\$ 2.50$ per thousand: 5.000 to 8,000 , $\$ 2.25$ per thousand; 10,000 and over, $\$ 2.00$ per thousand.

TERMS CASH WITH ORDER. No plants shipped C. O. D. 


\section{VEGETABLE PLANTS}

All orders for vegetable plants will be filled in season when plants are in light condition, and at the right time.

We can supply in any quantity, in their proper seasons, all vegetable plants here mentioned, and ship directly from beds, well packed, on the shortest notice. NOTICE-If we should for any reason be out of any variety ordered, we will send some other similar variety in place of it, unless requested to the contrary.

BRUSSELS SPROUTS PLANTS

Ready in March and up to May.
Prices, doz. 25c;50 for $60 \mathrm{c} ; 100$ for $\$ 1.00$, parcel post paid. By express, not prepaid doz. $20 \mathrm{c} ; 50$ for $45 \mathrm{c} ; 100$ for $85 \mathrm{c}$.

\section{BEET PLANTS}

Ready in March and up to May. Eclipse Early Detroit Crosby Egyptian Prices, 50 for $35 \mathrm{c} ; 100$ for $60 \mathrm{c}$, parcel post paid $25 \mathrm{c} ; 100$ for $45 \mathrm{c} ; 500$ for $\$ 2.00$.

\section{CAULIFLOWER PLANTS}

Ready in March and up to May.

Early Snowball Dry Weather

Prices, doz, 25c; 50 for $60 \mathrm{c} ; 100$ for $\$ 1.00$, parcel post paid. By express, not prepaid, doz., $20 \mathrm{c} ; 50$ for $50 \mathrm{c} ; 100$ for $85 \mathrm{c}$.

\section{CELERY PLANTS}

Ready in April and up to June.

White Plume Golden Self-Blanching Prices, doz. $25 \mathrm{c} ; 50$ for $50 \mathrm{c} ; 100$ for $75 \mathrm{c}$ : 500 for $\$ 2.50$; parcel post paid. By express, not prepaid, doz. $15 \mathrm{c} ; 50$ for $40 \mathrm{c}$ 100 for $65 \mathrm{c} ; 500$ for $\$ 2.25$.

\section{SWEET POTATO PLANTS}

Ready in April and up to July. Florida Yam Early Triumph Gold Coin Bunch Yam Nancy Hall Bunch Yellow Yam Southern Queen Porto Rica Yam Slips Yellow Yam

Prices, 100 for $40 \mathrm{c} ; 500$ for $\$ 1.75 ; 1000$ for $\$ 3.25$, parcel post paid. By express, not prepaid, 100 for $30 \mathrm{c} ; 1000$ for $\$ 2.50$.

\section{HOTBED CABBAGE PLANTS}

These are grown in hotbeds and are, of course, a bright green looking plant.

Early Flat Dutch Early Jersey Wakefield Succession Large Late Drumhead
Early Summer

Prices, 100 for $40 \mathrm{c} ; 500$ for $\$ 1.75$; parcel post paid. By express, not prepaid, 100 for $30 \mathrm{c} ; 1000$ for $\$ 2.50$.

\section{EGG PLANTS}

Ready in April and up to June.

Black Beauty New York Improved Purple Prices, doz. $30 \mathrm{c} ; 100$ for $\$ 1.25$; parcel post paid. By express, not prepaid, doz. $25 \mathrm{c} ; 100$ for $\$ 1.00$

\section{TOMATO PLANTS} Ready in March and up to Jume. Acme Livingston's Globe Early Detroit Stone Beauty Ponderosa

Prices, Hotbed Stock, or Seedling Plants, doz. $25 \mathrm{c} ; 100$ for $75 \mathrm{c}$, parcel post paid. By express, not prepaid. doz. $15 \mathrm{c} ; 100$ for $50 \mathrm{c}$ 1000 for $\$ 4.50$.

Prices, Transplanted Stock, doz. 35c; 100 for $\$ 1.25$; parcel post paid. By express, not prepaid, doz. $25 \mathrm{c} ; 100$ for $\$ 1.00 ; 1000$ for $\$ 8.50$.

\section{LETTUCE PLANTS}

Ready in March and up to May. Big Boston Large White Cabbage Head Prices, 50 for $35 \mathrm{c} ; 100$ for $60 \mathrm{c}$; parcel post paid By express, not prepaid, 50 for $25 \mathrm{c} ; 100$ for $45 \mathrm{c} ; 1000$ for $\$ 4.00$.

PEPPER PLANTS

Ready in April and up to June.

Chinese Giant, Long Red, Crimson Giant. Prices, doz. 30c; 100 for $\$ 1.25$; parcel post paid. By express, not prepaid. doz. $25 \mathrm{c}: 100$ for $\$ 1.0 \mathrm{n}$.

\section{ASPARAGUS}

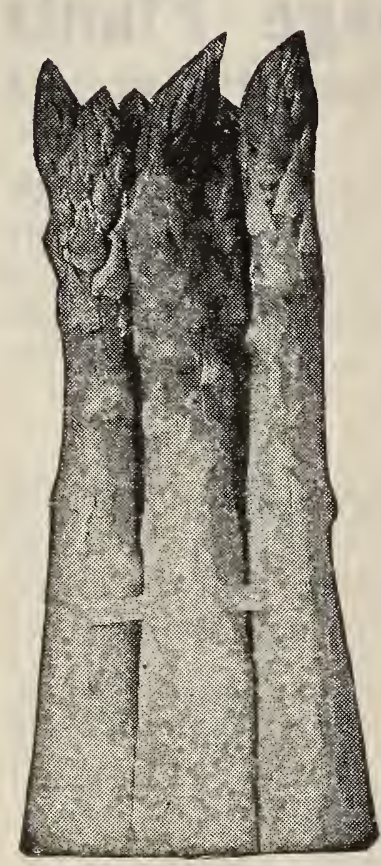

ASPARAGUS

Sow one ounce of seed to 60 feet of drill; sow in early spring in rows one foot apart. When two years old transplant to permanent beds, which should be well and deeply manured and trenched to the depth of two feet. Set the plants in rows from three to four feet apart and two feet in the rows, spreading out the roots and cover from six to eight inches. On the approach of winter cover with manure. Fork the beds early in the spring and apply a dressing of salt. Cut for use second year after planting permanent beds.

\section{A S PAR A G US SEEDS}

CONOVER'S COIOSSAI-The standard variety of larger size, tender and of excellent quality. Pack

PAIMITTO-It is of a very large size, even and regular in growth and appearance. It is a very early Pkt, 5c; oz., -10c; $1 / 4$ lb., $25 \mathrm{c} ; 1$ lb., $75 \mathrm{c}$, postpaid.

COIUMBIAN MAMMOTH WHITE-This excellent variety furnishes shoots of exceptionally large size and of superior tenderness and flavor. The color is clear white until four to six inches above the surface. Pkt. 5c; oz., 10c; 2 oz., 15c; 1/4 lb., 25c; 1 lb., $75 \mathrm{c}$, postpaid.

\section{AS PARAGUS ROOTS}

A year's time can be gained by setting out Asparagus roots, instead of planting seed. A bed of Asparagus, properly made, should last for twenty years or more. The ground should be spaded to a depth of at least two feet and well fertilized. For a small garden, it is desirable to set out the roots in rows two feet apart and 10 to 12 inches between the plants in the low. The roots should be carefully spread out and the crown covered to a depth of about four inches.

Our two-year-old Asparagus roots are heavy, clean stock that will make a vigorous growth the first season.

BONVAIIET'S GIANT-Two-year-old roots. 50 for $65 \mathrm{c} ; 100$ for $\$ 1.00$ COIUMBIAN MAMIMOTH WHITE-Two-year-old roots. 50 for $75 \mathrm{c}$ 100 for $\$ 1.25$.

PAIMETTO-Two-year-old roots. 50 for $65 \mathrm{c} ; 100$ for $\$ 1.00$. CONOVIR'S COLOSSAI-50 for $65 \mathrm{c} ; 100$ for $\$ 1.00$.

By parcel post, add $15 \mathrm{c}$ for 50 , or $25 \mathrm{c}$ for 100 .

\section{ARTICHOKE}

In February or March sow and transplant in hotbed so as to give plenty of room until danger of frost is over. Then set in very rich, well drained soil in rows four feet apart and two feet apart in the row. The plants can be raised in seed beds out of doors, but in that case will not be likely to produce heads the first year. Late in the fall cut off the old tops and thoroughly protect the crowns with leaves or straw to prevent severe freezing.

GREIN GIOBE-The plant of this variety is of medium height with rather deep green leaves. Pkt. 5c; oz., 40c; 2 ozs., $65 \mathrm{c} ; 1 / 4 \mathrm{lb} ., \$ 1.10 ; 1 \mathrm{lb} ., \$ 4.25$, postpaid.

THE JERUSAIEM TUBERS-Excellent for stock and quite often used for table use. peing principal use is for stock feeding, being very valuable for hogs, preventing cholera. They are exceedingly nutritious. feeding, being very valuable for hogs, preventing cholera. They are exceedingly nutritious. They produce an enormous crop. 1 qt. $25 \mathrm{c}$
1 peck $(121 / 2$ lbs. $), \$ 1.00 ; 1$ bushel, $\$ 3.50$.

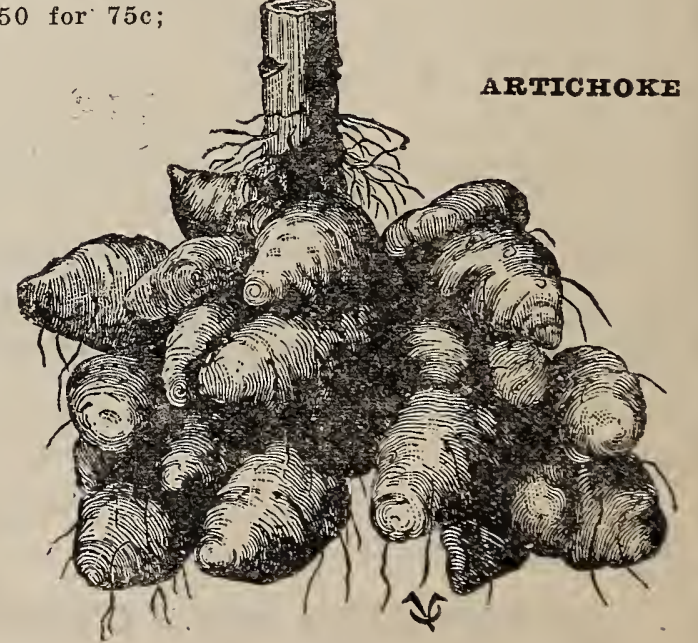



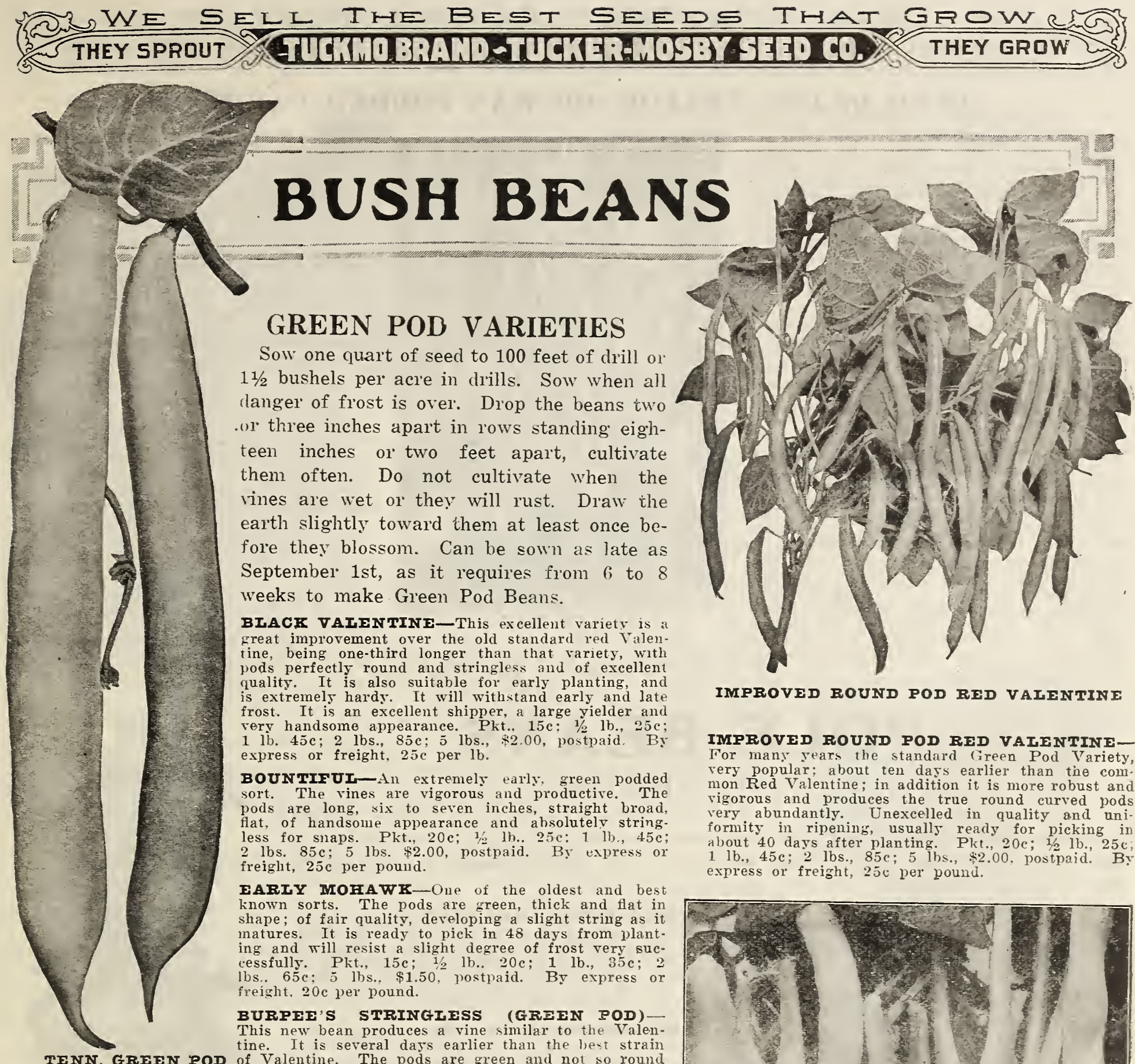

\section{BUSH BEANS \\ GREEN POD VARIETIES}

Sow one quart of seed to 100 feet of drill or $1 \frac{1}{2}$ bushels per acre in drills. Sow when all rlanger of frost is over. Drop the beans two .or three inches apart in rows standing eighteen inches or two feet apart, cultivate them often. Do not cultivate when the vines are wet or they will rust. Draw the earth slightly toward them at least once before they blossom. Can be sown as late as September 1st, as it requires from 6 to 8 weeks to make Green Pod Beans.

BIACK VAIENTINE-This excellent variety is : great improvement over the old standard red Valentine, being one-third longer than that variety, with pods perfectly round and stringless and of excellent quality. It is also suitable for early planting, and is extremely hardy. It will withstand early and late frost. It is an excellent shipper, a large yielder and rery handsome appearance. Pkt., $15 \mathrm{c}$ : $1 / 2$ lb., $25 \mathrm{c}$; 1 lb. 45c; 2 lbs., 85̃ ; 5 lbs., $\$ 2.00$, postpaid. By express or freight, $25 \mathrm{c}$ per $1 \mathrm{~b}$.

BOUNTIFUI-An extremely early; green podded sort. The vines are vigorous and productive. The pods are long, six to seven inches, straight broad, flat, of handsolle appearance and absolutely string. less for snaps. Pkt. 20c: 1/ lh. 25c: 1 lb. $45 \mathrm{c}$ less for snaps. Pkt., $20 \mathrm{c}$; 1/2 lh.. 25c: 1 lb., $45 \mathrm{c}$;
$2 \mathrm{lbs}$. $85 \mathrm{c} ; 5$ lbs. $\$ 2.00$, postpaid. By express or freiglit, $25 \mathrm{c}$ per pound.

EARIY MOHAWK-One of the oldest and best known sorts The pods are oreen, thick and flat in shape: of fair quality, developing a slight striug as it matures. It is ready to pick in 48 days from plant ing and will resist a slight degree of frost very successfully. Pkt., 15c; $1 / 2$ lb.. 20c; 1 lb., 35c; lbs.. 65c; 5 lbs., $\$ 1.50$, postpaid. By express or freight, $20 \mathrm{c}$ per pound.

BURPEE'S STRINGLESS (GREEN POD)This new bean produces a vine similar to the Valentine. It is several days earlier than the best strain TENN. GREEN POD of Valentine. The pods are green and not so round stringless-absolutely so. An the Valentine and less curved. The pods are lb., $45 \mathrm{c} ; 2$ lbs., $85 \mathrm{c} ; 5$ lbs., $\$ 2.00$, postpaid. BY express or freight, $25 \mathrm{c}$ per pound.

GIANT STRINGIESS GREEN POD BEANS-A very hardy, stocky vine; pods round, green in color and of exceptionally fine quality. Stringless throughout the entire length. About a week earlier than the Red Valentine and more By express or freight. $25 \mathrm{c}$ per pound.

IMPROVED DWARF NAVY BEANS-An improvenent ovel the old-time Nary Beans. Plt., 15c; 1/2 lb., 20c; 1 lb., 35c; 2 lbs., 65c; 5 lbs., $\$ 1.50$, postpaid. By express or freight, $20 \mathrm{c}$ per pound.

EARIY REFUGEE-One of the earliest of green pod sorts: very prolific. The pods are thick and fleshy. Pkt., 15c; 1/2 lb., 20c; 1 lb., 35c; 2 lbs., 65e; 5 lbs.. $\$ 1.50$, postpaid. Ey express or freight, $20 \mathrm{c}$ per pound.

TENNFSSEE GRFEN POD-This dwarf snap bean, has for several rears been grown in the South, and wherever known is spoken of in terms of the highest praise. Prolific, foliage dark green; pods long. flat, irregular, bright green and excellent qualit5. Pkt, 20c. $1 / 2$ b 25c $1 \mathrm{~b}$ postpaid. By express or freight, $25 \mathrm{c}$ per pound.

LONGFELIOW-A round-podded green bean of great merit; is entirely stringless and of good flavor. A good bean for early use. Showr and attractive pods. often 6 inches long. Pkt., 20c; $1 / 2$ lb., 25e; 1 lb.,

For our specialties: Tucker's Blue Ribbon Early White corn; Tuck er's Blue Ribbon Early Yellow corn: Tuckmo Delfos corn; Tuckmo Dakota No. 12 alfalfa; and Mosby's Prolific corn. see the pink pages in this catalogue.

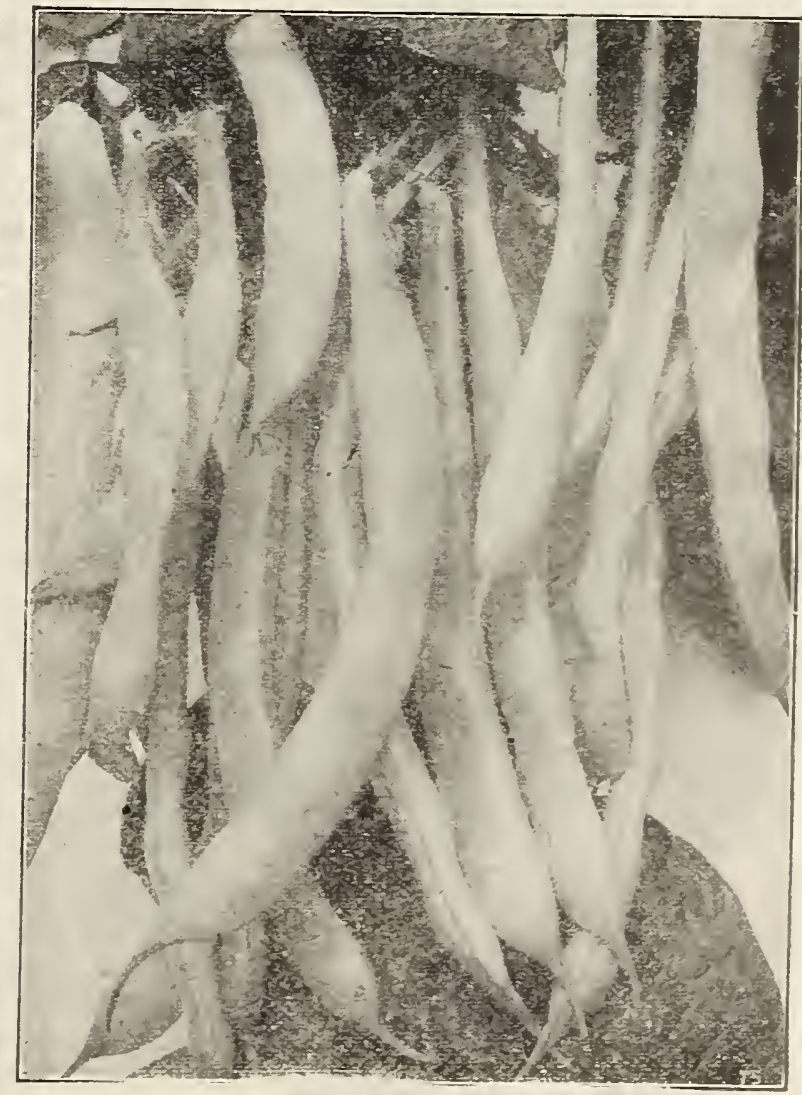

BURPEE'S STRINGLESS GREEN POD 


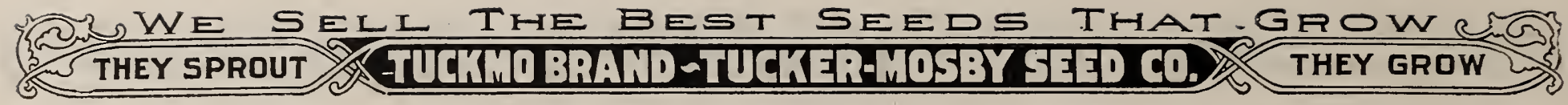

\section{BUSH BEANS-YELLOW OR WAX PODDED VARIETIES}

CRYSTAI WHITE WAX-Distinct but not strictly a wax bean. Vines large, spreading, very productive. Leaves small. Pods greenish white with silver shade, short, about three and one-half inches in length, curved, round or thicker than wide, with crease in the back. very fleshy and brittle. This variety is late maturing and desirable for pickles. Seed very small, oval, white. Pkt., $20 \mathrm{c} ; 1 / 2$ lb., $30 \mathrm{c} ; 1 \mathrm{lb} ., 55 \mathrm{c} ; 2 \mathrm{lbs} ., 95 \mathrm{c} ; 5 \mathrm{lbs}, \$ 2.25$
postpaid. $\mathrm{By}$ express or freight, $30 \mathrm{c}$ per pound.

DWARF BIACK WAX-A very early dwari growing variety, will stand close planting: very prolific; pods medium length, stringless and nearly round, of creamy white color. Seed small, oblong, solid black. Pkt., 15c; $1 / 2$ lb., 25c; 1 lb., 45c; 2 lbs., 85 c; 5 lbs., $\$ 1.90$. postpaid. By express or freight, $25 \mathrm{c}$ per pound.

FIAGOIET WAX BEANS-This variety is of vigorous growth, bearing enormous twisted or curved pods. Measures up fast Seed very large, of dark purplish color. $65 \mathrm{ct},{ }_{5}$ lbs:, $\$ 1.50$, postpaid. $\mathrm{By}$ express or freight, $20 \mathrm{c}$ per pound.

HODSON WAX-The plants of this late maturing variety are exceedingly vigorous, is becoming popular with shippers. While is becoming popular with shippers. While

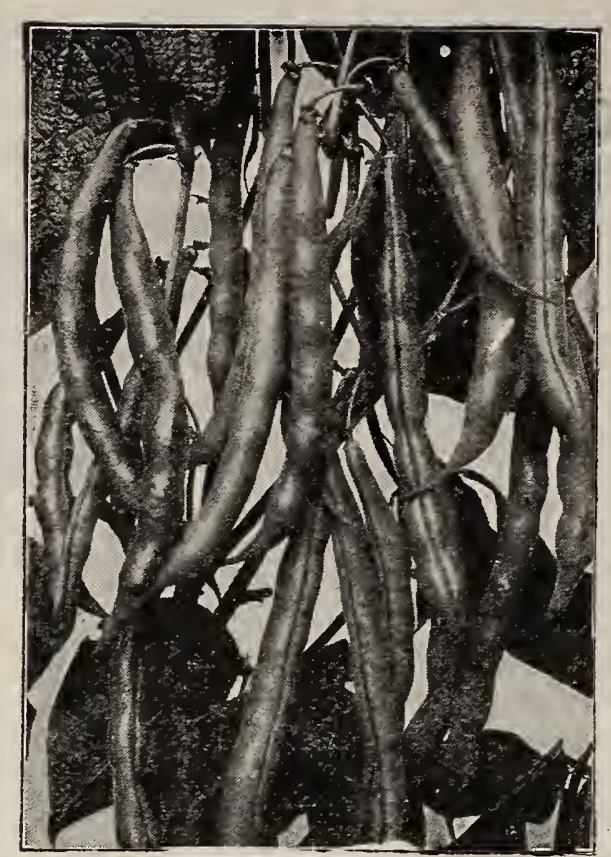

HODSON WAX

DAVIS WHITE WAX-This variety is ex tremely hardy and quite productive. The very early planting. A good shipper. Pod long and tender. Seed long, clear white. Can be used dry for baking. Pkt., 15c; $1 / 2$ lb.

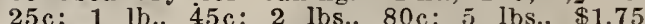
postpaid. By express or freight, $25 \mathrm{c} \mathrm{per} \mathrm{lb.}$ IONG YIIIOW SIX WPFא-Very early and prolific, long yellow, tender, flat pods

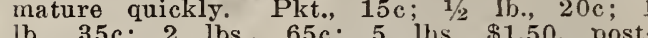
paid. By express or freight, $20 \mathrm{c}$ per pound WARDWRII'S KIDNgY WAX-All ex cellent early variety which for years has been hirhly esteemed by market-growers as the standard of excellence for family trade. It creamy yellow pods average 6 inches long, are broad, decidedly flat but brittle and stringless. Wardwell's Kidney Wax has proven its relia bility under widely varying soil and weathe conditions. Pkt., 15c; $1 / 2$ lb., 20c; 1 ilb., $35 \mathrm{c}$ 2 lbs., 65c; 5 lbs., $\$ 1.50$, postpaid. By ex press or freight, $20 \mathrm{c}$ per pound.

IMPROVID GOIDEN WAX--An inprove ment over the Old Strle Golden Wax: one of the best varieties. Pkt.. 15c: 1/2 lb., $20 \mathrm{c}$ 1 lb., 35c; 2 lbs., 65c: 5 lbs.. $\$ 1.50$, post paid. By express or freight, 20 cents per CURRIE'S RUST PROOF WAX-This variety is very popular with Southern Plant ers. Of vigorous growth and almost entirely

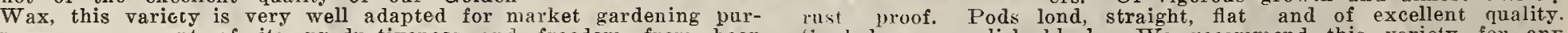

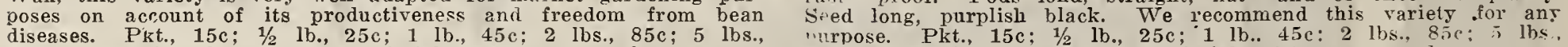
$\$ 1.90$, postpaid. By express or freight, $25 \mathrm{c}$ per pound.

\section{POLE BEANS}

RUNNING VARIETIES

One quart will plant 150 hills. They should have a good, loamy soil. They require more care than the Bush, and should be planted two weeks later, as they stand in much more danger of frost. Plant in hills about three feet apart, dropping 5 to 6 seed to the hill, two inches apart.

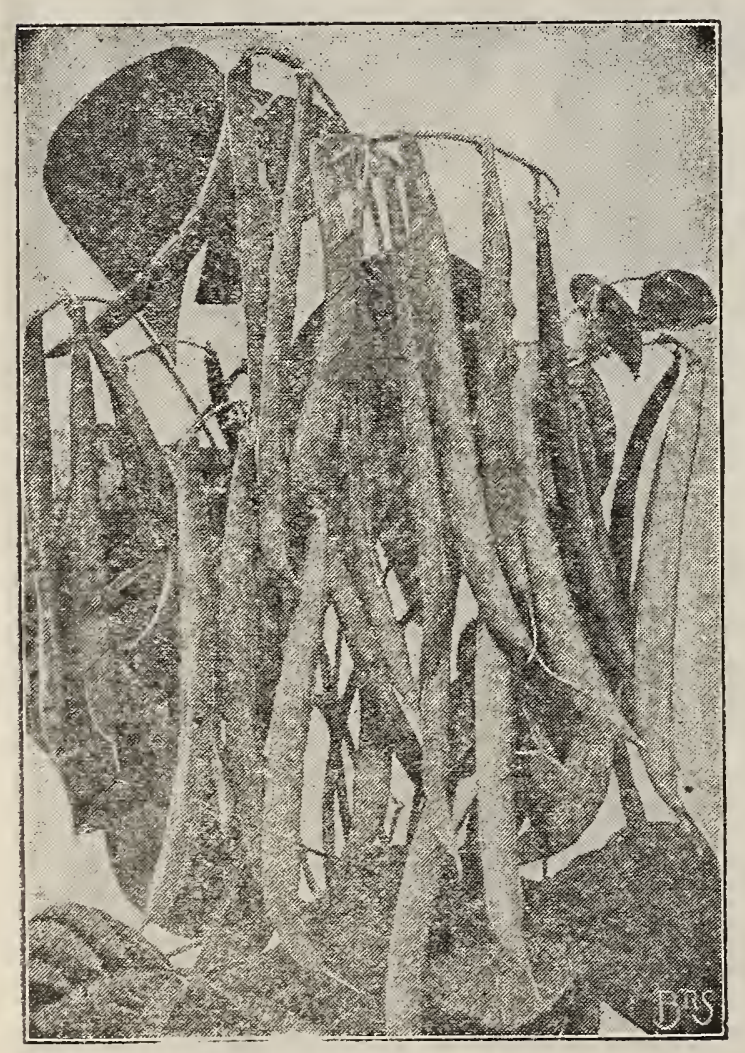

KENTUCKY WONDER

HORTICUTTURAI OR WREN'S IGG-Th
WHITE DUTCH CASP KNIFE-This variety does not make such a vigorous vine. The leaves are large, making a desirable variety for - corn hills. The pods are long and flat, irregular in shape. Pkt., $20 \mathrm{c} ; \quad 1 / 2$ lb., $25 \mathrm{c} ; 1$ lb., $45 \mathrm{c}$; 2 lbs., $85 \mathrm{c} ; 5$ lbs., $\$ 1.90$, postp.
press or freight, $25 \mathrm{c}$ per pound. quality of this bean is excellent, either in the pods young or shell beans, when nearly matured. Leaves are large and of light green color; pods short, containing five or six beans. As the pods grow old they become striped with red. Pkt.

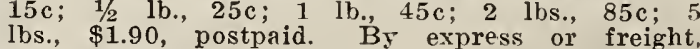
25 c per pound.

NEW SCOTIA OR STRIPFD CREASBACK -It is an extraordinary pole bean, bearing until frost; it makes a handsome green pod, averaging eight to nine beans to the pod. The pods grow very uniform, about six inches long. perfectly stringless, thick meated, rich and buttery; especially adapted for growing with coln. 5 libs., $\$ 2.00$, postpaid. By express or freight. 25 c per pound.

RED SPECKIFD OR CUT SHORT-Th seeds are small and curved, with red spots. On of the best for cornfield planting; prolific. Pod round and short, usually contain about five beans fine growth, medium; leaves are small. Pkt. lbs., \$1.90, postpiad. By express or freight. $25 \mathrm{c}$ per pound.

WHITE CREASBACK-An excellent varlet. for planting in corn. The seed is perfectly white. Pkt., 20c: $1 / 2$ lb., 25c: 1 lb., $45 \mathrm{c}$ 2 lbs., 85c; 5 lbs., $\$ 1.75$, postpaid. BT express or freight, $25 \mathrm{c}$ per pound. freight. $25 \mathrm{c}$ per pound. 


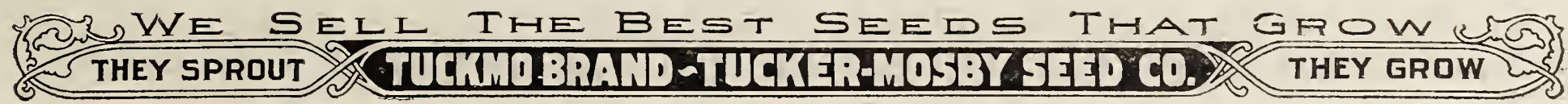

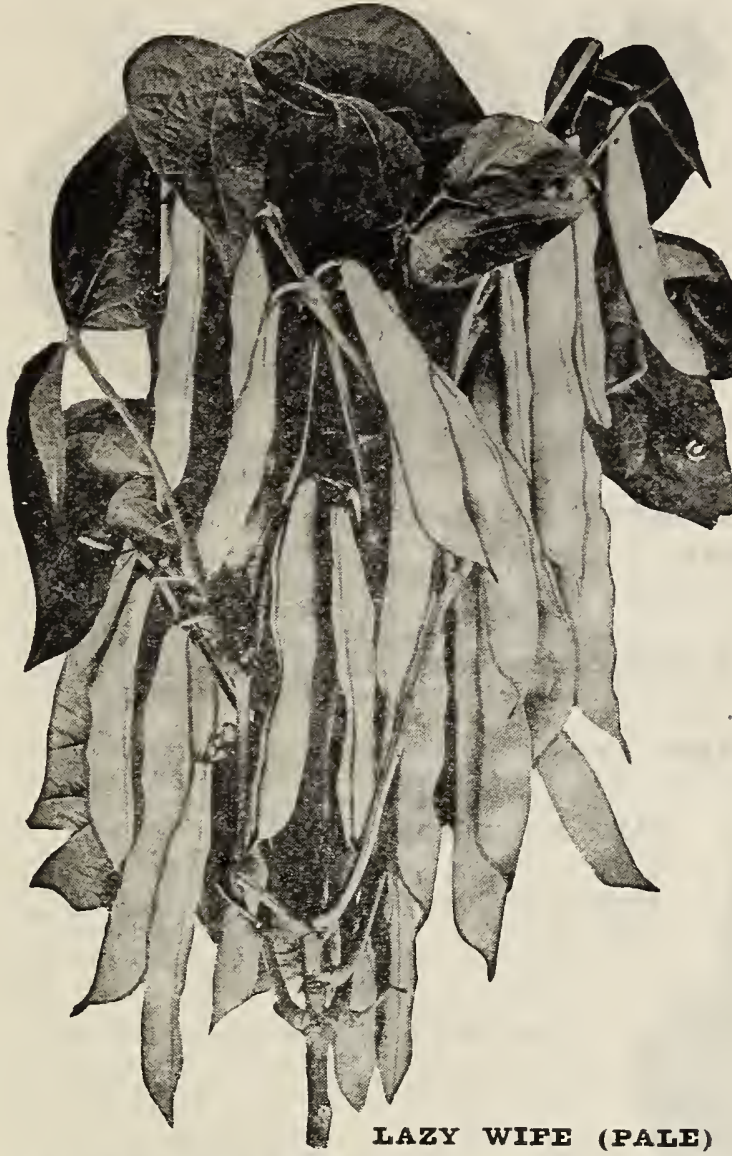

\section{POLE OR RUNNING BEANS-Continued}

LAZY WIFE POIE BEANS-A late variety of excellent quality. Fruits borne in clusters, pods average six inches in length; very fine flavor, round and string. pkt. $20 \mathrm{c}$; $1 / 2 \mathrm{lb} ., 30 \mathrm{c} ; 1 \mathrm{lb} ., 55 \mathrm{c} ; 2$ lbs., $90 \mathrm{c} ; 5 \mathrm{lbs} ., \$ 2.25$, postpaid. By express or freight, $30 \mathrm{c}$ per pount.

KENTUCKY WONDER OR OID HOMESTEAD-We cannot praise this bean too highly. It is one of the best grown, very productive, bearing its long pods in clusters, nearly round, very crisp, tender and of a most superior flavor. Price: pkt., 20c: 1/2 lb., 25c: 1 lb., $45 \mathrm{c}$ : 2 lbs., $85 \mathrm{c} ; 5 \mathrm{lbs} ., \$ 2.00$, postpaid. By express or freight, $25 \mathrm{c}$ per pound.

EARIY GOLDEN CIUSTER WAX-A well known early and very attractive sort. It is one of the hest wax-podded snap pole beans. Price: Per pkt., 20c $1 / \mathrm{lb}, 30 \mathrm{c} ; 1 \mathrm{lb} ., 55 \mathrm{c} ; 2$ lbs., $90 \mathrm{c} ; 5 \mathrm{lbs} ., \$ 2.25$, postpaid. By express or freight $30 \mathrm{c}$ per pound.

SOUTHFRN PROLIFIC-A well known variety, very productive and bears unti frost. Pkt., $20 \mathrm{c} ; 1 / 2 \mathrm{lb} ., 25 \mathrm{c} ; 1$ lb., $45 \mathrm{c} ; 2$ lbs., $85 \mathrm{c} ; 5$ lbs., $\$ 2.00$, postpaid. B express ol freight, $25 \mathrm{c}$ per pound.

\section{LIMA BEANS}

\section{DWARF BUSH BUTTER VARIETIES}

Bush Limas or Butter Beans should be planted three feet apart, ilopping two or three beans every 15 inches in the row.

HENDFRSON'S BUSH IIMA-Grown in compact bush form, producing an enormous crop of delicious lima beans. Is two weeks earlier than any of the Climbin Limas. Produces a continuous erop until frost. Verg productive, delicious flavor. Pkt., $20 \mathrm{c} ; 2 \mathrm{~T} / \mathrm{2}$ lb., $25 \mathrm{c} ; 1 \mathrm{ll}$.
or freight, $25 \mathrm{c}$ per pound.

DREER'S BUSH IIMA-True Bush Lima; the pods are heavy and thick. An immense yielder, growing about $1 \frac{1 / 2}{2}$ feet high. Price: Per pkt., 20c; 1/2 lb., 30c; 1 lb., 55c; 2 lbs., $90 \mathrm{c} ; 5$ lbs., $\$ 2.25$, postpaid. B! freight or express, $30 \mathrm{c}$ per pound.

BURPEE'S BUSH IIMA-This is a bush form of the large Lima Bean; can be successfully grown by anyone. The bushes grow from 18 to 20 inches high of stout growth and always erect. It is an immense vielder. Pkt., 20c; 1/2 lb., 25c; 1 lb., 45c;2 lbs., 85e; 5 lbs., \$2.00, post paid By express or freight, $25 \mathrm{c}$ per pound.

\section{POLE BUTTER VARIETIES}

One quart of seed will plant about 150 hills. They must have a good loamy soil, and not be planted too early, as they will rot in cold, damp soil. Culture the same as other pole beans. Sow about April.

TUCKER'S MAMMOTF BUTTER BEAN-Vines very vigorous and productive. Pods medium dark green, very large, five to six inches long, broad, flat, filled with four or five immense white beans of finest quality. On account of its large pods it is a favorite with market gardeners. It will come into bearing earlier and make larger pods if not more than two vines are allowed to grow on a pole. Seed very large, ovoid, flat, white, with slight greenish tinge. Price: Pel pkt. 15c; 1/2 lb, 25e: 1 lb. 45e; 2 lbs., 85c; 5 lbs. $\$ 1.90$, postpaid. By express or freight, 25e per pound.

CAROIINA OR SIEVA IIMA-The true Southern Butter or Lima Bean. They are small but very prolific and drought resisting. The best running sort for the South Pkt., 15c; $1 / 2$ lb. 20c; 1 lb. 35c: 2 lhs., 65c: 5 lbs.. \$1.75, postpaid. By express or freight, 20 cents per pound.

LARGE WHITE IIMA OR BUTTER BEANS-The standard large pod sort; late; podlarge, beans of good quality. A good drought resister. Pkt., $15 \mathrm{c} ; 1 / 2$ 1b.

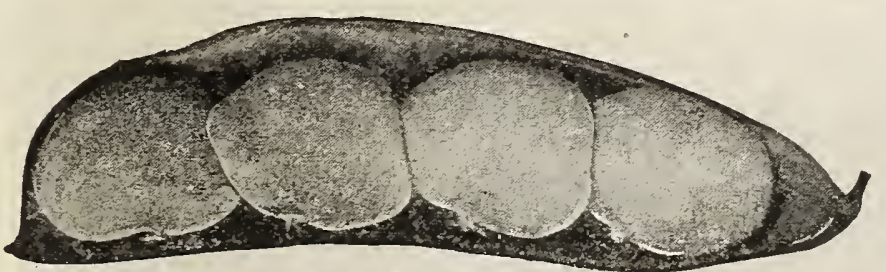

KING OF THE GARDEN IIMA-A very vigorous large pod sort, bearing medium early; the pods contain eight to nine large beans; very prolific. Price: Per pkt $15 \mathrm{c}$ $1 / 2$ ib $20 \mathrm{c} ; \mathrm{lb} 35 \mathrm{c}, 2$ lbs $65 \mathrm{c} ;$; 5 lbs., \$1.75, postpaid. By express $n$ " freight. 20r per pound.

CAROIINA OR SIEVA BEAN

\section{GAR.LIC}

A bulbous-rooted plant with strong, penetrating odor, but much esteemed by some for flavoring soups, stews, etc. We frequently receive orders for garlic seed, but supply the bulbs only. Prepare the ground the same as for onions and plant the bulbs in drills eight inches apart and four inches apart in the rows; cover two inches deep. When the leaves turn yellow, take up the bulbs and dry in the shade and lay them up in the loft as you would onions.

Bulbs, 1/4 lb.. 20c; 1 lb.. 65c, postpaid

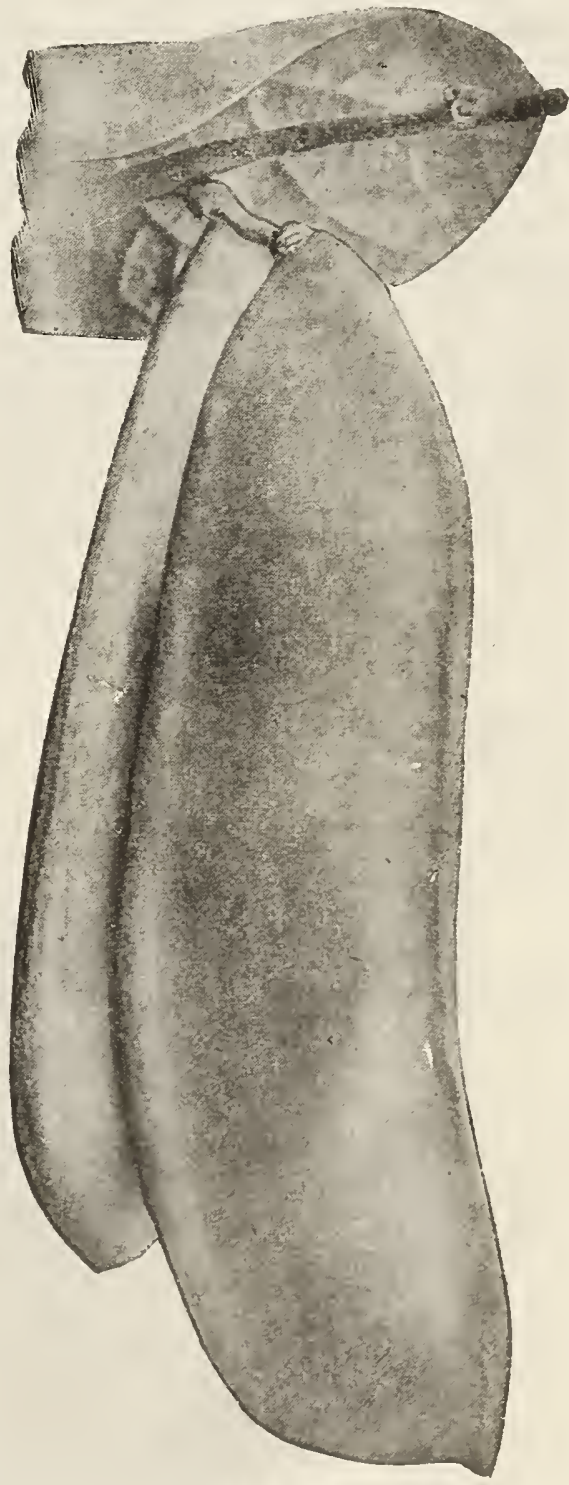

TUCKER'S MAMMOTH BUTTFE BTAN 


\section{TUCKER' BEETS}

\section{TABLE VARIETIES}

Sow in drills from 14 to 18 inches apart, thin to four inches in a row. Beets to produce a good crop should have a loose, loamy soil which has previously been well fertilized and pulverized until a fine seed bed as possible to make has been established. Beets can be sown from February to October in open ground. We recommend open ground culture for the South. One ounce of seed will sow fifty feet of drill, or five or six pounds to the acre.

TUCKMR'S GOIDEN GIOBE-('hoice European variety fully equal and by many considered superior to the red sorts in sweetness and flavor, but both the skin and flesh considered superior to the red sorts in sweetness and fisor, but both the skin and thesh handsome contrast. They mature early and are so sweet and nice that they should become popular. Pkt. $5 \mathrm{c}$; oz., $10 \mathrm{c}$; $1 / 4 \mathrm{lb}, 25 \mathrm{c} ; 1 \mathrm{lb}$. $85 \mathrm{c}$, postpaid.

CROSBY'S IMPROVED EGYPTIAN-Of handsome form and good size, few small tops; rerr small tap roots; fine quality, quick growth; not quite so flat as the ordinary Egyptian or so round as the Eclipse. Looks well even in the early stage of its growth. Pkt. 5c oz., $15 \mathrm{c} ; 1 / \mathrm{t}$ lb., $25 \mathrm{c} ; 1 \mathrm{lb}$., $85 \mathrm{c}$, postpaid.

EXTRA EARIY ECIIPSE-Verr early globe-shaped variety Leaves are medium size; flesh dark crimson in color, having rings of white. Very sweet and close grained. Pkt., $5 \mathrm{c}$; oz., 10c; $1 / \mathrm{llb}$. $25 \mathrm{c} ; 11 \mathrm{l}$., $85 \mathrm{c}$, postpaid.

DETROIT DARK RED-Top small and upright, growing so that the rows may be close together. Roots globe shaped and ery smooth; color of skith a darker shade. Terr crisp and tender. Pkt., $5 \mathrm{c}$; Oz., $10 \mathrm{c}$; $1 / 4$ ib., $25 \mathrm{c} ; 1$ lb., $85 \mathrm{c}$, postpaid.

IONG DARK BIOOD-Sweet, tender and very dark red; good winter keeper stands drought. Plt., $5 \mathrm{c}$ :
$25 \mathrm{c} ; 1 \mathrm{lb}$., $75 \mathrm{c}$, postpaid.

EDMUND'S EARIY BIOOD TURNIP and sweet; keeps well. Pkt., 5c; oz., 10c; $1 / 4$ lb., $25 \mathrm{c} ; 1$ lb. $75 \mathrm{c}$; postpaid.

SWISS CEARD OR SPINACH BEFTThis variety is quite distinct from the edible rooted type of beet. It is grown for its leaf, stems and ribs, which are asparagus. The leaves are cooked after the manner of spinach and make a delightful dish. Probably no vegetable in recent sears has become more popular than the Spinach Beet; a patch should be in every garden. As these plants produce a perpetual supply of leaf stems throughout the petual supply of leat stems throughout the for the average home. Sow in May, in drills 18 inches apart and an inch deep. Thin the plants to 12 inches apart and cultivate the same as for

TUCKER'S BLOOD RED- $\Lambda$ clean. turnip-shaped blood Beet. Skin and flesh are of a deep blood red, sweet and tender in quality and unsurpassed by solidity and keeping purposes. The roots grov regular and are of right marketable size. Tops are small, allowin them to be grown close together. They mature early and give every satisfaction as a hunching sort. Plkt., 5c; oz., 10c; 1/1 1b., 25c; lb. $85 \mathrm{c}$, postpaid.

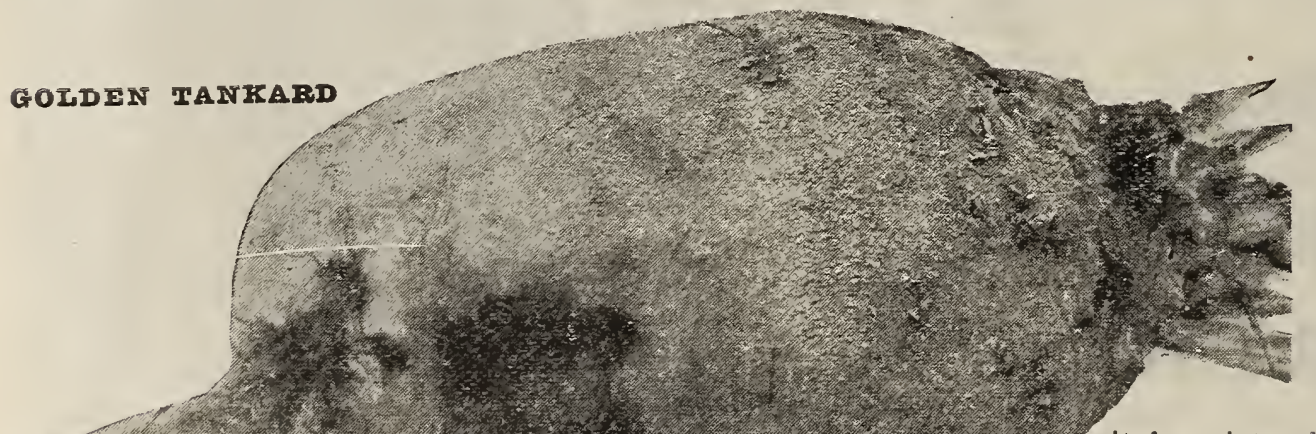

CRIMSON GIOBE-A medium early. Tops small; flesh rich crimsoin. It is excedingly rich and almost smooth and slick. The most desirable sort of small beets for early market. Pkt., 5c; oz., 10c; 1/4 lb., 25c; 1 lb., $85 \mathrm{c}$, postpaid. EXTRA EARIY DARK RED EGYPTIAN-One of the earliest. Dark blood color, small top; fine forcer; tender and sweet. Pkt., 5c $0 z$. 10c; $1 / 4$ lb., 25c; 1 lb., $75 \mathrm{c}$, postpaid.

EARIY BASSANO-Shape resembles the Early Egyptian; flesh white, circled with a bright pink; fine flavor. Pkt., 5c; oz., 10c;

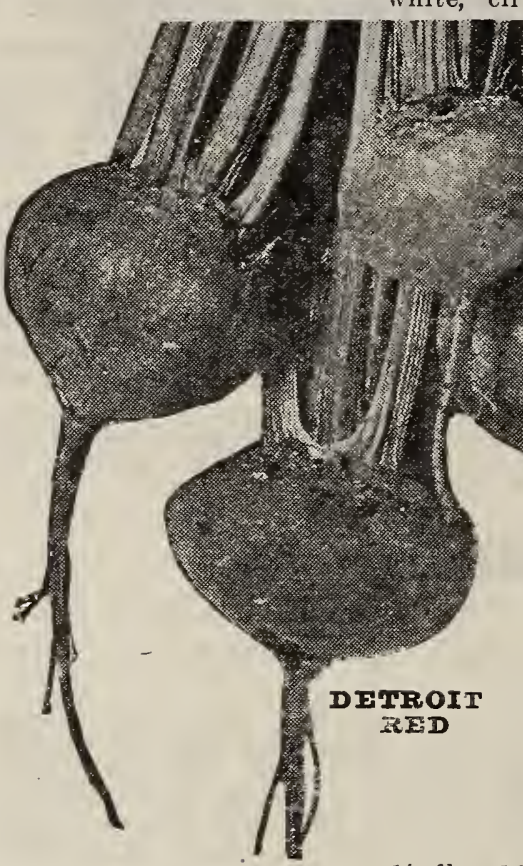

HAIF IONG BEFTS-This sort is similar to the long in quality, but is only half long. Pkt. $5 \mathrm{c}$ : 0z. $15 \mathrm{c} ; \mathrm{z} / \mathrm{lb}, 35 \mathrm{c} ; 1 \mathrm{lb}$. $\$ 1.00$, postpaid IMPROVED TURNIP $11 \mathrm{c}$ (b. $\$ 1.00$, postpaid. Turnip has always been considered the standard for general use. This special strain is the refor general use. This special strain is the reover a number of years, until we are now satisfied that there is no chance for further inprovement-in short, that it is perfect in every desirable quality. Developed from a choice strain of the Early Blood Turnip it is much earlier in maturing and greatly surpasses that variety in flavor. It is perfectly globular in shape and of the largest ize. Tops are small and of uniform rowth. The flesh is fine grained, of rich, deep, blood-red color, which is retained when cooked, and is always vert sweet and tender. In excellent keeper. Pkt., $5 \mathrm{c} ;$ or., $10 \mathrm{c} ; 1 /, 1\}$ $25 \mathrm{c}$; 1 lb., $85 \mathrm{c}$, postpaid.

\section{SUGAR VARIETIES}

Sow and cultivate same as Mangel Wurtzel.

LANE'S IMPROVED-An ex cellent white sugar variety, ery productive; small leaves, a good keeper. Pkt., 5c oz., 10c; $1 / 4 \mathrm{lb}, 35 \mathrm{c} ; 1 \mathrm{lb}, 60 \mathrm{c}$; postpaid. By freight per pound.

FRENCF RED TOP-Early, rich in percentage of sugar; large yielder per acre. Pkt., $5 \mathrm{c}$; oz., $10 \mathrm{c} ; 1 / 4 \mathrm{lb} ., 20 \mathrm{c}$; 1b., 20c; 1 lb., 60c; postpaid. By freight, 50c per pound.

KIEN WANZEIBEN-The standard sugar producing variety: an enormons rielder, Contains 18 per cent sugar. Pkt., 5c; oz.. 10c lb., 60c; postpaid. Bv freight, $50 \mathrm{c}$ per pound.

\section{MANGEL WURTZEL FOR STOCK FEEDING}

Sow five pounds to the acre in the Spring, in drills two feet apart and when three inches high thin out in rows to eight inches apart. Soak the seed twenty-four hours before sowing and sow when the ground is moist. Long varieties are suited best to deep rich soil. The Tankard varieties succeen better than the long on thin and sandy soil.

MAMMOTH LONG RED-Very select. enormous producer for deep soils. Fine feèd for horses and cattle or sheep. Exceedingly nutritious and healthy feed. Nothing will beat it for winter feed. Pkt. 5c; oz. 10c: 1/ 1b. 15c; $11 \mathrm{lb}, 50 \mathrm{c}$ postpaid. By freight, $40 \mathrm{c}$ per pound.

GOIDEN TANKARD-Remarkably even in shape, rathe elongated, of vigorous growth, and a ver'y smooth skin. fles quite rellow, firm and sweet. Much liked by cattle. lifted from the ground. Produces an enol'un lent keeper. Pkt., $5 \mathrm{c}$; oz. $10 \mathrm{c}$; $1 / 1$ lb. $15 \mathrm{c} ; 1 \mathrm{lb} . .50 \mathrm{c}$, postpaid lent freight, $40 \mathrm{c}$ per pound. 


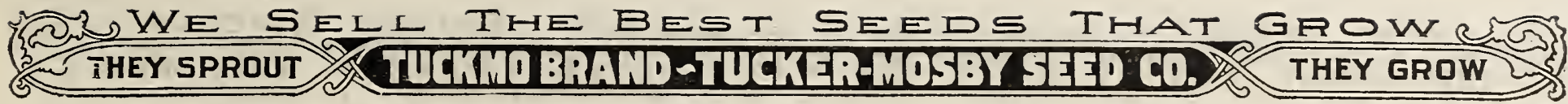

\section{RELIABLE CABBAGE SEED}

Cabbage is more largely grown for market than any other vegetable excepting the potato. All growers recognize the importance of planting only the finest seed. We offer only the best seed that is possible to raise. Seed that may be depended upon and with proper care gives excellent results. One ounce of seed will produce about 2,500 plants; four ounces of seed will grow enough plants to set out an acre.

CHARIESTON WAKEFIERD-A selection from the Early Jersey Wakefield about one week later; grows much larger head; very popular in the South, Pkt., 5c; oz., 20c; $1 / 4$ lb., 50c; 1 lb., $\$ 1.75$, postpaid.

FARLY WINNINGSTADT-The old standard variety. In season very chose to the Early Jersey Wakefield; head large, decidedly conical. A very sure header. Pkt., 5c; oz., 20c: $1 / 4$ lb., 50c; 1 lb., $\$ 1.75$.

TUCKER'S EARIY MARKET-One of the earliest main crop cabbages of superior quality. Very desirable where a large, uniformly round head with short stem and compact growth is wanted. Matures very early for such large heads of excellent shape. It is also exceptionally hardy. Pkt., 5c;0z., 25c;2 oz. $40 \mathrm{c} ; 1 / \mathrm{l} \quad 1 \mathrm{~b} ., 75 \mathrm{c} ; 1 \mathrm{lb} ., \$ 2.50$.

TUCKER'S FROST PROOF CABBAGE-The hardiest of any cabbage grown has a short stem and makes a deep blue and wide leaf, making a broad, flat head, all very uniform in size. Pkt., $5 \mathrm{c} ; 1$ oz., $25 \mathrm{c} ; 1 / 41 \mathrm{~b} ., 75 \mathrm{c} ; 1 \mathrm{lb}$. $\$ 2.50$, postpaid.

MAMIMOTH ROCK RFD-The largest and surest heading red cabbage, much better than stock offered as Red Drumhead. Plant large, with numerons spread. ing leaves; stem of medium length. The head is large, wound, very solid and of very attractive deep red color. Pkt.. $5 \mathrm{c} ; 0 \mathrm{z} ., 25 \mathrm{c} ; 1 / 4 \mathrm{~b} ., 75 \mathrm{c} ; 1 \mathrm{lb} ., \$ 2.50$,

pREMIUIM IATE FIAT DUTCF-This variety never fails to give entire satisfaction to the grower, is uniform and producing head of immense size and usually very solid. Pkt., 5c; oz., $20 \mathrm{c} ; 1 / 1 \mathrm{lb}$., $50 \mathrm{c} ; 1 \mathrm{lb} ., \$ 1.75$.

SOIID SOUTH-Similar to Early Summer, but is earlier and larger: more uniform, having fewer outside leaves. Pkt., 5c; oz., coc; $1 / 1 \mathrm{lb} .50 \mathrm{c} ; 1$ lb., $\$ 1.75$

DANISH, BAII HEAD-Very hardy, handsome, very solid, of fine quality and as one of the very best keepers it is particularly desirable for distant markets or for late spring use. The plan is vigorous, compact growing, with stem of medium length, and exceedingly hardy in resisting cold and dry weather. The leave are few, but rather large, thick, smooth, bluish green, covere with whitish bloom. The head is medium sized, round, ver solid and stands shipment better than any other late sort. W offer seed of our own growing which, judging from recent trials, solid head variety. This we consider best to follow the Wakefield. It is about ten days later. Pkt., $5 \mathrm{c} ; 0 \mathrm{z} ., 20 \mathrm{c} ; 1 / \mathrm{llb} ., 50 \mathrm{c}: 1 \mathrm{lb}$. $\$ 1.75$, postpaid.

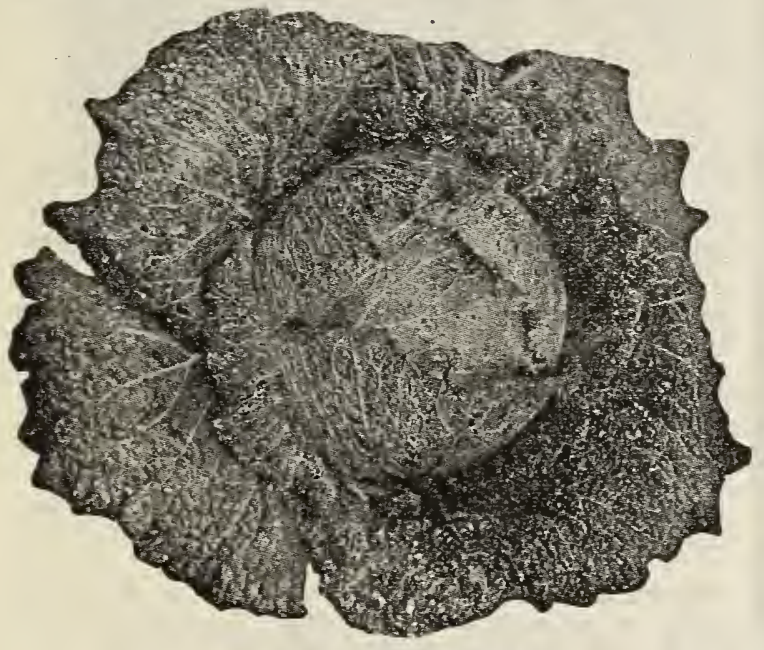
will produce more uniformly typical heads than can be grown from the best stock obtainable elsewhere. Pkt., 5c; oz., $25 \mathrm{c} ; 1 / 1 \mathrm{lb} ., 75 \mathrm{c} ; 1 \mathrm{lb} ., \$ 2.50$, postpaid. EARIY SPRING-This is a first class extra early round, fiat head cabbage. The heads are always uniform in

SUCCESSION-Superior second

very evenly. Pkt., $5 \mathrm{c}$; oz., $20 \mathrm{c}: 1 / 1 \mathrm{lb} ., 50 \mathrm{c} ; 1 \mathrm{lb}$., $\$ 1.75$, postpaid.

HENDERSON'S EARIY SUMMER--Second early and large; matures abou ten dats later than the Wakefield.

th. $60 \mathrm{c}$ : 1 lib.

EARIY JERSEY WAKEFIEID-One of the very best early cabbages in culti ration. Grown extensively for market and shipping: large heads for an earl sort. Very solid. Pkt., 5c; oz., 20c; 1/4 lb., 50c; $1 \mathrm{lb}$.. \$1.75, postpaid.

IARGE DRUMFEAD-Our strain of this variety cannot be surpassed

recommend this for late marke

AII HEADS EARIY-A thoroughbred sort of remarkable uniform size and shape, sure heading. Deep flat heads, solid and uniform in color; tenderness unsurpassed; grows compactly; yields more heads per acre than many other Pkt., $5 \mathrm{c}$; 0z. 20c; $1 / 1$ lb., 60c; $1 \mathrm{lb}, \$ 2.00$.

T. MI. S. Co.'S FARIY FIAT DUTCH-This is just the cabbage for your garden, producing full solid, good sized heads. Fit for use from 70 to 80 days from sowing. Heads being remarkably solid and most uniform in shape and size

EARIY SUMMER

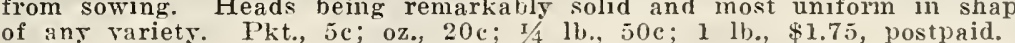

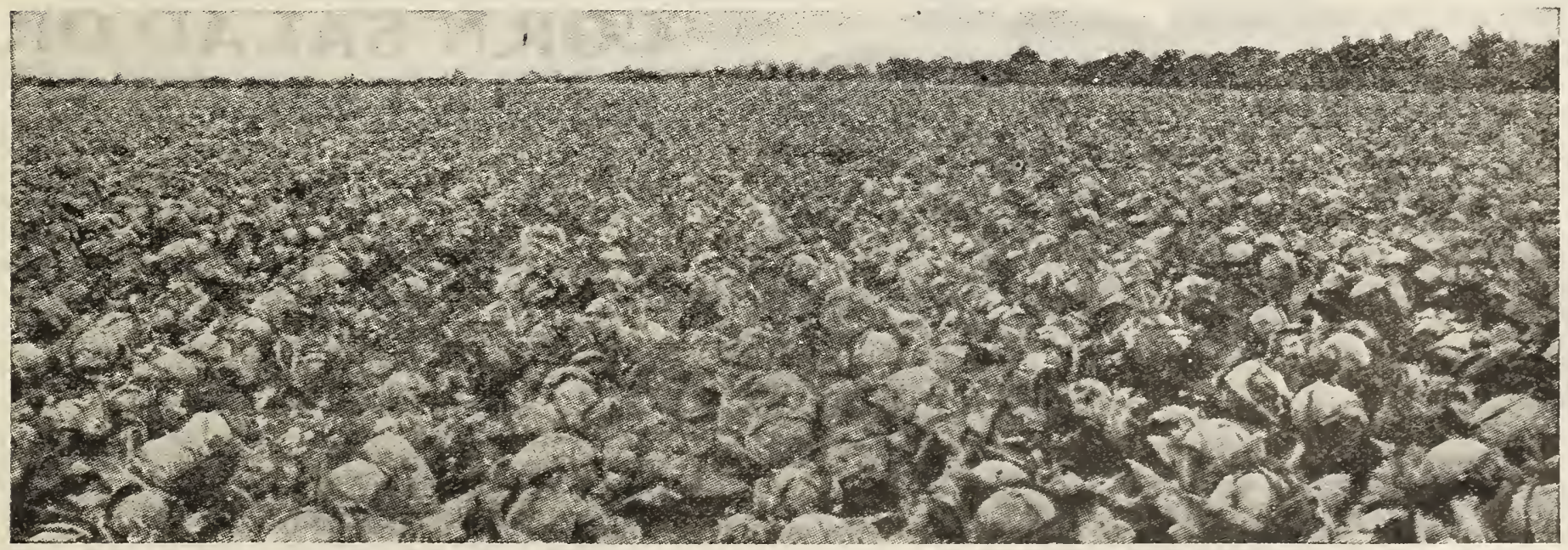

A FIELD OF EARLY FIAT DUTCH GROWN FROM TUCKMO BRAND SEFD 


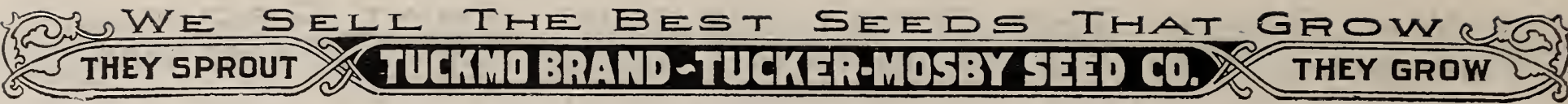

\section{RELIABLE CABBAGE SEEDS-Continued}

FARIY FURFKA-Very hardy, round heading sort; extra early, coming into use as early as the Wakefield. Pkt., 5c

IARGE PARIY YORK-Similar to Early York, only heads are larger; good for early market. Pkt., $5 \mathrm{c} ; 0 \% ., 20 \mathrm{c} ; 1 / 4$ lb., $50 \mathrm{c} ; 1 \mathrm{lb} ., \$ 1.75$, postpaid.

IARGP DRUMHPAD SAVOY-A superior, large headed fall and winter sort, finely curled; qualified extra fine. Pkt., 5c; oz., 20c; 1/4 lb., $60 \mathrm{c} ; 1$ lb., $\$ 1.75$, postpaid.

FOTTIFR'S FARIY DRUMHFAD, OR BRUNSWICK SHORT STMM-One of the very best second early sorts, especially for the home garden. The plant is of dwarf compact growth, with very short stem and few outer leaves. The head is large, flat, solid and of excellent quality. Most desirable as an intermediate variety and also well adapted for late use. We have taken pains to have our stock free from the long stemmed, coarse plants often seen in in. erior stocks of this variety. Pkt.,

Ib. 60c; $1 \mathrm{lb}, \$ 2.00$, postpaid.

GIORY OF PNIKUTZEN-A comparatively new second early variety, very sure heading and of excellent quality. Plant of vigorous growth, with large rather spreading outer leaves which are noticeably curved and frilled. Head globular or very nearly round, very solid and of large

a for so early a variety. Plat., $50 ; 0 \%, 25 c$

\section{CHINESE OR CELERY CABBAGE}

PF-TSAI_-This veretable is called Pe-Tsai, or Cut Cabbage, by the Chinese gardeners, and is beginning to attract attention in America. It does not form a cabbagehead, but when grown to its full size resembles the Cos Lettuce, and the outer leaves ma be used during its growth. The flavor is mild, and it is used either as a salad or cooked. The plants require plenty of room, and should be set in rows 2 to 3 feet apart and 15 inches apart in the row. ngs run to

\section{BRUSSELS SPROUTS}

A species of the cabbage family which produces miniature heads from the side of the stalk. These heads are a great delicacy hoiled in the same way as cauliflower. The
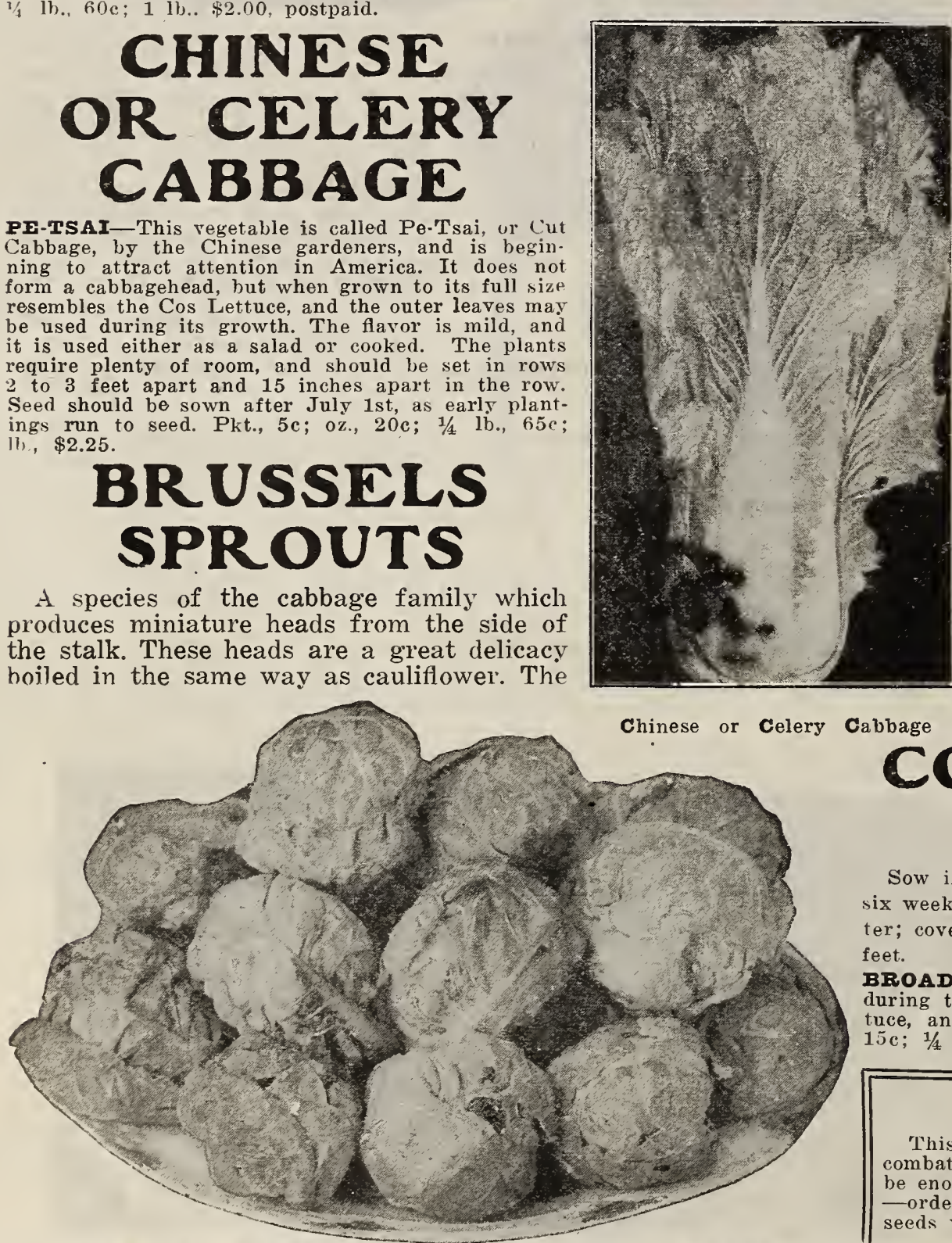

seed should be sown about the middle of May in a seed bed and the plants afterwards set out in rows two feet or more apart and cultivated like cabbage. It is ready for use-late-in autumn, after early frost.

IMPROVED DWARF-Produces compact syrouts of the finest quality. A good keeper. Pkt. $5 \mathrm{C}$. oz., 20; 1 lb., $\$ 1.50$, postpaid.

\section{CRESS}

As early in spring as the ground can be worked, sow the seed in rich, well prepared soil, in shallow drills about sixteen inches apart, covering with about one-half inch of fine soil firmly pressed down. When the young plants are well started thin four to six inches apart in the row. For succession plant every two weeks, thinning out as required for use. Keep off insects by dusting with Bug Death.

CURIFD OR PEPPER GRASS-For salads and garnishing. Leaves are pungent. Pkt., $5 \mathrm{c}$ : oz. 10c; $1 / 4$ lb., $20 \mathrm{c} ; 1 \mathrm{lb}$., $65 \mathrm{c}$, postpaid.

WATrR CRFSS-Scatter the seed on a mudd: bank of an everrunning stream. It is one of the most delicious of small salads.
$75 \mathrm{c} ; 1 / 4 \mathrm{lb} . . \$ 1.25 ; 1 \mathrm{lb}, \quad \$ 4.50$.

\section{CORN SALAD OR FETTICUS}

Sow in spring, in drills one foot apart. It will mature in six weeks. For early spring use, sow in September and win ter; cover like spinach. One ounce will sow about 18 square

BROAD-IrAVED (Large Seeded)-A delicious salad, used during the winter and spring months as a substitute for lettuce, and also cooked and used like spinach. Pkt., 5c; oz. $15 \mathrm{c} ; 1 / 4 \mathrm{lb} ., 35 \mathrm{c} ; 1$ lb. $\$ 1.00$.

ORDIR YOUR SFED FARIY

This year hundreds of new gardens will be planted to combat the high cost of living and the demand for seed wil be enormous, so don't wait until stocks have been sold out order your seed today. With our vast supply of pure seeds we can fill all early orders promptly. 


\section{CARROTS}

The Carrot is one of the most wholesome and nutritious of our garden roots, deserving to be more extensively used for culinary purposes, and we urge our customers to give some of the early table varieties as well as feeding sorts a trial. For horses and especially as winter feed for milch cows, the Carrot cannot be surpassed, and it should be more largely grown by farmers for this purpose.

While a sandy loam, made rich by manuring the previous year, is the best soil for the carrot, any good land, if thoroughly and deeply worked will produce satisfactory crops. It is advisable to sow as early in the Spring as the ground is fit to work, though good crops may be grown from sowings as late as June 15. For table use sow the smaller kinds in rows sixteen to eighteen inches apart. For field culture sow in drills eighteen to twenty-four inches apart, using from one and onehalf to three pounds of seed to the acre. Cover one-half to one inch deep, and see to it that the soil is pressed firmly above the seed. As soon as the plants appear, use the cultivator or wheel hoe. Thin to six inches apart in the row.

HAIF LONG SCARIET NANTES, STUMP ROOTED-This excessively used, half long, early variety has small tops and is excellent for the marke or home garden. The roots are cylindrical, smooth and of a bright orange color. The flesh is orange, becoming yellow in center, but very tender

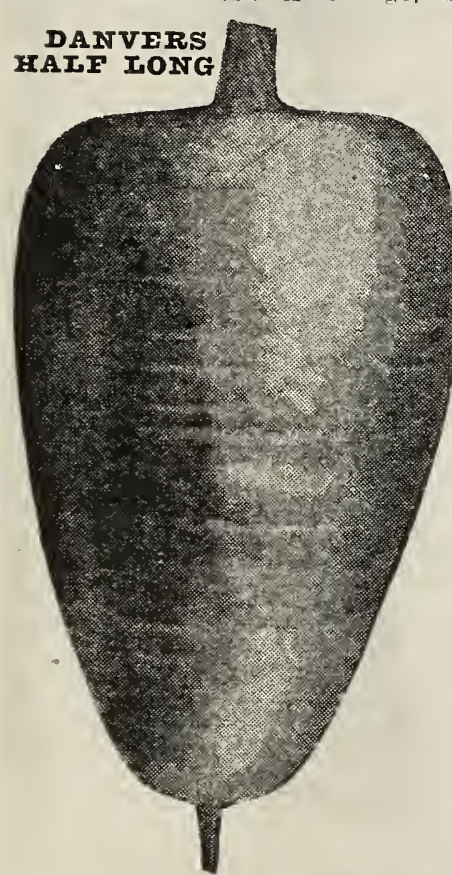
throughout. This variety is of the finest
quality and is one of the most symmetrical and handsome of the medium sized sorts. The mature roots are usually five or six inches lonk. Pkt. $5 \mathrm{c} ; 0 z ., 10 \mathrm{c} ; 2$ oz., $15 \mathrm{c} ; 1 / 1$ lb., $25 \mathrm{c} ; 1 \mathrm{lb} ., 85 \mathrm{c}$; postpaid.

DANYFR'S FAIF IONG-The best for general crop. Will yield the most per acre. Most profitable for market gardeners, stump rooted, smooth and handsolne. Flesh swept, crisp and tender. Pkt., 5e \%.. 10c; I/4 lb., 25c; 1 lb., 85c, postpaid.

TUCKER'S IMPROVED IONG ORANGE-This is a decided improvement obtained by years of care ful selection of the best formed and deepest colored roots of the old Long Orange which was the most popular of the older sorts for farm use on deep and mellow soil. Suitable for table use as well as stock feeding, combining greatest productiveness with uniform shape. When of size suitable for the table, the roots are tender and of good quality. Packet $5 \mathrm{c} ; 0 \mathrm{z} ., 10 \mathrm{c} ; 2$ ozs., 15c; 1/4 lb., 20c; 1 lb., $75 \mathrm{c}$, postpaid OXHART OR GUFRANDE-Most valuable, variety in existence. Intermediate between Half Long and Horn sorts; diameter 3 to 4 inches at neck; beauiiful shape; rich orange color. Easily pulled, early as any. best quality all season. Fine for stock; has yielder, 1,200 bushels per acre. (vit tops with scrthe; pull with potato hooks. Pkt., $5 \mathrm{c} ; 0 z ., 10 \mathrm{c} ; 1 / 1$ 1b., $25 \mathrm{c} ; 1 \mathrm{lb} ., 85 \mathrm{c}$, postraid.

WIITz BITGIAN-Carge, white rooted, with green tops; fine quality, grown exclusively for stock Pkt., 5c; oz., 10c; 1/4 lb., 25c; 1 lb., $85 \mathrm{c}$, postpaid.

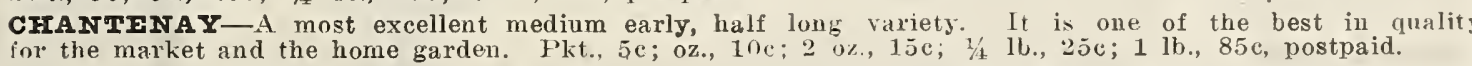

\section{CHERVIL}

Used for flavoring or garnishing, and is more beautiful than parsley. Sow in early spring in rich soil, and when the plants are large enough, transplant to rows about one foot apart.

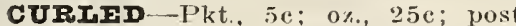
paid.

\section{CAULIFLOWER}

One-half ounce of seed will produce about 500 plants; three ounces make enough to set out an acre. For early forcing sow in December, or for Spring planting, sow in January or February in gentle hot beds or cold frames; for field culture, sow and give the same treatment as for Early and Late Cabbage. They require plenty of manure and good culture. After they begin to head, fasten the leaves together over the tops, so as to protect from the sun and keep white.

TUCKER'S EARIY SNOWBAII-The best variety for general use Of dwarf habit, and produces fine, white heads in a very short time. Al ways tender and sweet; an excellent sort for either spring or fall planting. Our seed is grown in December in Denmark by a specialist and cannot be surpassed. Pkt., 15c; $1 / 4$ oz., $50 \mathrm{c} ; 1$ oz., $\$ 1.75$, postpaid.

FXTRA FARIY DWARF ERPURT-A remarkably sure heading early Cauliflower. It is of dwarf habit with short outside leaves and is similar in all respects to Early Snowball, and nearly as early. The heads when ready for market are of medium to large size. Pkt. 15c; i/1oz. 50c; oz, $\$ 1.75$. TUCKER'S GIANT DRY WEATHER CAUIIFIOWER-This splel did new Cauliflower will succeed and make fine crops in the dryest kind of weather when other varieties fail. It produces large, solid, pure whit

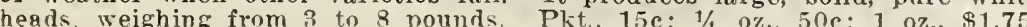

\section{COLLARDS}

A plant of the cabbage family. It is extensively grown in the South, as it endures the extreme heat.

TRUE SOUTHERN-P

$25 \mathrm{c} ; 1$ lb., $75 \mathrm{c}$, postpaid.

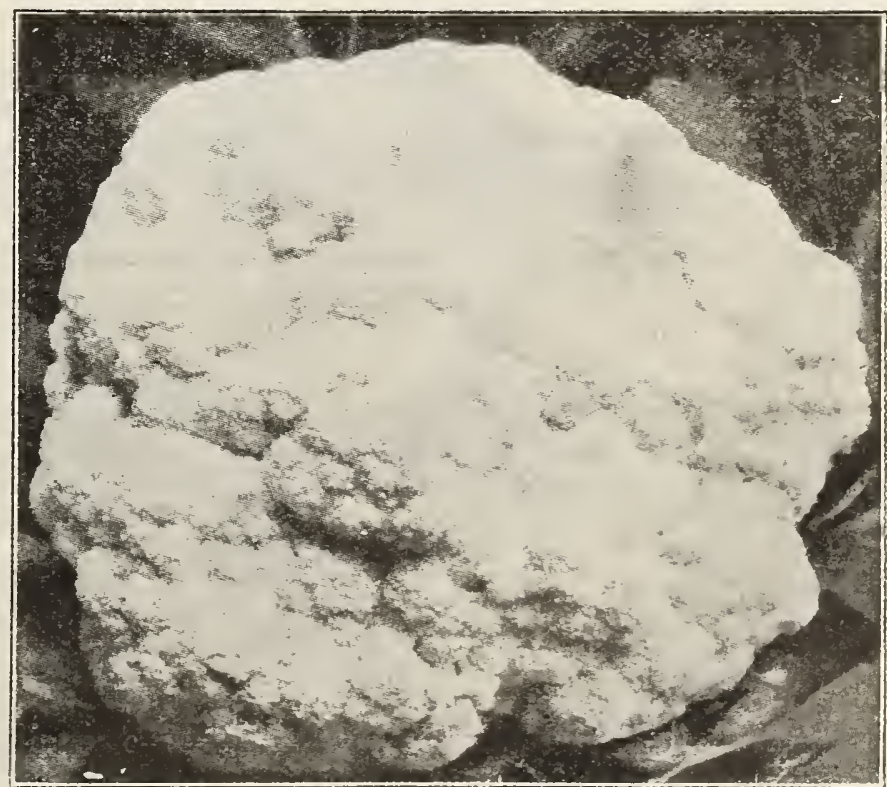

TUCKER'S EARLY SNOWBAII 


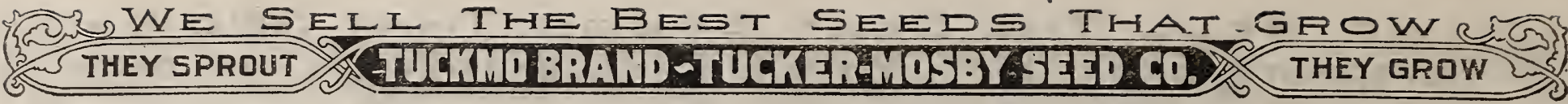

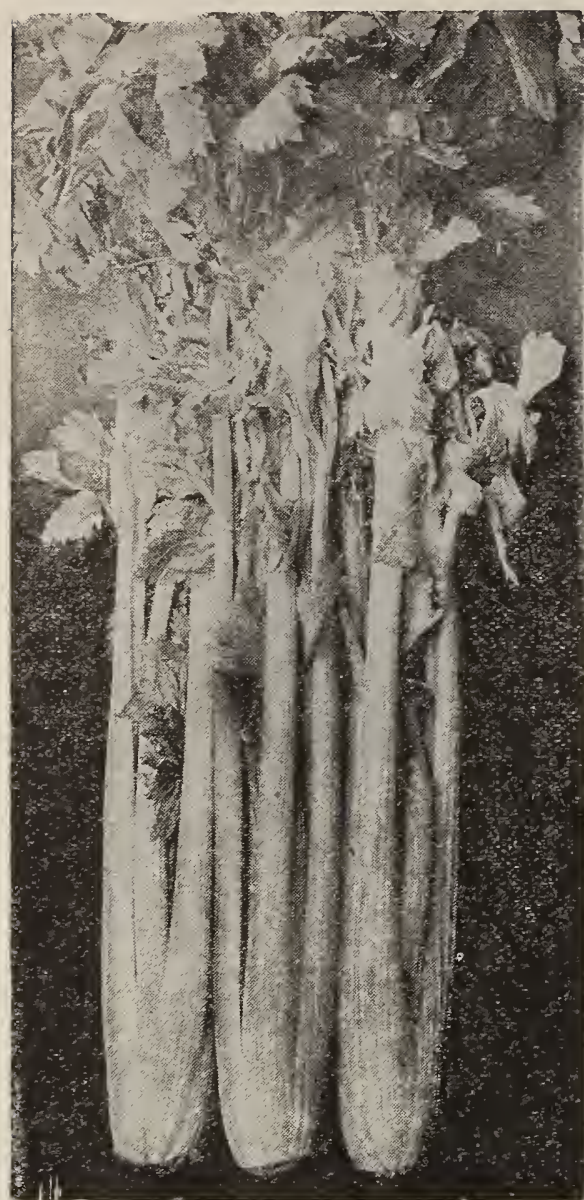

GOIDEN PUUME

\section{CELERY}

One ounce of seed will produce about thiee thousand plants. Celery can be successfully grown with little labor in any good garden soil. Use plenty of manure or high gracle fertilizer; it delights, however, in low moist bottom land or welldrained muck land. It is usually grown as a second crop.

GIANT PASCAI-Broad, thick, solid, cream-colored stalks of handsome appearance which are entirely stringless, crisp and tender. Plkt.. $5 \mathrm{c} ;$ oz., $25 \mathrm{c} ; \mathrm{I} / 4 \mathrm{lb}, 60 \mathrm{c} ; 1 \mathrm{lb}, \$ 2.00$, postpaid

WHITE PLUNE-The most desirable variety for home and market use. A good self-blanching sort. Pkt., 5c; oz., $20 \mathrm{c}$; $1 / 4 \mathrm{lb}$., $60 \mathrm{c} ; 1 \mathrm{lb}$., $\$ 2.00$, postpaid.

GOIDIN SFIF-BLANCFING-The best self-blanching sort. Plants medium size and make a stocky growth; heart is rich golden-yellow, with light yellowish-green outer leaves. The quality excellent, as the stalks are remarkably crisp and tender. Pkt., $5 \mathrm{c} ; 0 \mathrm{z} . .35 \mathrm{c} ; 1 / 1 \mathrm{lb} ., \$ 1.00 ; 1 \mathrm{lb}$., $\$ 3.75$, postpaid.

NEW COIUMBIA-An early maturing sort, unsurpassed in shape and quality. The plant is of medium height, but very stocky and heavy. Pkt., $5 \mathrm{c} ; 0 \mathrm{z} ., 25 \mathrm{c} ; 1 / 4 \mathrm{lb} ., 75 \mathrm{c} ; 1 \mathrm{lb} ., \$ 2.75$, postpaid. CEIERIAC OR TURNIP-ROOTID CEIFRY-Produces large turnip-like roots which keep well for winter use. Ready for use in October. One ounce for 50 feet of row.

IARGE SMOOIF PRAGUE-An excellent variety and desirable for answering all requirements. Pkt., $5 \mathrm{c} ; 0 \mathrm{z} ., 15 \mathrm{c} ; 1 / 1 \mathrm{l}$ lb., $60 \mathrm{c} ; 1 \mathrm{lb}$., $\$ 2.00$, postpaid.

\section{SWEET AND GARDEN CORN}

Plant as soon as the ground becomes warm in the spring. One quart will plant about two hundred hills; one peck will plant about an acre in hills. Plant in hills three feet apart, four or five grains to the hill, and when up thin out. For succession plant every ten days.

Do not plant sweet corn close to pop corn or field corn or they will mix.

EXTRA EARIY ADAMS-Hardiest and earliest variety, but not a sweet corn. Brings a goor price when first offered on the market. I'kt., 15c; pint, 25c; 1 it., $40 \mathrm{c}$; postpaid. veck (14 ibs.), $\$ 1.00 ; 1$ bushel (56 lbs.), $\$ 3.75$ By parcel post, add postage.

BIACK MEXICAN--The grains when matured are blueblack, and when in edible state are cream color. Pht., 15c; pint, $25 \mathrm{c}$; quart, $45 \mathrm{c}$; postpaid. By freight or express $650 ; 1$ peck, $(10 \mathrm{lbs}), \$ 1.00 ; 1$ bushel, $(40 \mathrm{lbs}), \$ 3.75$. By parcel PEEP-O'DAY-A very dwarf but very early white variety. Pkt., 15c; pint, 25c; quart, $45 \mathrm{c}$. postpaid By express or freight, $1 / 2$ peck $65 \mathrm{c}, 1$ peck $(10 \mathrm{lbs}), \$ 1.00 ; 1$ bushe 50 lbs.), $\$ 3.75$. By parcel post, add postage.

MAMMOTH WHITE CORY-This is the favorite early variety with all market gardeners. Pkt., $15 \mathrm{c}$; pint, $25 \mathrm{c}$; quart, $45 \mathrm{c}$, postpaid. By freight or express, $1 / 2$ peck (61/ l lbs.) $65 \mathrm{c}$ 1 peck (12 1/2 ibs.), $\$ 1.00 ; 1$ businel $(40 \mathrm{lbs}$ ) $)$, $\$ 3.75$. By parcel post, add postage.

TUCKER'S BLUE RIBBON BARLY WHITE-Excellent corn for early market and table use, coming in a few days later than the Adams Early. Pkt., 10c; pint, 20c; quart, STOWELI'S EVERGREEN SUGAR-A standard variety of sugar corn, producing very large ears. Pkt., 15c: pint, 25c; quart, 45c; postpaid. By express or freight, $1 / 2$ peck (5 lbs.), 65c; 1 peck $(10 \mathrm{lbs}),. \$ 1.00 ; 1$ hushel (40 lbs.), $\$ 3.75$. By parcel post. add postage.

EARIY IARGE ADAMSS-Very early market variety; ent's good size. Pkt., 15c; pint 25c; quart, $40 \mathrm{c}$, postpaid. Br express or freight, $1 / 2$ peck ( 7 lbs.), $75 \mathrm{c} ; 1$ peck (14 lbs.) $\$ 1.00 \% 1$ lushel (reight, $1 / 2$ peck ( 7 lbs. $)$, $\$ 3.75$. By parcel post, add postage.

SHOE PEG OR COUNTRY GENTIEMAN (SUGAR)-A pOpular sweet corn, growing fair size ears, long grains. unevenly distributed. Pkt., 15c; pint, $25 \mathrm{c}$; quart, $45 \mathrm{c}$; postpaid. By express or freight, 1 peck (10 lbs.), $\$ 1.00 ; 1$ bushel (40 lbs.), $\$ 3.75$. By parcel post, add postage.

MAMMOTH SUGAR-A large medium late sugar corn, producing broad flat grains. Pkt., 20c; pint, $35 \mathrm{c}$; quart, $60 \mathrm{c}$, postpaid. By express or freight, $1 / 2$ peck ( 5 lbs.) $60 \mathrm{c}: 1$ peck $(10 \mathrm{lbs})$. $\$ 1.00:$ bushel (40 lbs.), $\$ 3.75$. By parcel post, add postage.

CROSBY'S FARIY-For inedium early use and general crop is one of the most desirable sorts. Plit., $15 \mathrm{c}$ pint, $25 \mathrm{c}$; quart, $45 \mathrm{c}$; postpaid. By express or freight, $1 / 2$ peck. (5 lbs.), $65 \mathrm{c} ; 1$ peck $(10$ lbs. $), \$ 1.00 ; 1$ (rel post. add postage.

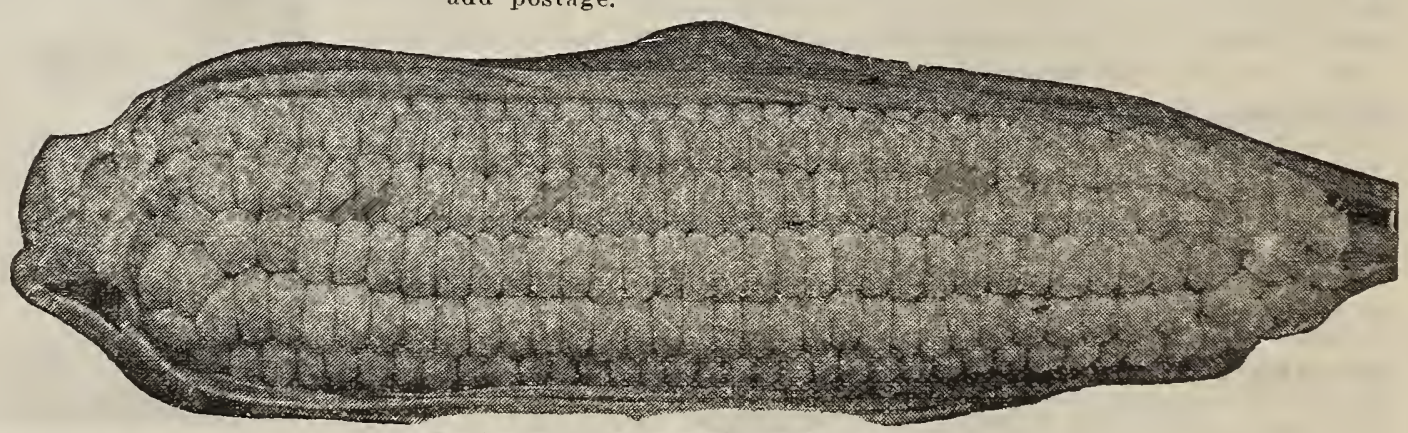

STOWEIL'S EVERGREEN

GOIDEN BANTAM-The most popular of all the early sweet corns. The demand for this variety is enormous and great difficulty is experienced in keeping the supply equal to the demand. It is rapidly taking the place of the white and older varieties on account of its better quality. "Grains are creamy yellow, very sweet and tender, and also fine flavor. Pkt., $15 \mathrm{c}$; pint, $25 \mathrm{c}$; quart, $45 \mathrm{c}$; postpaid. By express or freight, $1 /$ peck (5 lbs), $65 \mathrm{c} ; 1$, (10 lbs.), \$1.00: 1 bushel (40 libs.). \$3.75. By parcel post, add postage.

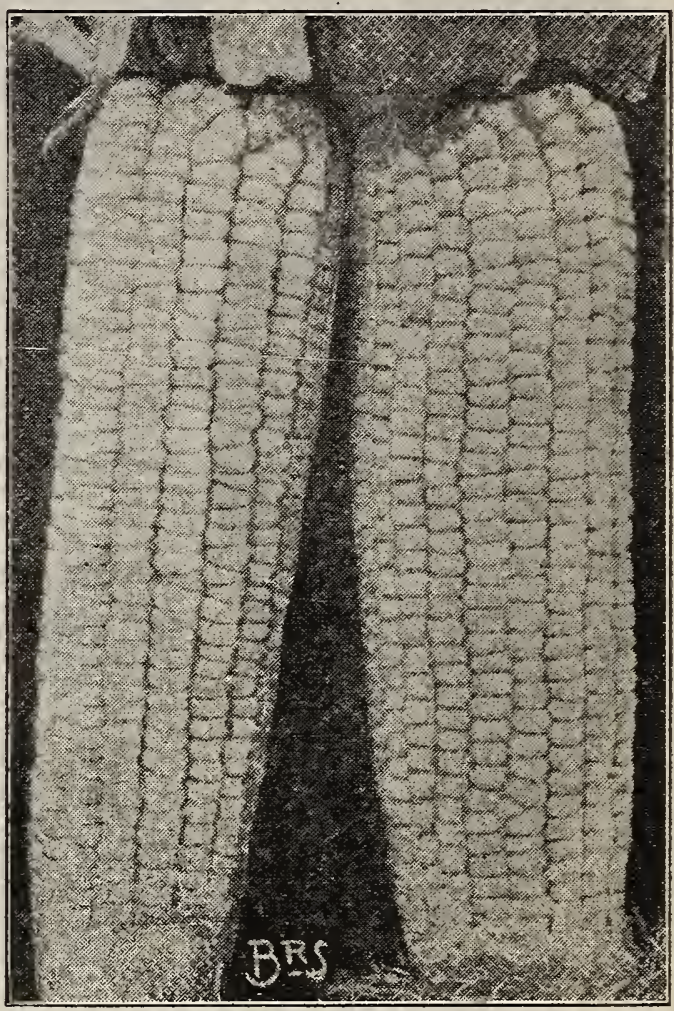

TUCKIR'S BTUT RIBBON 


\section{CUCUMBERS of QUALITY}

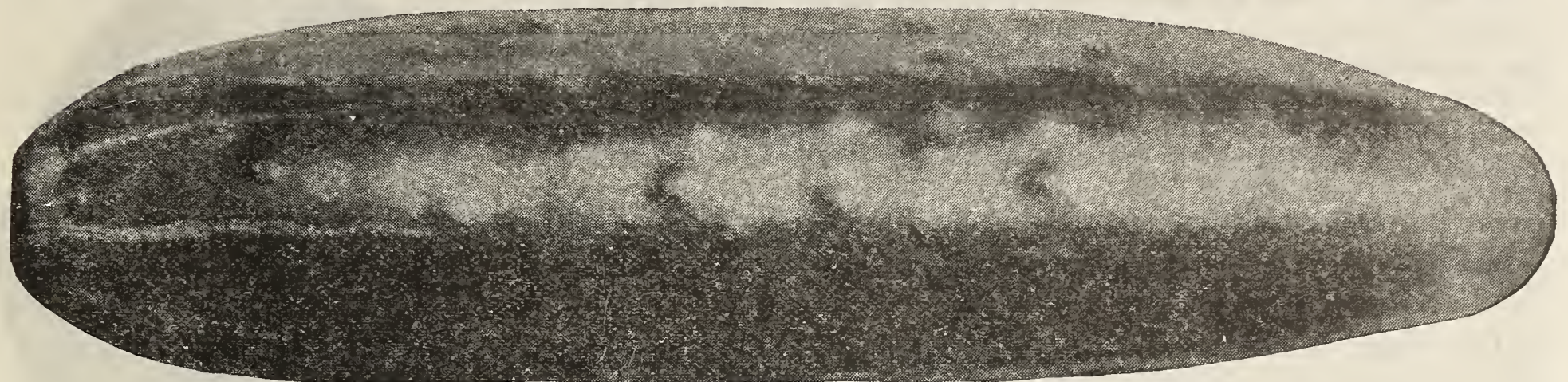

IMPROVED LONG GREFN CUCUMBER

Plant in hills four feet apart each way. One ounce of seed will plant fifty hills, or $1 \frac{1 / 2}{2}$ pounds to the acre. Cu cumbers succeed best in warm, rich, sandy soil, and should not be planted until all danger of frost is over. When al danger of insects has passed, thin out the plants, leaving three or four of the strongest plants in each hill.

DAVIS PEREFCT-A sure money maker for those engaged in growing cucumbers. Grows under glass as shape of Davis Perfect is ideal. It is seedless almost one-third the length from
the stems. It is a rich dark green and holds its. hosh is of excellent flavor: white, clear, erisp and tender. Plkt., 10e; oz., 15c; $1 / 4$ lb., 30c; lb., $\$ 1.00$, postpaid.

JAPANESE CIIMBING-This is a strong, vigorous grower; fine for pickling. Pkt, $5 \mathrm{c} ;$ oz $15 \mathrm{c} ; 1 /$ il, $30 \mathrm{c} ; \mathrm{lb}$. $\$ 1.00$, postpaid.

\section{FARIY GREFN CIUSTER-Fruits} are slim and highly desirable for pickles. Pkt., 5c; 07., 15e; I/4 1b., 30c; 1 1b., \$1.20, postpaid.

FVPRGRFFN PICKIING-Generally admitted to possess every qualification required in a perfect pickling cucumber. Exceptionally productive. It is a very strong grower; extra early and bears firm, crisp fruit, which is excellent for slicin. Pkt., 5e; oz., 15e; $1 / 1$ lb., $\$ 1.00$, postpaid.

GHFRIN OR BURR-A small oval-shaped pickle variety; used exclusively for pickles for which it is very desirable. Pkt., 5c, o\% $15 \mathrm{c}$. $1 /$ for which 1 lb., $\$ 1.25$, postpaid.

FARIY FRAME OR SHORT GREEN-Early productive, medium size, good shape Plit, $5 c^{\circ}$. $15 \mathrm{c} ; 1 / 4$ lb., 30c; 1 lb., $\$ 1.00$, postpaid.

KIONDIKE-A medium early, white spined eueumber of handsome, very dark green color and excellent for slicing. The vines are very hardy and produc tive. When matured are often about eight inches in KAIS $1 / 4$ Ib., 30c; 1 lb., $\$ 1.00$, postpaid.

IMPROVED EARIY WFITE SPINE-The vorite variety with nearly all gardeners and truck ers for early and main crop The fruits are ers for early and main crop smooth, of good shape, splendid deep greels color, to our stock of this is extra fine and well adapted, either for growing in greenhouses, frames or outside for early and late planting. Pkt., 5e;
$15 \mathrm{e} ; 1 / 1$ lb., 35e; 1 lb., \$1.00, postpaid. CUMBERIAND-A distinet variety of the White Spine type. The fruits are dark green, large, straight and symmetrical. Cumberland is as choice a slicing variety as it is for pickles. variety as it is for pickles. and of excellent yuality at all stages of growth. at all stages of growth. Pkt., 5e: 1 oz., 15e; $1 / 1$ postpaid.

IMPROVID I O NG GREFI - Long. cris and firm. A popular cu cumber for all purposes. highly prized for fam. ily use and pickling; about 12 inches long when fully grown, when fully grown, of dark green color. Pkt. $5 \mathrm{c}$; oz., $10 \mathrm{c} ; 1 / 1 \mathrm{lb}, 30 \mathrm{c}$

COOI AND CRISP-An early variety; very prolific. It has a dark green skin and is covered with knobs upon which the spines set this gives it a fine appearance for pickling. It is also a fine tabl variety; tender and crisp. Pkt., 5c; oz., 15c; $1 / 4$ lb., $35 \mathrm{c} ; 1 \mathrm{lb}$ $\$ 1.25$, postpaid.

JPRSFY PICKIING-Splendid pickling sort; makes long slende cylindrical pickle. Pkt., 5e; oz., 15c; 1/1 lb., $35 \mathrm{c} ; 1$ lb., $\$ 1.25$ postpaid.

NEW EVERBEARING-The merit of this variety is in the fact that the vines produce fruit continuously until killed by frosts. They exhibit at the same time Cucumbers in every stage of growth, but invariably of perfect form, even when quite very desirable for pickling. Pkt., $5 \mathrm{c} ; 0 \mathrm{z} ., 15 \mathrm{c}$

(b., 35 ; 1 lb., \$1.25, postpaid.

\section{BORECOLE}

Kale is more hardy than cabbage and ill stand through the entire winter in any ordinary season in the central and lower South. It is much improved in quality by being touched with frost. Of all the cabbage tribe this is the most finely flavored and it would be more generally grown were its good qualities more widely knwon. It is a favorable vegetable to furnish "greens" in the South during winter and spring, and for that use there is nothing better. Sow one ounce of seed for one hundred feet of row, three to four pounds per acre DWARF SCOTCH, OR SCOTCH GREENS-A dwarf variety rarely exceeding 18 inche in height, but spreading ou under good cultivation to feet in diameter: the leave are very beautifull curled, and of a brigl wreen. Pkt., $5 \mathrm{c} ; 1$ or $15 \mathrm{e} ; 1 / 1 / 4 \mathrm{~b} ., 30 \mathrm{c}$ GREFN CURIED GREFN CURLED About two feet high, Pkt., $5 \mathrm{c} ; 1$ oz., $15 \mathrm{c} ; 1 / 4$
lb., 20c; 1 lb., $\$ 1.00$; postpaid.

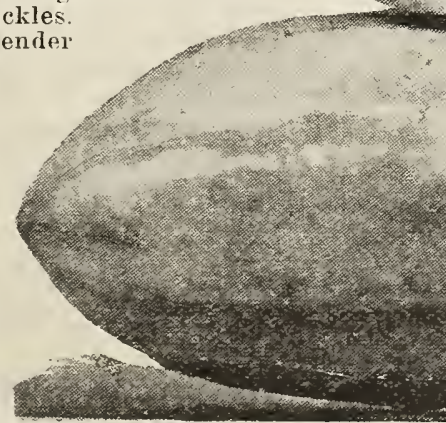


In February or March sow in hotbeds and keep warm. When two inches high, transplant to pots or to good rich soil. About the middle of May set out three feet apart each way, and protect. from bugs by dusting lightly with Slug Shot. We can supply customers with plants in case they have no hot beds to produce them. One plant produces two or three large fruits. One ounce of seed produces 1,500 plants. Four ounces to the acre. Ready for the table in one hundred ani twenty days from sowing.

IMPROVED SPINIIESS-This variety is almost entirely free from spines or thorns, and on this account more easily gathered. The $5 \mathrm{c} ; 0 \mathrm{z}, 25 \mathrm{c}: 1 / 4$ lb., $\$ 1.00 ; 1 \mathrm{lb} . . \$ 3.50$, post paid.

BIACK PFINI-An early variety with fruit nearly as large as the later sorts. Fruit nearly round, skin smooth, black, glossy; flesh white, fine grained and delicate. Pkt., $5 \mathrm{c} ; 0 \mathrm{z}, 35 \mathrm{c}$

$1 / 4$ lb., $\$ 1.25 ; 1$ lb., $\$ 4.00$, postpaid.

BIACK BFAUTY-Ten days to two weeks earlier than the New York Improved Purple. fruits a little bit longer in shape and slightly

darker. It is entirely free from spines around the corolla are dark rich purplish-black color; very attractive. Splendid for early crop or very late planting for market or family use. Pkt., 5c: oz., 35c; 1/4 lb., $\$ 1.25 ; 1$ lb., $\$ 4.00$, postpaid.

IMPROVED-IARGE PURPIF (SPINEIFSS)-This variety is a general favorite both for market and home garden. The plant is spineless, large and spreading, with light green foliage. It usually produces four to six large oval fruits of a splendid dark purple color. Pkt., 5c; oz., 35c; $1 / 4$ lb.. $\$ 1.00 ; 1$
lb., $\$ 3.50$, postpaid.

HORSE RADISH

Grow it in your own garden and grate fresh. Plant the sets small end down in rows 2 feet apart about 18 inches apart in the row. It does best in rich, loose soil set slant-

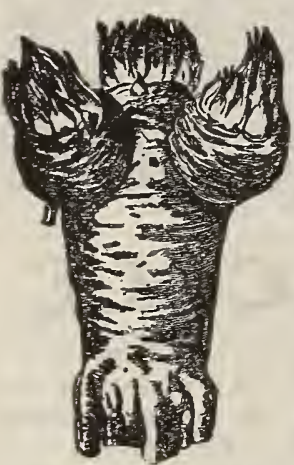
ing and covered about two or three inches.

Doz., 40c; 100 for $\$ 1.75$, postpaid. By ex ress, per $100, \$ 1.50 ; 1,000$ for $\$ 12.00$

\section{DANDELION}

Sow early in Spring, in very warn, rich soil, in drills 18 inches apart; thin to 5 inches apart and cultivate well; they will be fit for cutting the next spring. When grown for roots, sow in September and cultivate well during the fall and the following summer; the roots will be fit to dig in October. Pkt.

HORSFRADISH

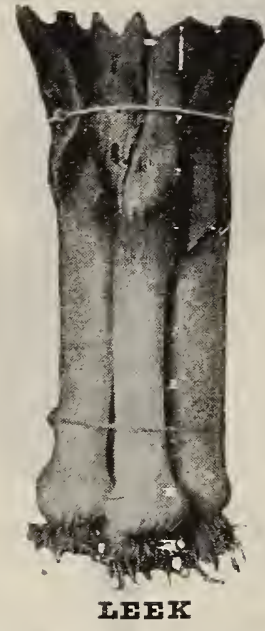

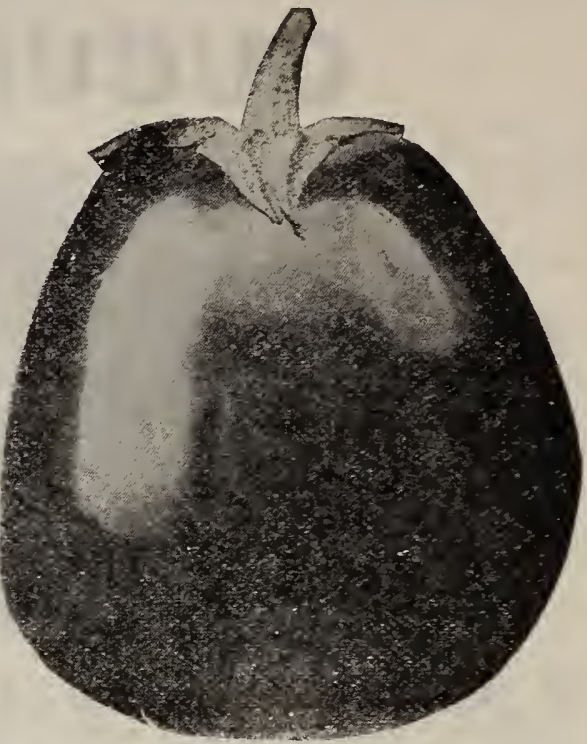

BLACK BEAUTY FGG PIANT LEEK

The Leek is generally considered superior to the onion for soup flavoring, etc. Sow early in the Spring in a light, rich, moist soil, in drills half an inch deep. When six or eight inches high trim off the tops and transplant to rows one foot apart and six inches apart in the row, setting them three to four inches deep and earthing up as ther grow, so that the necks will become well blanched. The seed may also be sown in September and the young plants transplanted in the Fall or early in the Spring to where they are to remain. One ounce will sow about one hundred feet of drill

IARGF FIAG-Very large and popular variety. Pelfectly hardr. Pkt.. je; oz., 15c; $1 / 2$ liety. $50 \mathrm{c} ; 1$ lb., $\$ 1.75$, postpaid.

\section{AROMATIC, MEDICAL AND POT HERBS}

Most of the varieties thrive on sandy soil and some are stronger and better flavored when they are grown on that which is very poor. In all cases the soil should be properly prepared and well cultivated, as the young plants are for the most part delicate and easily chocked out by weeds. Sow as early as the ground can be ready, in drills sixteen inches or eighteen inches apart, taking pains that the soil is fine and firmly pressed over the seeds. They may be planted as a second crop when the seeds are sown in beds in March and the plants set out in April. Most of then

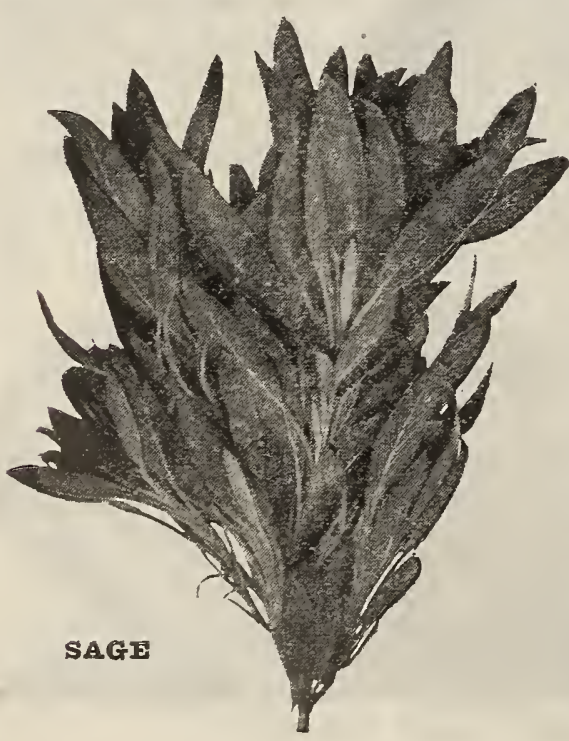
should be cut when in bloom, wilted in the sun and thoroughly dried in the shade.

SORREI (IARGE IFAVED FRENCH)The best garden variety, having large pale green leaves of fine ouality. Sow in drills early in the spring and thin the seedlings to six or eight inches apart in the row. One may commence cutting in about two months and the plants will continue in full bearing from three to four years. Pkt., 5c; 1 oz., 15c; 2 0z., 25c; $1 / 4$ lb., 50c $1 \mathrm{lb} ., \$ 1.75$, postpaid.

SAFrRON-A hardy annual. Pkt.. $5 \mathrm{c}$ : oz. $20 \mathrm{c}$; $1 / 4$ lb., 60c; 1 lb., $\$ 2.00$, postpaid.

ROSEMARY-A hardy perennial, Used for flavoring meats and soups. Pkt., 5c: 07.. 40c $1 / 4$ lb., $\$ 1.00 ; 1$ lb., $\$ 3.50$, postpaid.

DIII-Its seeds are used for seasoning. Its largest use is for dill pickles. Pkt., $5 \mathrm{c} ; 0 \mathrm{z} ., 10 \mathrm{c}$. $1 / 1$ lb., 30c; 1 lb., $\$ 1.00$, postpaid.

IAVENDER A hardy perennial, growing about two feet high. Pkt., 5c; oz., $25 \mathrm{c} ; 1 / 1 \mathrm{lb}$. $75 \mathrm{c} ; 1 \mathrm{lb}$., $\$ 2.50$, postpaid.

SAVORY, SUMMER-A hardy aromatic herb 12 or 15 inches high, extensively used for seasoning, especially in dressings and soups. Pkt.
THYME-An aromatic perennial herb eight or ten inches high, used principally for seasoning. Plit, 5c: 07, 40c; 1/ lb. \$1.25: 1 lb. $\$ 4.00$. postpaid.

SAGE-One of the most extensively used herbs for seasoning. Pkt., 5c; nz.. 20c; $1 / 41 \mathrm{l}$.. 60e lb., $\$ 2.00$, postpaid.

HOREHOUND-Perennial herl). Pkt. $5 \mathrm{c}$; oz. $25 \mathrm{c} ; 1 / 4 \mathrm{lb}, 75 \mathrm{c} ; 1 \mathrm{lb}$., $\$ 2.50$, postpaid.

ANISE-The leaves are sometimes used for Aninging and flavoring. Pkt. 5c;0z, 15c: 1/4 lb., 50c; 1 lb., $\$ 1.75$, postpaid.

CORIANDER-Used for flavoring. Pkt., כ 2. 20c: $1 / 1$ lb., 50c: 1 lb., $\$ 1.75$, postpaid.

CARAWAY-Used in confectionery, cakes, etc Pkt., 5c; oz., 10c; 1/4 lb., 35c: 1 lb.. \$1.00: postpaid.

BASII, SWEET-The seeds and stems have a strong flavor and are used in soups and sauces. etc. Pkt., 5c; ox.. 20c; $1 / 1$ lb.. 50c; 1 lb.. \$2.00. postpaid

MARJORAM, SWEET-Used for seasoning Pkt., 5c: 07., 20c: 1/, lb.. \$1.00; $1 \mathrm{lh}$.. \$3.00 Pkt., 5c: 


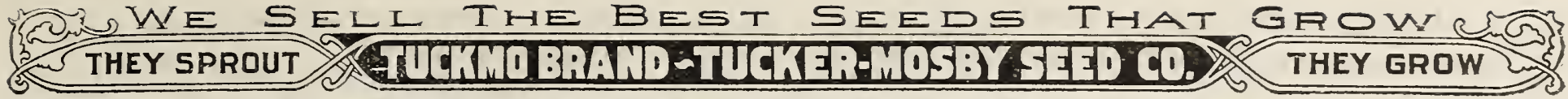 \\ TUCKER'S

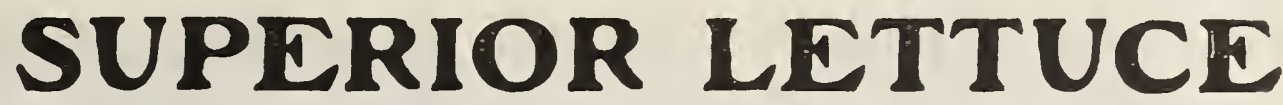

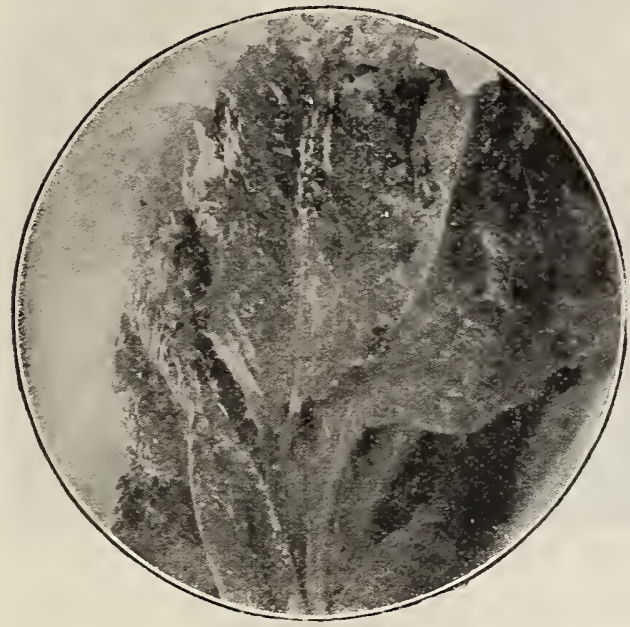

COS OR ROMAINF
One ounce of seed will produce about 2500 plants. Sow under glass in January or February for early use. Transplant as soon as the ground can be worked nicely. Sowing may be made in open ground from April to August, ten or twenty days apart for succession.

CAIIFORNIA CREAII BUTTER OR ROYAI SUMMER CABBAGE (Seed Brown)A very reliable heading sort, with glossy, deep green leaves, the outer ones slightly spotted or splashed with brown. The inner leaves forml a large, very solid head, rich light vellor

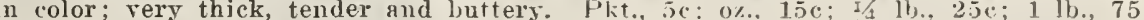

BLACK SEEDED SIMPSON-One of the best for sowing outdoors where an exceedingty tender leaf is desired and for those markets which demand a very large loose clustering sort The color is an attractive light yellowish-green. It is used also for growing under glas or in frames. The leaves are ruffled and blistered and even the large outer ones are ver tender. This curly and thin-leaved, bunching variety is uniformly attractive and remain. of excellent quality a very long time. Pkt., $5 \mathrm{c}$; oz., $15 \mathrm{c}$; 1/1 lb., $25 \mathrm{c} ; 1 \mathrm{lb} ., 75 \mathrm{c}$

BARIY PRIZE FrED (Seed White)-A large, clustering, non-heading lettuce, mos excellent for the home garden and undoubtedly the most easily grown variety in cultivation. It is too tender, however, to stand shipping or handling on the market. The leaves ar finely curled and crumpled, bright green tinged with brownish red and are very crisp, tender and sweet. Pkt., 5c; oz., 15c; 1/4 lb., 25c; 1 lb., T0c, postpaid.

DEACON-This lettuce does not grow as large as some sorts, but has few outside leaves: rrows very solid; delicious hutterv flavor. Center of head blanches to bright rellow shade vers crisp and tender, remaining so for long time, even in hot weather. One of the finest summer sorts. Pkt., 5c: oz., $15 \mathrm{c} ; 1 / 4 \mathrm{lb}, 25 \mathrm{c}$ : 1 lb., $70 \mathrm{c}$, postpaid.

BOSTON MARKEF-An old popular variety for forcing heads HUBBARD MARKST-Matures very quickly; large size, handare small and compact. Pkt.. 5e: 07.. 15e; 1/4 lb.. 30e; $11 \mathrm{lb}, 85 \mathrm{c}$, postpaid.

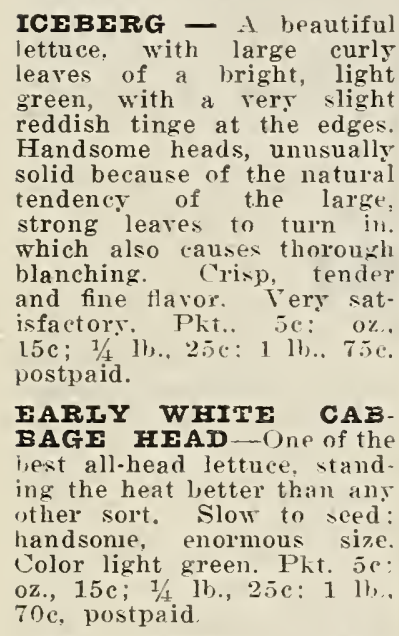

COS LETTUCE (RO. MAINE) - Cos Lettuce is narrow, spoon-shaped leare folding into loose, sugar-loaf shayed heads which blanch better by having the outer leaves drawn about them and tied. Sow seed early in the spring, in rich. well prepared soil. in row eighteen inches apart, covering one-half inch deep. When plant have two or three leaves thin to three or four inches apart. A. the plants begin to crowd, thin and use as required. If lar'se apart. Pkt.. 5c; 0z.. 15c; I/4 lb., 35c; $1 \mathrm{lb} ., \$ 1.00$, postpaid.

EARIY TENNIS BAII (Seed Black)-One of the best heading lettuces, especially desirable for early planting outdoors and also suitable for forcing. The plants are large, with thick, bright green leaves. They form very solid heads, the inner leaves blanching to a rich creamy white, and are crisp, tender

ST. LOUIS MARKET-An excellent rariety for early spring and sunmer use, or for winter forcing. Heads white and rely firm an compact. Pkt., 5c; oz., 15c; 1/1 lb., 30c; 1 lb.. 85c, postpaid.

MAY KING (Seed White)-This is a handsome, extremely early. compact, cabbage or heading variety for the home garden ani market, forming very firm heads of medium size and excellen ruality. The color is light yellowish green, tinged with reddish brown sellow, very tender and buttery. The plant is very com pact for so large a head. The variety is exceptionally early ontdoors, attaining a size suitable for use before other sorts and is also very satisfactory for forcing. Pkt., 5c; oz., $15 \mathrm{c} ; 1 / 1 \mathrm{lb} ., 35 \mathrm{c}$ $1 \mathrm{lb} ., \$ 1.00$, postpaid

EARIY CURLED SEIESIA-The most popular of the "curled or loose heading sorts, grows erect and is one of the best for early use, as it can be used when very young and grows rapidly: color light green, leaves much curled, of the very best quality white seed. Pkt., $5 \mathrm{c}$; 0z., $15 \mathrm{c}$; $1 / \mathrm{l}$ lb., $30 \mathrm{c} ; 1 \mathrm{lb}$., $85 \mathrm{c}$, postpaid. ll.. $85 \bar{c}$ c, postpaid.

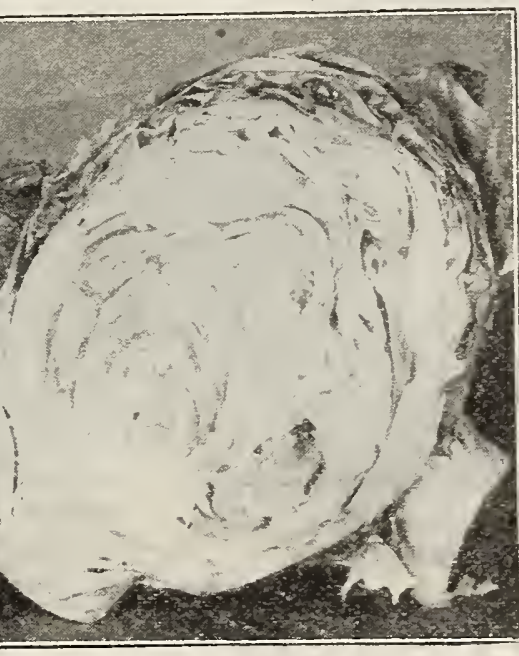
ariety for forcing in cold

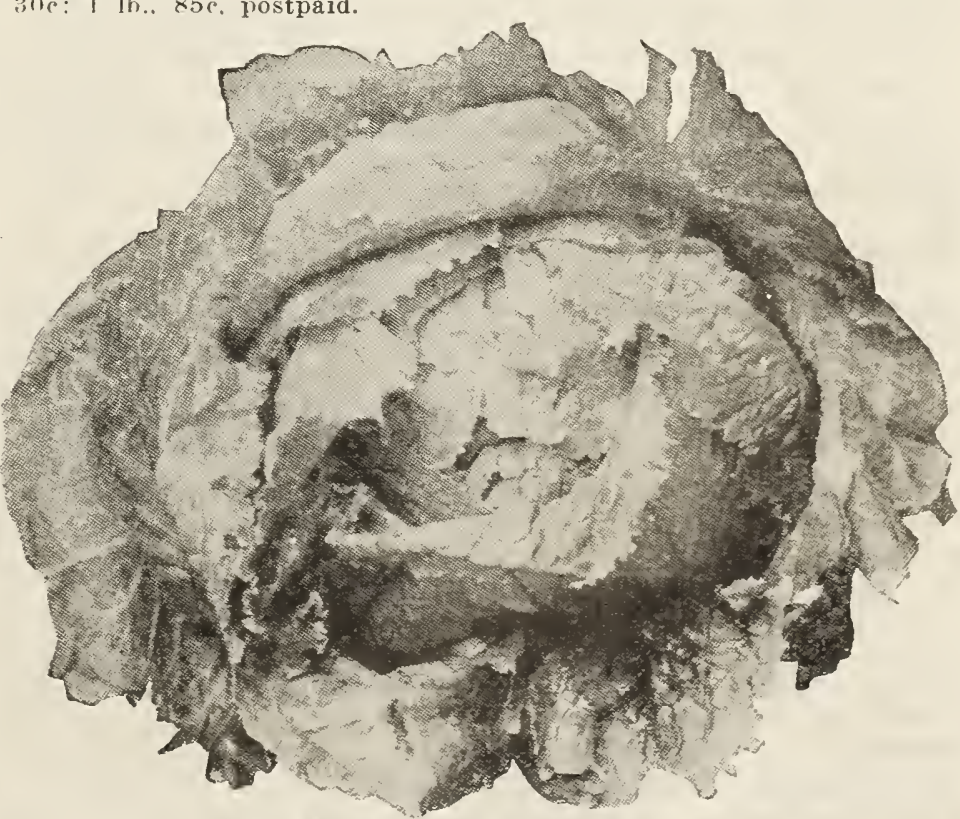

TUCKER'S BIG BOSTON

TUCKER'S MAMMOTH hard heading variets, large, does especially well in this climate. It is equally The outer leaves are very road, smoothly rounded, or grow up tightly folded and he inner leaves are blanch ed to a beautiful white and
curled like a Savoy Cabbage. The flavor is rick and buttery, the leaves bedelicate. Packet, 5e; $15 \mathrm{c} ; \quad 1 / 1.1 \mathrm{~b} ., 40 \mathrm{c}$

TUCKER'S BIG BOS identical in color, shape and fameral appearauce with the tuce, but it is double the size. It is about a week later in maturing, but it

\section{.}




\section{TUCKER'S SUPERIOR LETTUCE -Continued}

GRAND IARIDS (Seed Black)-As a lettuce for greenhouse forcing this variety undoubtedly stands at the head of the list, being of quick growth, hardy, little liable to rot and remaining in condition several days after being rot and rems cluster of large, thin, bright green leaves, savoyed, finely crimped at edges. The leaves do not wilt quickly after cutting so that the variety will stand shipping long distances better than most sorts. It is a very attractive rariety and is desirable for garnishing. Pkt., 5c; oz., 15e; 1/4 lb., 3.; c; 1 lb., $\$ 1.00$, postpaid.

SIMPSON'S EARIY CUEIID (Seed White)-A very extensively used early loose leaved, or clustering variety. The leaves are light green in color, slightls frilled and much blistered, crisp, sweet and tender." This sort is éspecially adapted for sorring thickly and cutting when especially adapted for sowing thickly and cutting when 1 1b., $85 \mathrm{c}$.

EANSOF (Seed White)-One of the most desirable later summer lettuces. The plant is compact and forms a large, cabbage-like head which remains in condition longer than most heading sorts. The outer leaves are bright crumpled and frilled at edge with distinctive

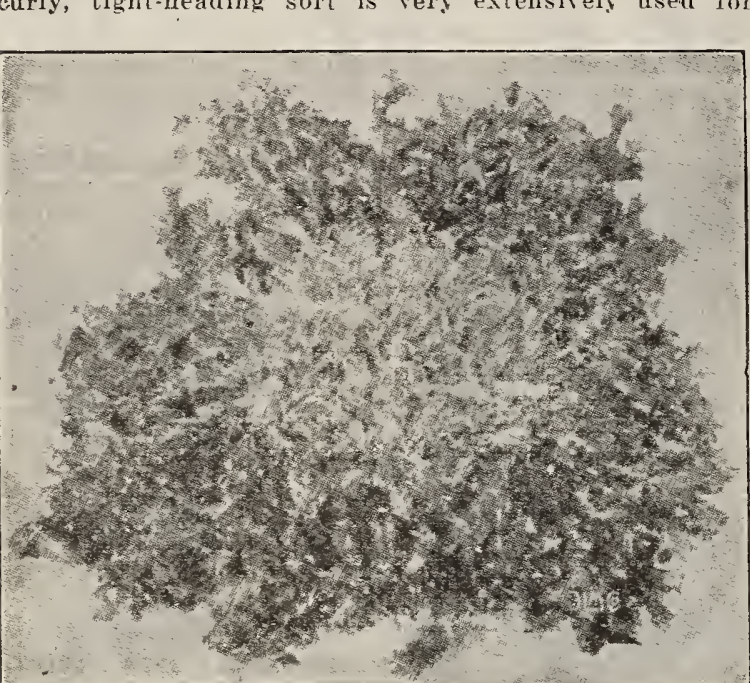

GFEבA CUREED FNDIVG

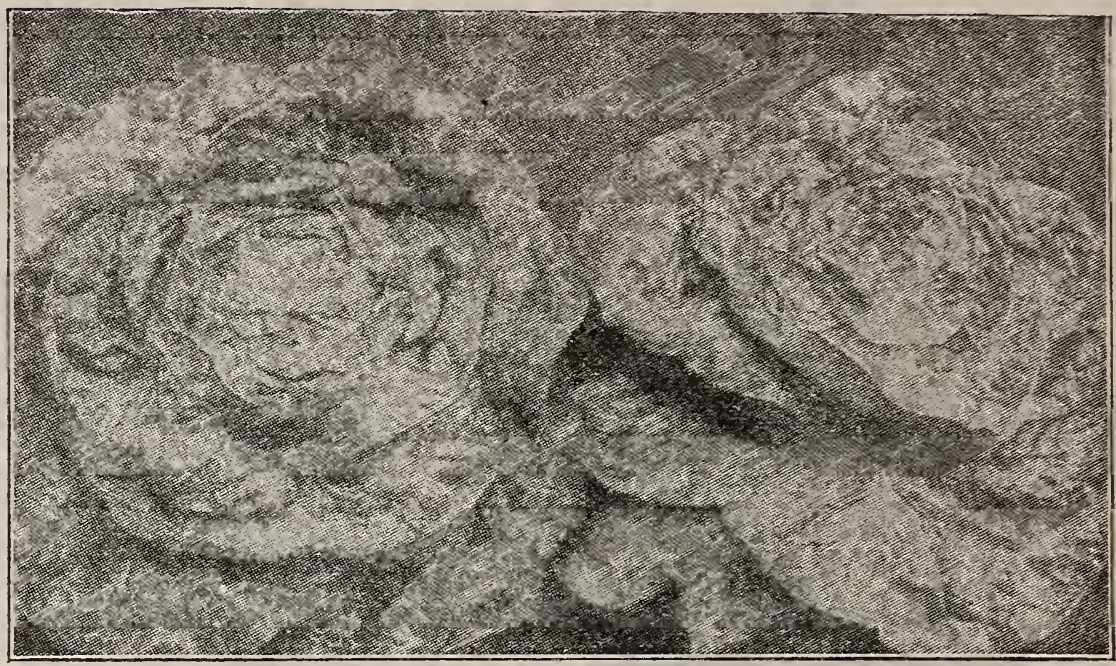

XANSON TITTUCE

midrib. The inner leaves are white, very crisp and sweet. This thin-leaved,

\section{ENDIVE}

A very delightful and refreshing vegetable; used mostly for salar and a substitute for lettuce, which it resembles. Endive may be grown at any season of the year, but generally in the late fall. Sow in August in drills eighteen inches apart, and thin out to one foot apart. When nearly grown, tie up the outer leaves to blanch the heart. In dry seasons give plenty of water.

GRFEN CURIED-This is one of the hardiest and best varieties for general se. Pkt., 5c; oz., 15c; $1 / 4$ lb., 30e; 1 lb., $\$ 1.00$, postpaid.

\section{KOHL RABI}

(Turnip Rooted Cabbage)

For early use sow in hot beds or in the open ground in March or April, in rows eighteen inches apart, thin out or transplant like cabbage. Can also be sown in June or July for fall use. One ounce of seed will sow 200 feet of drill.

Plant some of this delicious vegetable in your garden.

EARIY WHITE VIENAA-Greenish white outside, with clear white flesh within. Smooth short leaves, fine qualit.. Pkt., 5c; oz., 20c; 1/t lb., $40 \mathrm{c}$ 1 lb., \$1.50, postpaid.

\section{MUSTARD}

This is grown to quite a large extent in the Southern States. It is used the same as Spinach or boiled with meat as greens. The white or yellow-seeded variety is cultivated chiefly for medicinal purposes or flaroring.

Sow during February, March or April, or in the fall during September or October, either broadcast or in rows six inches apart. Cut when three inches high. Sow one ounce to eighty feet of drill, or broadcast at the rate of five or six pounds per acre.

SOUTHFRN GIANT CURLFD-Leaves large, very popular variety. Plit., $5 c ; 1 / 1 \mathrm{lb}$ $20 \mathrm{c} ; 1 \mathrm{lb} ., 60 \mathrm{c}$, postpaid.

CHINISE-A very fine, large, thick-leaved rariety; hardy and of excelent flavor. Pkt., $5 \mathrm{c} ; 1 / 41 \mathrm{~b} ., 25 \mathrm{c} ; 1 \mathrm{lb}$., $75 \mathrm{c}$, postpaid.

BLACK OR BROWN-Pkt., 5c; $1 / 1 / 1 \mathrm{~b} ., 20 \mathrm{c} ; 1 \mathrm{lb} ., 60 \mathrm{c}$, postpaid. WHITE FNGIISE OR LONDON-Leaves are white and when young are

\section{MUSHROOM SPAWN}

Mushrooms can be grown in cellars, sheds, green houses and hotbeds. Sometimes they are planted in open air. Use fermented horse manure at the temperature of 70 degrees, mix equal weight of fresh sod loam. The beds may be marle of the size required and should be eight inches deep, packed well and evenly. In these beds plant the broken spawn about 1 to $11 / 2$ inches in diameter, 6 inches apart, cover with 2 inches of light soil. Water should be used sparingly and should be lukewarm. Mushrooms will appear in about six weeks.

BEST ENGISIS-1I/4 13), bricks, 50c, postpaid, not prepaid, $40 \mathrm{c}$ each

\section{WHEN TO ORDER YOUR SEEDS}

Now is the time to order your seeds, while you have the subject fresh on your mind. Don't put it off until tomorrow. By sending in an order now you will have the seeds when wanted. 


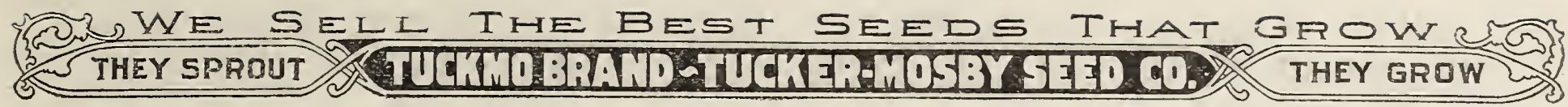

\section{CANTALOUPE AND MUSKMELON}

One ounce of seed will plant fifty hills, two pounds to the acre. Sow in a warm, rich, loany soil; plant in hills five $0 i^{\circ}$ six feet apart each way; plant 10 or 12 seeds to the hill. When danger of insects is over, thin out to 4 plants to the hill. They should not be planted until settled warm weather begins. In this section, about the middle of April. This method insures a good stand of head plants.

\section{GREEN FLESHED VARIETIES}

HONEY DEW IMEION-The delicious honey-like flavor of this new melon created a sensation wherever used last year. The fruit is of good size, weighing 6 to 8 pounds; light cream colored, smooth skin with thick, rich and sweet flesh of light green color. The rind is thin but tough and so close that the rich flesh is practically sealed up where it keeps in finest condition for several months after it is ripe $15 \mathrm{c} ; 1 / 4$ lb., 35c; 1 lb., $\$ 1.25$, postpaid.

TUCKER'S ROCKY FORD-This famous melon is known everywhere, and has been the standard shipping variets for sever'al jears. The melons are the true netted gem type, medium size, oval, very sweet and fine flavored; very prolific, and continues bearing enormous quantities of fruit during the entire season. Onr seed are grown for us at Rocky Fordect melons. Pkt., 5c; o\%, 15c; 1 , 1b. $30 \mathrm{c} ; 1 \mathrm{lb} ., \$ 1.00$, postpaid.

FARIY HACKENSACK-Ten days earlier than the large Hackensack, roughly netted; flattish shape, good quality. Pkt., $15 \mathrm{c} ; 1 / 1 \mathrm{tb}$., $25 \mathrm{c} ; 1 \mathrm{lb}$., $85 \mathrm{c}$, postpaid.

MONTREAI MARKRT-One of the larg. est and finest flavored and spiciest of cantaloupes. Requires more careful cultivation than most varieties, but its superior quality and flaror make it well worth the extra troulle. The melons frequently weight eight lb., 30c; 1 lb., 85 c postpaid.

GRIBI CITRON-An early well-known sort; sweet, juicy and delicious. Pht., $5 \mathrm{c}$ oz., $15 \mathrm{c}$; $1 / 4$ lb., 35c; 1 lb., $\$ 1.25$. postpaid. JENNY IIND-Is of verT fine quality small size, heavily ribbed and netted: ols long; dark green flesh; extra early. An idea mones maker. Pkt., 5c: oz, $15 \mathrm{c}$; $1 / 4 \mathrm{lb}$. $35 \mathrm{c} ; 1 \mathrm{lb}$, \$1.00, postpaid.

CHICAGO MARKrT-A large, round melon. mucl esteemed in the Chicago marJFNNY
let. Green flesh, which is thick, fine rained and rery sweet. Pkt.,
$5 \mathrm{c} ;$ oz., 15c: $1 / 4$ lb., $35 \mathrm{c} ; 1 \mathrm{lb}$.. $\$ 1.00$. postpaid

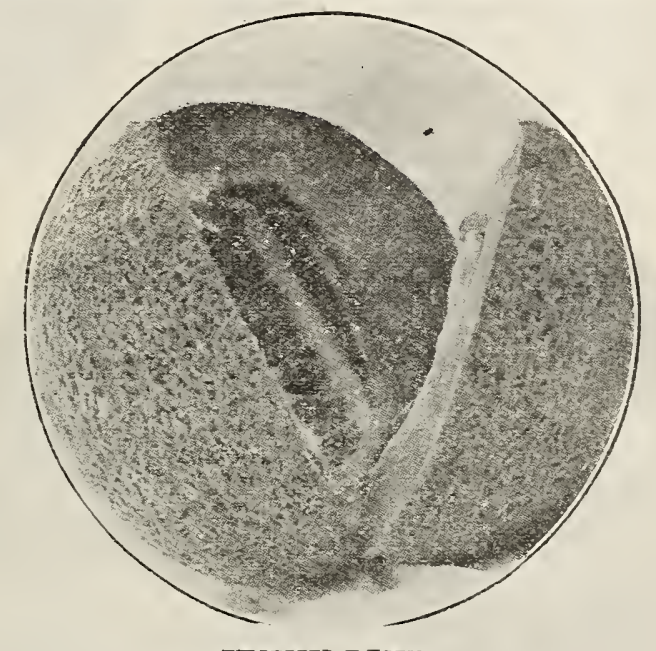

JTNNY IIND

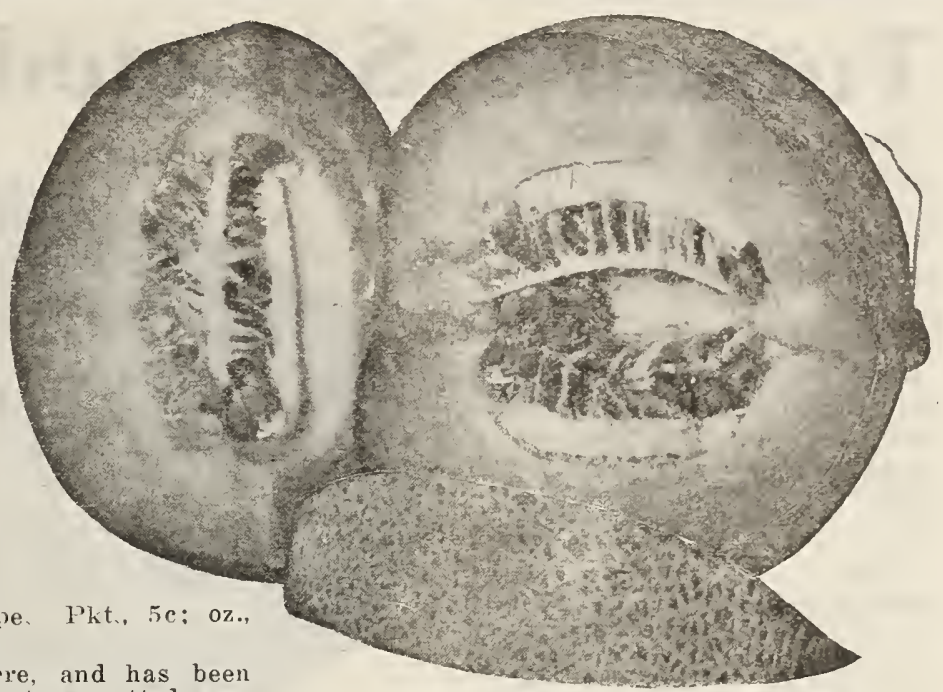

NETTED GFM

CHAMPION MARKET-The fruits are large, round or slightly oval, sliglitly ribbed and covered with dense netting. The flesh i green, very thick and sweet. The variety is a reliable, medium early market sort, an improvement on Montreal in earliness and productireness and will suit those who like a large, sweet, green fleshed

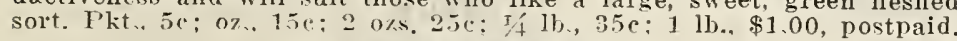

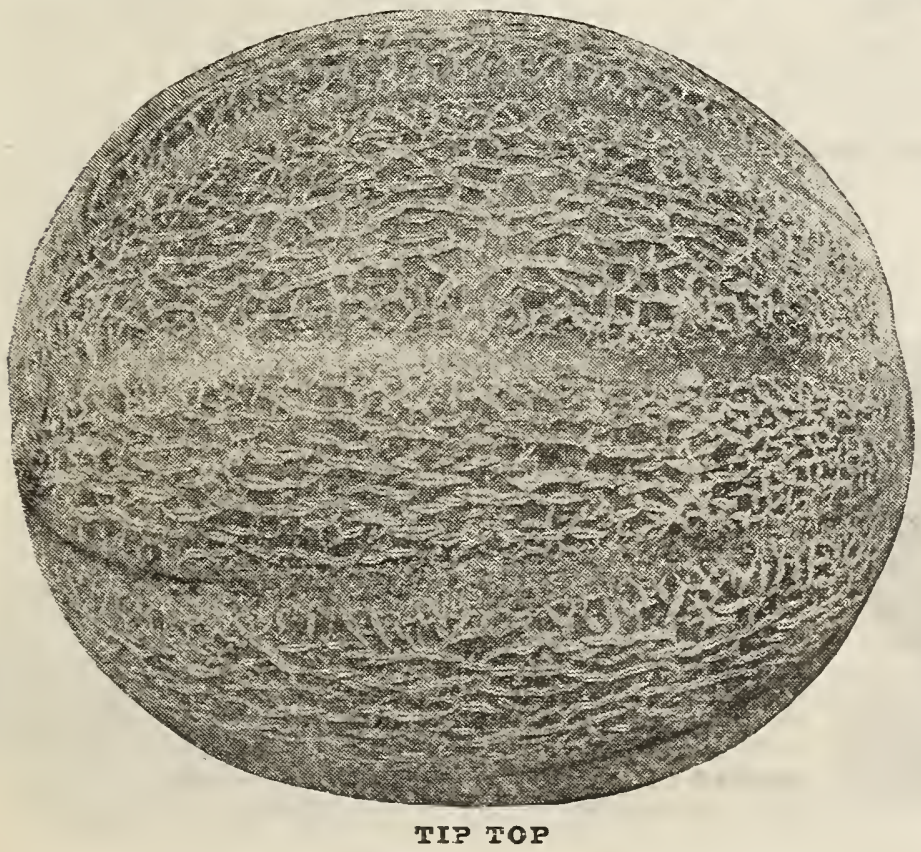

IFTrF GEI-This has become one of the most popular of small or crate melons. The vines are vigorous and productive, The fruits are oval, slightly ribbed, densely covered with fine highly flavored. The fruit is vers uniform in shape and quality and of fine size. Pkt. postpaid.

ORANGE FLESHED

\section{VARIETIES}

PETOSKEY OR PAUL ROSE-OWIII to its superiority as a shipper, there is a
very great demand for this melon from narket growers. It is an ideal melon, form oval, about five inches in diameter, shape Gem; of a light green or faint golden lme when ripe; flesh very firm; a fine rich orange red like the Osage, but much sweete to the rind and the seed cavity is exceelingingly small. Packet,

HOODOO-The vine is quite vigorous, re sisting blight better than most other sorts and is very productive. The fruits vary slightly in shape, areraging nearly round, quite like Netted Gem. Pkt., 5c; oz., 15c; 1/t lb, $30 \mathrm{c} ; 1 \mathrm{lb}$., $\$ 1.00$, postpaid

SOUTHERN PRIDE-One of the best sorts for home and marke use. The melons are of the netted type. Oral, medinm size, rery
sweet and fine flavored. Pkt.. 5c; oz. 15c; $1 /$ lb., 30c; 1 lb., $\$ 1.00$, sweet and
nostpaid.

BURRIII GEM-A superior new orange-flesh shipping melon. Of splendid flavor, sweet and aromatic; oblong in shape, smoothly rounded ends closely netted and slightly ribbed; dark green skin. The rind is thin, but very tough; flesh exceptionally deep rich salmonPkt., 5c; oz., 15c; 1/1 lb., 30c; 1 lb., $\$ 1.00$, postpaid.

BANANA CANTALOUPE-We again have a suppli of this splendid rariet $y$ with its banana-like flavor. Melons grow twenty-four to thirty inches long, stand summer sun as 170 other cantaloupes wil and continue to bear until late in

GEM EMERALD-Medium size. oval, smooth. green rind, thick salmon flesh. The rind is thin. ribberl, slightly netted. One of the best for home use. Ripens early. Pkt., 5c; oz., 15c; $1 / 4$ lb., $30 \mathrm{c}$; 1 lb., $\$ 1.00$, postpaid.

TIP TOP-Superior stock, large. attractive, bright salmon flesh, nearly round; ribbed, netted: rers mroductive. Pkt., 5c; oz., $15 \mathrm{c}$ $1 / 4$ lb., $30 \mathrm{c}$; 1 lb., $\$ 1.00$, postpaid.

OSAGE OR MIIIER'S CREAM-A favorite salmon-fleshed ra riety. Large oval, slightly ribbed and netted; skin is very dark green; flesh is very thick and sweet flavored, most delicious to the rind. The whole crop is very even and fruit extra heavy, owing to this thickness of the flesh. A great favorite for both market purnoses and the home garden especially. Pkt. $5 \mathrm{c} ; 0 \%, 15 \mathrm{c} ; 1 / 1 \mathrm{~h}$., 30 1 lb. $\$ 1.00$. postpaid 


\section{Tucker's Selected Watermelon Seed}

One ounce of seea will plant thirty hills, three pounds to the acre. About the middle of April is the proper time to plant melons in this section. Cultivate like cantaloupes, giving more room; eight feet apart each way, from six to ten seeds, one inch deep, and thin out to three of the best plants. A light, sandy soil, with plenty of sun is the best for watermelons.

PEIRIESS-Fruit medium sizel and oblong in shape, dark greell
rind, flesh bright scarlet, solid rind, flesh bright scarlet, solid
crisp, tender, and of the highest crisp, tender, and of the highest
lavor. Vines moderately vigorous, hardy and productive. Pkt., $5 \mathrm{c} ;$ oz., $10 \mathrm{c} ; \mathrm{C}^{1 / 4}$

JORDAN'S GRAY MONARCH-Light green, oblong, large size and good quality. In high favor for home use, shipping

Pkt., 5c; Oz., 10c; $1 /$ I PHINNEY's EARLY oblong, rind a distinct mottled color. Pkt. $5 \mathrm{c}$; oz., $10 \mathrm{c}$; $1 / 1 \mathrm{lb} ., 25 \mathrm{c} ; 1 \mathrm{lb}$., $75 \mathrm{c}$, postpaid.

HARRIS' EARIIEST-Extra early Fruits large, slightly oval, with irreg. ular, mottled, broad stripes of light and dark green; flesh bright red, aweet and tender. Seed black. Pkt., $5 \mathrm{c} ;$ oz., $10 \mathrm{c} ; 2$ oz., 15c
1 lb., $\$ 1.00$, postpaid.

CITRON-Medium, round; used for preserves; seed red. Pkt., 5c; 0\%, $10 \mathrm{c} ; 1 / 4 \mathrm{lb} ., 35 \mathrm{c} ; 1 \mathrm{lb}$., $\$ 1.10$, postpaid. CUBAN QUEEN-A large variety, weighing 80 pounds and upwards striped light and dark green; an en mous cropper. Pkt.. 5c; 07. SWEETHEART-The vines are vigtheir fruit evenly. Pkt., $5 \mathrm{c}: 0 \mathrm{n}, 1_{\mathrm{c}}$ 2 oze, 15c; $1 / 1$ lb., $25 \mathrm{c} ; 1 \mathrm{lb}$, $85 \mathrm{c}$, postpaid.

TRIUMPH - A Southern variety, has a thin and firm rind which make it an excellent shipper. Flesh bright red and of good quality; seed black. Pkt., 5c; oz.,

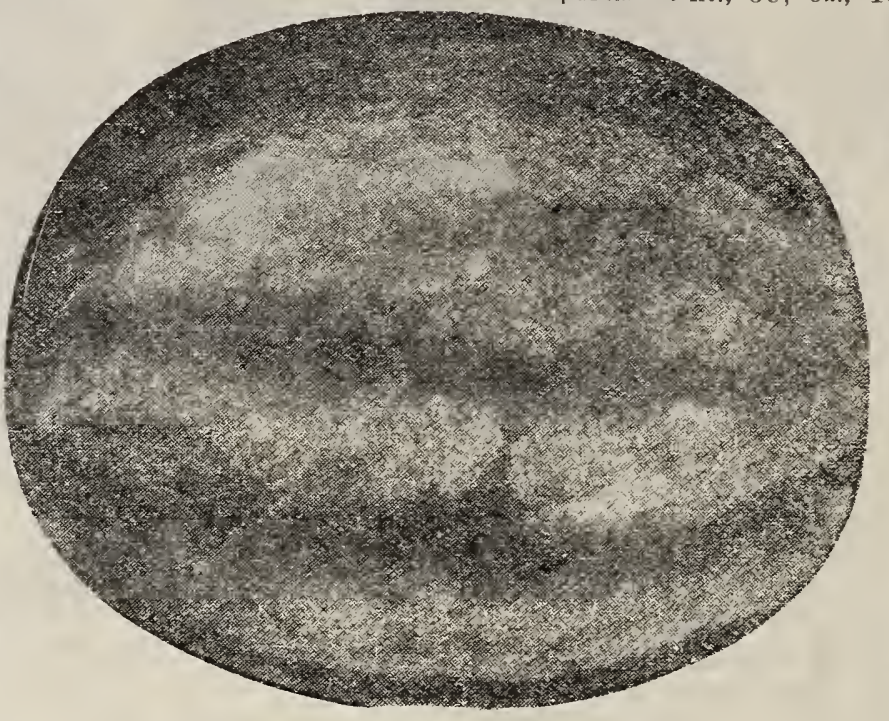

KOLB'S GSM

EXCEI-A large oblong melon of a dark green color with fain stripes. The tough rind permits rough handling in transit, making it a good shipper. It grows usually bigger and longer than the Watson. The flesh is of fine quality, and intense red to rind. Matures in about 90 days. This melon has black seeds, also white with a black border. The type is not well established, and some crops tend to proluce sports. Pkt., 5c;07., 10c; 1/.1 lb., $25 \mathrm{c} ; 1 \mathrm{lb}, 85 \mathrm{c}$, postpaid.

IRISH GREY-It's sweet; the Hesh is red, crisp and free from stringiness and in color of rind a mottled greenish grey, entirely distinct. Rind is thin but very tough. Shipments made last summer went through perfectly. Vines very vigorous, healthy and hid up and produce fine melons late into summer when other sort

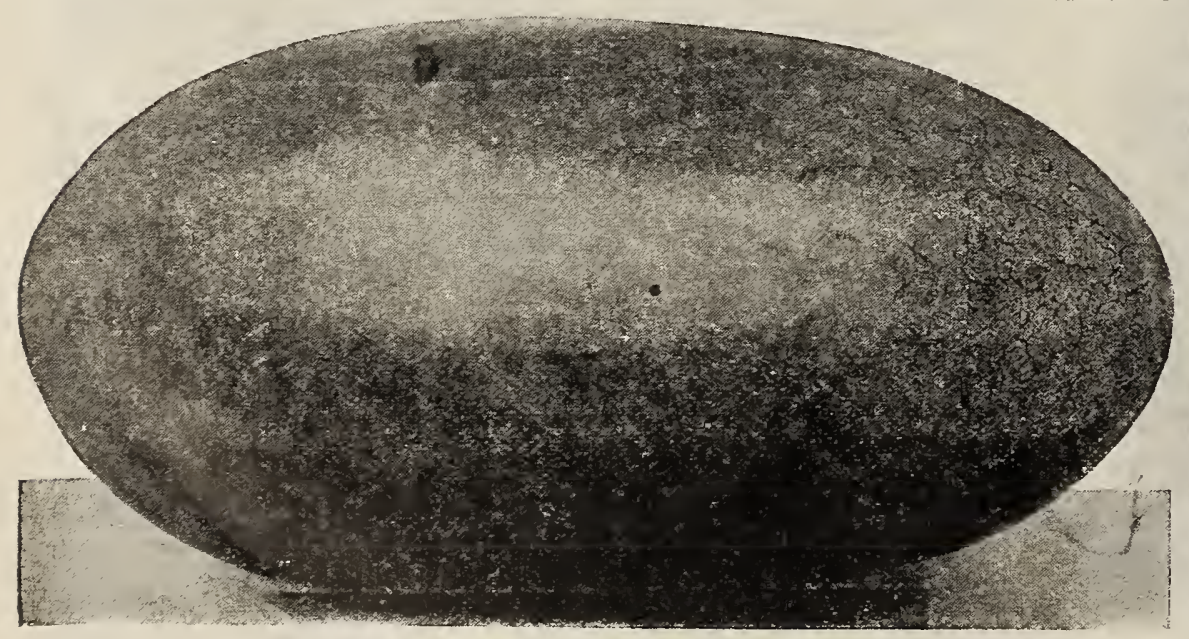

TUCRER'S IMPROVED TOM WATSON
GEORGIA RATTIESNAKE-The old standard variety, large oblong, triped; flesh of fine quality. Pkt., $5 \mathrm{c}$; oz., $10 \mathrm{c} ; 1 / 1 \mathrm{lb}, 25 \mathrm{c} ; 1 \mathrm{lb}$., $85 \mathrm{c}$.

ALABAMA SWEET-The color is rather deep green with dark, irregular striping. Rind thin, but vers tough; flesh bright red, fine grained and sweet. Pkt.. 5c; oz, 10c: $1 / 1 \mathrm{lb}$ $25 \mathrm{c} ; 1 \mathrm{lb}$, $85 \mathrm{c}$, postpaid.

BLACK DIAMOND-Immense in vize, the common weight of this melon is from sixty to eighty pounds. The rind hard and firm, which makes it superior for long distance shipping. In shape it is nearly round. Color
solid dark green. Flesh deep red and fine quality Pkt.. 5e; oz., $10 \mathrm{c}$; $1 /$ lb., $25 \mathrm{c} ; 1$ ib., $85 \mathrm{c}$, postpaid.

HAIBERT'S FONFY-Oblong in shape, rind dark green; flesh crimson. $85 \mathrm{c}$, postpaid.

TUCXER'S IMPROVIU TOM WATSON-Is quite distinct from al other varieties. It originated in

a really first-class watermelon should be. The rind is thin, but very tough, and the flesh is a bright, attractive red culor, of a sweet, dedell and market. Pkt., 5c; $0 z ., 10 \mathrm{c} ; 1 / 41 \mathrm{~b} ., 35 \mathrm{c} ; 1 \mathrm{lb}$., $\$ 1.00$, postpaid. TUCKER'S KECKIEY'S SWrET-This is one of the best flaTUCKER'S KECKIFY'S SWFET-This is one of the best flaly desirable. The rind is very dark green, thin, flesh deep ket. Pkt., 5c; oz., 10c; $1 / 1 \mathrm{lb}$., $30 \mathrm{c} ; 1 \mathrm{lb}$., $\$ 1.00$, postpaid. KOIB'S GFM-Famous shipping sort, oval, dark mottled green, very tough rind, solid flesh, large and attractive. Pkt., $5 \mathrm{c}$; oz., $10 \mathrm{c}$; $1 / 4$ lb., $20 \mathrm{c}$; 1 lb., $65 \mathrm{c}$, postpaid.

TUCKER'S BRADFORD-Fine flavored, large shipping melon, oblong in shape, rather square ends. The skin is very dark-green with darker stripes; flesh very tender and solid. Pkt., 5c; 0z., 10c; $1 / 4$ lb., 30c; 1 lb., $\$ 1.00$, postpaid. COIE'S EARIY-Very hardy, sure cropper, medium size nearly round. Rind green striped, flesh dark red, very deli. cate and sweet. Pkt. 5c;0z. 10c; $1 / 1 / 1 \mathrm{lb} .25 \mathrm{c} ; 1 \mathrm{lb} .75 \mathrm{c}$ PRIDE OF GEORGIA-A popular melon and a farorite market kind. Oblong, large, striped, bright scarlet; vers sweet flesh, nearly white seeds. Pkt., $5 \mathrm{c} ; 1$ oz., $10 \mathrm{c}$; $1 / 2$ lb., $25 \mathrm{c} ; 1$ lb., $85 \mathrm{c}$, postpaid.

FIORIDA FAVORITE-A very large melon, long not tled dark green, with stripes of lighter shade, rind thin but firm flesh. Very bright, deep red, sweet, tender and excellent. Pkt., $5 \mathrm{c}$; oz., 10c; 1/1 1b., 25c; $1 \mathrm{lb}, 85 \mathrm{c}$. dark mottled green in two shades forming indistinct stripes.

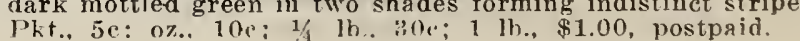




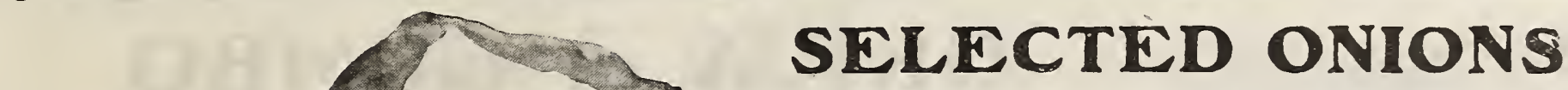

Onion seed should be sown as soon as possible in the spring, even if the weather is cold, just so the soil works up well. This gives the onion a good start and ahead of weeds and before dry weather set. in. After thoroughly pulverizing the soil, sow four or five pounds to the acre in drills one foot apart and about one-quarter of an inci deep. When four inches high, thin out to stands three to four inche apart in the rows, keeping them well hoed and free from weeds. SOUTHPORT WHITE GIOBE-An Onion that always fetches tip-top price owing to its handsome appearance. It is silvery white in color, globe shape in
form, flesh pure white, and of most delicious flavor and a grand keeper. Pht., $5 \mathrm{c}$ form, flesh pure white, and of most
$0 z_{\text {z., }} 20 \mathrm{c} ; \mathrm{I} / \mathrm{l}$ lb., $65 \mathrm{c} ; 1 \mathrm{lb}$., $\$ 2.25$.

SOUTHPORT RED GIOBE-A very handsome Onion, of immense size, aver aging 9 to 10 inches in circumference; solid, heavy and of perfect globe shape the skin is a rich, purplish red; flesh pure white, very crisp and mild. Fkt., כe oz.. $20 \mathrm{e} ; 1 / 4 \mathrm{lb}, 50 \mathrm{e} ; 1 \mathrm{lb} ., \$ 1.75$, postpaid.

MAMMOTH SILVER KING-The largest white Onion; grows to a remarkable size, a verage diameter is from 5 to $7 \frac{11 / 2}{2}$ inches. Pkt., 5c; 0z., $25 \mathrm{c} ; 1 / 4 \mathrm{lb}$, 7 c 11 1b., $\$ 2.50$. postpaid.

IMUDA-A large quick growing red variety; very tel der and jarge yielder and a good keeper. Pkt., 5e; oz., 20c; 1/a lb., 75c

IARGE RED WRTHERSFIELD-This is the standard red variety and a favorite onion in the East, where immense crops are grown for shipment. It
is very extensively grown for home garden use as well as the market. Pkt. 5e is very extensively grown for home garden use as well a
oz.. $20 \mathrm{c}: 2$ oz.. $35 \mathrm{c} ; 1 / 4 \mathrm{~b} . .50 \mathrm{c} ; 1$ lb., $\$ 1.75$, postpaid.

WHITE SIIVER SKIN ONION-This is a superior stock. Its delicate, nild Havor, stately form, large, handsome size, pure white color make it a most wonderful variety for the table, the most profitable for market and shippinin. Flant are of an extremely thin neck and sure to ripen earls; should be harested a soon as ripened and dried in the shade to preserve

IIAMMOTY YELLOW SPANISH OR PRIZETAKER - A very handsome late or main crop Onion of the largest size and nearly globular in form, usually

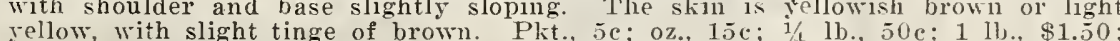
rellow, with slight tinge

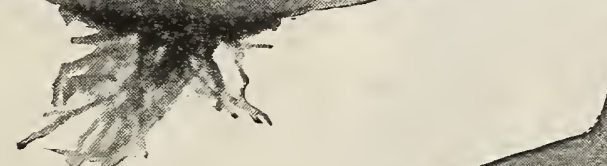
Although the first of the red sorts to ripen, the bulbs are firm an keep remarkably well for so early a variety. Pkt.. 5e
oz., 20c; 2 oz., 35c: 1/t lb., 50c; 1 lb., $\$ 1.75$, postpaid. WHITE PORTUGAL-Flesh is very nild and sweet and the thin skin a clear, silvery white. Bulbs should be gathered as soon as ripe and carefully dried. Pkt., $5 \mathrm{c} ;$ oz., $25 \mathrm{c}$; $1 / 4$ lb., 60e; $1 \mathrm{lb}$. WHITY BRRIIUDA-The best, earliest and most prolific oinon grown; produces a large, beautiful that onion of excellent flavor. Pl.

YELLOW DANVRRS-Productive and early main crop variety of medium size; skin light coppery yellow; flesh creamy white, mild; bulbs flattened ret quite thick. Plit., 5e; oz., $20 \mathrm{c} ; 2$ oz. $35 \mathrm{c} ; 1 / \mathrm{ib}$ que; 1 lb., $\$ 1.50$, postpaid.

AUSTRAIIAN BROWN-Popular variety in California because of its keeping qualities. Bulb me dium sized nearly spherical; reddish-brown; rathe WHITE SILVER SKIN ONION entirely. This applies to all varieties except the Potato Onion, which should be planted in rows 15 inches apart anc 9 inches apart in rows and then cover with about one inch of soil. All varieties can be set out in the fall as well as in the spring. Fall plantings of onions are succeeding very well in the South and should be more generally practiced.

YELLOW РОтАTO-A mild sellow sort, growing in clumps, producing no seed. Quart, 25e; 1 gallon, 80c; 1 peck, $\$ 1.50 ; 1$ bushel, $\$ 5.00$, by express or freight. By parcel post, add $5 \mathrm{e}$ per quart postage.

WHITE SETS-One quart, 20c: 1 gallon, 50c; 1 peck, 85c: 1 bushel, $\$ 2.7 \mathrm{~J}$ by express or freight. By parcel post, add 5e per quart postage.

WHITE MULTIPLYING-One quart, $35 \mathrm{c} ; 1$ gallon, $85 \mathrm{c} ; 1$ peck, $\$ 1.50$ : 1 bushel, $\$ 5.00$; by express or freight. By parcel post, add $5 \mathrm{c}$ lei quart postage.

RED-One quart. 15e; 1 gallon, 40c: 1 peck, $75 \bar{c}$ : 1 bushel, $\$ 2.50$, hy express or freight. By parcel post, add $5 \mathrm{e}$ per quart postage.
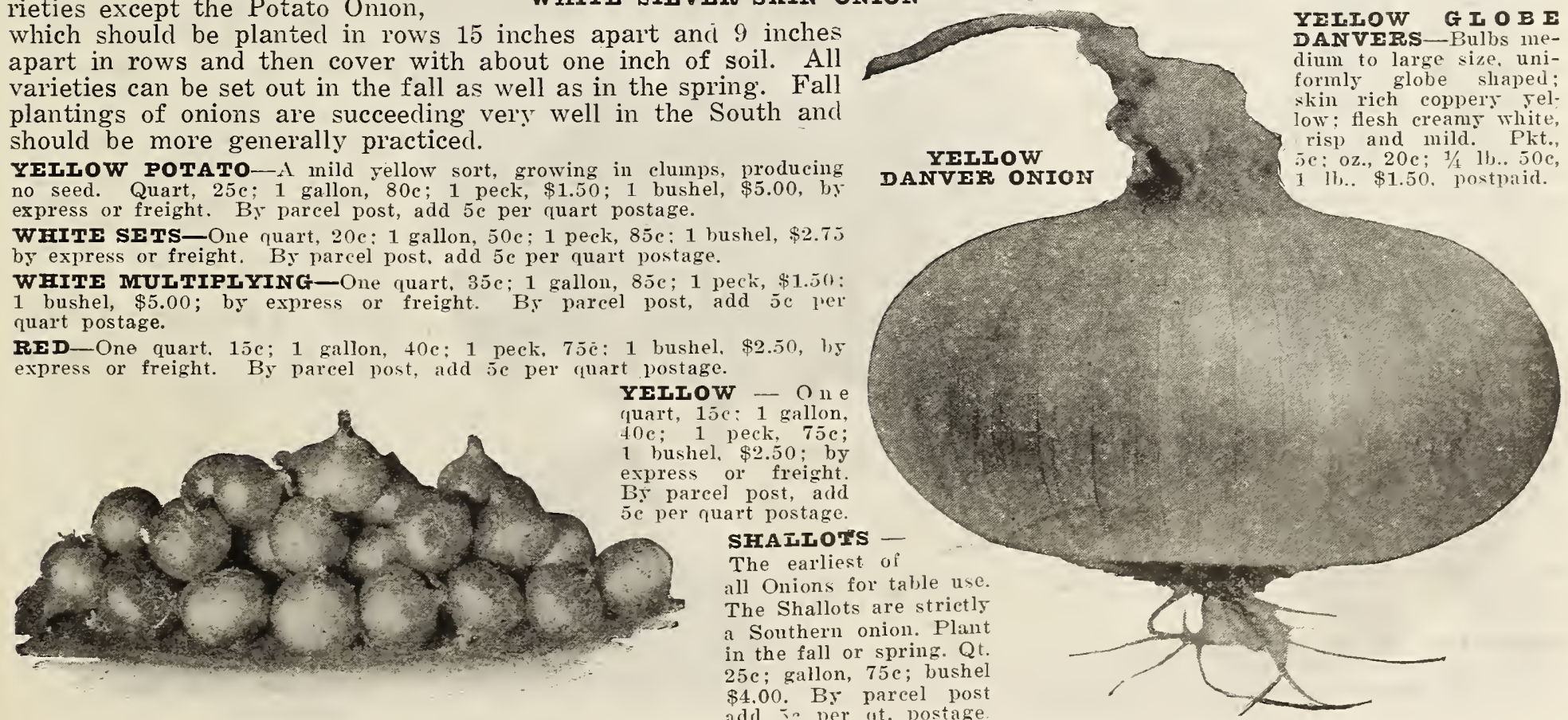

YRILOW G I O B E dium to large size, uniformly globe sliaped kin rich coppery se SHALIOTS all Onions for a Southern onion. Pl in the fall or spring. Q $25 \mathrm{c}$; gallon, $75 \mathrm{c}$; bu po 


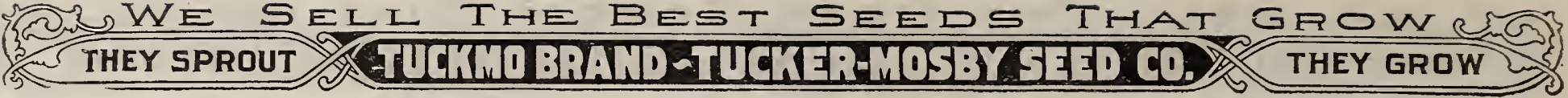

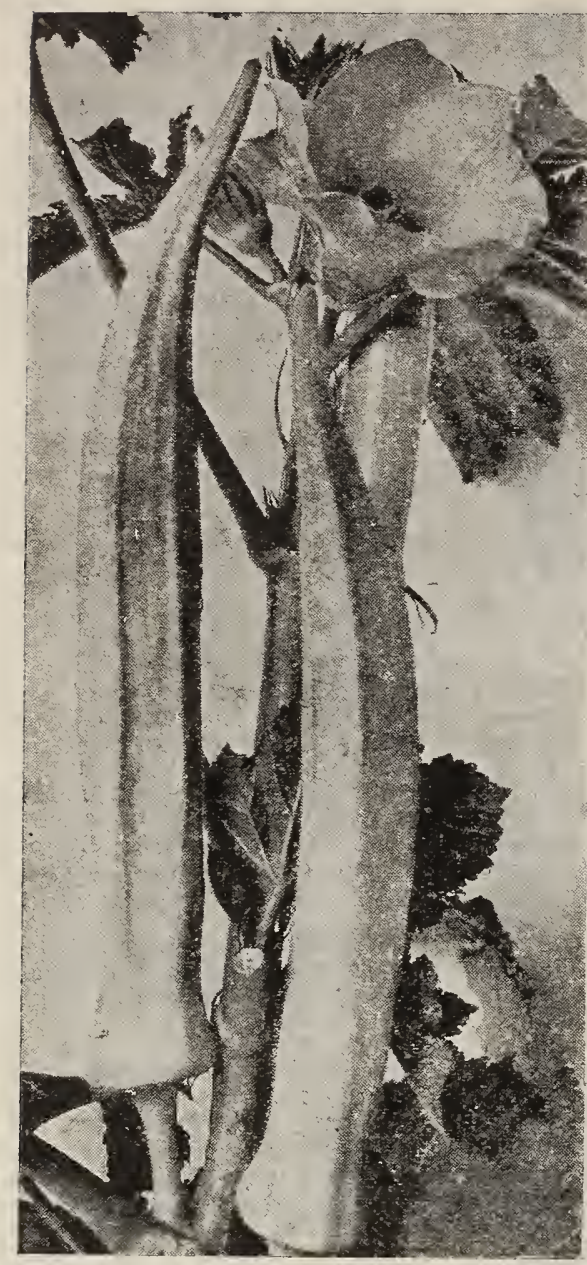

WFITP VEIVFI

\section{PARSLEY}

Parsley is so easily grown and useful for so many purposes that every garden no matter how small, should have a supply. A very pretty effect is produced if parsley is used as an edging for flower or vegetable beds, and when it is pulled or cut, shoots out again quickly and keeps up a delightful fresh, green edging all the season. In the winter, parsley can be very profitably grown under glass.

Soak the seed in water a few hours, and sow in rich soil early in spring, in rows a foot apart and cover lightly. Parsley is slow to germinate and it is sometimes three or four weeks coming up. One ounce will sow one hundred and fifty feet of drill.

IARGE DOUBIF CURIED-This is an excellent variety, dwarf in habit; grows very compactly and stands the winter better than the plain. Leave and stands the winter better than the plain. Leaves crimped or curled and used principally as a garnish for the table. Pkt., 5c; oz., 10c; $1 / 1$ lb., $30 \mathrm{c} ; 1 \mathrm{lb}$., $\$ 1.00$, postpaid.

PIAIN OR SINGIE-Dark color; very hardy; much used for flavor ing. The leaves are plain or smooth Pkt. $5 \mathrm{c} ; 0 \mathrm{z}, 10 \mathrm{c} ; \mathrm{I} / 4 \mathrm{~b} ., 30 \mathrm{c}$ : 1 lb., $\$ 1.00$, postpaid.

CFAMPION MOSS CURIFD-Dense foliage; fine, more densely crimped and curled than others. Leaves very large and tender. Can be used for outdoors or greenhouse culture. (See illustration.) Pkt. $5 \mathrm{c}$; 0z., 10c; 1/4 lb., 30c; 1 lb., \$1.00, postpaid.

\section{OKRA or GUMBO}

The young seed pods are used in soups, stews, catsup, etc. Highly esteemed in

Six or eight quarts of shelled nuts to the acre. They are best adapted for light 作 each hill; cover about two inches.

TFNNESSE RED-Especially adapted to our land. The nuts contain three kernels each the productive. $1 \mathrm{lb}$., $25 \mathrm{c}$, postpaid. By freight or express, $1 \mathrm{lb} ., 20 \mathrm{c} ; 20 \mathrm{lbs}$. (he peanut growin
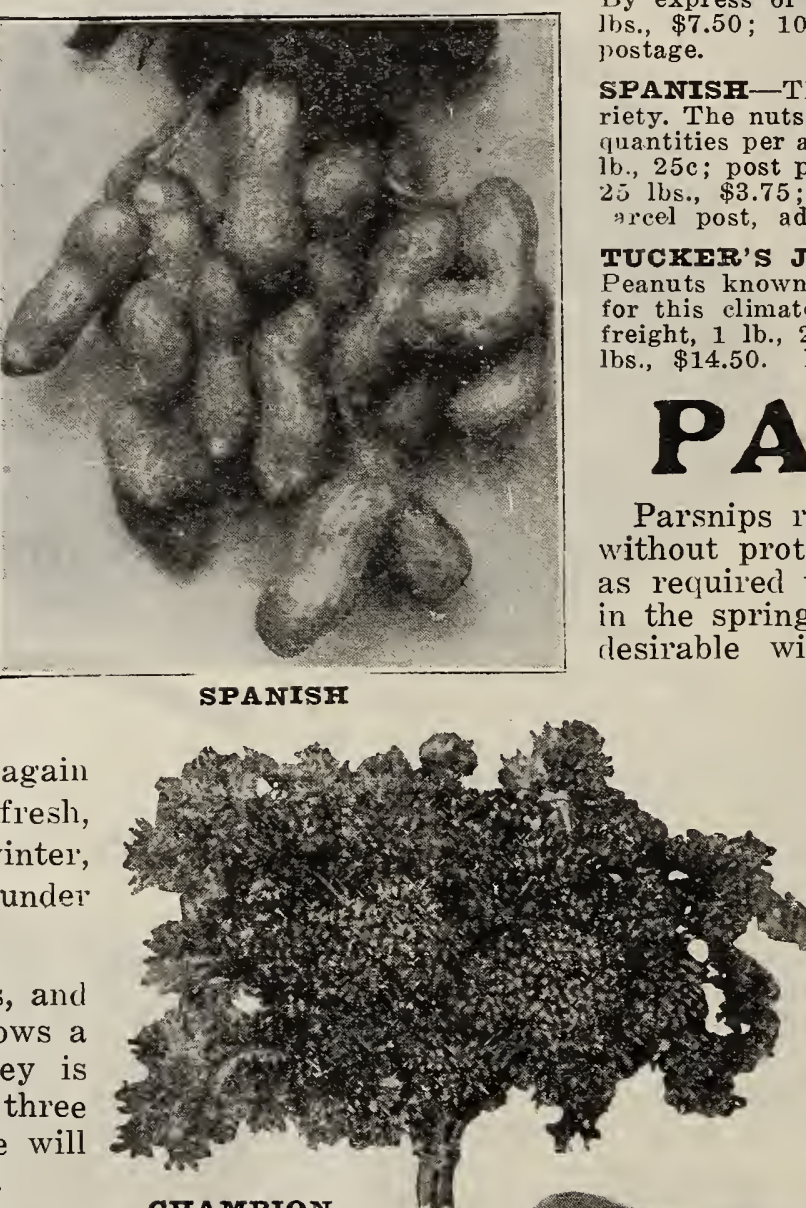

chamion CFAMPION postage.

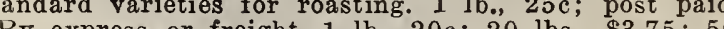
By express or freight, 1 lb., $20 \mathrm{c} ; 20$ lbs., $\$ 3.75 ; 50$
lbs., $\$ 7.50 ; 100$ lbs., $\$ 14.00$. By parcel post, add

SPANISH-The earliest, but also the smallest variety. The nuts are solid and well filled, yielding large quantities per acre. The best sort for fattening hogs. lb., $25 \mathrm{c}$; post paid. By express or freight, $1 \mathrm{lb} ., 25 \mathrm{c}$ 25 lbs., $\$ 3.75$; 50 lbs., $\$ 6.00 ; 100$ lbs., $\$ 11.00$. By arcel post, add postage.

TUCKRR'S JUMBO-The largest white variety of Peanuts known, exceedingly productive; well adapted for this climate. $1 \mathrm{lb}, 30 \mathrm{c}$, postpaid. By express or freight, 1 lb., $25 \mathrm{c} ; 20$ lbs., $\$ 3.50 ; 50$ lbs., $\$ 7.50 ; 100$ lbs., \$14.50. By parcel post, add postage.

\section{PARSNIPS}

Parsnips remain in the ground all winter, without protection, and can be dug for use as recuired until they begin to run to seed in the spring. They are, altogether, a most lesirable winter vegetable, and should be much more largely grown than at present. A rich, sandy loam, deeply worked is the best for Parsnips. Sow in April, in drills 18 inches apart, corering lightly. Parsnip seed is very ering in intly. Parsnip seed is rery slow in germinating, especially when the ground is dry. When the plant are two inches high, thin out to 4 to 6 inches apart. One ounce of to six pounds to the acre.

SUGAR OR HOIIOW CROWNThe very best sort in existence. A large yielder of the finest quality. Pkt., 5c: oz., 10c; 1/4 lb., 30c: lb.. $\$ 1.00$. postpaid. 


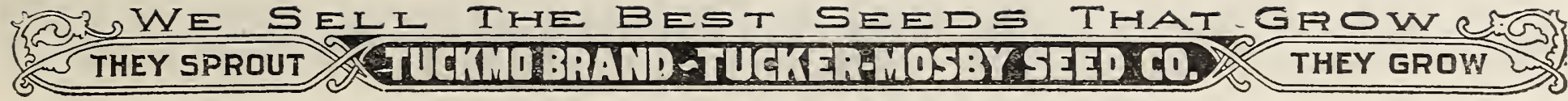

\section{GARDEN PEAS}

Peas may be planted from February to June and in August for fall crop sowing extra early varieties. Sow one quart to 75 feet of drill or 2 to 3 bushels per acre. The smooth varieties are the hardiest and should be planted first. The seed are usually sown thick in double rows, and these double rows constituting one row, should be about $31 / 2$ to 4 feet apart. Cover seed 2 to 3 inches. Cultivate often, especially in dry weather. It is not necessary to provide support for the dwarf varieties. Peas grow fairly well in poor soil, but a little fertilizer will greatly increase the yield. Well rotted stable manure is good. They should be kept clean and earthed up twice during growth.

BIISS' IVIRBFARING-The vines are stout, of medium height, about two and one-half to three feet, bearing at the top six to ter good-sized pods, about two and one-half to three incles long. If these are picked as they mature and the season and soil are favorable, the plant will throw out branches bearing pods which will mature in succession, thus prolonging the season. The peas are large and wrinkled, cook very quickly, are tender, of superior flavor and preferred by many to any other sort. Pkt., $15 \mathrm{c}$; $1 / 2$ lb., $20 \mathrm{c} ; 1 \mathrm{lb}$., $35 \mathrm{c} ; 2$ lbs. $60 \mathrm{c} ; 5$ lbs., $\$ 1.25$, postpaid. By express or freight $20 \mathrm{c}$ per pound. AMEIR A new and valuable strain of the popular Alaska Pea, the distinctive superiority being that it
makes much larger pods and is more prolific. The vines makes much larger pods and is more prolific. The vi
grow about the same height, but the superiority in size of pods and yield makes it a more valuals a quisition. Pkt., $15 \mathrm{c} ; 1 / 2$ lb., $20 \mathrm{c} ; 1 \mathrm{lb}$ $35 \mathrm{c} ; 2$ lbs. $60 \mathrm{c} ; 5$ lbs. $\$ 1.25$, postpaid. By express or' freight, 20 cents per pound.

GRADUS OR PROSPERITY (Wrinkled)-This is the earliest large poided pea in cultivation. The peas are tender and sweet, of extra large size pods, averaging 4 to $4 \frac{1}{2}$ inches long and contain from eight to ten peas of enormous size and excellent quality. Pkt. 15c; 1/2 lb., 20c; 1 lb.. $35 \mathrm{c} ; 2$ lbs., 60c; 5 lbs., $\$ 1.25$, postpaid. BI express or freight 20 c per pound.

EARIY ATASKA (Not Wrinkled)-One of the first early peas grown; extremely early, very hardy and most prolific sort. This variety is very dis. tinct from anything else. The dry peas being a bright green color and also the vines and rods. They will carry farther without injuring their bright green color than any other sort. Our stocks are genuine. Pkt., $15 \mathrm{c} ; 1 / 2$ lb., 20c; 1 lb., $35 \mathrm{c}$; paid. $\mathrm{By}$ e 5 lbs.. $\$ 1.15$, postper pound.

THOMAS IAXTON-A cross hetween Gradus and one of the extra early sorts. It ripens within a day or two of the ear. liest round varieties and is extremely productive. The pods are very large and contain seven or eight large-sized wrinkled peas of the ninest flavor. It is darker than the Gradus and hardier in constitution: height three feet. Pkt., 15c; $1 / 2$ lb., 20c; 1 lb., 35c; 2 lbs., 65c; freight or express. 20 cents per freight
pound

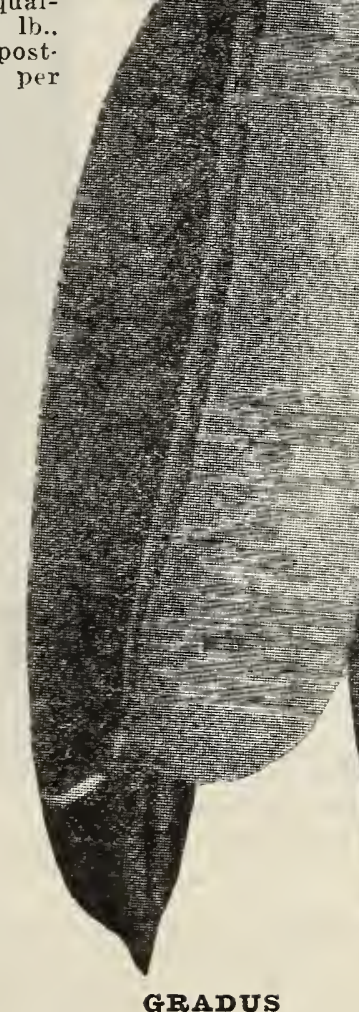

GRADUS

MFITING SUGAR (Edible Pods)-We consider this the best of the edible-podded sorts, in which the pods are used when half grown and are cooked in the same way as snap beans. The pods of Melting Sugar are very large, 4 to $5 \frac{1}{2}$ inches long. broad, often curved or twisted, and when young stringless, very tender, finely flavored. The variety we offer, sometimes called Mammoth Melting Sugar, is rather late maturing, very prolific, strong growing, about four to five feet high, with large light colored foliage. growing, about four to five feet high, with large light colored foliage. Pkt., 15c; 1/2 lb., 20c; 1 lb., 35c; 2 lbs., 65c; 5 lbs., \$1.25, postpaid. By freight or express, $20 \mathrm{c}$ per pound.

THE ADMIRAI-The vines of this exceptionally hardy, second early variety are tall and vigorous, about four feet high. The pods are usually bol'ne in pairs, are curved, bright green, about two and three-quarters inches long, and are crowded with six to nine peas of good quality and deep green color. Seed wrinkled, of small.

medium size. Pkt., $15 \mathrm{c} ; 1 / 2$ lb., $20 \mathrm{c} ; 1 \mathrm{lb} ., 35 \mathrm{c} ; 2 \mathrm{lbs} ., 6$
$\$ 1.10$, postpaid. By express or freight. $18 \mathrm{c}$ per pound.
FIRST AND BEST-This is the earliest and most even strain white, extra early peas, maturing so well together that sometimes a single picking will secure the entire crop. The vines are vigorous and hardy, of medium height, about two and one-half to two and three-fourths inches long, each containing five to seren medium sized smooth peas of fair quality. Seed small, smootl, yellowish whitePkt. 15c; 1/2 lb., 20c; 1 lb., 35c; 2 lbs., 60c; 5 lbs.. \$1.15; postpaid. By freight or express, 18c per pound.

IARGE WHITE MARROWFAT (Not Wrinkled)-. vers tall vigorous growing sort, exceedingly prolific; pods very large, of good quality. This variety is very hardy, standing more heat and cold than any other sort. Pkt., 15c; $1 / 2$ lb. By freight or express, $16 \mathrm{c}$ per pound

IARGE BIACKEYE MARROWFAT (No Wrinkled) - An excellent, tall variety, about 5 feet high. It is a very prolific bearer of large pods about three inches long. Seed large, smooth round, light creamy yellow with black eye. One of the very best of the Marrowfat sort. Pkt., 15c $1 / 2$ lb., 20c; 1 lb., 30c; 2 lbs., 55c; 5 lbs. $\$ 1.10$ postpaid. By freight or express. 16 per pound.

ALDERIMAN-This is in many respect the very best early main crop variety of the valuable Telephone type. The vines are tall growing, about four and one-half to five feet high, dark green, vigorous and exceedingly productive. The pods are of largest size, often five to five and one-half inches long, dark green. Pkt., 15c; $1 / 2$ lb., 20c 1 lb., 35c; 2 lbs., 65c; 5 lbs., $\$ 1.25$, postpaid. By express or freight, $20 \mathrm{c}$ per pound. TOM THUMB-An older sort of white smooth peas; very dwarf growth, averaging about ten inches. Very hardy, but not so prolific as the above mentioned sorts and raluable only on 20c; 1/2 pound, $25 \mathrm{c} ; 1$ pound, $40 \mathrm{c} ; 2$ pounds, $70 \mathrm{c} ; 5$ pounds, $\$ 1.50$, postpaid By express or freight.

IAXTONIAN

- This handsome wrinkled nea is the lare. est podded

the dwarf va rieties on ou list. The beau tiful dark green pods are siru ir slrape. splen did quality, are nearly as larg in size aud often mature a little earlier. The vines are vigorous and productive, averfoliage dark green; pods about four inches in length. Seed light green, large, wrinkled, flattened, irregular in shape. Packet, 15c; 1/2 pound, $20 \mathrm{c}$ $\$ 1.25$, postpaid. $\mathrm{By}$ express or freight $20 \mathrm{c}$ per pound.

TUCKMO BRAND SEEDS are the very best that can be grown. When planting seeds of this quality jou are sure of a

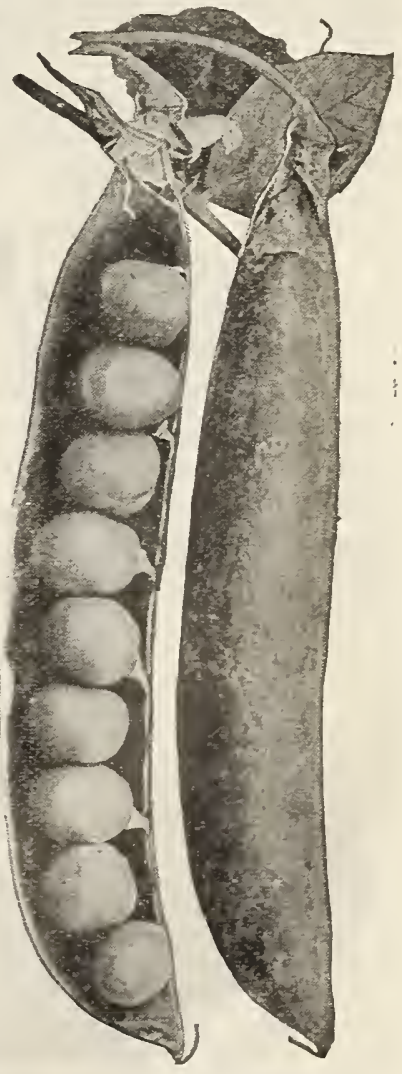

AIDFRMAN 


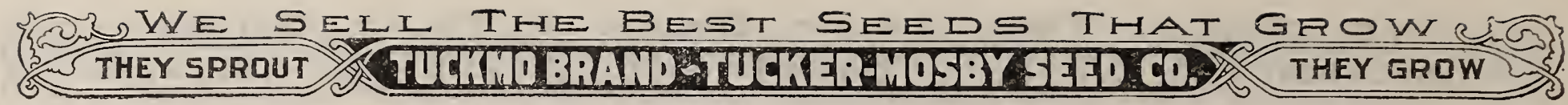

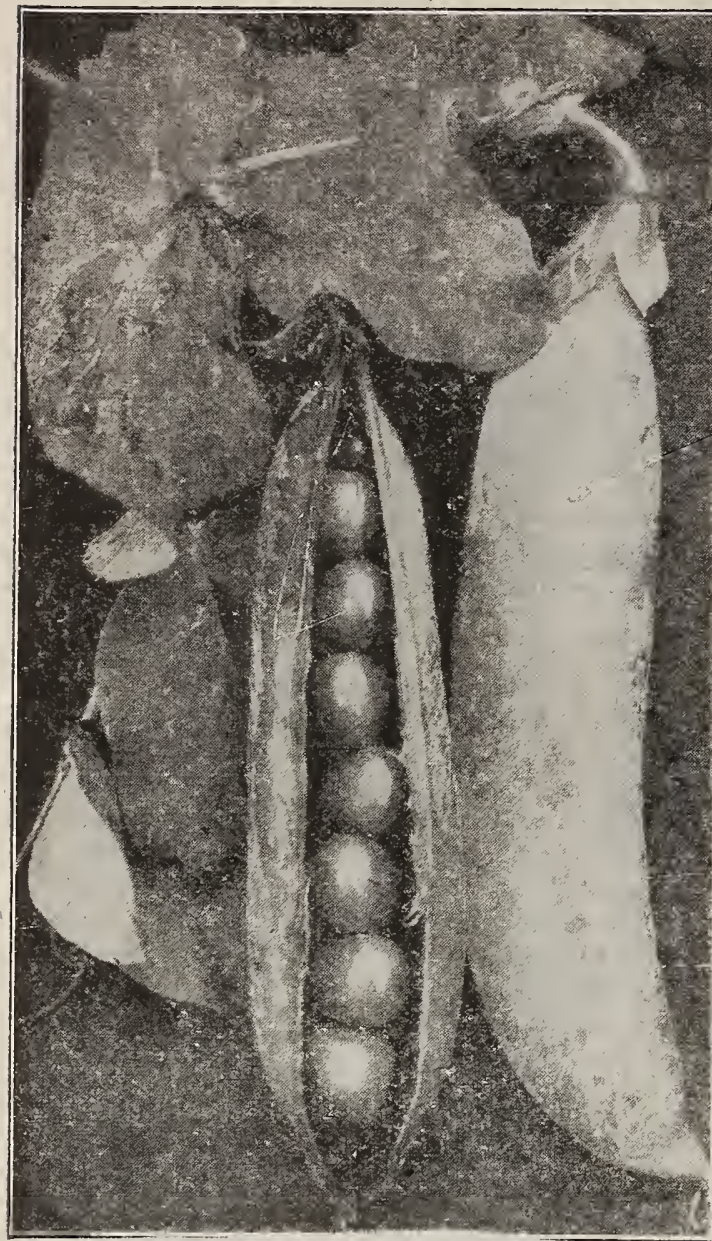

CKAMPION OF ENGLAND

POEIADX OR EIG DINNER Strong. luxuriant dark foliage, bearing pods medium green it in color, $3 \frac{1}{2}$ inches in length Broad and pointed at the ends. No variety known will produce more porks, and no pods could possibly shell out better. The Potlach is a variety from which any one may expect great things. Fit for table use sixty-one days from planting. Seed green and
wrinkled, large in size. Pkt.; $15 \mathrm{c} ; 1 / 2$ lb., $20 \%$;
1 lb. 35c; 2 lbs., 65c; 5 lbs.. $\$ 1.25$, postpaitl. By

NOTr'S EXCEISIOR-Although a few days later than the American Wonder, the pods will average fully one-third larger. For wrinkled peas they are remarkably hardy, and can be planted almost as early as the smooth sorts. Dwarf in habit, of vigorous 1 lb., 35c; 2 lbs., 65c; 5 lbs., $\$ 1.25$, postpaid. By express or freight $20 c^{2}$ per pound. AMERICAN WONDER-One of the best known of the dwarf early wrinkled peas, which has long been a favorite for family use; vines growing about nine inches high, are strong, robust and remarkably productive. Peas delicious, small and very sweet. Pkt., 15c: 1/2 th., 20c; 1 lh., 35c; 2 lbs., 65c; 5 lbs., \$1.25, post $20 \mathrm{c}$ per pound.

IMPROVFD STRATAGIM-One of the best of the large-podded, semi-dwarf main crop varieties. The vines are about two to two and one-half feet high, with medium dark green foliage. The pods are very large. often four and one-quarter to four and one half inches. long. pointed, dark green and uniformly filled with very large, dark green peas of the finest quality. Pkt., $15 \mathrm{c} ; 1 / 2$ $\$ 1.25$, postpaid. By express or freight, $20 \mathrm{c}$ pound.

CHAMPION OF ENGIAND-A stand ard, very productive, main crop variety, universally admitted to be one of the richest and best flavored of the late peas. The vines are tall, about four to five feet high. The pods are large, about three inches long. The seed is light green and wrinkled. We consider this rariety one of the best of its kind, either for the lome garden, or for market gardening. Pkt., 15c; $1 / 2$, 1 lb., 35c; 2 lbs., 65c; 5 lbs., $\$ 1.25$, post paid. By express or freight, $20 \mathrm{c}$ per pound.

M'IEAN'S IITTIE GEM- (1 1/1 feet)A wrinkled variety of similar habit to the Earliest Dwarf and maturing a few days later, or fifty to fifty-five days after planting. Pods tivo and one-half to three inches in length, round and filled with peas of de licious flavor. In fact, they have the same sugary flavor as the late wrinkled sorts and the additional merit of earliness. A pea that alwars gives entire satisfaction. Pkt. $15 \mathrm{c} ; 1 / 2$ lb.. 20c; 1 lb.. $35 \mathrm{c} ; 2$ lbs., $65 \mathrm{c}$; freight, $18 \mathrm{c}$ per pound.

TrIEPHONE-This has become the leading pea with market gardeners whose trade appreciates fine appenrance and high qualty. The vines are tall and vigorous, growng four feet high, with large, coarse, light colored leaves and producing an abundance of pointed pods of largest size, often four and one-half to five inclies long; attractive rright green, filled with very large peas, which are tender, sweet and of excellent lavor. Pkt. 15c; $1 / 2$ lb. 20c: 1 lb. $35 \mathrm{c}: 2$
bs. 6.je: j lbs. $\$ 1.25$, postpaid. ress or freight $20 \mathrm{c}$; per pound.

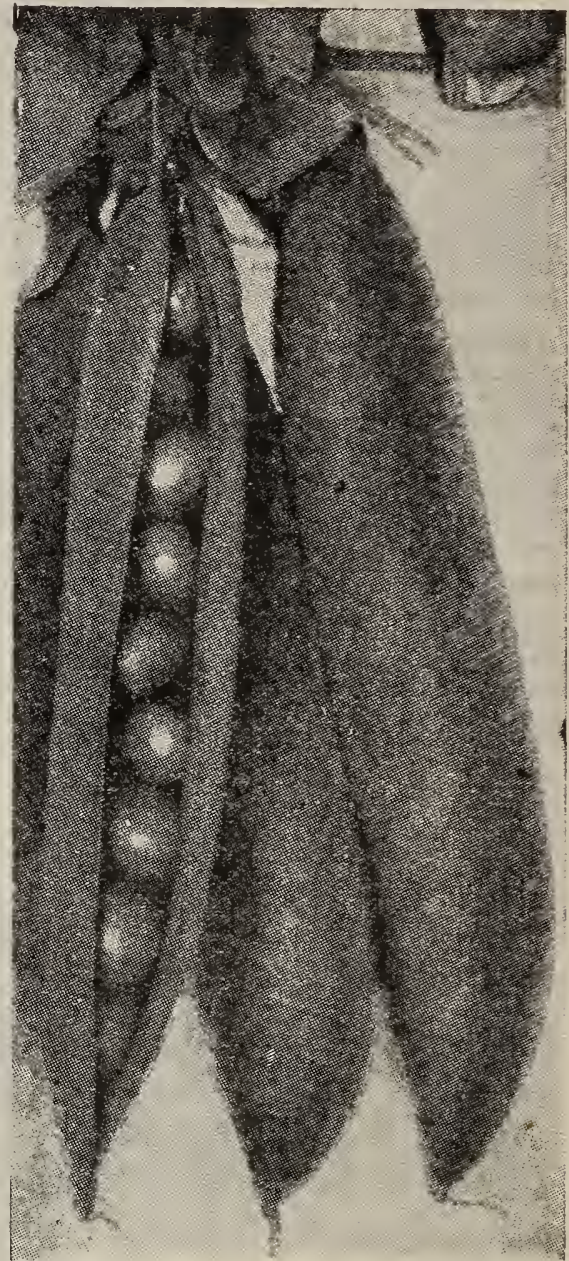

ALASTA, EARIY VARIETY

\section{SEED SWEET POTATOES}

All sweet potatoes will be shipped about the middle of March. The weather before that time is entirely too cold to ship. We ship in good condition, and do all in our power to get them to you in good order. Sweet Potatoes are poor shippers. Our responsibility ceases upon our delivery to the railroad company in Memphis, Tenn. We will not be responsible for delays or damaged conditions on arrival. All prices given below include packing f. o. b. Memphis. Purchaser must pay express or freight charges.

WANCY HAIT-Lnown also as Providence, also Norton. Ahrost a buncl potato, easily cultivated; leaf pointed; color is reddish, skin is reddish, stem ditto. Late July planting from vines makes good, large potatoes; elliptical like a beet in shape; a poor land potato. Round. smooth, very early-60 days after planting. Very good for table. Productive, good keeper. Grower says: "I plant $31 / 2$

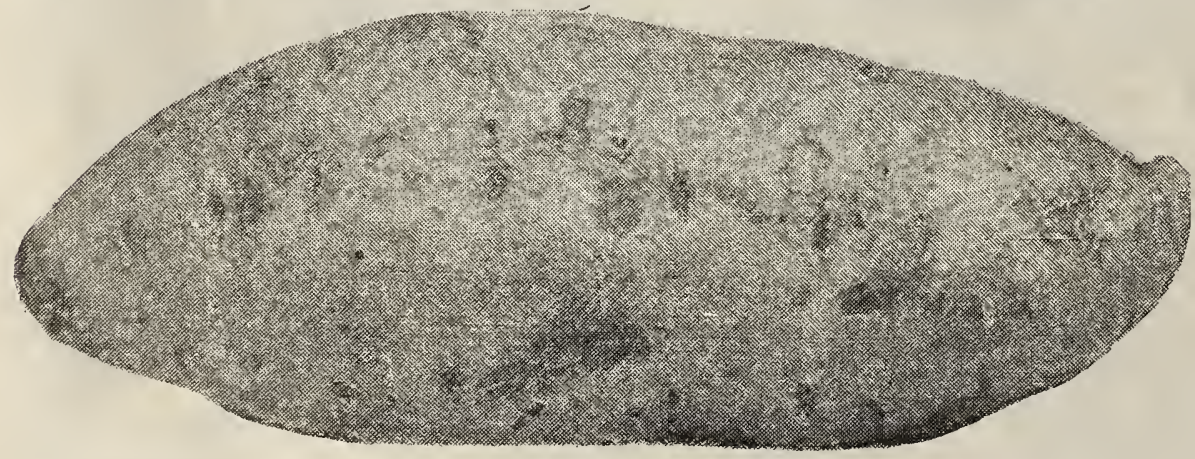

NANCY HATI SWEFT POTATO feet rows and 14 inches in row. I made 200 busliels per acre-rellow as gold, cook soft and sweet-good keepers." Growers pronounce this potato as being one of the most delicious eating potatoes known. Peck, $65 \mathrm{c}$; bushel, $\$ 2.00$.

PORTO RICO YAM-Known, too, as Golden Beauty and New Providence. A sensational potato. wrongly called Cuban Yam. New; deep yellow Tesh: pink skin; fine quality; sprouts earlier than Nancy Hall; matures quicker and larger than Nan cies. It is one of the sweetest sweet potatoes that we have ever tried. Peck, 65c; bushel, \$2.00.

FIORIDA YAM-The Florida Yam is earlier, lias deeper yellow flesh and is more productive than the Nancy Hall, and in quality fully equal to the latter variety. They will make 300 bushels to the acre and come early, and when you have a deep Jeliow meated variety that is ready for the market early August it will make the grower modey. Peck, 6in
bushel, $\$ 2.00$. 


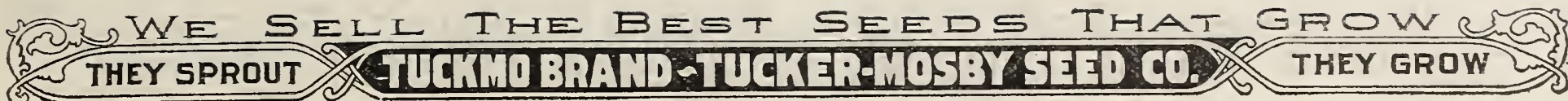
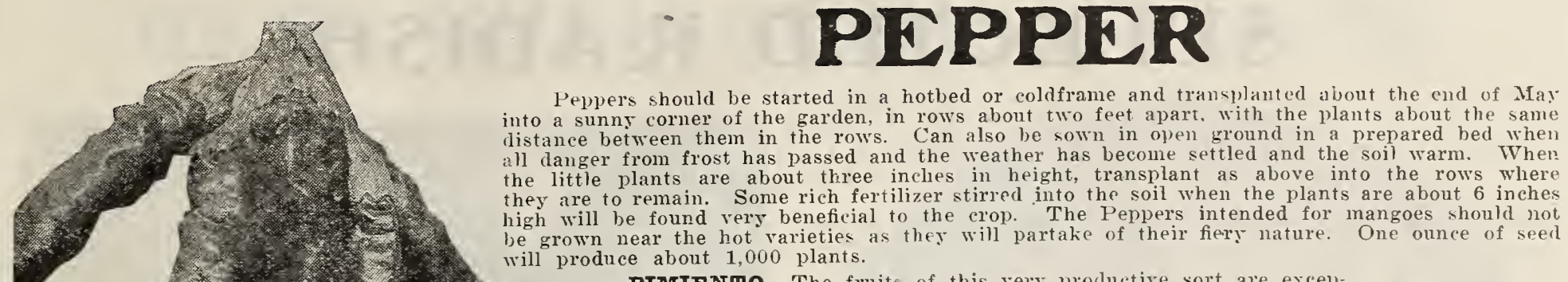

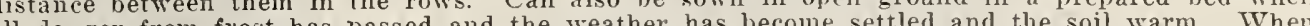
litle plants are about three incles in height, transplant as above into the rows where

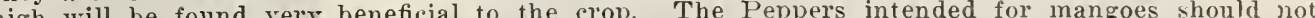
be grown near the hot varieties
will produce about 1,000 plants.

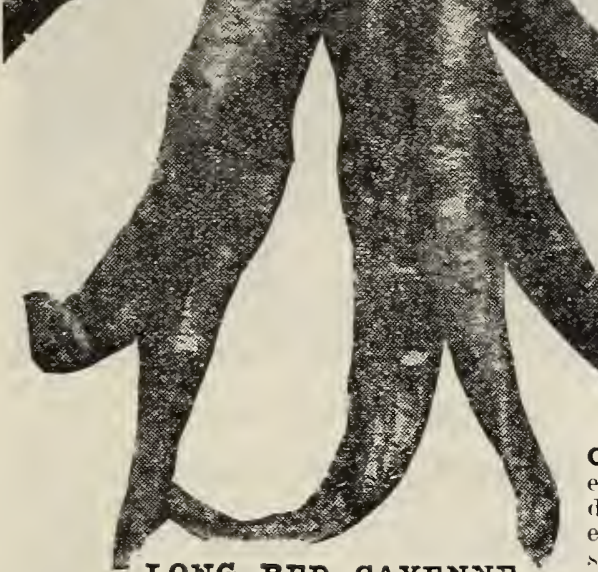

PIMIENTO-The fruits of this very productive sort are excep-

tionally smooth and glossy, of good size

tractive color. The flesh is vel.

very fine flavor. Desirable not only for salads and stuffed peppers but it is also the sort used largely by canners. The plants are vigorous and upright, about two to two and one-half right, about two to two and one-half feet high, with short, broad, dark green leares. The fruts are dee
rreen when young. becoming deep red $0 \% .45 \mathrm{c} ; 1 / 4$ lb.. $75 \mathrm{c} ; 1 \mathrm{~b} ., \$ 2.75$.

RFD CHFRRY-Small round fruits very prolific. Pkt. 5c; oz. 25

CHINESE GIANT-The largest sort that grows

normous, sweet flavored pods, thick, crisp flesh and delightful flavor; plants bushs, coming to hear tuffing. Pkt. $5 \mathrm{c} ; 0 \mathrm{z} .35 \mathrm{c} ; 1 / 1$ ib. $\$ 1.25 ; 1 \mathrm{lb}$. $\$ 4.00$ postpaid.

IONG RED CAYENNE-A long, slim pointed pod. When ripe, of a bright red rolor; extremely strong and pungent. Plet. $5 \mathrm{c} ; 0 \mathrm{0z} 25 \mathrm{c}$; $1 / 4$ lb., $75 \mathrm{c} ; 1 \mathrm{lb}$., $\$ 2.75$, postpaid.

IARGI BIII, OR BUII NOSE-The color is deep green when fruit is roung, bright erim son when ripe. Pkt. 5c; oz. $25 \mathrm{c} ; 1 / 4$ lb., $85 \mathrm{c}$; 1 lb., $\$ 3.00$, postpaid.

RED CREOIE-Very hot, small, thin: coral red color. Pkt. 5c; oz. 25c; 1/4 1b. $75 \mathrm{c}, 1 \mathrm{lb} . \$ 2.75$. RUBY KING - This variety grows to an enormous size, from $4 \frac{11}{2}$ to 6 inches long, and from 3 to $t$ inches thick. The flesh is verr thick and tender, mild and pleasant to the taste; it is a fine sort for stuffing and also makes excellent salad. Pkt., 5c; oz., 25c; 1/4 th. 85c; 1 lb., $\$ 3.00$, postpaid. SWEET MOUNTAIN-One of the large sorts; very thin skinned, RED CrIII-A late variet

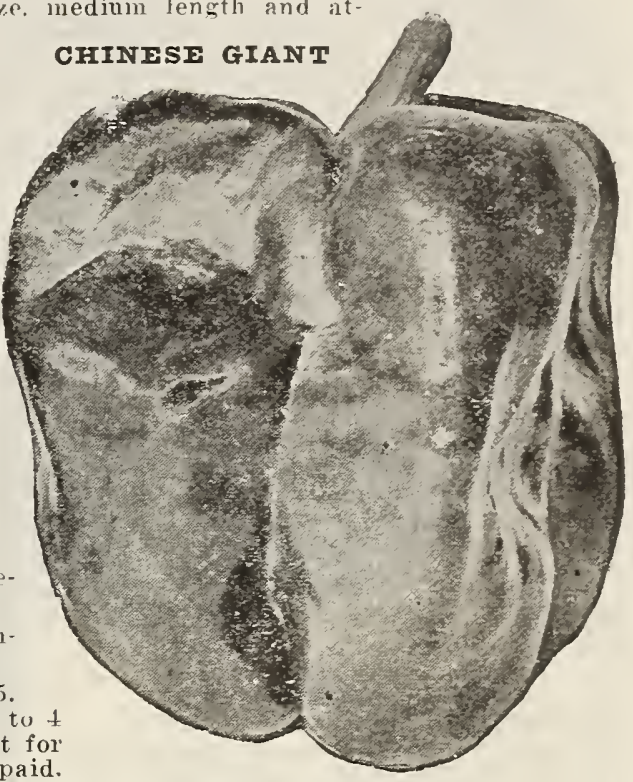
sweet and mild flavored; much used for stuffed pickles. Pkt., 5c; inches long; exceedingly pungent

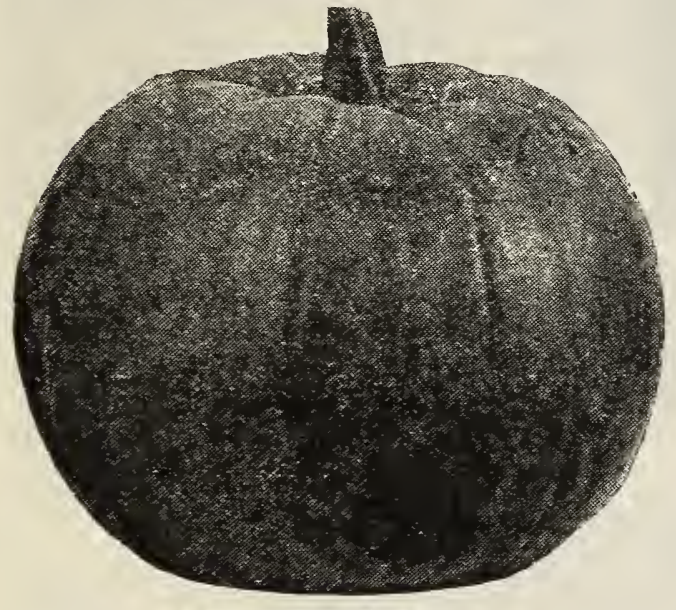

PUMPKIN

Are usually planted in cornfields to grow with corn for winter feed. Considered a very healthy and most nutritious food for cattle in winter. In addition to their value as a stock food, they are also largely used for culinary purposes, the finer grained varieties making excellent pies.

Plant in May in hills eight feet apart, mixing a shovelful or two of welllotted manure in each hill. Put eight or ten seeds in each hill and cultivate till the vines get strong, when they should be thinner out, leaving two or three of the strongest plants in each hill.

KINTUCKY FIEID-A very popular Southern sort. large and flattened. A wonderful keeper. A good stock variety also a valuable eating and

CONNECTICUT FIFID-A large, rellow variety with a

KENTUCKY FIEID purd shell. Excellent for stock feeding. The hardiest of all pumpkins and enormously prod

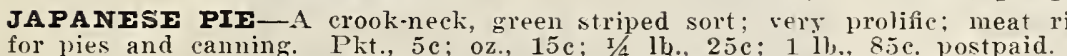

GOIDEN OR YEIIOW CUSHAW-Similar in every way to the Green Striped Cuslua except in color, being a dark golden yellow; very sweet. Pkt., 5c; oz., 15c; 1/t 1b.. 25c; 1 lb., $85 \mathrm{c}$.

TENNESSE SWFET POTATO-Flesh bright yellow and rery thick, fine grained and sweet, large, round and slightly flattened. Adapted for Southern soil and climate. Pkt., 5c; $0 \%, 10 \mathrm{c}$; 1/s 1b., $25 \mathrm{c} ; 1 \mathrm{lb} .$, LARGE CHEFSE-Superior to the field varieties, as it is excellent for table use as well as stock feedin GRE for pies; shape flat, skin mottled light green and rellow. Pkt., 5c: oz., 10c; 1/4 lb., 20c; 1 b., 6.3 . Pkt., 5c; oz., 15c; 1/1 lb., 25c; 1 lb.. 85c. postpaid.

\section{Salsify or Vegetable Oyster Plant} and are served in a rariets of wars. The flavor is similar to the orsters. Salsify succeeds best in a lich well enriched soil. which should be stirred to a good depth. Coarse and fresh manure should be avoided. general culture recommended for parsnips. The roots are perfectly hardy and may remain out all winter. but should be dug early in spring, as thes deteriorate rapidly after growth commences. Frost does
injure the roots, but before the ground freezes a nuantity for winter use mas be stored in a pit injure the roots, but
in a very cool cellar.

MAMMOTH SANDWICH ISIAND-This variety is large and strong, growing long, smooth, white tapering roots, and is less liable to branch than the other sorts. Tops grassy. It is invaluable fo
market gardener's use. Pkt., 5c; 1 oz., 15c; 2 oz.s., $25 \mathrm{c}$; 1/. lb., $40 \mathrm{c} ; 1$ 1b., \$1.50, postpaid.

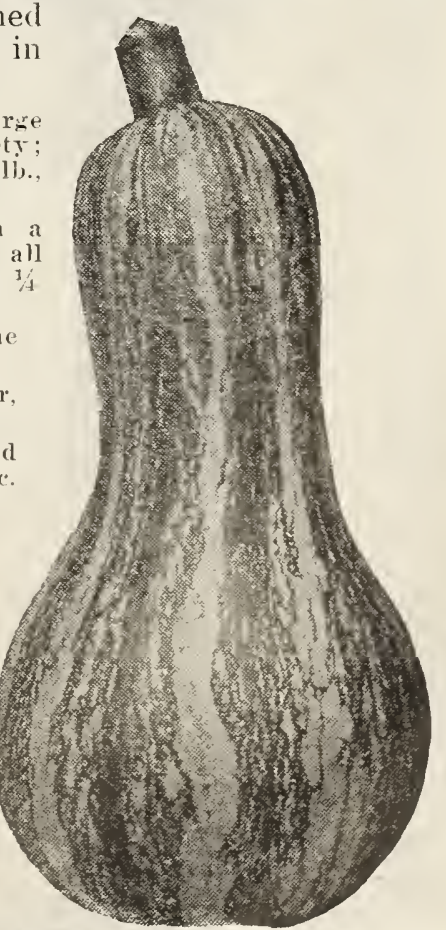

GREEN STRIPED CUSHAW 


\section{SELECTED RADISH}

One ounce of seed will sow 100 feet of drill, ten or twelve pounds to the acre. Sow in January or February in hotbeds, and the inust have plenty of ventilation and moisture. Out of doors, sow from March to Septeinber. Radishes nust be grown quickly to be tender and crisp, and quick growth requires rich soil and plenty of moisture.

FARIT SCARIEY TURINIP, WHITY TIPPID-One of the best radishes for home garden and a great favorite in large market for early planting outdoors. It is but little later than Early Scarlet for early planting outdoors. It is but little later than Early Scarlet where extreme earliness and small tops are not the chief considera. wions. The roots are nearly round, slightl not fle chief consideraside. The color is very bright, deep rose-carmine scarlet with distinctly white tip. The flesh is white and of the best quality. Pkt. $5 \mathrm{c} ;$ oz., $10 \mathrm{c} ; 2$ oz., $15 \mathrm{c} ; 1 / 4 \mathrm{lb} ., 30 \mathrm{c} ; 1 \mathrm{lb}$., $\$ 1.00$, postpaid.

EARIY SCARIET TURNIP-A round, red, turnip shaped radish with small tops of very quick growth, deserving general cultivation on account of its rich, scarlet-red color, almost crimson, and it white, crisp, tender flesh. The roots often grow one inch long by white, crisp, tender flesh. The roots often grow one inch long by 5c; oz., 10c; 2 oz., $15 c ; 1 / 4$ lb., $30 \mathrm{c} ; 1$ lb., $\$ 1.00$, postpaid.

FRENCF BREATEAST-A quick growing. small, olive-shaped fourths of an inch in diameter when fully grown. The color

rose-scarlet except a little clear white about the tip. Pkt. 5c; oz., 10c; $20 z$ $15 \mathrm{c}$; 1/4 lb., $25 \mathrm{c}$; 1 lb., $75 \mathrm{c}$, postpaid. FAIT IONG DFTP SCARTET-The roots of this desirable early variety are of a deep, rich red color and are olive shaped or half long, with a somewhat tapering point. The tops are comparatively small. The flesh is rery white. crisp and tender, and does not becom pithy as soon as most other early sort Pkt., 5c; oz., 10c; 2 oz., 15c; $1 / 4 \mathrm{lb}$ $25 \mathrm{c} ; 1$ lb., $75 \mathrm{c}$, postpaid.

GTOB-This variety is of quick growth, affording crisp and tender adishes even in a very hot climate and is extensively grown in the South. The roots are uniformly globe-shaped, with skin of golden yellow color. Pkt., $5 \mathrm{c}$ $\$ 1.00$, nostpaid.

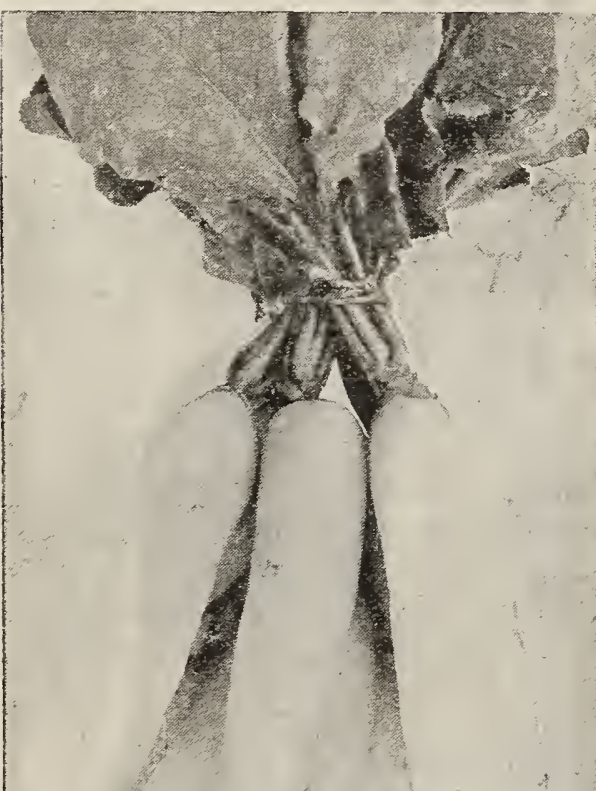
r. five-eights to three-

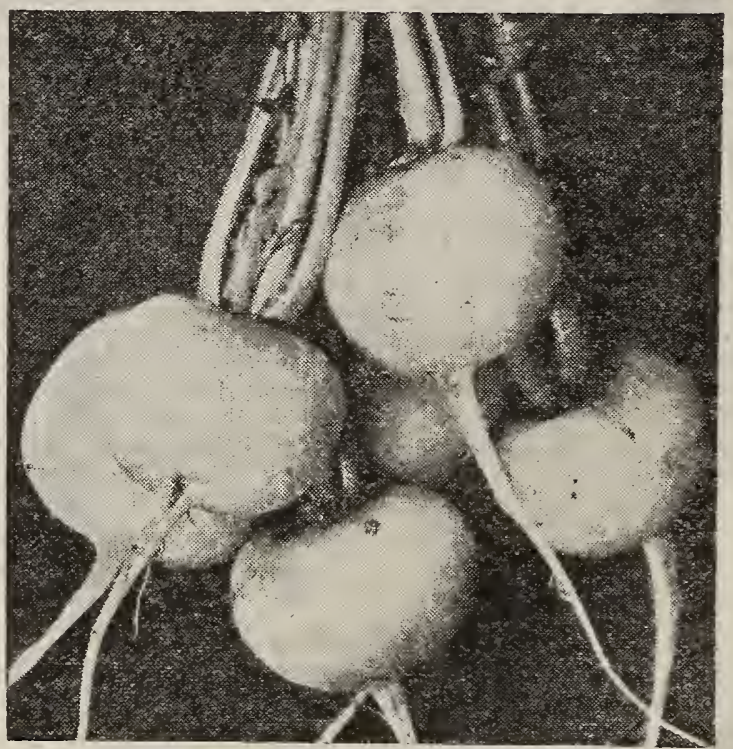

TUCKER'S WFITI TURNIPS

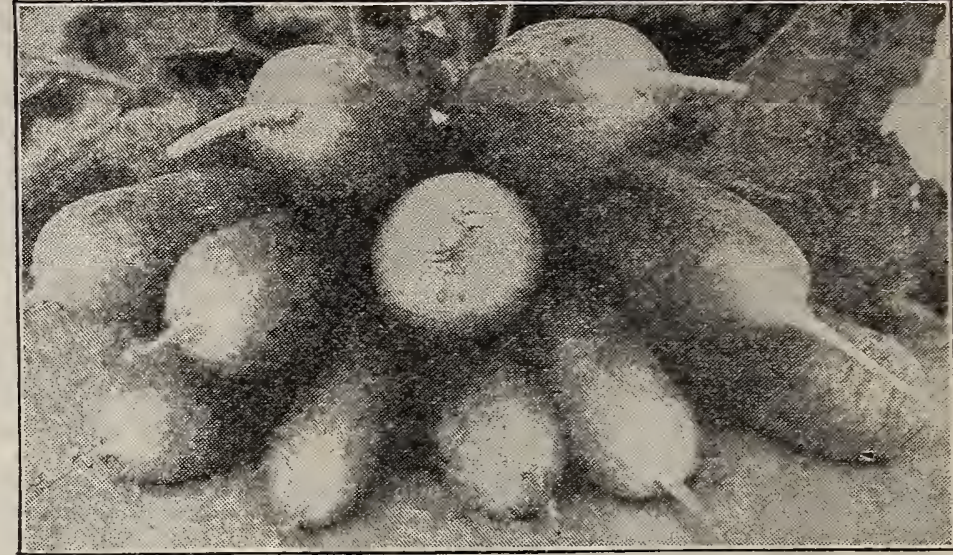

FRENCH BREATEAST

CRIIISON GIANT TURINIP-A roun radish of exceptionally large size for so early a variety. The roots are nearly globe-shaped, of beautiful crimson-carmine color and more excellent quality. often growing one and three-fourths inches in diameter before becoming pithy Plt $5 \mathrm{c} ; 0 \mathrm{z} ., 10 \mathrm{c} ; 2$ oz., $15 \mathrm{c} ; 1 / 4$ lb., $30 \mathrm{c} ; 1 \mathrm{lb}$. $\$ 1.00$, postpaid.

NON PIUS UTTRA OR TARTY DIFP SCARTET TURNIP, FORC ING-This is an excellent extra earl forcing radish. The roots are smali nearly round, and of bright scarlet color. The tops are very small. The flesh is white, crisp and well flavored. One of the Landsomest of the forcing varieties. Plit. sc; oz., 10c; 2 oz., 15c: 1/s lb., $30 \mathrm{c}$ : lb, $\$ 1.00$, postpaid.

IONG BIACK SPANISH-One of the latest and hardiest long garden radishes, especially adapted for winter use. The roots are long, thick, almost black, somefirm texture decidedly pungent but well flavored. Pkt. 5c; oz. $10 \mathrm{c} ; 2$ oz, $15 \mathrm{c}$ $1 / 4$ lb., $25 \mathrm{c} ; 1$ lb., $75 \mathrm{c}$, postpaid.

ROUND BIACK SPANISH-Roots round, sometimes top shaped, three or four inches in , skin black, fesh white; very compact and highly flavored; an excellent sort for winter, roots keep a long time. Pkt., $5 \mathrm{c}$; 0z., 10c; 1/4 1b., 25c; 1 lb., $75 \mathrm{c}$, postpaid.

PUCKER'S ROSE TURIIP RADISH-This variety is distinguished by its color, which is a charming shade of rosy pink. In other respects it closely resembles the better known Scarlet Turnip. It grows very quickly maturing in thirty days. The tops and roots are of medium size, and the flesh is pure white, crisp and of good flavor, Pkt., 5c; oz., 10c; 1/4 1b., 30c; 1 lb., $\$ 1.00$, postpaid.

WHITY STRASBURG-Even when comparatively small this variety is in good condition for When the roots are four to six inches long by $11 / 2$ to two inches in diameter. Pkt., 5c; oz., 10c; 2 oz., 15c; r/4 1b., 25c; 1 lb., $75 \mathrm{c}$, postpaid.

IMPROVFD CHARTIFR OR SHFPHFRD-One of the best long radishes for planting out doors for early summer use in the home garden, and used also for the market. Pkt., 5c; oz. 10c; 2 oz., 15c; 1/ lb., $25 \mathrm{c} ; 1$ lb., $75 \mathrm{c}$, postpaid.

ROSF CFINA WINTrR-Very largely planted for fall and winter use. Half-long in shape and of a bright crimson color. The flesh is white, fine grained and of good quality. Pkt., $5 \mathrm{c}$ oz., $10 \mathrm{c}$; 1/4 lb., $25 \mathrm{c} ; 1 \mathrm{lb} ., 75 \mathrm{c}$, postpaid.

CINCINNATI MARKIT-A desirable market variety with roots similar to Early Lone Scarlet, Short Top, Improved, but averaging longer, deep red in color and remaining a little longer in condition for use. Pkt.. 5c: oz., 10c; 2 oz.. 15c; 1/4 lb., 25c; 1 lb., 75c, postpaid EARIY WHITY TURIIP-This is an early white radish, a little more flattened than Earl. Scarlet Turnip, and as offered by us, of smaller size and sometimes a little earlier maturing. Pkt., 5c; oz., 10c; 2 oz., 15c; 1/4 lb., 25c; 1 lb., 75c: postpaid.

IONG WHITE VIFNNA, OR TADY FINGER-An early maturing and attractive, long, white, summer radish of most excellent quality. Pkt., 10c; oz., 10c; 2 oz., 15c; 1/4 1b., $25 \mathrm{c}$ 1 lb., $75 \mathrm{c}$, postpaid.

ICICII-A very attarctive. pure white radish, the earliest of the long white summer sorts and of most excellent quality. Pkt.. $5 \mathrm{c} ;$ oz., $10 \mathrm{c} ; 2$ oz., 15c; 1/4. 1b., $75 \mathrm{c}$, postpaid.

FARIY IONG SCARITT SHORT TOP, IMPROVED-This is a standard, most excellent sort, either for the home garden or the market. The tops are short and comparatively small. The reots are smooth, slender, uniform in shape and a very attractive bright carmine-red in color. Pkt. 5c; oz., 10c; 2 oz., $15 \mathrm{c} ; 1 / 4$ lb., $25 \mathrm{c} ; 1$ lb., $75 \mathrm{c}$, postpaid.

TIPPID-One of the brightest and handsonest

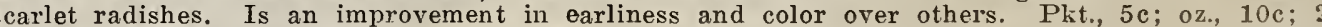
7.. 15c: 1/1 lh.. 25c: 1 lb. $75 \mathrm{c}$, postpaid.

FARIY FRAMr-This is not only a very good variety for forcing but is one of the very best sorts for first crop ont of doors. Pkt., 5c; oz., 10c; 2 oz., 15c; 1/4 1b., 25c: $11 \mathrm{~b} .075 \mathrm{c}$ postpaid. 


\section{BEST IRISH SEED POTATO}

It is a fact that many farmers have to buy their eating Potatoes during many seasons. Not enough attention is given to the seed or manner of planting. Many plant seed that is left over from the stock used during the winter and every one knows when the good wife, or the girls go after potatoes, they pick the large ones, as they are easier to prepare. When spring comes, there is little left except small ones and the culls. Our seed is of the best.

Plant in rows from 27 to 30 inches apart, dropping the potatoes from 10 to 12 inches apart in the row; cover 4 inches deep. Plant as early in the spring as the ground can be had in fair working order. Sandy loam is best suited for potatoes. One peck will plant 125 hills in drill, or eight to ten bushels per acre.

IRISH COBBIFR-It ripens very evenly, every hill seeming to ripen at one time. Its cooking qualities and Havor are first class. One of the favorites in all localities for early and late planting. The tubers are round in shape. Eyes somewhat deep. The skin is pure white and attractive. It is a heavy yielder. There is a demand for Irish Cob$65 \mathrm{c} 1$ bushel from all sections. We have the

BIISS RED IRIUMPH-An extremely hardy and red skin variety which is almost round, covered with eyes and usually deep set in the potato. This variety produces a very small vine and consequently will make a crop with less moisture than any other sort. One peck, $75 \mathrm{c}$ : 1 bushel, $\$ 2.25 ; 2 \frac{1}{2}$ bushel sack, $\$ 5.25$.

EARIY SIX WEEIS-A very early potato especially recommended for early márket and family use. A very large yielding variety smooth skin, slightly blushed, shallow eyes and of good appearance: good quality; cook mealy and $\$ 2.25 ; 2 \frac{1}{2}$ bushel sack, $\$ 5.25$.

FARIY OHIO-A favorite among gardeners everywhere, and particularly well suited to light or loamy larly well suited to light or loamy soil, though it succeeds well anyslightly fiushed with rose, and is of excellent quality. A favorite for early market or family use. 1 peck, $75 \mathrm{c} ; 1$ bushel, $\$ 2.25 ; 21 / 2$ bushel sack, $\$ 5.25$.

IOOKOUT MOUNTAIN PO. TATO-Very prolific, late; long TATO-Very prolific, late; long keeping variety, for planting in white, smooth, of good quality. No white, smooth, of good quality. No
other variety stands our hot climate as well. We book orders now for shipment first of June. 1 peck. $75 \mathrm{c} ; 1$ bushel, $\$ 2.50 ; 21 / 2$ bushel sack, $\$ 6.00$
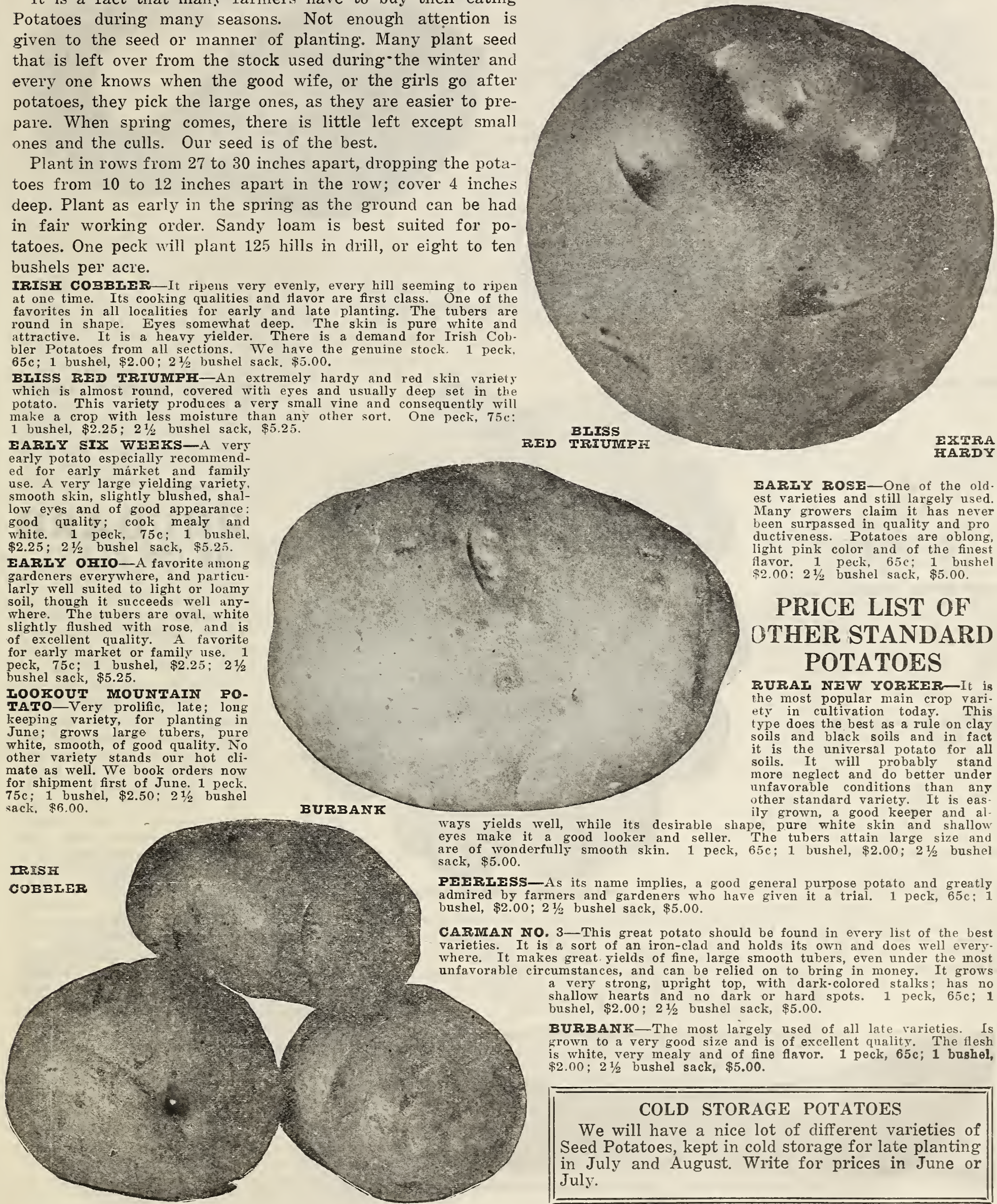
yields well, while its desirable shape grown, a good keeper and al eyes make it a good looker and seller. The tubers attain large size and re of wonderfully smooth skin. 1 peck, 65c; 1 bushel, $\$ 2.00 ; 2 \frac{1}{2}$ bushel PFERIESS-As its name implies, a good general purpose potato and greatly armired by farmers and gardeners who have given it a trial, 1 peck, $65 \mathrm{c}$. 1 shel, $\$ 2.00 ; 2 \frac{1}{2}$ bushel sack, $\$ 5.00$

CNOAN 3-This great potato should be found in erery list of the best varieties. It is a sort of an iron-clad and holds its own and does well every where. It makes great yields of fine, large smooth tubers, even under the most cumstances, and can be relied on to bring in money. It grows
a very strong, upright top, with dark-colored stalks; has no shallow hearts and no dark or hard spots. 1 peck, $65 \mathrm{c} ; 1$ bushel, $\$ 2.00 ; 21 / 2$ bushel sack, $\$ 5.00$

BURBANK-The most largely used of all late varieties. Is grown to a very good size and is of excellent quality. The flesh is white, very mealy and of fine flavor. 1 peck, $65 \mathrm{c} ; 1$ boshel, $\$ 2.00 ; 2 \frac{1}{2}$ bushel sack, $\$ 5.00$.

\section{COLD STORAGE POTATOES}

We will have a nice lot of different varieties of Seed Potatoes, kept in cold storage for late planting in July and August. Write for prices in June or July. 


\section{SQUASHES:}

\section{SUMMER OR BUSH VARIETIES}

Squash will not stand frost and cold nights, hence plantings should not be made until danger of frost and cold nights are over. Ground should have been worked deeply before planting For bush varieties, hills should be 3 to 4 feet apart each way; 6 to 10 seeds in each hill, thinning out to 2 plants when rough leaves have formed. Cover seed about $1 \mathrm{inch}$. One or two shovelfuls of well-rotted manure to each hill, thoroughly orked into the soil is advantageous. Hoe frequently, keeping down all weeds and grass and surface of the soil loose, but do not disturb the plants. As the squash formed picked off as soon as ready for use, as this keeps the plants in bearing longer.

Rumning squash for fall and winter use should not be planted

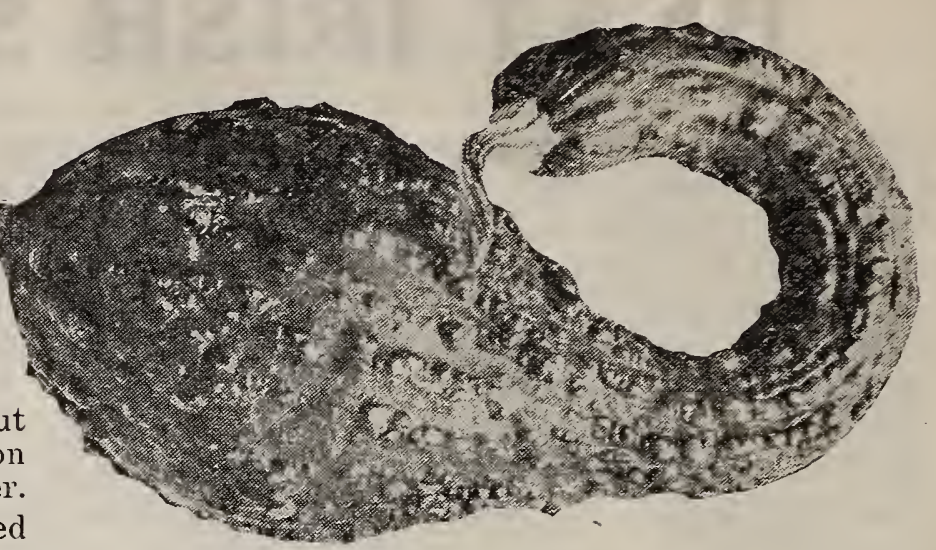
until June or July in this latiude. Hills for these should be made 8 to 10 feet apart. Hoe frequently, but do not disturb the runners. Seed requiled: One ounce to 25 hills; 2 to 3 pounds per acre.

NEW FORDFOOK-Hardy, most dependable, fine for baking. The flesh of this Squash is very dry and sweet. It is one of the earliest of the winter varieties. The outside color is bright rellow; inside color straw rellow. The skin is so thin that it is unnecessary to remove it before cooking. The meat is thick and can be used at any stage of their growth. Pkt., 5c;0\%, 10c; 1/. lb.. 35c; $1 \mathrm{lb}$. $\$ 1.00$, postpaid.

GOIDEN HUBBARD - The vines of this variety are vigorous and very productive. The fruits are of medium size, weighing from six to eight pounds and in shape are like the Hubbard, although in condition for use de. cidedly earlier. The shell is moderately warted, hard, strong and of a beautiful orange-red color, except for a bit of olivegreen on the blossom end. The flesh is deep-orange, dry, fine grained and richly flavored. Pkt. $5 \mathrm{c} ; 1$ oz., $15 \mathrm{c} ; 2$ oz. $25 \mathrm{c} ; 1 / 1 \mathrm{l}$., $35 \mathrm{c} ; 1 \mathrm{lb}$, , $\$ 1.00$, postpaid MAIIMOTE WHITE BUSHA marked improvement over the double the size and more regula. in shape. Early. uniform and prolific, has beautiful clear white skin and flesh and grows 10 to 12 inches in diameter. Pht. $5 \mathrm{c}$; oz. paid.

\section{FARIY WHITE BUSH} Patt known White Scalloped of earliest to mature, rery produc tive; skin and flesh a light cream color. A very popular variety for shipment, being a general favorite for home gardeners everywhere. Pkt., 5c; oz., 15c; 1/4 1b., 35c; 1

BOSTON MARROW-This is a very productive fall and winter variety, of medium to large size, oval shape and thin skin. It is

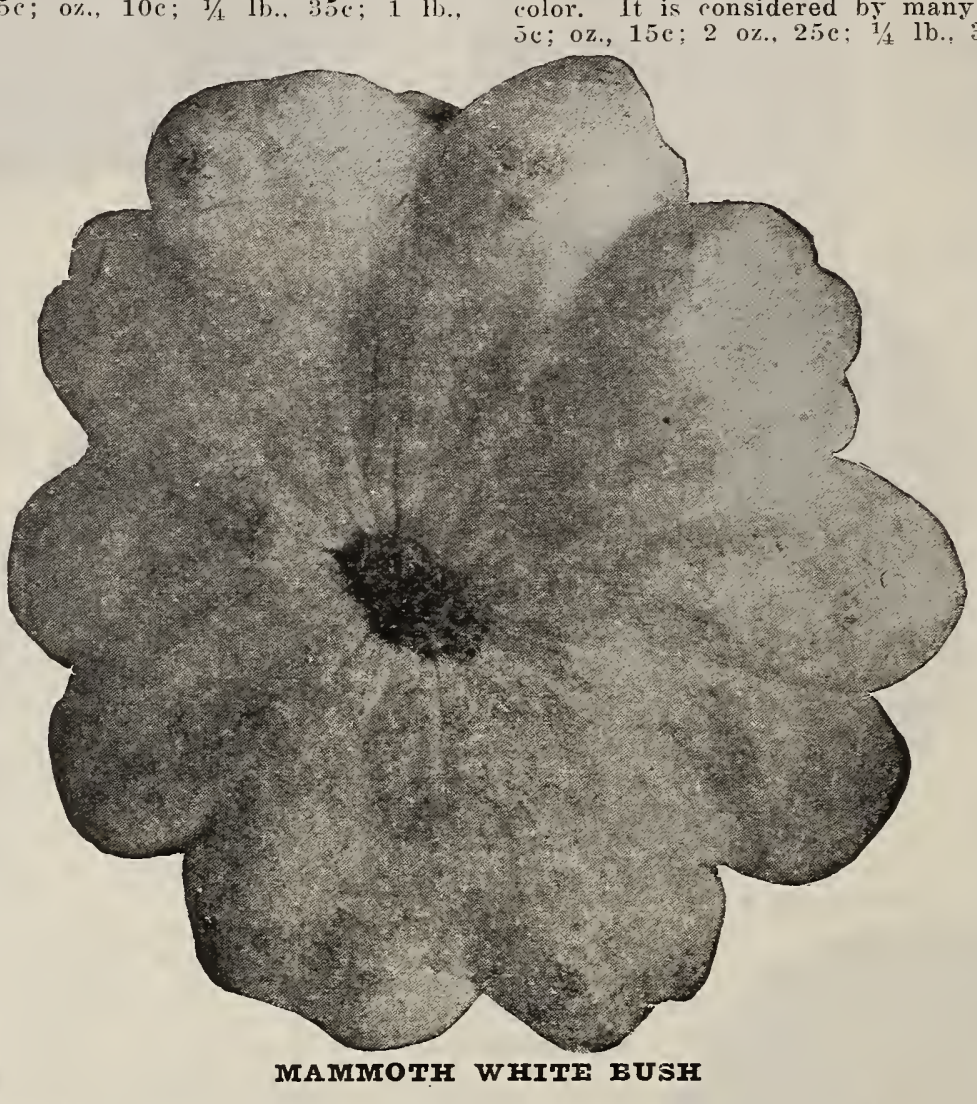

thick, dry lichly flavored. This squash can be kept in good con b., $\$ 1.00$, postpaid.

DEIICrous-Delicious is a fall and winter variety of medium The fruits are moderately hard, usually dark green, but ize. The fruits are moderately hard, usually dark green, but cometimes lighter in color and mottled, and are without any hard shell. The flesh is thick, very fine grained and bright yellow in lor. It is considered br many to be the best for markets.

YEIIOW SUMMIR CROOK. NFCK-One of the best of the ICI-One of the best of the st is of dwarf. The skin is vellow. The flesh has a greenish-yellow color, and is dry and of most agreeable flavor. F'kt. c; oz.. 15c; $1 / 4$ lb., $35 \mathrm{c} ; 1 \mathrm{lb}$. ostpaid.

\section{RHUBARB OR PIE PLANT}

Rhubarb, also known as Pie Plant, or Wine Plant, is the earliest spring vegetable and is grown for its leaf stalks which are extensively used for pies and sauce.

Rhubarb succeeds best in deep, somewhat retentive soil and the richer this is and the deeper it is stirred, the better. Sow in drills an inch deep and thin out the plants to six inches apart. In the fall transplant into very highly manured and deeply stirred soil, setting them four to six feet apart each way and give a dressing of coarse manure every spring. The stalks should not be plucked ing pies. The fruits when ripe are bright orange with a shading of light cream color. The flesh is of rich salmon yellow color, fine Pkt FUBBARD-One of the best of the winter squashes. The rine are vigorous and very productive. The fruits are large, heavy and moderately warted, with a very hard shell. The skin is uniformly dark bronze green. The tlesh is bright orange, vellow, fine grained,

until the second year. When a blossom stalk appears, it should be cut back well into the ground and the plant never be allowed to exhaust itself by rumning to seed. Our seed is saved from selected plants of the Linnaeus, Victoria, Giant and other improved sorts, but like the seeds of fruit ilecs, rhubarb seed cannot be relied upon to reproduce

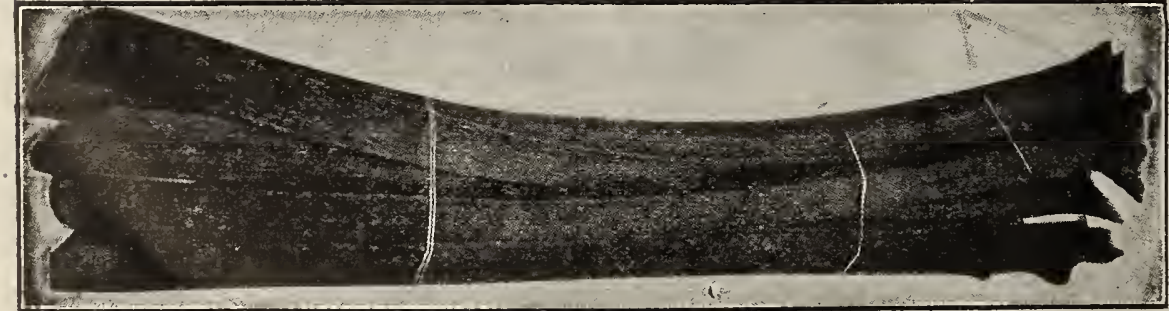

IEUTARB OR PIE PUANT
- The roots may be planted early in the spring or fall, setting the roots from 4 to 5 feet apart cach way. Once planted they will remain in heir bearing condition five or six year's, only lequiring a top dressing of manure in the spring or fall.

SEED-Pkt., 5c: oz., 20c; 2 oz., 35e: 1/2 lb., 50c; 1 ll., $\$ 1.50$, postpaid.

ROOTS-By mail, prepaid. $15 \mathrm{c}$ each; by express not prepaid, $\$ 1.25$ per do\%en. By parcel post. add $2.5 \mathrm{e}$ ner dozen, postage. 
One ounce sows 100 feet of drill; 5 lbs. per acre in drill; 10 to $15 \mathrm{lbs}$. broadcast. One-half pound is sufficient for a medium garden. Sow in February, March or April. For fall and early spring, sow in September or October.

Sow in drills one inch deep, eighteen inches to two feet between the rows, or it can be sown broadcast like kale. Requires but little or no cultivation.

SAVOY IFAVED-This sort is known also as Bloomsdale and as Norfolk Saroy Leaved. It is a very early variety and one of the best to plant in autumn for early spring use. The plant is of upright growth, with thick, glossy, dark dreen loaves of medium size, pointed but quite broad, and crumpled or blistered like those of Savoy Cabbage. It is hardy and grows in wam weather. Seed round. Pkt., 5c; oz.. 10c; $1 / 1 / 1 \mathrm{~b} ., 20 \mathrm{c} ; 1 \mathrm{lb} ., 75 \mathrm{c}$, postpaid. BROAD FIANDERS-An early and vigorous growing round seed variety. The leaves are bright green, broad and thick, with long petiole, usually broad arrow-shaped, but sometimes rounderl. The surface is fairly smooth or sometimes slightly crumpled. It is a most desirable bunching sort for market gardeners. Pkt., $5 \mathrm{c}$ oz., 10c; $1 / 4 \mathrm{lb}, 20 \mathrm{c} ; 1 \mathrm{lb}, 70 \mathrm{c}$; postpaid.

VICTORIA-An excellent variety, forming very large, exceedingl thick, very dark green leaves, slightly crumpled in the center. The plant is large, compact and procumbent. The season is intermediate Pkt., 5c; oz., 10c; 1/t lb., 20c; 1 lb., 70c, postpaid.

IONG STANDING-An improved round seeded strain of excellent quality, comparatively late in season, but after reaching maturit it remains in condition for use much longer than most sorts. Plit.. $5 \mathrm{c}$; oz., 10c; 1/4 lb., 20c; 1 lb., 70c, postpaid.

NEW ZEATAND (TETRAGONIA FXPANSA)-Cinlike true spinach in type and in that it thrives during hot weather and in any

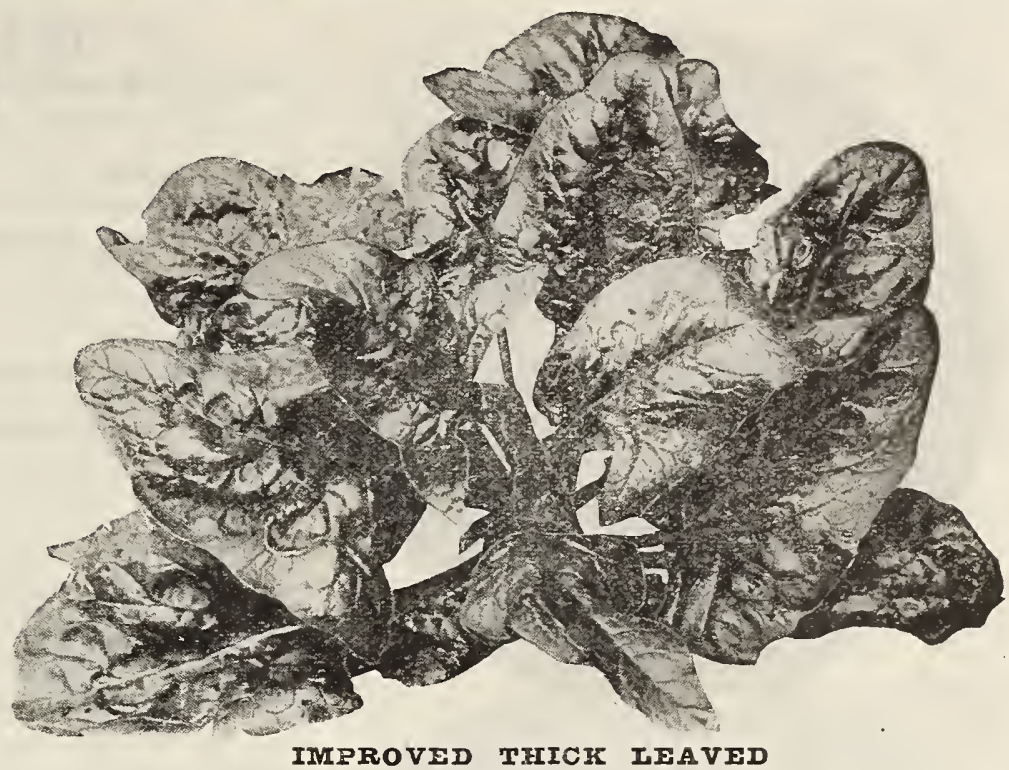

be cut throughout the summer. The plant becones very large and preading. The leares are comparatively small, broad and pointed. Plant three or four seeds in hills, two feet apart each way. Germination of the seed can be hastened by soaking in warm water lb., \$1.00. postpaid.

IMPROVED THICK IEAVED-A variety which grows rapidly forming a cluster of very large, slightly crumpled leaves of dee green color and broad arrow-shaped, but sometimes rounded. Thi is an extensively used medium early sort for the market and hom garden. Seed round. Pkt., se: oz., 10c; 1, 1b., 20c; 1 lb.. 70 c

\section{TUCKMO BRAND TOMATOES}

Sow in hotbeds in the early spring or the seed may be sown in a shallow box, transplant to the open ground after all danger of frost is over, setting the plants three to four feet apart each way. Use well-rotted manure in the hills. Some support should always be provided for the vines to keep the fruit from touching the ground. Tomatoes may be had several weeks earlier if transplanted to small pots; when these are filled with roots shift to a larger size and transplant to open ground, when weather is warm and settled. Ounce of seed will produce two thousand plants; two ounces is enough for an acre. For early crop sow in January.

Tomatoes will train to stock or trellis and the fruit as a rule is much improved. This method of growing tomatoes is very common amongst market gardeners who want fruit for the early market. Place one plant to each stake and tie up with strong soft twine. The plants should be freely pruned as they advance in growth. By so doing the plants receive more air and sum and are certain to thrive better in every way and in addition they can be planted much closer together, insuring a much heavier yield to the acre than if grown in any other way.

Most everyone likes a good Tomato, and acting upon this well known principle, "the best only for our customers,"

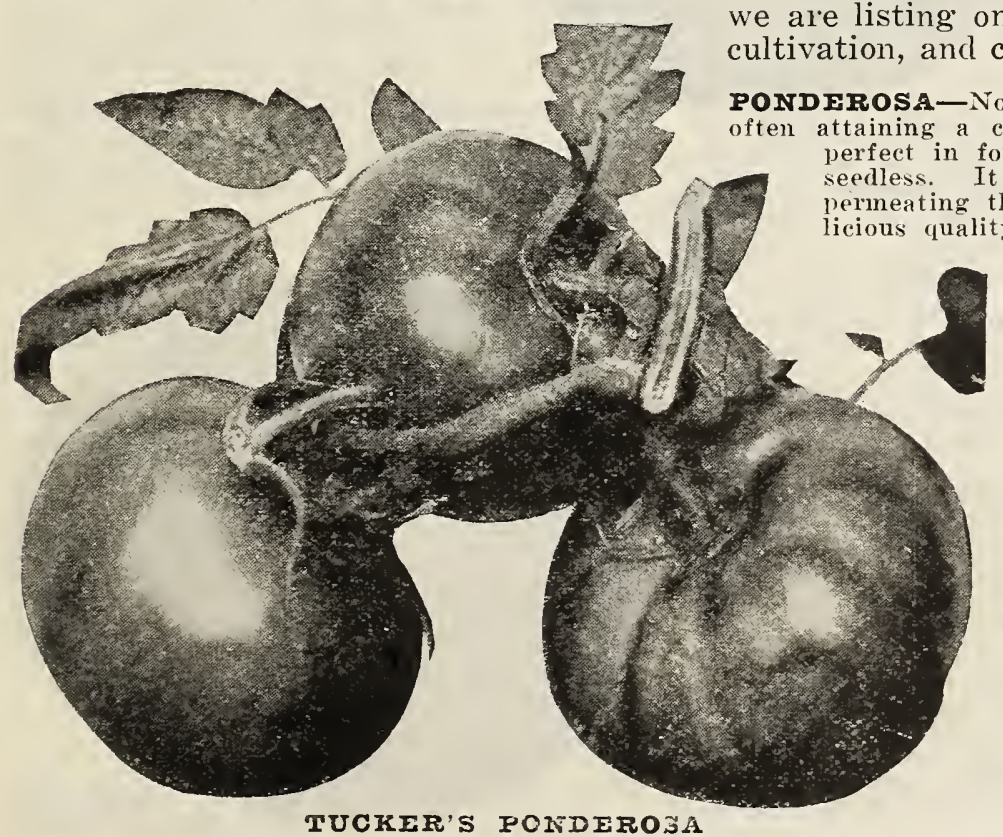
we are listing only those varieties that have proven themselves

TUCKER'S PONDEROJA 


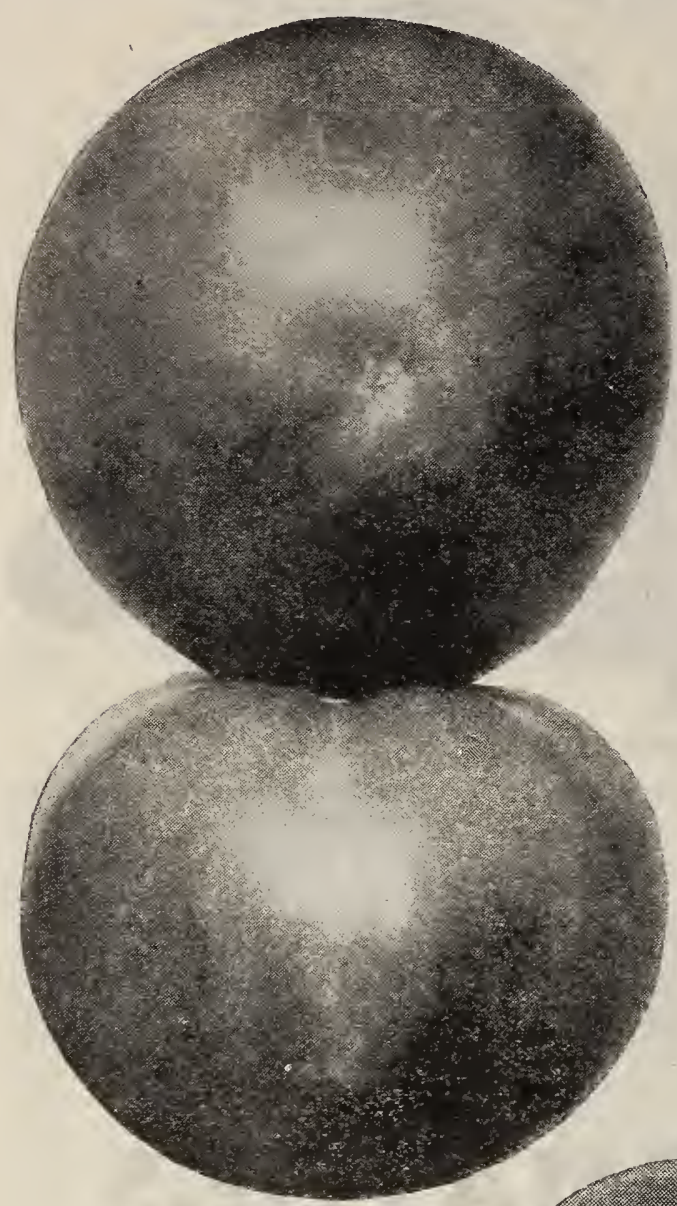

EARIY ACME

CFALK'S EARIY JPWEI Fruits are uniformly larger thicker through, more solid, thicker through, more sold, most of the extra early tomatoes. Pkt., 5e; oz., 25c: 1/1

YFI I OW HUST O R GROUND CHIRRY - This fruit has a pleasant strawberry raw, but generally used for preserves, for which it is excellent. The small yellow fruits are enclosed in a husk or coy ering and when ripe are one half inch in diameter and mas be kept all the winter if th husks are not removed. Pkt. $5 \mathrm{c}$,
oz. $25 \mathrm{c}, 1 / \mathrm{b}$. $85 \mathrm{c}, \mathrm{b}$. $\$ 3.00$

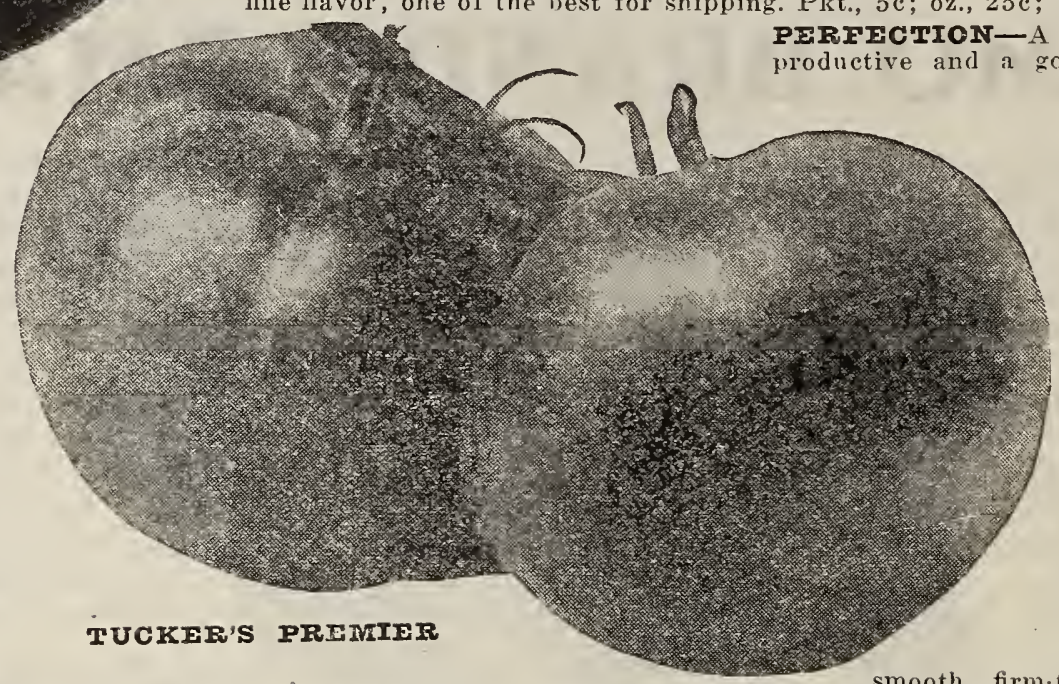
TUCKMO BRAND TOMATOES==-Continued

DWARF CHAMPION-The famous Dwarf Champion Tomato owes its wide popularity to its stiff, vigorous, upright growth, with fruit well above the soil and to the earliness with which it reaches maturity. Pkt., $5 \mathrm{c} ; 0 \mathrm{z}, 25 \mathrm{c} ; \mathrm{I} / \mathrm{l} \mathrm{lb} ., 85 \mathrm{c} ; 1 \mathrm{lb}$., $\$ 3.00$, postpaid. BEFESTEAK-Color bright crimson, solid meat. The tomatoes often weigh two to three pounds each. Pkt., $5 \mathrm{c} ; 0 \mathrm{z} ., 25 \mathrm{c} ; 1 / 2 \mathrm{lb} ., \$ 1.25 ; 1 \mathrm{lb} ., \$ 4.00$, postpaid.

MATCFIESS TOMATO-This variety is well named, for up to the present time it has no equal as a large, second-early, for home use. Vigorous grower, very meaty and solid, with few seeds. Its color is brilliant shade of red and one of the most beautiful tomatoes we have ever seen. Pkt., 5c; $1 / 2$ oz., $15 \mathrm{c} ; 0 \mathrm{z} ., 25 \mathrm{c}$ : $1 / 4 \mathrm{lb} ., 60 \mathrm{c} ; 1 \mathrm{lh}$. $\$ 2.00$, postpaid.

YELIOW PEAR-SHAPED-A popular sort for preserving and pickling; very prolific Pkt., 5c; oz., 25c; $1 / 1$ lb., $\$ 1.25$; 1 lb., $\$ 4.00$, postpaid.

CRIMISON CUSHION-One of the best large sorts of bright red color. It ripens evenly, smooth in size, uniform shape and of excellent quality. Pkt., 5c; 0z., 25c; $1 / 4$ lb., $\$ 1.25 ; 1 \mathrm{lb} ., \$ 4.00$, postpaid.

FARIIANA-This is the earliest smooth, bright red Tomato of good size now in cultivation-nearly equal in size and quality to the best later kinds. The plants are quite hardy, with rather slender open branches that are of moderate growth. and well set with fruits, nearly all of which ripen very early in the season. Pkt., 5c; oz., 25c: $1 / 1$ lb., $65 \mathrm{c} ; 1 \mathrm{lb}$., $\$ 2.50$, postpaid.

IIVINGSTON BEAUTY-One of the finest tomatoes for general purposes, whether for garden or market. The color is purplish red; very solid, does not crack easils, grows to be a large size and is very productive. It is medium early. The early fruits are borne in clusters, very smooth and of excellent flavor; good keeper; fine for shipping. Pkt., $5 \mathrm{c}$; oz., $25 \mathrm{c}$; $1 / 1 \mathrm{lb}$., $75 \mathrm{c} ; 1 \mathrm{lb}$., $\$ 2.75$, postpaid.

EARIY ACMRE-This particular variety is well known to be one of the earliest as well as the most prolific sort grown. The fruit is of a good size, almost round, and of flavor. A popular variety for truckers and market gardeners. Pkt., 5c; 0z., 25c; 1/t lb., $65 \mathrm{c} ; 1 \mathrm{lb} ., \$ 2.50$, postpaid.

NEW COREIESS-Livingston's New Coreless is a large, main-crop, globe-shaped, bright red variety, which will be a strong competitor with all old varieties. In shape it is almost round, being about the same diameter each way. Ripens all over and through and righ up under the stem all at the same time. Pkt., 5c; $1 / 2$ oz., 20c; 0z., 30c; $1 / 41 \mathrm{~b} ., \$ 1.25$ $1 \mathrm{lb}, \$ 4.00$, postpaid.

ESSIX HYBRID-Very similar to the Acme fruit, dark purple, always smooth and handsome. Pkt., $5 \mathrm{c}$; oz., $25 \mathrm{c}$; $1 / 1 \mathrm{lb} ., 65 \mathrm{c} ; 1 \mathrm{lb} ., \$ 2.50$, postpaid.

TUCKRR'S EAVORITE-A large and handsome variety; fruits purple, thick meated fine flavor; one of the lest for shipping. Pkt., $5 \mathrm{c}$; oz., $25 \mathrm{c} ; 1 / 41 \mathrm{~b} ., 65 \mathrm{c} ; 1 \mathrm{lb}$., $\$ 2.50$, postpaid.

EARIY DETROIT-The latest new Tomato. The vine is a better yielder and more vig. orous than that of Acme. Not only are more fruits produced, but they average more nearly globe-shaped, are heavier and are equally as firm, smooth, and suitable for shipping. The fruits are of good size throught the season, which is unusually long for so early a variety. Pkt., 5c; oz.. 25c; $1 / 4$ lb., $75 \mathrm{c} ; 1$ lb., $\$ 2.75$, postpaid.

DWARF STONE-A dwarf, upright-growing variety, bearing a large yield of splendid fruit similar in shape, color and appearance to the regular Stone. It makes a strong upright habit of growth and holds the fruit up off the gronnd. Pkt.. 5c: $0 z_{2}, 25 \mathrm{c}$ - 1 $1 \mathrm{~b} ., 85 \mathrm{c}$ : $1 \mathrm{lb}$., $\$ 3.00$, postpaid.

NEW STONE-A most valuable main-crop variety, and deservedly one of the most popular Tomatoes in our list for shipping, canning and the home market. Of large size, bright scarlet color, and withstands rot and blight better than any other sort. Pkt., $5 \mathrm{r}$ : $0 \mathrm{z} ., 25 \mathrm{c} ; 1 / 4 \mathrm{lb} ., 50 \mathrm{c} ; 1 \mathrm{lb} ., \$ 1.60$, postpaid.

BONNY BEST-The fruits of this desirable early sort are most attractive in shape and color. The crop ripens more uniformly than any other early scarlet fruited sort, and is of superior solidity and interior color. The vines are vigorous and produce a good crop of exceptionally round and deep fruits, bright deep scarlet in color and of very good quality. One of the best for gardeners whose trade demands fruits of beautiful shape And color. A very good variety for the ea.

JOHN BAER-An extra early scarlet fruited variety of superior merit. The vines are very hardy and exceptionally productive. The fruits are the largest of the extra early sorts and are also most attractive in color. They are nearly round, smooth, firm and of excellent quality. It is one of the very earliest to ripen its first fruits and $i$ continues to furnish marketable fruits much longer than other very early varieties. It is an invaluable sort for market. gardeners, shippers and canners. Pkt., 5c; 0z., 25c; 2 oz. $45 \mathrm{c} ; \mathrm{I} / 4 \mathrm{~h}$. $75 \mathrm{c}: 1 \mathrm{ll}$.. $\$ 2.75$ dearer. Pkt.. 5c; oz., 25c $1 / 4 \mathrm{lb}, 65 \mathrm{c} ; 1 \mathrm{ib}$., $\$ 2.50$, postpaid.

TUCRER'S PREMIER - A sturdy and healthy grower; it ripens its first fruits immediately following those of the early sorts, and from that time until frost, it is practically everbearing, yielding enormous. $10 \mathrm{c} ;$ oz.. $35 \mathrm{c} ; \mathrm{s} / 4 \mathrm{lb} ., \quad \$ 1.25$ $1 \mathrm{lb}$., $\$ 4.00$, postpaid.

IIVINGSTON'S GIO B E TOMATO-In shape it is distinct from all others, being a beautiful globe, with quite a good percentage of elongated (stem to blossom) fruits. It is among the first to ripen. Fruit of large size, and good niarketable size is maintained throughout the season; always smooth, firm-Heshed, and has very few seeds. Ripens evenly through and through; a fine glossy red in color, tinged with purple. The plant is always loaded with fruit. Pkt. $10 \mathrm{c}$
0 z., $25 \mathrm{c} ; 2$ oz. $45 \mathrm{c} ; 1 / 1$ lb. $85 \mathrm{c} ; 1 \mathrm{~b} . \$ 3$, ppd.

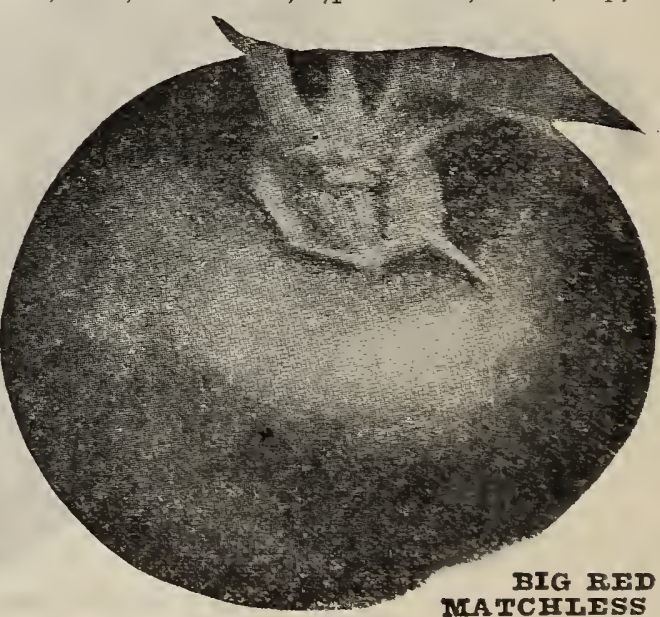




\section{SELECT TURNIPS}

One ounce will sow 400 feet of drill or 360 square feet $(19 \times 19)$. An acre requires $1 \frac{1}{2}$ pounds in drill, 2 pounds broadcast. For spring use sow in February or March. For fall or winter, from July to September. For feeding stock alone, the use of Turnips should be increased ten times as much as at present.

COW HORN OR IONG WHITE-This variety is clear white, except a little shade of green at the top of the root, which is long and carrot-like in $5 \mathrm{e}$; oz., 10c; 1/4 lb., 20c; 1 lb., $75 \mathrm{c}$; postpaid.

EXTRA EARIY PURPIE TOP MIIAN-Of handsome appearance; somewhat flattened, white with purple top. Two weeks earlier than Purple Top, Strap Leaf, good for spring or fall planting. Bulb forms very rapidly. Pkt. $5 \mathrm{c} ;$ oz., $15 \mathrm{c} ; 1 / 1$ lb., 50c; 1 lb., $\$ 1.00$; postpaid.

TUCKER'S FOURTEFN TOP-Very much superior to the Seven Top and Southern Prize. It is grown entirely for its tops, which are used as a

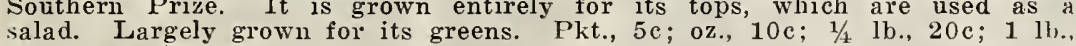
salad. Lostpaid.

TUCIER'S DIXIE IAND-Cultivated in the South for both turnips and greens. i'he tops furnish an abundance of cuttings, while the turnips are used for both table and stock. Pkt., 5e: oz., 10c; 1/4 lb., 20c; 1 lb., $50 \mathrm{c}$, postpaid.

EARIY WHITE FIAT DUTCH-One of the most popular varieties for either spring or fall plantings. Medium size and a quick grower. Plit., $5 \mathrm{c} ; 0 \mathrm{z} ., 10 \mathrm{c} ; 1 / 1 \mathrm{lb} ., 20 \mathrm{c} ; 1 \mathrm{lb} ., 75 \mathrm{c}$, postpaid.

IARGE WHITE NORFOIK-Usually grown for feeding stock, and although a little coarse in

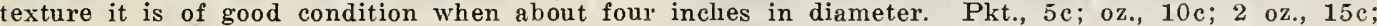
$1 / 1$ lb., 25c; 1 lb., $75 \mathrm{c}$; postpaid.

WHITE EGG-An early oval or egg-shaped variety with smooth, clear white roots of mediun size, which grow half out of the ground. The tops are small with leaves distinctly out of the ground Pkt., 5c; oz., 10c; 1/4 1b., $25 \mathrm{c} ; 1$ lb., $75 \mathrm{c}$, postpaid.

PURPIE TOP WRITE GIOBE-A fine table tumip. It is an early and beavy cropper, as well as a good keeper. The bulb is a very landsome globe, and is especially in emand among market gardeners. This is also a good turnip for stock feed. as it will grow to a large size if left for that purpose. Plkt., 5c; oz.,

EXTRA EARIY WHITE MIIAN - Variety remarkably early. Tops very very small, strap leaved, upright an compe together. Pkt., 5c; oz., 10c; 1/4

lb., 30c; 1 lb., $\$ 1.00$, postpaid.

SOUMHERN PRIZI-Superior to Sevel Tops as usually sold and extensively grown in the South, where the tops furnish an abundance of cuttings. Pkt., $5 \mathrm{c} ; 0 \mathrm{z} ., 10 \mathrm{c}$ 2 oz., 15c; 1/4 lb., 25c-; 1 lb., 60c, postpaid. AMBER GIOBE-Also known as Yellow Stone. By far the most handsome of the yellow varieties. Grows to large size and keeps splendidly well into spring. Pkt. $5 \mathrm{c} ;$ 0z., 10c; $1 / 1$ lb., 25c; 1 lb., 75c: postpaid.

SEVEN TOP 'SAIAD TURNIP' Most popular variety for winter and earl spring "greens" in the South. Very hardy, growing through the severest win ter weather. Pkt., 5c; oz., 10c; $1 / 4 \mathrm{lb}$. $15 \mathrm{c} ; 1 \mathrm{lb} ., 50 \mathrm{c}$, postpaid

PURPIE TOP STRAP IEAF-Prob ably more extensively planted than any
other variety. It is a very early fiat turnip of medium size, the lower portion white and the upper part reddish purple. Pkt., $5 \mathrm{c} ; 0 \% ., 10 \mathrm{c}$; 1/4 lb., 20c; 1 lb., $75 \mathrm{c}$, post paid.
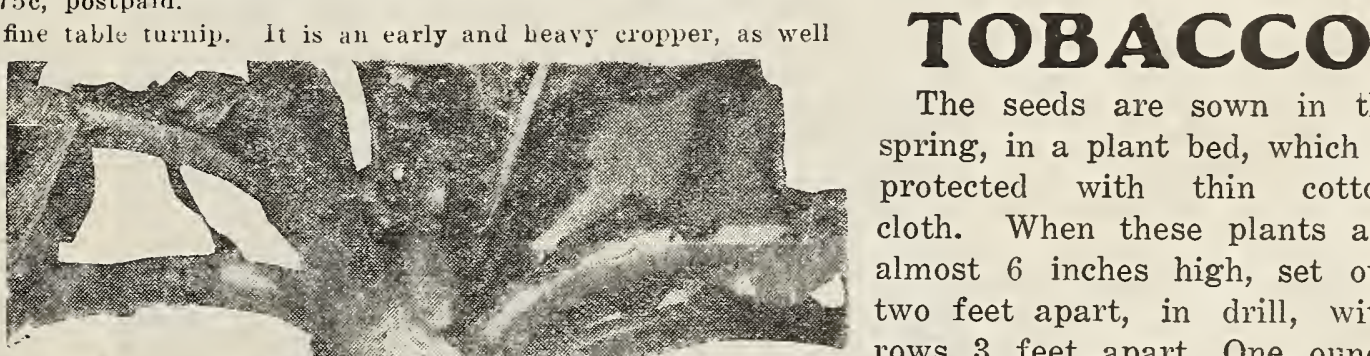

The seeds are sown in the spring, in a plant bed, which is protected with thin cotton cloth. When these plants are almost 6 inches high, set out two feet apart, in drill, with rows 3 feet apart. One ounce of seed will make plants to set out three acres.

YEIIOW GIOBE-n round, smootll, light yellow turnip of medium size. The flesh is crisp, firm and of very good quality for the table or for stock feeding. The roots are in best condition for table use when three to four inches in diameter. This sort keeps well and is a good cropper. Pkt, $5 \mathrm{c}$; 0 . $10 \mathrm{c} ; 1 / 1 \mathrm{lb}, 20 \mathrm{c} ; 1$ lb., $75 \mathrm{c}$, postpaid.

PURPIE TOP YMIIOW ABERDFEN-Medium sized The roots are yellow with purple top. The flesh is pale yellow in color. Pkt., 5c; oz., 10c; 1/4 lb., $20 \mathrm{c} ; 1$ lb., $75 \mathrm{c}$, postpaid. POMERANIAN WHITE GIOBE-One of the most productiv kinds and in good, rich soil roots will frequently to twelvpounds in weight. It is globe shaped or slightly flattened; skin very white and smooth. Pkt., 5c;0z.. 10c; $5 / 41 \mathrm{~b} ., 20 \mathrm{c}: 1 \mathrm{lb}$. $75 \mathrm{c}$, postpaid.

\section{RUTABAGAS}

SWIDISH AND RUSSIAN TURNIPS

Sow either broadcast or in drills 2 feet apart, thinning out to six inches and roll the ground after sowing. Rutabagas should be sown in July and early in August and earthed up as they grow. The salad turnips require three pounds per acre.

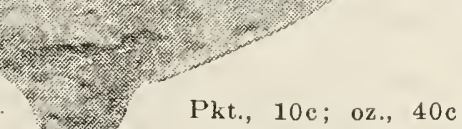

lb., $\$ 1.25$.

CONNECTICUT SEED IEAF-A quick maturing, stock sort, leaves moderate length and of good width. Good for fillers. Pkt., 10c; oz., 25c; 1/4 lb., 75c; 1 lb., $\$ 2.50$.

\section{SELECT VARIETIES}

fillers and smoking tobacco. On rich lands yields a heavy crop.

IMPROVID YEILOW ORONKO-Fine yellow wrappers

splendid for cutters or smoking.

KENTUCKY YRIIOW-A fine broad-leaf, suitable for strips, dark wrappers as well as briglit grades. Best suited to gray or sandy soils. BROAD IEAF GOOCH-A good variety for heavy mahogany wrappers as well as bright grades. Best suited on gray or sandy soils.

BIG ORONOKO-Broad, long leaf, of fine texture dark color, good fillers and strips of sun-cured tobacco.

PRICES SUBJECT TO CRANGE WITHOUT NOTICE 


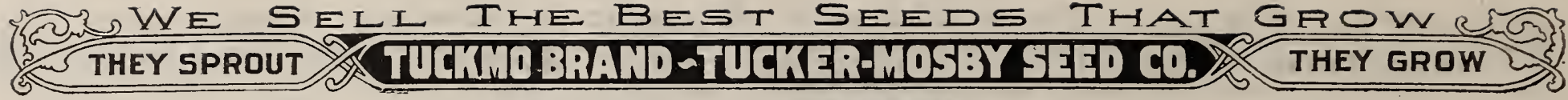

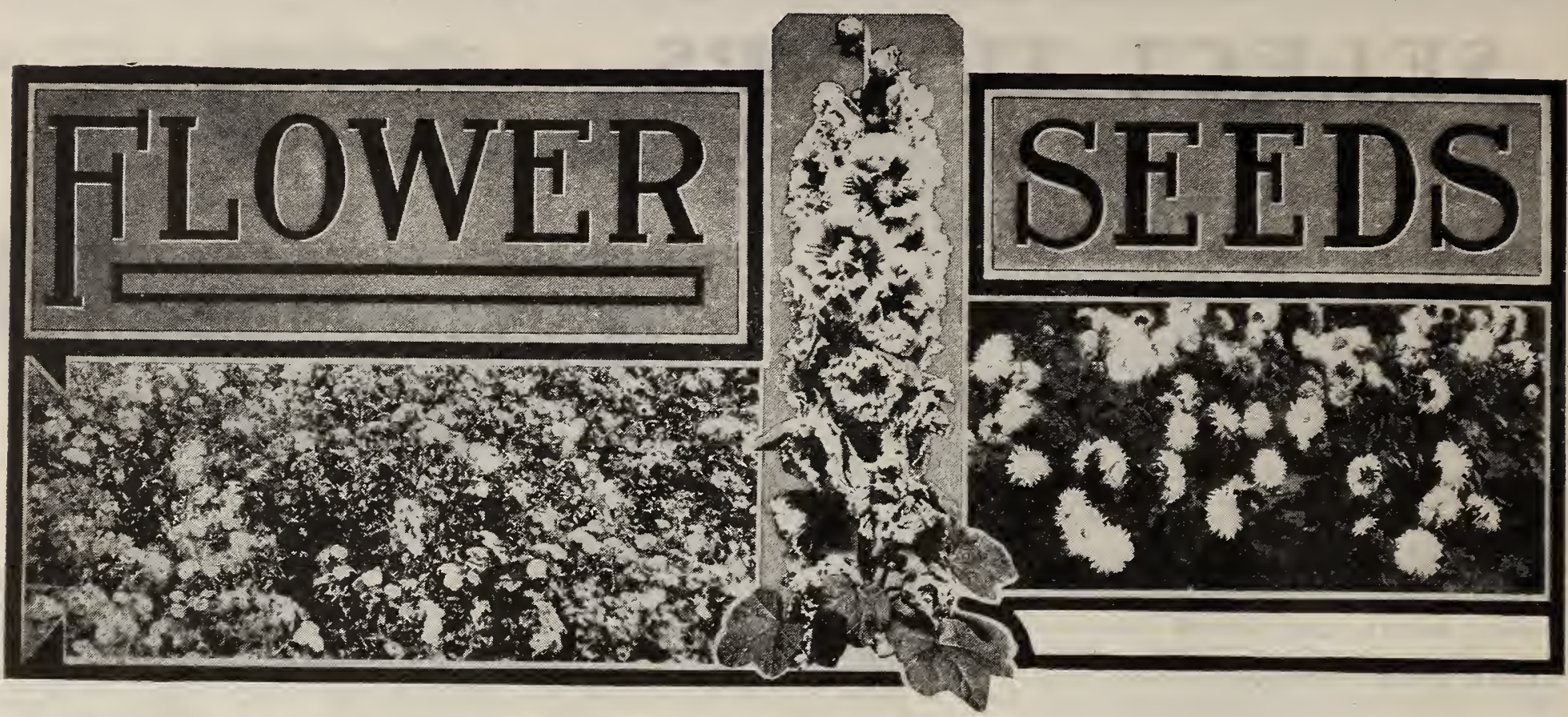

A DESCRIPrIVE IIST OF CHOICE FIOWER SEEDS. Most flowering plants will live in almost any soil, but to give then a fair chance to develop, some care should be taken to make the ground suited to their needs. The soil best adapted for flowering amount of sand to render it porous. Many flowers are better if produced on plants of rigorous growth, hence a portion of the garden should be prepared by deep digging, thorough pulverization and liberal enriching with lage quantities of well-rotted manure. Since eral enriching with large quantities of well-rotted manure. Since when grown on rather light, poor soil, a portion of the garden should not be enriched.

Cultural directions are given on the packets, and we urge purchasers to study them carefully.

Plants are usually divided into three classes, Annuals, Biennials, and Perennials. Annuals are plants which normally live but a single season. Biennials are plants living two years; particularly those which do not bear flowers and fruit

SEFDS FOR SPFCIAI PURPOSFS

igned to assist in making selections of suitable varietie.

For Beds and Borders-Ageratum, Antirrhinum. Asters, Calendula. thus, Eschscholtzia, Marigold. Nasturtiums, Pansy. Petunia, Phlox, Dwarf; Poppy, Salpiglossis, Salvia, Stock, Verbena, Zinnia.

For Edgings to Beds and Walks-Ageratum, Dwarf; Alrssum, Dwarf; Aster, Dwarf; Bellis, Candytuft, Dwarf; Cockscomb, Jwarf: Echevaria, Lobelia, Marigold, Dwarf; Myosotis, Nasturtium, Dwarf: Pennisetum, Phlox, Dwarf; Portulaca, Prothrum aurem, Zinnia. Dennis

Fragrant Flowers for Bouquets-Abronia. Alyssum. Asperula, Candytuft, Carnation, Heliotrope, Lavender, Lemon Verbena. Mignonette, Nasturtium, Dwarf; Nicotania, Pinks, Stocks, Sweet Peas. Sweet Rocket, Sweet Sultan, Wallflower.

For Partially Shaded Locations:-Aquilegia, Auricula, Begonia Tuberous, Canterbury Bells, Matricaria, Myosotis, Pansy, Violet. For Boxes and Baskets-Alyssum, Asparagus Sprengeri, Lobelia, Inaria, Mraund Nasturtium Petunia, Smilax rorenia, Climbing Vines-Adilumia, Canary Vine, Cobea, Cypress Vine. Dolichos, Japanese Hop, Kudzu Vine, Moon Flower, Morning Glory, Nasturtium, Tall; Scarlet Runner, Sweet Peas, Thunbergia, Tild Cucumber.

For Backgrounds and Centers- Abutilon, Adonis, Antirrhinum. Aster, Balsam, Camna, Castor Bean, Cosmos, Datura, Digitalis, Delphinium, Euphorbia, Hollyhock, Helianthus, Lupins, Marigold, Marrel of Peru, Nicotania. Pentstemon. Perilla, Salvia. Scabiosa, Sweet Vel of $\mathrm{P}$

\section{ASTERS}

icties, as by this methor of culture the blooning season can be made to extend from Jume until late in the autumn. For best results Asters slould have good rich soil and plenty of moisture. The seed may be sown indoor early and plants set out in May, yet seesls sown in the open groun produce excellent results. The location of the bed should be changer every year. As the roots are produced near the surface, a mulch of some kind spread over them in hot water is very belleficial. Any
extra care is repaid by finer plants, large blooms, stronger stems, and more profuse blooning.

SEMIPIE'S BRANCHING double blossoms of fine form. The plants are distinctly branchiug in habit of growth and are about two feet high.

WHITE-Pure white, very attractive. Packet, 10c.

IMARY SFMPIE-Flesh pink. A very light and charming shade.

IIGFI PINK-A beautiful light pink, tinged with rose. Pkt., 10 TYRIAN ROSE-Flowers are rery attractive. deep purplish rose.

IAVזNDER-Bright lavender; very large flowers of fine form. $10 c$ IIGIST BIUE-Flowers light bright blue; rery large and attrac

CrImson-Flowers bright deep crimson, tinged wití carmine. 10c. PURPIE-Flowers are very deep purplish blue; rich and pleas

SFMPIE'S MIXED-A superb mixture of all the shades and colors found in the Semple's class of late branching asters. Pkt., 10c. ASTERS, FINEST MIXED-A mixture of very fine strains and olors. The bed can he made more attractive by pulling up the
MIKADO PINK (ROCHESTER)-A beautiful mid-season aster of very large si\%e and fine form at first white but changing gradually to light rose or rose with lavender tint. Pkt., 1.s.

VIOLFT KING-Similar in habit to the late branching asters but producing a little earlier very large double blossoms. Color a soft shade of violet. Pkt.. $10 \mathrm{c}$

CRIMSON KING-The flowers are a most attractive rich crimson. are very double in form and they last an exceptionally long time TRUFFAUT'S PERFECTION PEONY FIOWERED-The plants of this mid-season class are of upright growth and are about two feet high. Pkt., 10c.

MIXED-Many shades and colors, rangine from white to deep ro-e and dark rose Pkt., 10c.

DAYBREAK-A very desirable pink, medium early variety. 10c. PURITY-Similar to Daybreak, but pure white. Pkt., $10 \mathrm{c}$.

COMET (SEMI-DWARF)-This mid-season class of semi-dwalf Comet Asters is fully two weeks earlier in blooming than the older Comet strains.

IIGHT BIUT-Pli, $10 \%$ IIIAC-Pkt, $10 \mathrm{c}$

MIXFD-Includes the four above rarieties mixed. Pkt., 10c. CREGO GIANT RINK-A beautiful soft shell-pink flower of largest size. Pkt., 10c.

CRFGO GIANT WHITE-Similar to Crego Giant Pink, but the Howers are glistening pure white. Pkt., $10 \mathrm{c}$.

GIANT COMET-In this class of asters the petals are very long and recurved and twisted near the center. Plants branching about two feet high, more vigorous and taller growing than the ordinar Comet; flowers larger and equal in form. Knorn as Ostrich Plume. White, pkt., 10c; mixed, plit., $10 \mathrm{c}$. 
ISTERS-(Continued)

VICTORIA ASTrRS-Magnificent Howers, double clear to the center; massive and howy, with regular overlapping petals. The flowers measure $t$ to $\overline{5}$ inches across, and the colors include many extremely delicate and some gorgeous shades. The plants are about 18 inches high, and carry from 25 to 40 flowers on a plant. Pure white. Pkt.. Blossom Pink, Pkt., 10c; Finest Mixed, Pkt., 10c

\section{ABRONIA}

A very pretty, half hasdr annual, producing white and rose colored double daist-like flowers. Plit, 10c.

\section{ABUTILON (Flowering Maple)}

Jixed Shrubby plaits suitable for house greenhouse or garden; f-feet. Drooping. bell-shaped flowers of various colors. Pkt., 10c.

\section{ACROCLINIUM (Everlasting)}

A rery pretty, half laardy anmual, producing white and rose colored double daisy like flowers, about one and one-half inches in dianeter. "These are "Immortelles" so desirable for wreaths and winter bouquets.

Sow the seed in open ground early in spring, preferably in light. well prepared soil, and cover with one-fourth inch of fine soil firmly pressed down. Thin the young plants to four inches apart. Height, 15 inches.

ALBUM-Pure white. Plot. $10 \mathrm{c}$. MIXED-Pht., $10 \mathrm{c}$

ROSEUM-Light rose. Pkt, 10 c.

ADONIS (Pheasant's Eye) Beautifully mixed. Pkt., 10c. ADLUMIA (Mountain Fringe)

A graceful hardy biennial climber, but as it reso sidered perennial. The feathery foliage closely resenbles that of the Maiden Hair Fern. The
lower's are tube-shaped, flesh-colored. somewhat like the Bleeding Heart. Pkt., 10c.

\section{AGERATUM}

Profuse blooming plants, bearing clusters of feathers flowers the whole summer. Excellent for cut flowers and fine for large beds in summer and pot plants for winter. Height, 2 ieet. Plit., $10 \mathrm{c}$

\section{A.IARANTHUS}

Fine ornamental plant, many are grown ex clusively for their handsome foliage, also hav beautiful clusters of brilliant colored flowers. which are verr effective for autumn decoration. Plit., 10c.

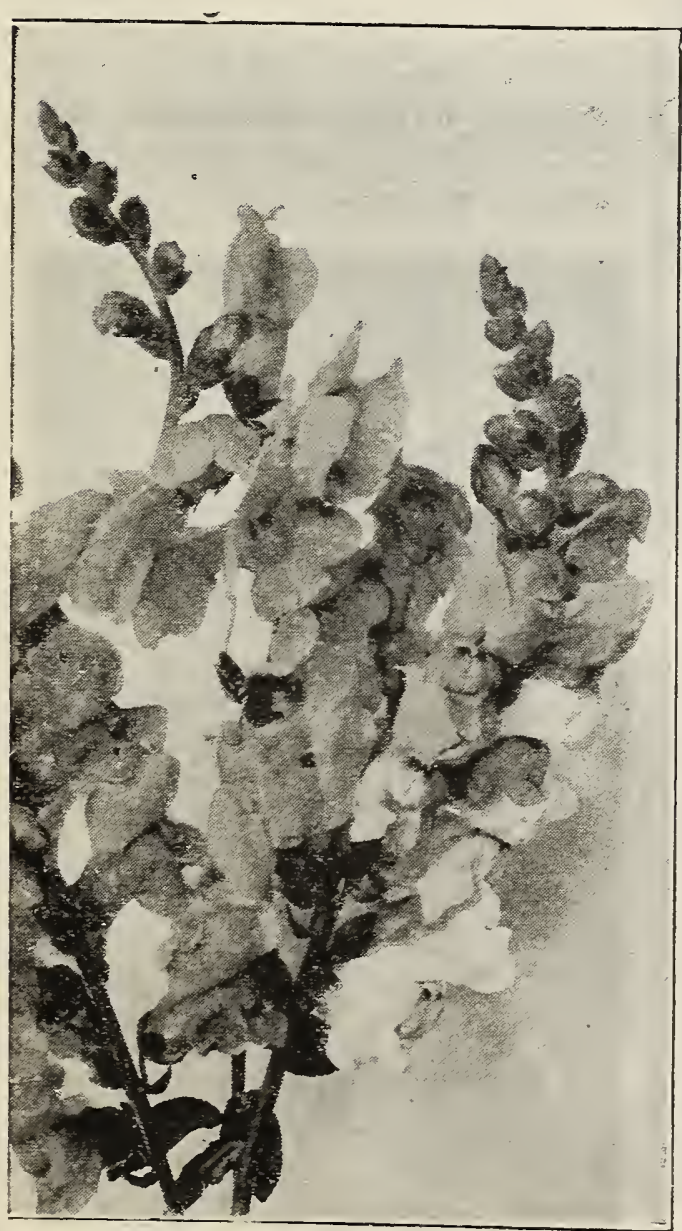

ANTIRRHINUM OR SNAPDRAGON for bouquets. Mixed. Pkt., 10c olors. Mixed. Pht., $10 \mathrm{c}$ Packet, 5c

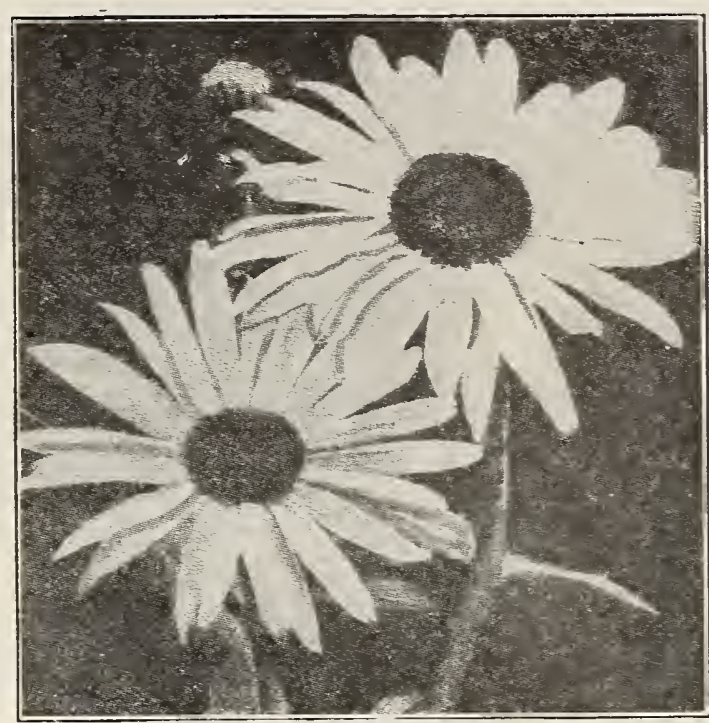

FARDY MARGUGRITI

ALYSSU M

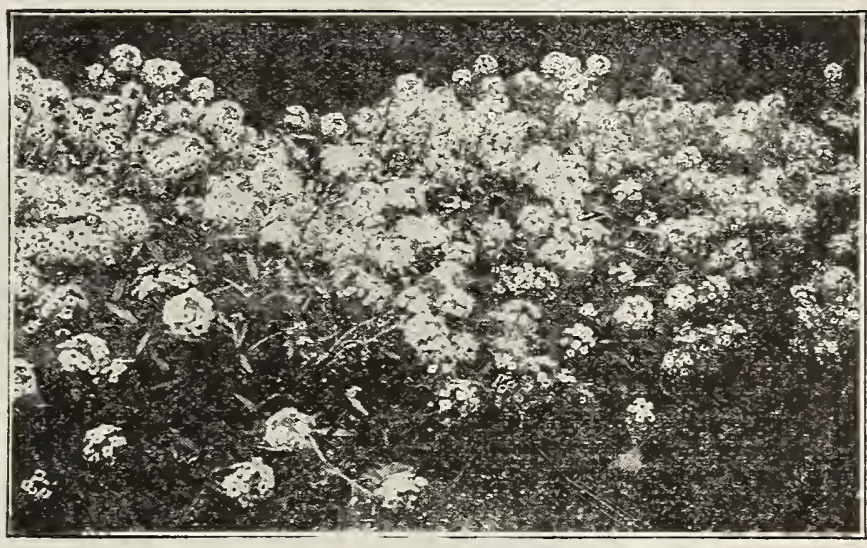

Popular little plants for edging or massing, bloomIVill also do well ill the house in winter.

SWFFT (MARITIMUM) -This very hardy annua comes into bloom very early. in the spring, covering it self with innumerable clusters of small, pure white culiar delicate fragrance, and are useful in all kind. of sinall bouquets. Not ove eight inches high, bu sperads orer considerable ATSSUM (I I T T I I GFIM) - A beautiful white ACROCIINIUM OR FVERIASTING variety of Sweet Alyssmm specially adapted to edgings, borders and rock work. Hardy ammul. Packet. $10 \mathrm{c}$.

ANEMONE (Wind Flower)

Nine inches. Poppy-like flowers in spring. The flowers are hrilliant and showy. Useful

ST BRIGID - A selection of the abore producing double and semi-double flowers in lovel

\section{ANCHUSI (Alkanet)}

Blue, star.shaped flowers from May until August.

\section{ut flowers. Tesful in Shrubbery. Pkt, 10c.
ANTIRRHINUM (Snapdragon)}

Well known showy and useful border plant, producing flowers of wrent variety-of rilliant and handsome colors; height from 2 to 3 feet. Pkt.,

ANTHEMIS (Hardy Marguerite)

Two feet. Bright vellow flowers like Daisies, Fine for cutting. Packet. $10 c$

ASPERULA (Woodruff)

Valuable for shady places. Flowers white; sweet scented.

ORNAMENTAL ASPARAGUS

PIUMOSA NANUS (IACE FERN)-One of the most popual p house plants; easily grown from seed. Graceful, spreading sprays of feathery-like upright leaves. Pkt., 10c hanging baskets. Dark-green foliage, white flowers, followed by red berries, Plit., 10c. BALLOON VINE

Annual plant, rapid grower and climber. Packet, 10 cents.

\section{BALSAM}

Double mixed. Their blossoms are brilliant and colors most vivid. They are eas. to cultivate, but do best in a rich soil, and they require plenty of water.

\section{BALSAM, APPLE AND PEAR}

Ornamental climbers, with pretty foliage and flowers, followed by handsome fruit, which, when ripe, bursts open, exposing the bright red seeds within. Ten feet.

BAISAMINA (BAISAM APPIY)-CHARANTIA (BAISAM PFAR)-Plt., 10c BELLIS (English Daisy)

Perennials which stand the winter if given the protection of a few leaves or littex; in bloom from early spring until well on in the summer. Easily raised from seed. Pkt.. 10c. BRACHYCOMB (Swan River Daisy) 


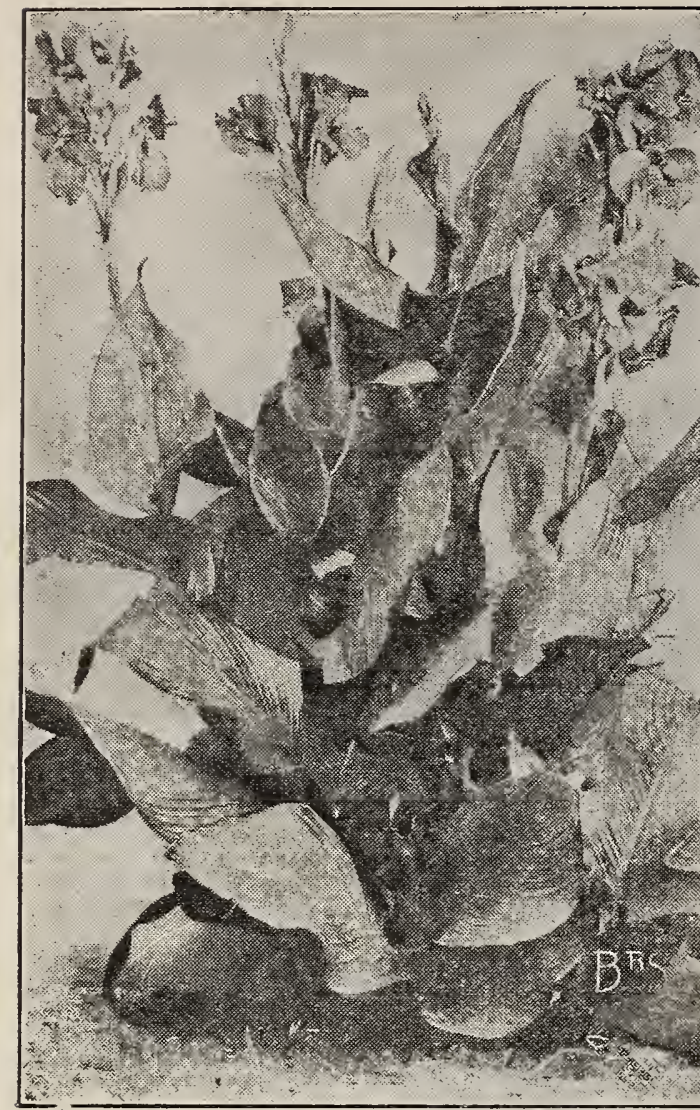

CANNA PLANT

BROWALLIA

GRANDIFIORA-A new sort; most beauti ful of all Browallias. Grow only about one foot high; form dense little bushes covered with abundance of delightful extra large sky-blue blue flowers that compares with it. Pkt., $10 \mathrm{c}$

\section{CACALIA}

COCCINEA-A handsome free-flowering little plant: owing to peculiar form of the flower is sometimes called Tassel Flower or Flora's Pain Brush. Scarlet. Pkt., 10c.

\section{CALENDULA}

Hardy annuals about one foot high, that pro duce a wonderful profusion of flowers, ranging and borders. Bloom until late fall. Belongs to the well known Marigold family. Fine mixed. many nice varieties, and when planted togethe makes a showy bed. Fine mixed. Pkt., 10

\section{CALLIOPSIS OR COREOPSIS} Very showy plants for bedding or borders,
producing in great profusion for a long time producing in great profusion for a long time Howers which are bright yellow and rich brown,
self-colored or with these colors and red contrasted, where they are to remain, and thin to one foot apart.

Sow outdoors early in spring where plants are wanted to bloom, covering seed one-half inch deep; thin to two feet apart. For earlier bloom sow indoors and transplant. Pkt., 10c.

\section{CANTERBURY BELLE}

Usually grown as a hardy biennial, but if seed is sown very early indoors it may be treated as tender annual.

Sow seed outdoors early in spring in rows about two feet apart, covering with about one fourth inch of the fine soil firmly pressed down. The plants succeed best in light, rich soil with good drainage, and in the fall should be transplanted or thinned to eighteen inches to two feet apart and given same protection in severe winter weather. Hight of plants from two to four feet. DOUBIE BLUE-Shades of blue and purple. Pkt. 10c.

SINGLE IKIXED-Colors white, and various shades of violet, rose, lilac and blue. Pkt. 5c.

\section{CANDYTUFT}

Showy, branching plants six to eighteen inches high. Indispensable for cutting and very effective in beds or masses. If sown in spring will bloc
fall will bloom from May to July. . Hardy annual.

RMPRESS-A complete mass of snowy-white flowers. Pkt., 10c.

MIXID COIORS-White, carmine, crimson, etc. Pkt., 10c.

CANARY BIRD FLOWER (Tropoeolum Canariense)

A beautiful climber with small, curiously shaped, canary colored blossoms and attractive palmate leaves.

Sow outdoors early in spring, preferably in light, moderately rich soil by the side of an arbor or trellis. Will bloom freely from July until killed by the frost. Tender annual height, 10 to 20 feet. Pkt., $10 \mathrm{c}$. GARIY DOUBIF SNOW WHITE-Pkt, $25 \mathrm{c}$

\section{CANNA}

\section{CARNATION}

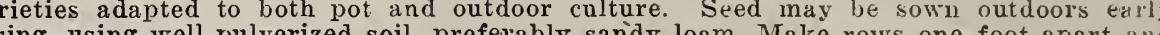
to with one-fourth inch of fine soil firmly pressed down. When two inches high. There are usually only a few flowers obtainable in the open ground the first year, but

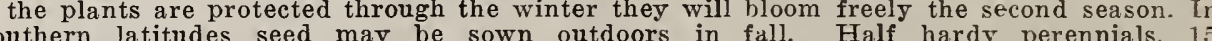

\section{CELOSIA OR COCKSCOMB}

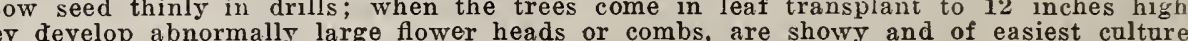
CRISTATA-The large close-headed form. Mixed colors. Pkt., 10c of being close, are loose and feathery, borne on long stems. Mixed colors. Pkt.. 10c.

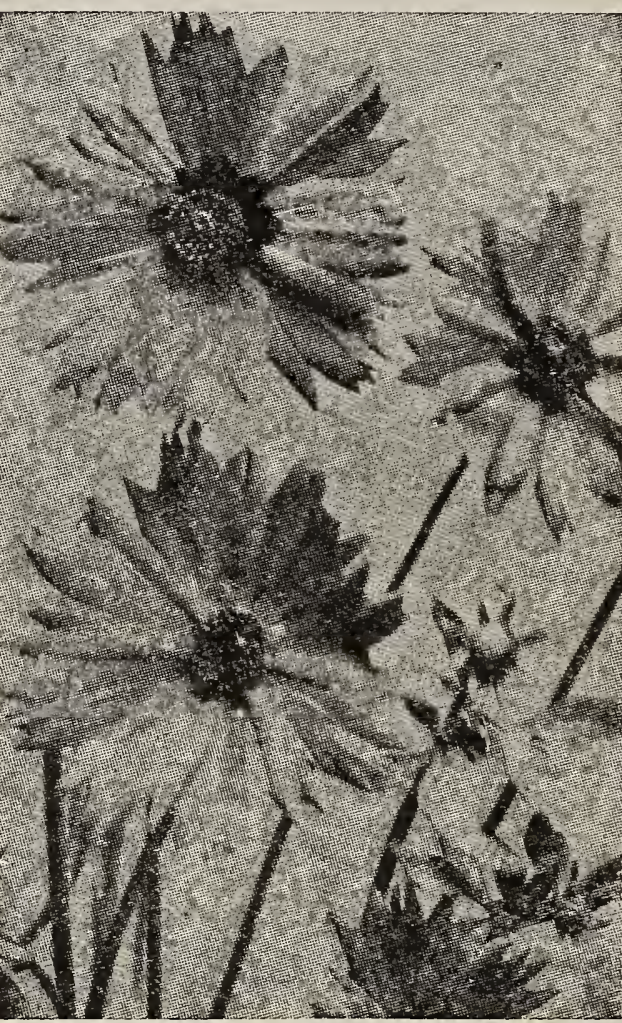

CENTUREA (Bachelor's Button)

The Centaureas are an exceedingly in eresting genus of plants. embracing an nuals, biennials and perennials, which though botanically alike, are very different in appearance. Some are very valuable for the beauty of their silvery white, velvet like foliage.

CENTAUREA CANUS-All colors mixed. Pkt., $10 \mathrm{c}$

\section{CHRYSANTHEMUMS}

A beautiful family of plants of varied character. Annuals and perennials. The towers of all are greatly prized for cutting. The annual varieties bloom profusely from early summer until frost, and their bright colors make a fine display. A little pinching back while plants are young will result in bushy and stocky growth up to 12 to 18 inches in height.

SINGIE FARIY-FIOWERING HY. BRIDS-Flowers in many shades produced very copiously. Pkt., $10 \mathrm{c}$. SINGIE MIXED-Pkt., 10c.

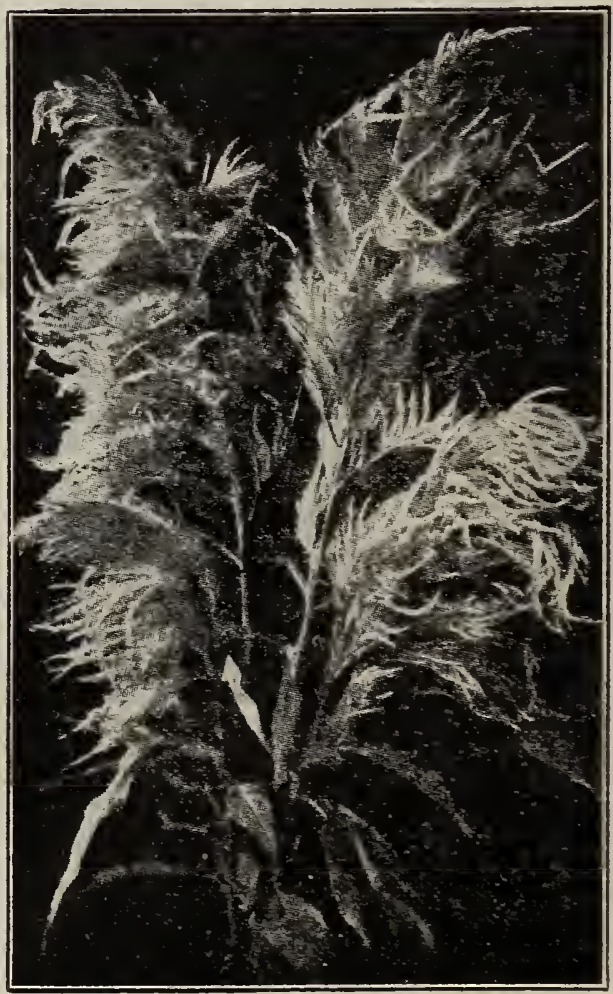

CELOSIA OR COCESCOMDB 
CHRYSANTHEMUMS-Continued.

DOUBIF MIXID-There is a wide range in the colors-from nearly white to rich deep orange. Pkt., $10 \mathrm{c}$.

FRUTESCENS (MARGUERITE, OR PARIS DAISY)-Long-stemined single white flowers, with golden centers; fine for cutting. Pkt., $10 \mathrm{c}$.

INODORUM (BRIDAI ROBE) - Pure white, extra double, compact, fine foliage; splendid for cutting. Plt., $10 \mathrm{c}$.

MAXIMUM PERERCTION-White with yellow center. Pkt., $10 \mathrm{c}$

SFASTA-Of bushy growth, bearing all summer a profusion of immense white flowers on long stems. I"kt., $10 \mathrm{c}$.

JAPONICUM - This is the seed which produces the most beautiful flowers with quilled and twisted petals, as sold by florists in fall. Pkt., $10 \mathrm{c}$.

\section{CINERARIA}

Cinerarias are easily grown from seed in the greenhouse. The large heads of brilliant daisy-like flowers of many colors, usually sharply margined and with dark eye, are very desirable in pots. The plants are often as broad as high and the velvety leaves are shaded on the under side. Sow preferably early in fall. They thrive best in a mixture of loam and peat. Perennial, usually one to two feet high. Pkt., 10c.

\section{CLARKIA}

Beautiful, hardy, annuals with rose colored, white and purple flowers, in delicate but ery brilliant shades. The plants are about one and one-half to two feet high and are profuse bloomers.

Sow in light, warm soil, as early in the spring as the ground can be worked, or if planted in August they will bloom the following summer. DOUBIE MIXED-Pkt., $10 \mathrm{c}$

\section{CLEMATIS FLAMMULA}

\section{(Virgin's Bower)}

A small leaved variety of the Clematis family which grows very quickly and is covered with small star-shaped white blossoms which are very fragrant. Most excellent for trellis, bowers, summer houses and very pleasing where loose hanging vines are desired. Pkt., $10 \mathrm{c}$.

\section{COBAEA SCANDENS}

A fine rapid growing climber with hand. some dark green foilage and bearing on graceful stems large, bell-shaped flowers, green at first, but rapidly changing to a beautiful deep violet-blue. Tender perennial. Pkt., 10c.

\section{COLEUS}

Magnificent ornamental foliage plants for house or garden culture.

Sow in shallow pots in rich light soil. Cover the seed lightly with eartl and keep the plants in an even moist temperature. Transplant to the open ground in bed or border as soon as danger of frost is over.

FINEST FYBRIDS, IIXID - Extra choice. Pkt., $10 \mathrm{c}$.

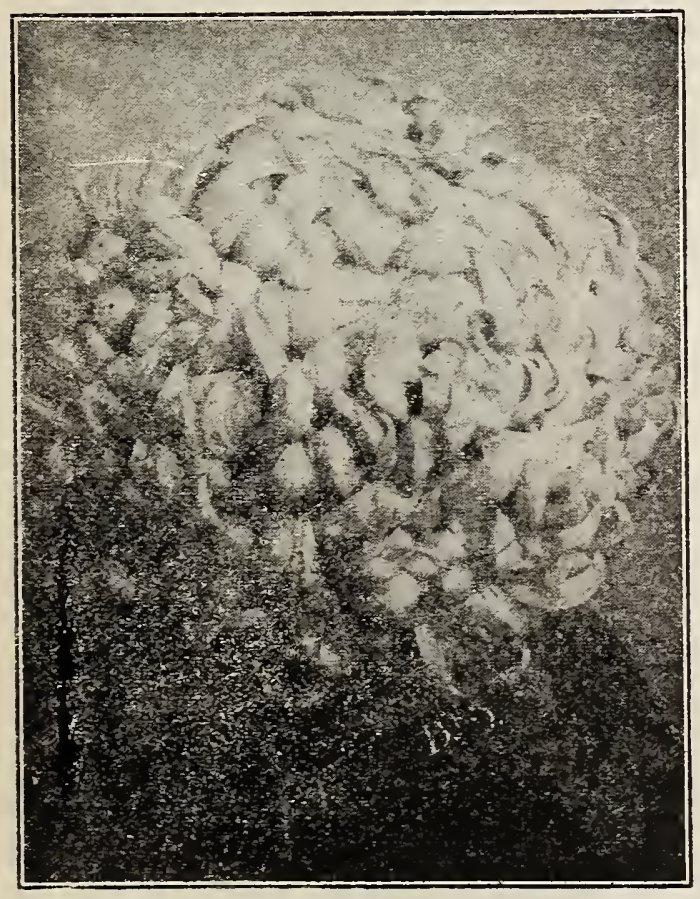

CHRYSANTHEMUM (MARGUERTTE)

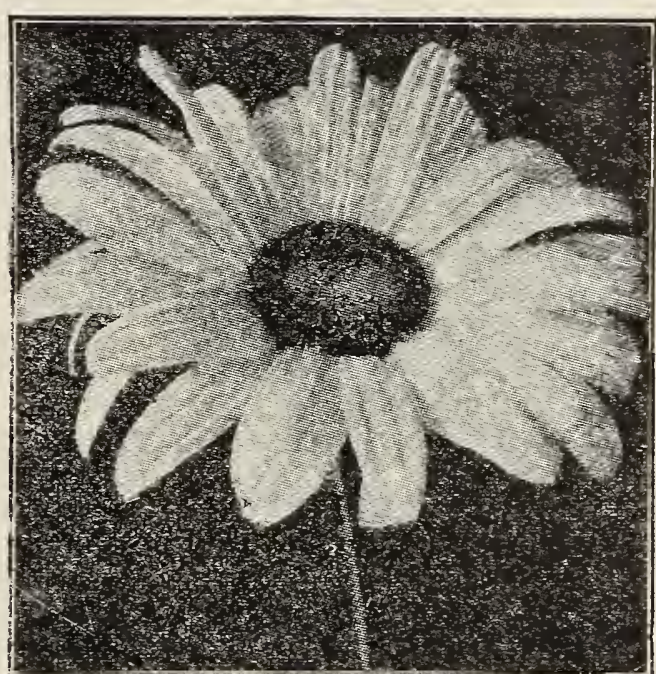

SHASTA DAISY

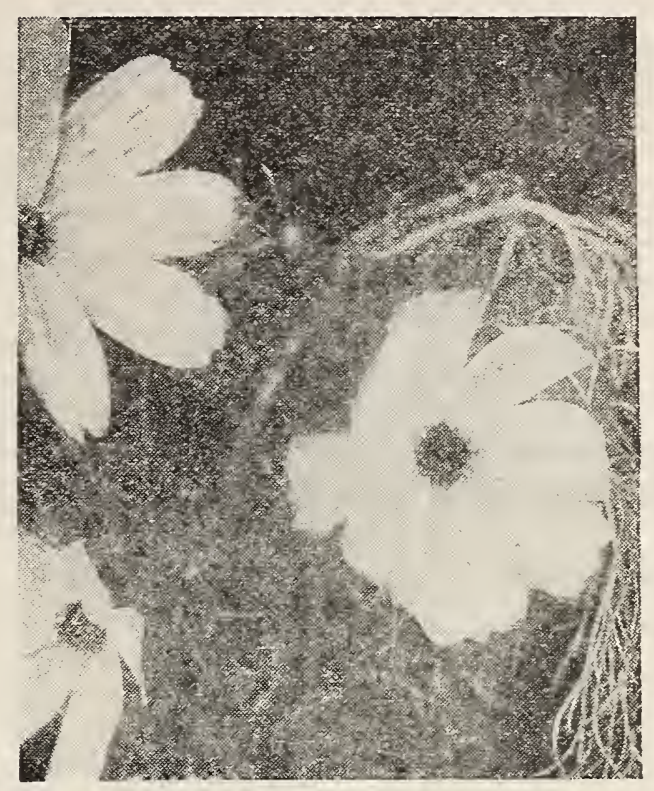

EARIY FLOWERING COSMOS COSMOS

A hardy and rapid growing annual, rorming bush-like plants with feathery green foliage, four to six feet high, covered with large flowers somewhat resembling the single dahlia. They are gracefully poised on long

Sow outdoors early in spring in rather light soil, not too rich, and preferably in a sunny soil, not too rich, and preferably in a sunny one-half inch of fine soil firmly pressed down. If planted in rows, make the rows about two feet apart and when the young plants are well feet apart and when the young plants are
up thin from 4 to 6 inches apart in the row.

FARIY FIOWDRING DAWN-Flowers are white, Pkt, 10c.

FARIY FLOWERING MIXIDD-Include white, bright red and rose colored flowers. Pkt., 10c.

FYBRIDA, GIANT WHITE-Pkt, 10

FYBRIDA, GIANT PINK-Pkt., $10 \mathrm{c}$.

IYYRIDA, GIANT MIXID-Flowers white and in shades of pink, rose and maroon. Pkt., COLUMBINE (Aquilegia)

Very desirable, easily grown, old fashioned perennials for borders, forming large permanent clumps. Sow the seed, which is of rather slow germination, in open ground early in spring in ans rich, well drained garden soil. Pkt., 10c.

\section{CYCLAMEN}

Well known and universally admired tuberous rooted pot plants, producing exeedingly handsome red and white flowers for indoor or spring blooming in greenhouse or window garden. Pkt., $10 c$

\section{CYPRESS VINE}

A most beautiful rapid growing climber with delicate dark green, feathery foliage and many bright, star-shaped, scarlet or white blossoms, which contrast most effectively with the graceful foliage. Planted by the side of veranda, tree or stakes and trained properly. there is no climber more handsome.

Seed is usually sown outdoors early in spring in the row where the plants are to remain. Cover seed one-half inch deep.

SCARIFT-A very deep, rich shade. MIXED-The two colors above. Pht., 5c.

\section{DAHLIA}

$V$ ery easily grown from the seed, and blooms the first season. The earlier they are started, the better, which can be done nicely in a box in sunny window or greenhouse. DOUBIE, MIXgD-In, all colors. Pkt., 10c.

\section{SHASTA DAISY}

Charming little plants for edgings and borders, also used for low beds and rock work. The flowers of the improved varieties we offer are borne above the low cluster of leaves on stiff flower stalks, making them suitable for bouquets. With careful cultivation mearly eventy-five per cent are double.

For best results sow seed in hotbed and when plants are large enough transplant to a rich soil in a cool and partially shaded situation, setting the plants six inches apart. If plants are started early indoors they will flower the same season, but bloom more abundantly in the spring if sown in autumn and the plants wintered over in cold frames: or can he set out in the open border and protected with mulching. Half hardy perennial; about six inches high. Pkt., $10 \mathrm{e}$ 


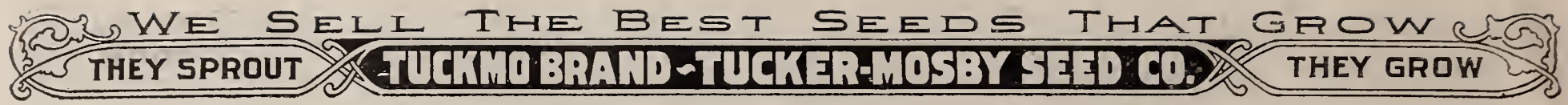

\section{DAISY - Continued}

DOUBIF ROSE-Finest strain; the Howers are double and rose colored. Pkt., 10c. DOUBIE WIITE-Very double, clear white. Pkt., 10c.

\section{DATURA}

Large branching plants, producing very large, handsoine, double or single, trumpet shaped lossoms of exquisite fragrance. Excellent for late summer and autumn flowering.

Seed may be sown outdoors after danger of frost is over, but for easly blooining, sow in otbed and transplant about three feet apa

cellars. Tender annual; three feet high.

WRIGHTI-Pure white at the center, shaded into lilac and blue: magnificent large single towers. In war'm latitudes can be continued as a perennial. Pkt., 10c.

\section{DELPHINIUM (Larkspur)}

Quick growing, vert free flowering annual, producing erect spikes of beautiful flowers of arious colors. Sow in early spring, thinly, in shallow drills. Thin out after well up, to 10 to 12 inches apart. This makes a pleasing lisplay and is very satisfactory.
CFIORANTHA, FI. PI. (MUMIIS FIAVA)-Large, usually double rellow, richly DEIPHINIUM, DWARF DOUBIE MIXIPD-Of rather dwarf growth, 10 to 11 inches high. The branching spikes are thickly set with donble flowers of many distinct colors. Plit. DFIPHINIUIV, TAII, DOUBIE MIXED spikes are profusely covered with fully doul

DIANTHUS OR GARDEN PINK

A mannificent genus of plants, annuals and perennials, entracing some of the nost popula

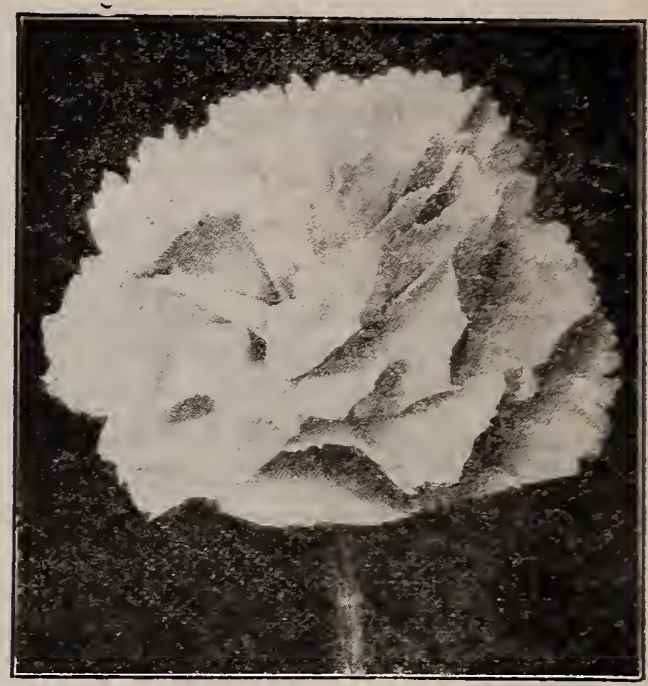

DIANTHUS OR GARDEN PINK
Howers in cultivation, producing a great variety of
The Chinese and Japanese varieties bloom the first season, the same as hardy annuals; height, 1 foot. season, the same as hardy annuals; height, 1 foot. The hardy perennial varieties are very fragiant

f easy culture for the garden or greenhouse.
Many of the flowers have fringed edges. The color. ing of all is beautiful, varied and unique. Pinks ar. flowers for everybody; they will thrive almost every-
where, and they remain in bloom a length of time. ROYAI PINKS-These very large, single flowers afford a wide range of color. Petals deeply cut and afford a wide range of color. Petals deeply cut and red to carmine, pink, even white. Plants dwarf and very free flowering. Pkt., $10 \mathrm{c}$.

SINGIE MIXED-A splendirl mixture of single Howers of the best shades and beantifully marked. Plants dwarf; very free tlowering. Pkt., 5 c. variety easily cultivated; rich, deep red fowers. DOÜBIE DARK PURPIP-An attractive and particularly useful color in pinks. The flowers are
louble, of large size, fine forlin and are suitable for cutting. Pkt., 10c. Very regular, double and all tints from crimson pur ple to deep black purple. Pkt., 10c.
DOUBIE JAPAN MIXIDD (CHINENSIS CINIATUS)-The flowers are rich in hut: rery

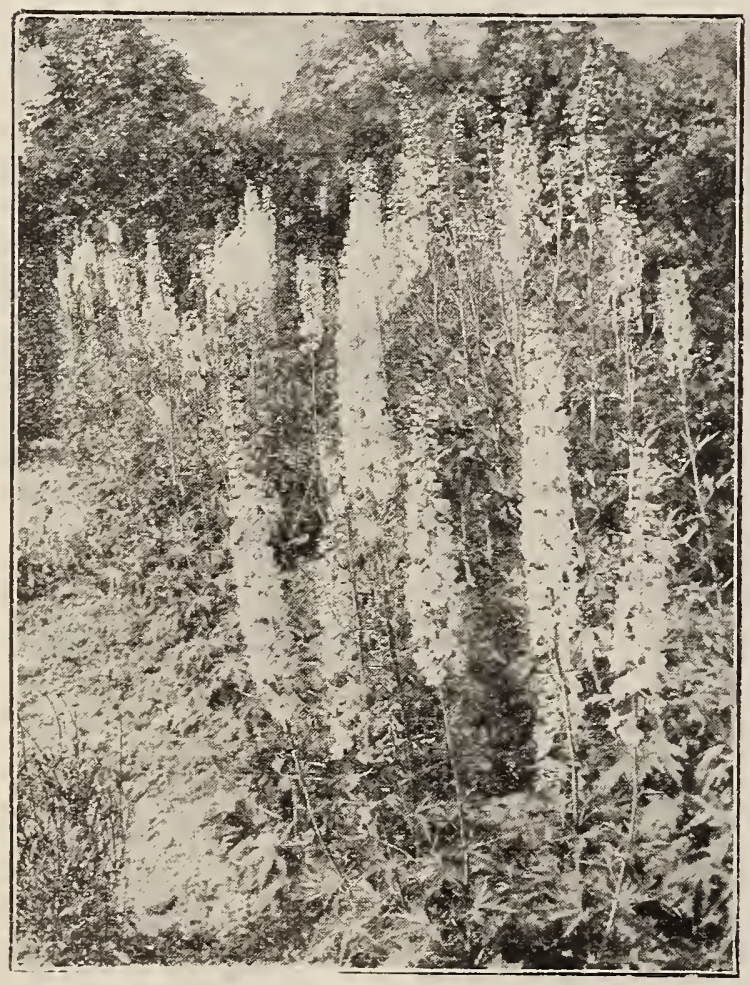

DELPGINIUM OR IARKSPUR

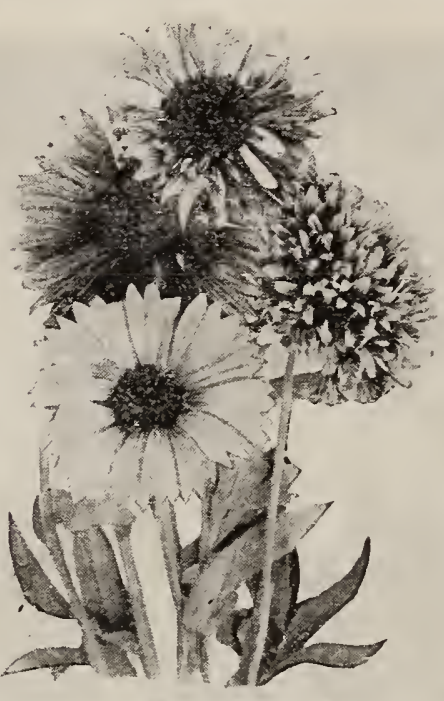

rose, lilac, carmine, crimson, scarlet, purple, brown DOUBIE CHINA MIXED (CHIN⿴NSIS)-White and dark crimson, also white tipped light purple and shades of red with darker blotchings. A mixture of double pinks unsurpassed in variety of brilliant color-

SNOWDRIFT-Clear. white, double and fully as large as the popular Marguerite Carnation; desirable for cutting. Pkt.. 10c.

\section{DIGITALIS (Foxglove)} Hardy perennial plants, useful as the background
of the shrubbery border. They attain a height of 2 to 3 feet. Rich. loamy soil and partial shade suit FIN E NIXID-Pkt., $10 \mathrm{c}$

DOLICHOS (Hyacinth Bean)

A showy annual climber, grows luxuriantly about 10 feet high, branching out well from the bottom. and is clothed with dense foliage; insect proof, and forms excellent screens as well as heing exceedingly ornainental. The sweet pea-like hlossoms are borne in long, wistaria-like clusters, often a foot in length. which are followed ly exceedingly ornamental seed jods. Plit, 10e.

\section{ECHEVERIA (Hen and Chickens)}

Four inches. The rosette-like plants are largely ased in parks and cemeteries for carpet bedding Seeds are very small. Pkt., 10c.

ESCHSCHOLTZIA (California Poppy)

of California. A genus of the Poppy family fully as valuable as for garden ornamentation, as it blooms almost continually throughMIXED COIORS-White. yellow and orange. Pkt., 10c.

EVERLASTINGS

A group of annual plants whose flowers are cut when nearly at full bloom. Will grow in any common garden soil rears thereafter. They will thrive in any sumny good soll.

FPECIAI MIXTURE-A single packet will give in abundance a great variety of the

EUPHORBIA (Snow on the Mountain)

Hardy annual, growing about two feet high. Useful in shrubbery borders.

VARIFGATA-Leaves veined and margined with white. Pkt., $10 \mathrm{c}$

DUSTY MILIFR-Silver foliage, delicately cut. Height, $1 \frac{11}{2}$ feet. Excellent for rases or edgings of beds. Pkt.. 10c.

\section{GAILLARDIA}

Desirable ledding plants and excellent for cutting. Flowers are of brilliant and GERANIUMS

These popular plants are most easily raised from seed, and if started early will proace flowering plants the first sunmer. Start in the house and transplant to the arden as soon as the weather is warm. Pkt, $10 \mathrm{c}$

\section{GILIA}

Free-flowering, hardy amnuals, one foot to eighteen inches high, with finely cut foliage and clusters of small, delicate flowers. white, blue, lilac and rose color: GOURDS (Ornamental)

A climber; quick-growing vines, excellent for covering arbors, walls and waste places. Gourds grow in very curious shapes and are used for house ornaments. CAIABASH or PIPE GOURD-Plt., jc. DISH CIOTH-Like a sponge. Pkt., 5 DIPPER-Always useful. Pkt., 5e. NEST EGG-Mar be used as such. Pkt., 5e 


\section{Tucker's Blue Ribbon Early White Corn}

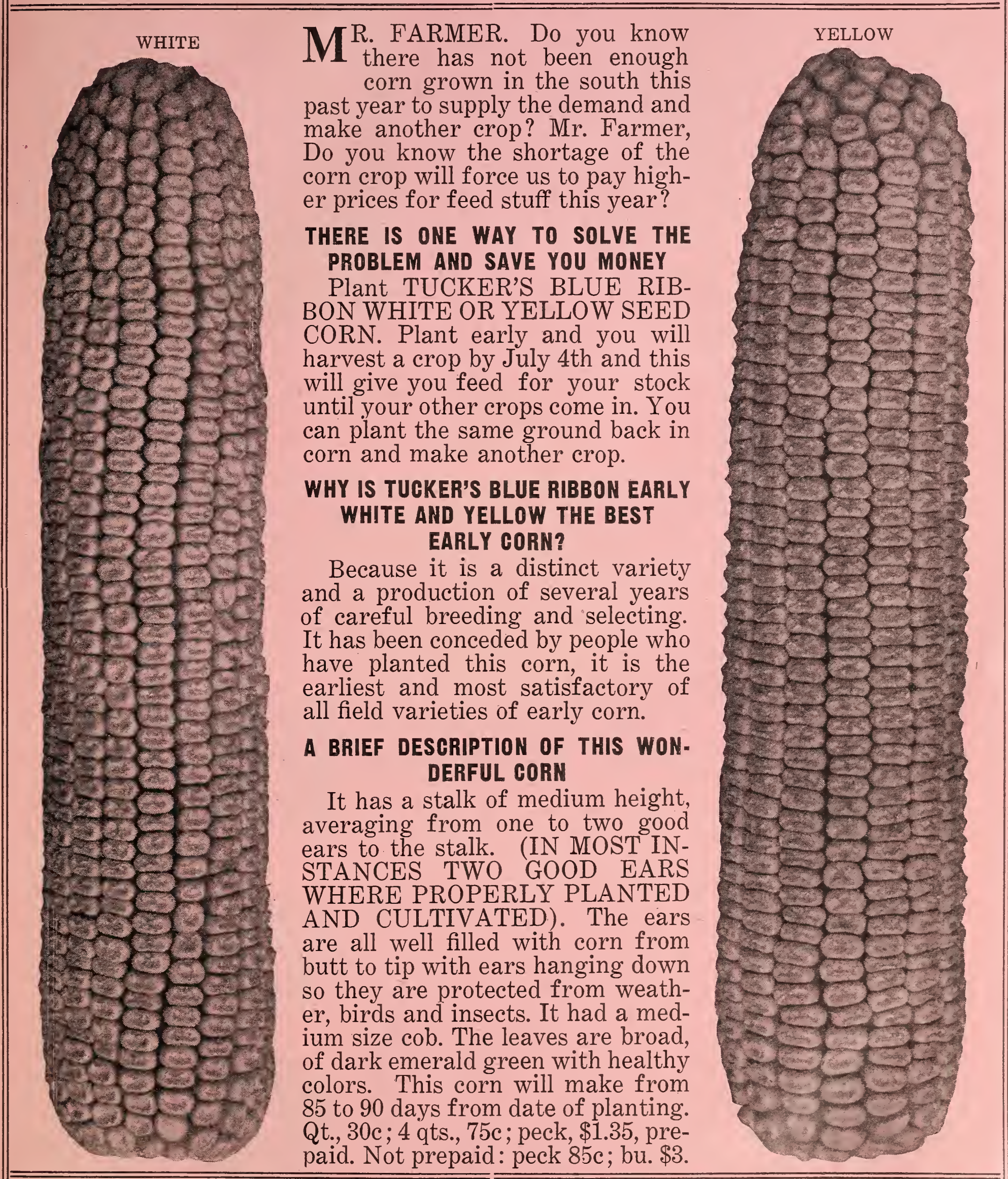

\section{Tucker's Blue Ribbon Early Yellow Corn}




\section{Tuckmo Delfos Cotton}

An Early Maturing Cotton

Is a production of an experienced agriculturist, a man who has made a long study of developing cotton. Tuckmo Delfos is one of the earliest maturing staple varieties grown, making a staple on good rich or bottom land from 1 3-16 to 1 1-4 inch. In many sections where the conditions were unusually dry this past year Tuckmo Delfos Cotton made an average staple to $13-16$ inch and a production of 1600 lbs. of seed cotton made a $510 \mathrm{lb}$. bale of lint cotton. Last year one of our customers

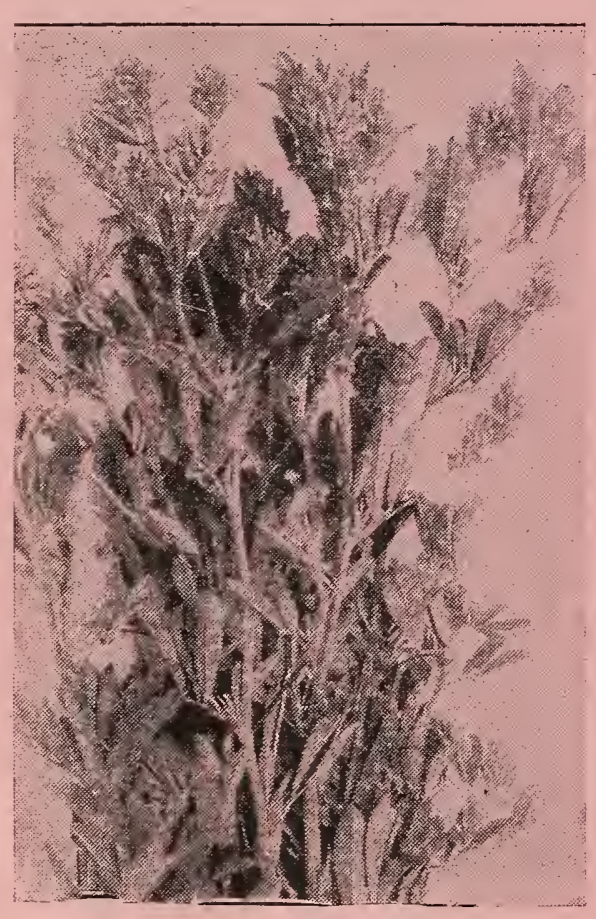

purchased 7 bushels of seed and made nine bales which weighed $535 \mathrm{lbs}$. each. We have

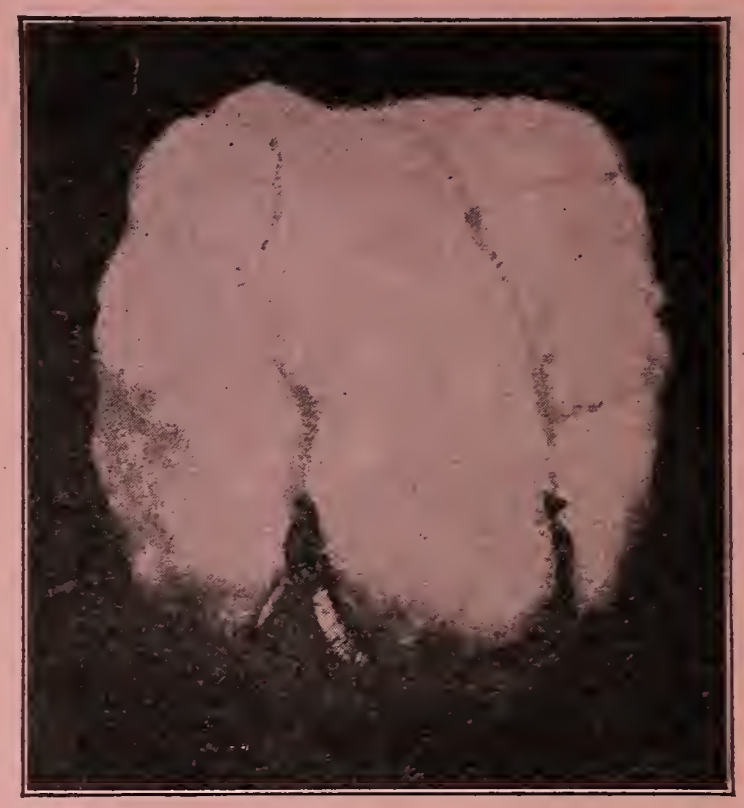
only a limited quanti-

ty of this fine seed and would suggest sending your orders early. Price: bushel (30 lbs.), $\$ 5.00 ; 100$ lbs., $\$ 15.00$, F. O. B. Memphis.

\section{Tuckmo Dakota No. 12 Alfalfa} The Best Alfalfa for the South

Since this great Alfalfa has come into such prominence and has been conceded by the greatest agriculturist as the best alfalfa for the south, we have put forth our efforts and have selected the most logical place to secure our seed. TUCKMO ALFALFA has an upright growth with long tap roots which enables it to stand more wet weather; more cold weather; more hot dry weather than any other kind. See page 52 for cultural directions. Price: 40c per lb., not prepaid, per pound 35c. In $100-1 b$. lots, 30c per lb.

\section{Fill Your Corn Crib}

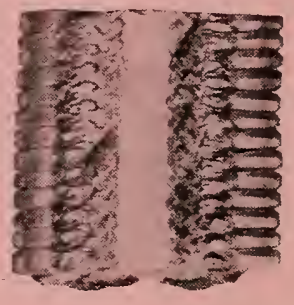

\section{With Mosby's Prolific Corn}

And you will have plenty of Corn for your stock next year. IT MAKES FINE MEAL FOR TABLE USE. It is a producer on good land, making three to five good ears to the stalk, small cob, moderately deep grain, well filled from tip to butt. The stalk is of an average size making an abundance of fodder. It matures in 115 to 120 days from planting. IF YOUR CORN CRIB IS FILLED WITH MOSBY'S PROLIFIC CORN "YOU WILL HAVE SOME CORN" and you will not have to buy from your neighbors or send away and get it. YOU WILL HAVE CORN TO SELL. Price: Quart, 35c; 4 quarts, $\$ 1.00$; peck, $\$ 1.50$, postpaid. Not prepaid: peck, $\$ 1.00$; bushel, $\$ 3.50$.
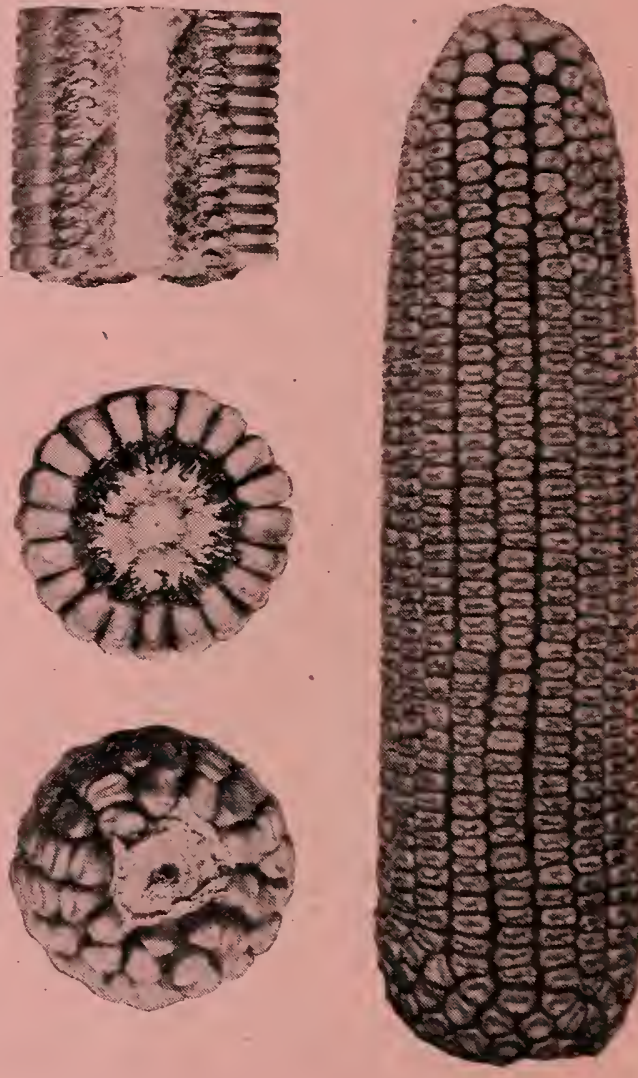


\section{TUCKMO VEGETABLE SEED COLLECTIONS}

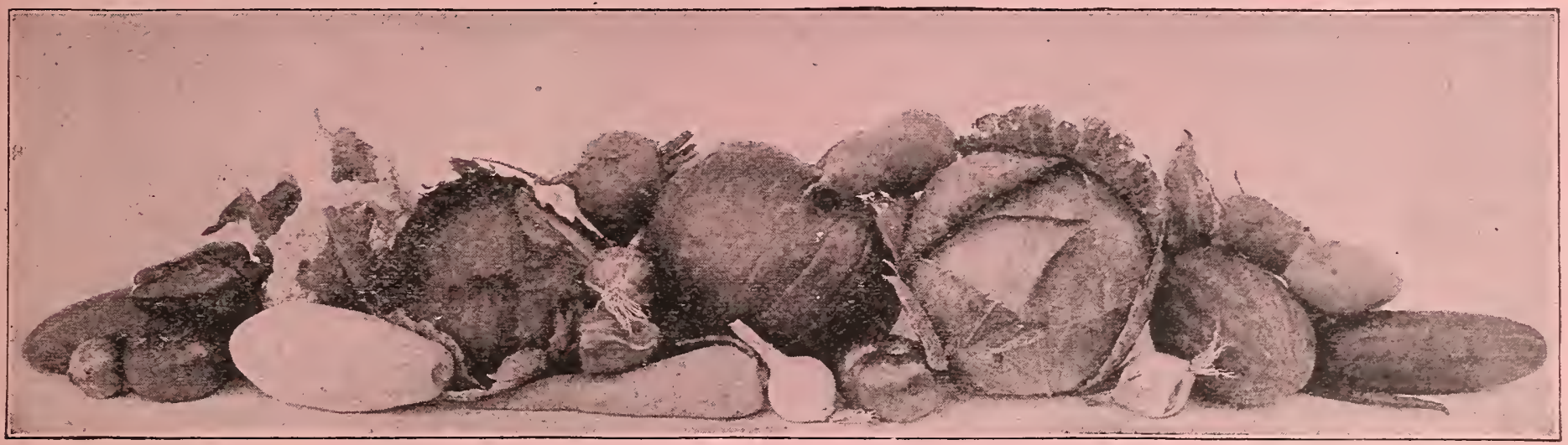

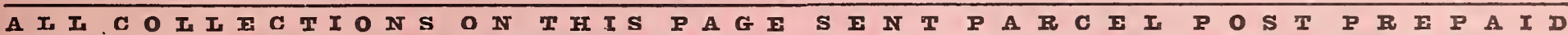

25C TUCKMO GOLLEGTION $25 \mathrm{C}$

1 Paper Beets, Early Blood Turnip

1 Paper Radish Farly Scarlet Turnip

1 paper Mustard, So. Giant Curled

1 Paper Lettuce, Big Boston

1 Paper Cucumber, Long Green

1 Paper Squash, White Bush

1 Paper Tomato Early Acme

1 Paper Spring Turnips

The above amount would be $40 \mathrm{c}$ if selected separately from Catalogue.
$50 c$

TUCKMO FIFTY.GENT GOLLECTION

$50 c$

\section{$\$ 1.00$}

1 Pkt. Cucumber, Long Green

1 Pkt. Squash, White Bush

1 Pkt. Cabbage, J. W.

1 Pkt. Cabbage, Early F. D.

1 Pkt. Tomato, Acme

\section{T U C K M O}

\author{
1 Pkt. Lettuce, Big Boston \\ 1 Ilst. Okra. W. V. \\ 1 Pkt. Cal'rots, L. O. \\ 1 Pkt. Peas, Alaska \\ 1 Pkt. Beans, Red Valentine
}

1 Pkt. Peas, Alaska

1 Pkt. Tomato, Acme

1 Pkt. Turnips

1 Pkt. Cabbage, J. W.

1 Pkt. Squash, W. B.
1 Pkt. Beans, Red Valentine

1 Pkt. Radish, Round Red

1 Pkt. Mustard, Curled

1 Pkt. Cucumber, Long Green
1 Pkt. Lettuce, Big Boston

The above amount would be $75 \mathrm{c}$ if selected separately from catalog.

1 Pkt. Beans, Ky. Wonder

1 Pkt. Corn, Golden Bantam

1 Pkt. Radish, Scarlet Turnip

2 Pkt. Mustard, Curled

2 Pkts. Turnips, Spring

1 Pkt. Beets, Blood Turnip

THE ABOVE AMOUNT WOULD BE \$1.25 IF SELECTED SEPARATELY FROM OUR CATALOGUE.

\section{$\$ 2.00$}

2 Pkts. Beans, Red Valentine

1 Pkt. Beans, Ky. Wonder

1 Pkt. Beans, Lima, Small Pole

1 Pkt. Corn, Golden Bantam

2 Pkts. Beets, Blood Turnip

2 Pkts. Cabbage, J. W.

2 Pkts. Cabbage, Succession

2 Pkts. Cabbage, Flat Dutch

THE ABOVE AMOUNT WOULD BE \$2.50 IF SELECTED SEPARATELY FROM CATALOGUE

BE 1.25 IF SHLECTED SEPARATELY FROM OUR CATALOGUE. 


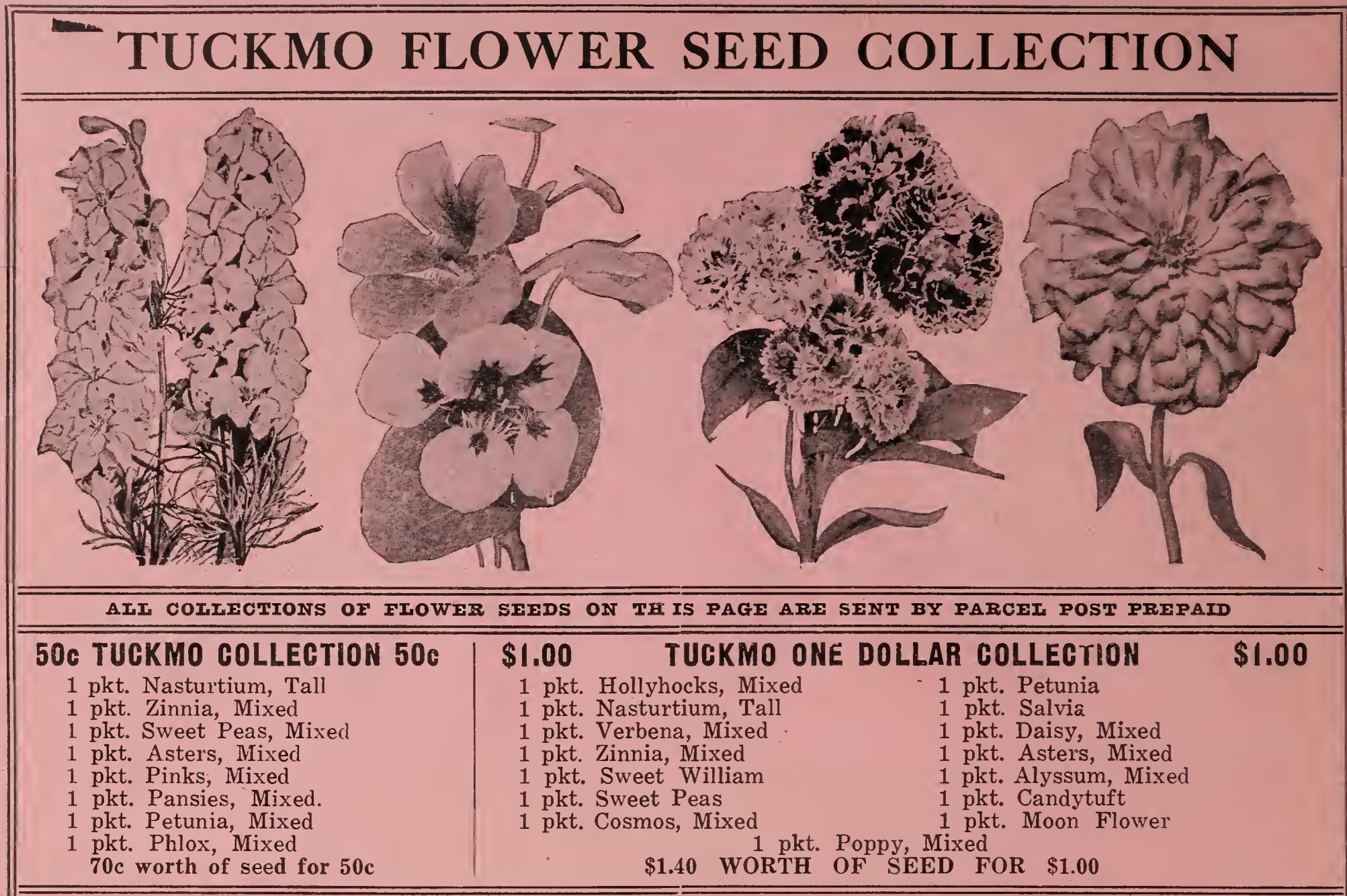

$\$ 2.00$

TUCKMO TWO DOLLAR COLLECTION

$\$ 2.00$

1 pkt. Asters, Mixed.

1 pkt. Carnation, Mixed

1 pkt. Larkspur

1 pkt. Poppy, Mixed

1 pkt. Moon Flower

2 pkts. Nasturtium, Tall

2 pkts. Nasturtium, Dwarf
1 pkt. Snapdragon

1 pkt. Verbena Mixed

1 pkt. Alyssum, Mixed

1 pkt. Cosmos, Mixed

1 pkt. Pinks

1 pkt. Hollyhocks (\$2.50 WORTH
1 pkt. Morning Glory 1 pkt. Pansies, Mixed.

1 pkt. Phlox

2 pkt. Sweet Peas, Mixed

1 pkt. Balsam, Mixed

1 pkt. Daisy, Mixed

\section{TUCKMO B ULB COLLECTION S}

\section{$\$ 5.00$ TUGKMO COLLECTION $\$ 5.00$}

3 Dahlias, Red

3 Dahlias, Yellow

3 Dahlias, White

3 Peonies, Red, White,

Yellow

$\$ 6.10$ WORTH OF BULB'S FOR

12 Gladiolus, Mixed

6 Cannas, Mixed

6 Caladiums, Large Size

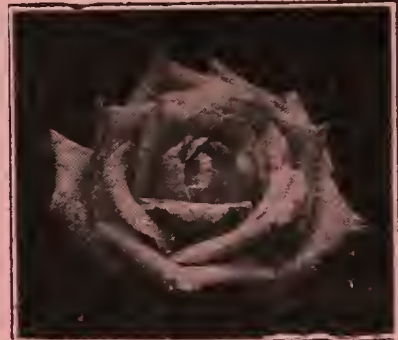

TUCKMO ROSE COLLECTION $\$ 5.00$ TUCKMO COLLECTION

1 American Beauty

1 Killarney

1 Sunburst

1 Baby Rambler

1 Rosa Rugosa

1 Etoile De France

$\$ 6.00$ WORTH OF BEAUTIFUL ROSES FOR $\$ 5.00$

\section{$\$ 10$ TUCKMO COLLECTION \$10}

12 Cannas, Assorted 2 Peonies, Red

6 Caladium, large size 2 Peonies, Pink

12 Gladiolus, assorted 12 Tuberoses

2 Lily of the Valley

Dahlias, Yellow

$\$ 11.35$ WORTH OF BULBS FOR $\$ 10.00$

\section{$\$ 10.00$ \\ TUCKMO TEN DOLLAR ROSE COLLECTION}

$\$ 10.00$

1 Duchess of Wellington

1 La France

1 Excelsa

1 Dorothy Perkins ROSES AND FRUIT
1 Estoile De France

1 Paul Neyron

\section{TUCKMO FRUIT COLLECTION}

TUCKMO COLLECTION $\$ 5.00$

1 Peach, Mayflower

1 Peach. Elberta

1 Pear, Barlett
1 Plum, Wild Goose

1 Apple, Winesap

1 Cherry, Early Richmond $\$ 6.70$ WORTH OF FRUIT TREES FOR \$..00 


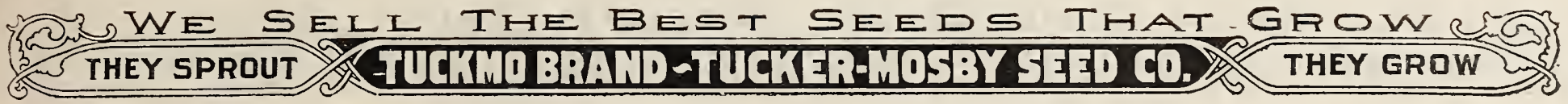

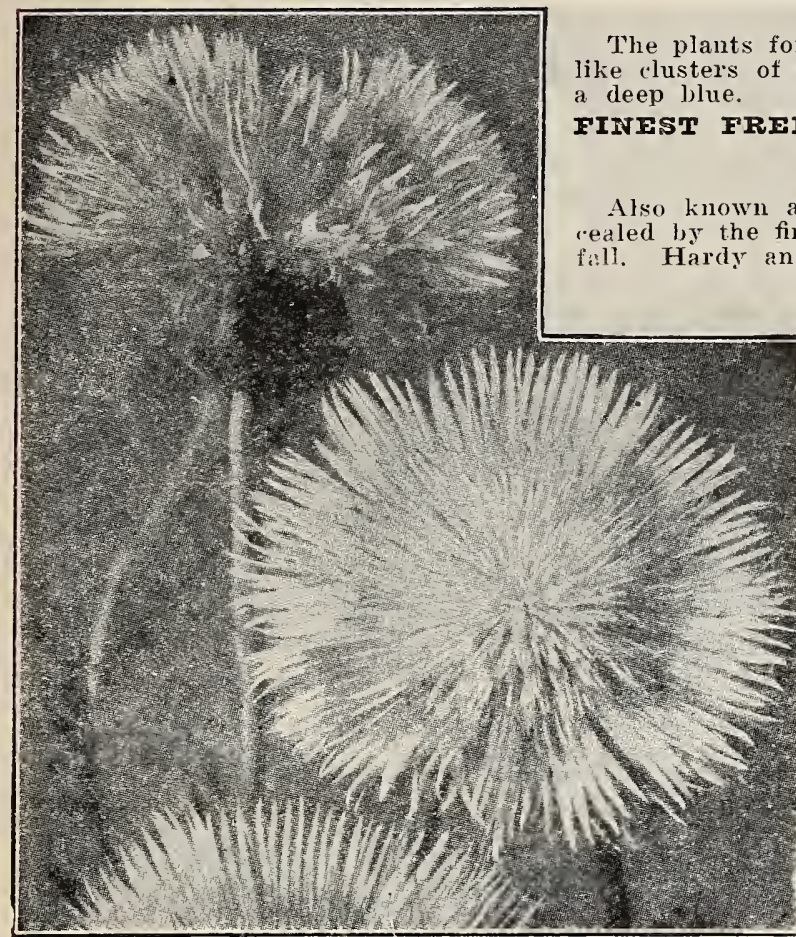

IMPERIAI SWEET SUITAN
Ornamental Gourds-Continued SUGA.R TROUGH - For buckets. GOÜRDs-Mixed. Pkt., 5c. HERCUIE's CIUB -, Sometine grows three feet long. Pkt.
GYPSOPHILA

Delicate, free-flowering plants covered with star-shaped flowers, valuable for mist-like effects and as trimming in bouquets; also for hanging baskets or edgings. Sometimes calle any well prepared gronud. handsome prepared gron.

EIFGANS IARGE FIOWERING PURE WHITE-An improved large flowered strain, superior to the common Elegans, not only in size of flower, but also in color. A very charmsing sort for combining in bouquets with sweet peas or other cut flowers. Pkt., 10c.

FIEGANS InIXFD-Very small, delicate white and rose-pink flowers. HELIOTROPE

Sown early, blooms same season: 2 feet. Excellellt for bedd

MAMMOTH FUOWRRED - This strain gives flowers almost twice the size of others. Colors from almost white to deep dark purple. Pkt., $10 \mathrm{c}$. colors. Pkt., $5 \mathrm{c}$

HOLLYHOCK (Althaea Rosea)

Sow seed in June or July in open ground and in the autuinn, when plant have made five leaves, transplant to perm anent position two to three feet apart. All double varieties are hardy anuuals: five feet high.

EARIY FIOWFRING-Blooms read. ily as an annual the first year from seed sown in spring. A wide range of colors in large single or semi-double flowers. 10e. FINEST MIXED-Double perfect. DOUBLE BLOOD RED.

DOUBIF IFMON-YEIIOW.

DOUBIE PINK.

DOUBIE SAIMON-Ricl salmon col-

DOUBLE PURE WHITE-Our special DOUBIE CHOICE MIXED-All colors Price of above-Per pkt., 10c.

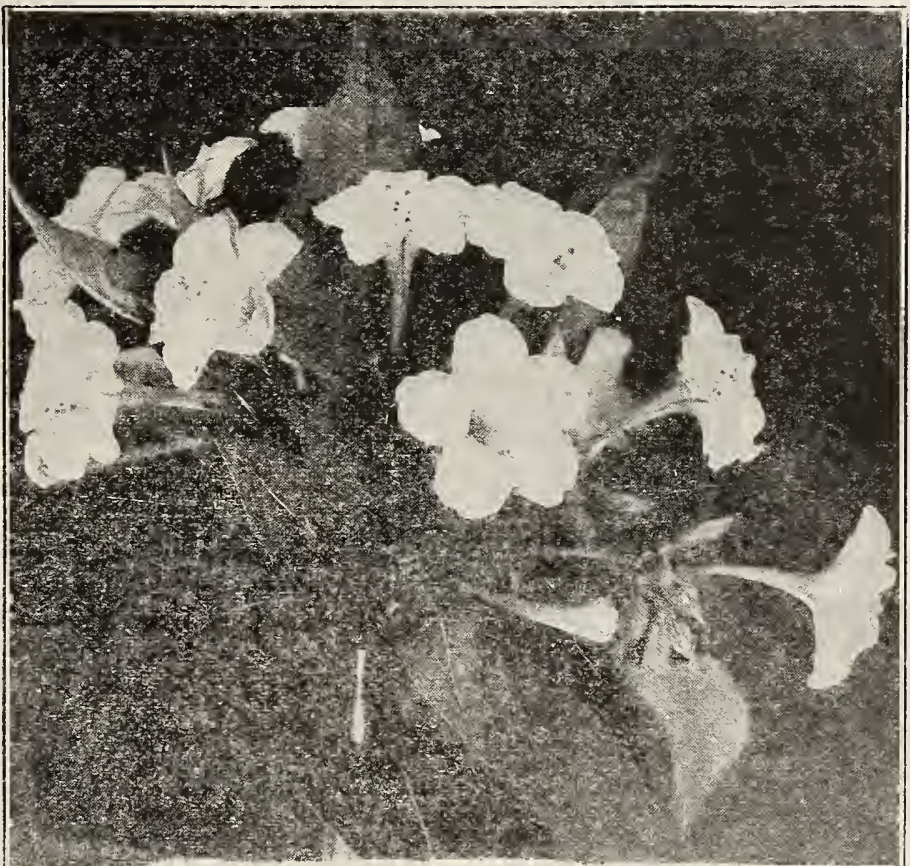

FOUR O'CIOCK, MARVIT OF PERU

IMPERIAL SWEET SULTAN

(Centurea Imperialis)

These beautiful giant-flowering "Sultans", are grand in rovements over the old varieties. They produce long-stem med, exquisite fringed blossoms three to four inches acros of graceful effect and are delightfully fragrant. The color vart from white and yellow through reds from pinks to crimon and through blues from lilac to purple, some having cen ters of a different color, as violet with white centers, ete. For bouquets, vases, etc, they are exceptionally beautiful. If cut scarcely opened they will last for ten dass in water. The plants are of the easiest culture, flowering freely in the garden from seed sown in the spring.
2 to 3 feet high. Plit.

\section{ICE PLANT}

A handsome and curious plant for hanging baskets, rockwork and vases. The leaves and stems appear as though covred with ice crystals. The whole plant is peculiarly. KUDZU VINE (Jack and the Bean Stalk)

It is a rapid-growing vine very hardy. Its foliage is ver luxuriant and its rose-colored fragrant flowers are produce in large clusters. There is no climber can eriual it. Plit, 10

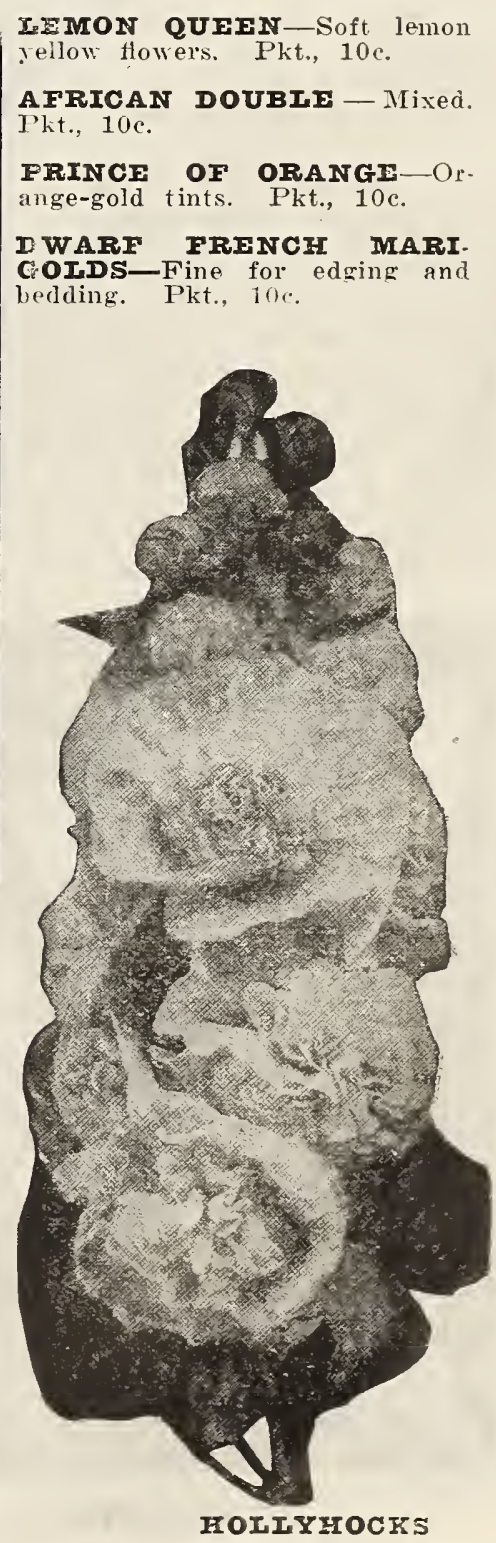




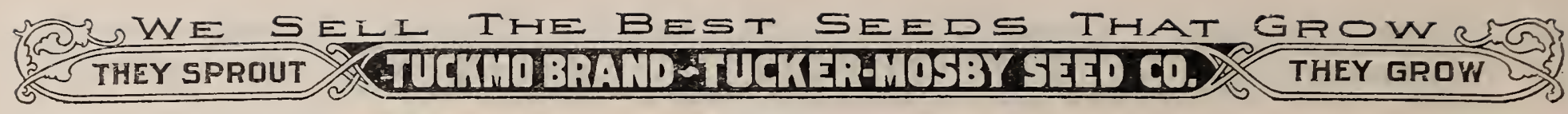

MARIGOLD-Continued IEGION OF HONOR-Single, golden yellow, blotched, variety crimson.
Pkt., 10c.

DWARE GOID STRIPED.-Very double Chestnut brown, striped yelFRENCF DWARF DOUBLE, MXID-Pkt., 10c.

\section{MATRICARIA (Double Feverfew)}

CAPEISIS-18 inches. Blooms first year from seed if sown early. A fine bedding or pot plant, bearing white flowers in profusion all summer. Pkt., $10 \mathrm{c}$. MAURANDIA-10 feet. Climbers with slender vines and neat, pretty flowers. Bloom freely in the garden all summer. Especially adapted to hanging baskets and window boxes. Mixed. Pkt., $10 \mathrm{c}$.

\section{MIGNONETTE (Reseda Odorata)}

Twelve to eighteen inches. If successive sowings are made, its fragrant, inodest-colored flowers may be gathered outdoors until November. Sow in pots or boxes under glass in February or March, and thin or pot off the seedlings to make good plants for bedding out in April. Sow outdoors in rous about April 1, and again regularly at intervals of about three weeks until August.

AIIEN'S DEFIANCE-Grows under favorable conditions, this variety makes spikes a foot long, and the individual flowers are not only very large but delightfully fragrant as well.

GABRIgIE-Red flowers; desirable in gardens. Pkt., 10c.

GOIDEN QUEEN-A distinct color; sweet.
Plit., 10c.
BISMARCI-Red; crinkly foliage, fragrant.

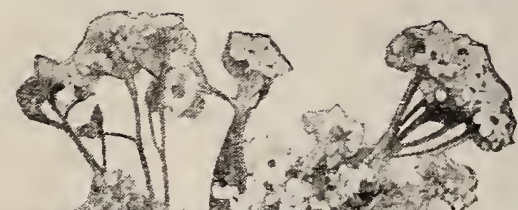
Pkt., 10c.

GOIIATH-Rich green foliage; giant trusses of red flowers on strong stems. Pkt., $10 \mathrm{c}$. MACHFT-One of the best of the family. Of dwarf habit with very large red flowers

and handsome foliage. Plit.

MIMOSA (Sensitive Plant) PUDICA-18 inches. Its fern-like and drooping when touched. Pkt., 10c.

\section{MOON FLOWER}

One of the most vigorous summer
limbers and will grow under favorable onditions thirty to forty feet in a single eason and be covered evenings and cloudy days with very large, white trumpet-shaped flowers, widely extended, often four inches across. Leaves large, frequently four to five inches across. The hard outer coat of the very large, light vellow seed should be cut through with sharp knife, care being taken not to cut any deeper than the hard shell and cut any deeper than the hard shell and the seed planted about one inch deep in moist soil in a box or pan and set in a
warin place. If soil be kept moist, germ-

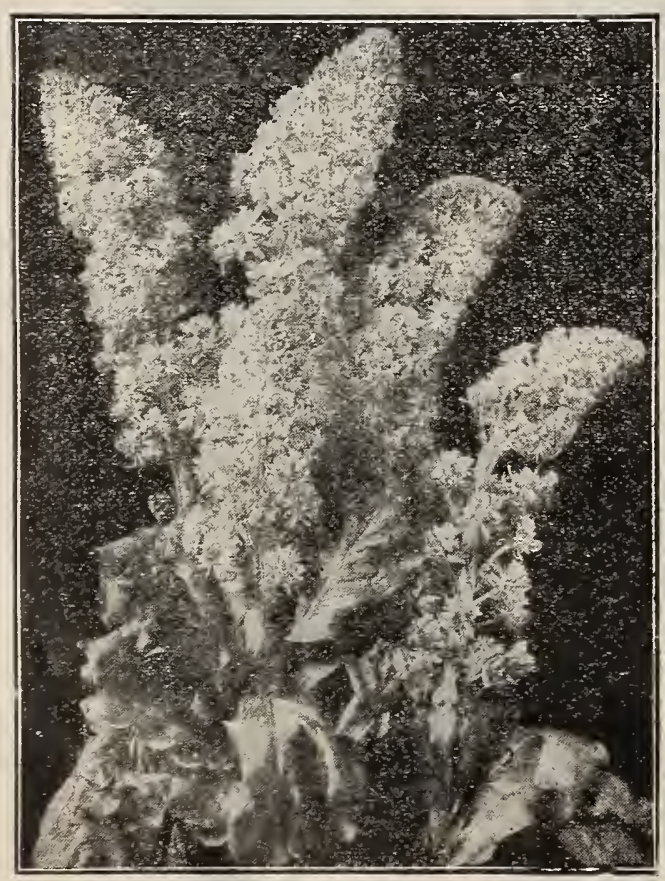

MTGNONFTTE

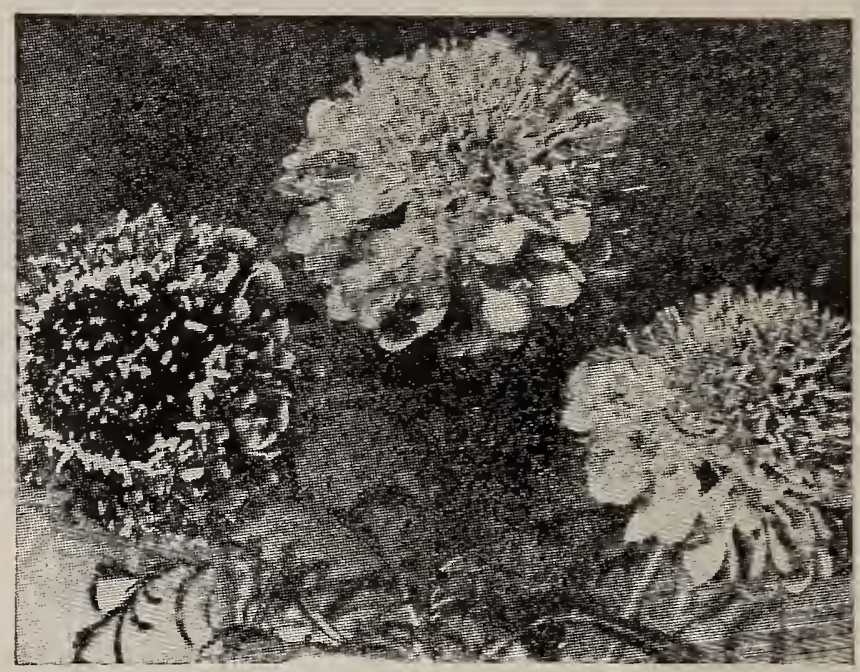

MOURNING BRIDE

ination will take place in about two weeks. After plants are up, transplant outdoors in a sunny situation when danger from frost is past. Tender annual. Pkt., $10 \mathrm{c}$

\section{MORNING GLORY}

Seed is usually sown outdoors early in spring in rows where plants are to remain. Well pulverized soil should be used and the seed covered one-half inch; thin four to six inches apart. If very early blooming is desired, seed may be started indoors and transplanted. Give some support, such as strings or cords, to the vines as soon as they begin to run an dthey will often exceed ten feet in height before the season is over. Hardy annual.

BIUE-Very attractive shade. Pkt.. 10 .

STRIPED-Pkt., 10

WIITH-Pkt., $10 \mathrm{c}$

PURPIE-Pkt., $10 \mathrm{c}$.

CRIMSON-Pkt., 10

MIXED-Many sliaden from white to dark blue, red and striped. I'kt., $10 \mathrm{c}$

AURORA-Flowers decidedly larger and of hearier texture than those of the common Morning Glory; rich, deep blue shading to a white or rosecolored throat, or an exceedingly rich, deep carmine. Very free blooming. Pkt., 10c.

GIANT JAPANESE MIXED-The flowers of this variety are of largest size, often three inches or more across: some are brilliant red or rich blue, others are equally brilliant with broad margins of clear white, some are striped or dotted with blue or red on white or lemon yellow ground, others are clouded with blue and red. Pkt., 10c.

\section{MOURNING BRIDE}

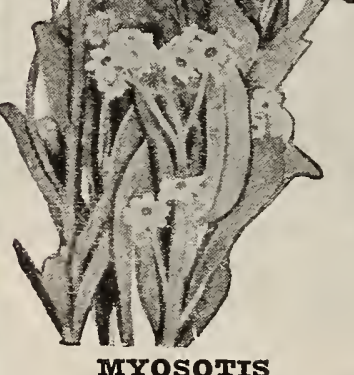

An old-fashioned but most attractive flower. Its great abundance and long succession of richly colored fragrant blossoins on long stems make it one of the most useful decorative plants of the garden. Desirable for cutting as well as for beds and borders. garden. Desirable for cutting as well as for beds and borders. Flower heads about two inches across; flowerets double, surrounda pin cushion.

Seed may be sown in place as soon as ground can be worked; or for earlier blooming sow in hotbed early in spring and trans. plant one and one-half feet apart. Hardy annual; about two to two and one-half feet high.

DOUBIE DART IAROON-A beautiful and attractive variety; flowers dark maroonshaded purple. Pkt., $10 \mathrm{c}$.

DOUBIF WHITE-Especially desirable for mixed bouquets. Pkt., 10c.

DOUBIF MrXFD-Colors include deep and light purple, scarlet, pure white and a dark mulberry, Pkt, 10c.

\section{MYOSOTIS (Forget-Me-Not)}

Old-fashioned favorite and well known to all. The plants produce the delicately blue colored flowers throughout the season and late into fall. For bloom the first year sow early. Give the plants a light winter protection. The Forget-Me-Not is a great favorite in the garden and few of the delicate flowering plants can equal it for beauty. Dainty, elegant little plants with graceful flowers, mostly in shades of blue. Like Pansies and Daisies. they like cool, moist soils, and they will bloom most freely in fall and early spring. MIXFD-Many varieties. Pkt., $10 \mathrm{c}$. 


\section{NASTURTIUMS}

Few plants are more easily grown or remain longer in bloom than the Tropaeolun, witl its large shield-shaped leaves and beautifully irregular flowers, having long spurs and brilliant colored petals. In favorable soil flowers are produced in abundance throughout the season. Much used for window hoxes. If the black aphis appears spray the foliage vigorously with water.

Seed is usually sown outdoors, as soon as the weather is warm and settled, in the row where the plants are to remain. Well pulverized soil, preferably, well drained and moderately rich, should be used, and the seed covered with about one inch of fine soil firmly pressed down. A sunny situation is essential for free blooming. If the soil is very rich the plants give a largo im mount of foliage, but few flowers. For early blooming, start indoors and transplant to the open ground after danger of frost is over.

Tall or Climbing Nasturtiums

MIXED TAII NASTURTIUMS-There is no flower of which you need seed in larger quantities for liberal planting than Tall or Climbing Nasturtiums. For the low price this mixture is very choice. Pkt. $5 \mathrm{c}$; 0z., 15c; 1/4 lb., 30c; 1 lb., $\$ 1.00$.

TAII FRENCA CHAMEIEON-This variety produces blossoms of many distinct colorings upon the same plant. Pkt., 10c; oz., $25 \mathrm{c}$. DARI CRIMSON-Splendid variety; fine foliage. Pkt., 10c; oz. 25c. JUPITER-Giant-flowered. Color a deep, very clear, golden yellow; of the strongest growth; profuse bloomer. Pkt., 10c; oz., $25 \mathrm{c}$.

TAII IING THEODORE-Deep crimson-maroon, so velvety that it is almost black: has dark foliage. One of the best sorts. Pkt.. $10 \mathrm{c} ; 0 \mathrm{z} ., 25 \mathrm{e}$.

TAII PEARI-Nearly white; for contrast. Pkt., 10c; oz., 25 c. REGEIIANUI-Deep purplish violet. Very pretty. Pkt., 10e; oz., $25 \bar{c}$.

SCARIFT-Bright, good foliage. Pkt,, 10c; 0z., $25 \mathrm{c}$.

Tucker's Splendid Mixture of Finest Dwarf Nasturtiums

This is our best mixture of the dwarf varieties. It is composed exclusively of the most elegant, large-flowered sorts, and the brilliantly colored flowers range through every shade and tint known in this favorite annual. This seed will produce a bed or border gorgeous bevond description. Finest mixed. Large pkt. $5 \mathrm{c} ;$ oz., $15 \mathrm{c} ; 1 / 4 \mathrm{lb}$. toc: 1 lb., $\$ 1.25$.

MIXID DWARF NASTURTIUMS-We handle such iarge quan tities of Dwarf Nasturtiums that we are able to offer this especiall choice mixture at a very low price. You should plant this mixture ver liberally. Choice mixed. Pkt., 5c; oz., 15c; 1/4 1b., 30c; $1 \mathrm{lb} ., \$ 1.00^{\circ}$

\section{Dwarf or Tom Thumb Varieties}

GOLDEN KING-Fine yellow flowers. Pkt., 10c; oz., $25 \mathrm{c}$ DWARF CHAMIFIEON-Of brilliant shades and diversified mark ings; some self-colored, others splashed and mottled. Pkt., $10 \mathrm{c}$ $0 \mathrm{z}, 25 \mathrm{c}$

EMPRESS OF INDIA-A rery compact-growing sort, having purplish green leaves; the flowers are fiery crimson. Pkt. 10c; 0z. $25 \mathrm{c}$ KING OF TOM THUMBS-Growing darkest scarlet flowers. Foliage very dark green. A most rich and hrilliant variety. Pkt., 10c;

\section{NICOTANIA}

Hardsome bedding plants of the tobacco family, valuable for long and free blooming. The flowers are salver-shaped, with long tubular corollas.

Sow outdoors when ground is warm and dry or for early bloom-

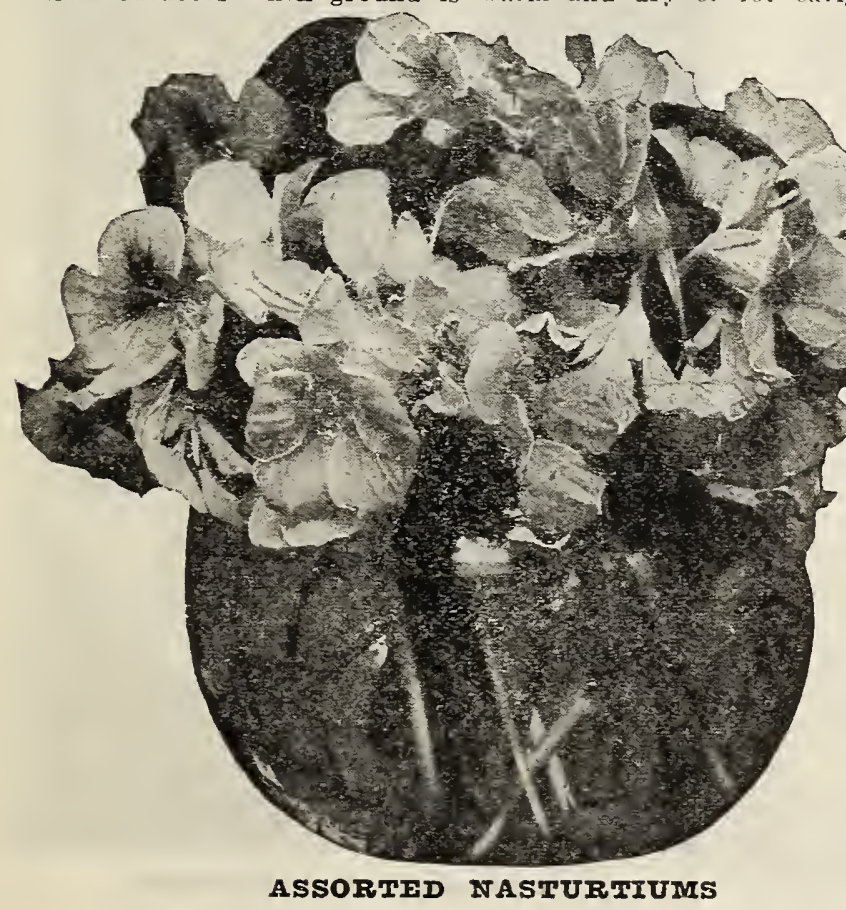

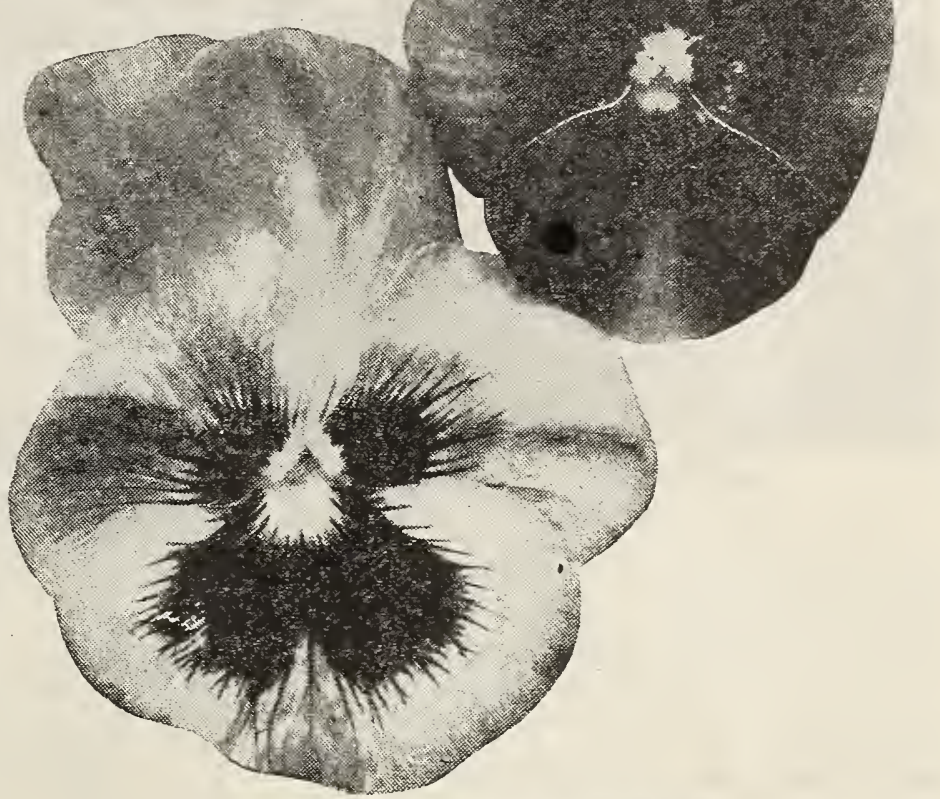

TUCRER'S CHOICF PANSIFS

ing start ir boxes indoors early in spring and transplant to open ground after danger of frost is past. Cover the fine seed inch rleep. Half hardy annuals; about three feet high. AFrINIS-Flowers large, white and fully expanded only in eve aing or cloudy days. Very fragrant. Pkt., 10c.

\section{OXALIS}

Very pretty, spreading herbaceous plants with clover-like leave. and richly colored blossoms. They are especially desirable for hous culture as hanging basket or window plants and are cultivated also in borders and rockeries.

Sow seed in gentle heat in early spring and when well started transplant where they are desired to flower. The plants thrive well in a mixture of loam and sand. They require an abundance of wate during the growing season and should have plenty of sunlight. Half hardy perennial; six to nine inches high.

ROSEA-Rose colored or light purple flowers, star-sliaped, borne in large clusters on long stems. Pkt., 10c.

SANDERAE, MIXED-Flowers white, carmine-rose, or violet, little smalier than Affinis and unlike it, in full bloom during th day. Very floriferous. Pkt., 10c.

\section{PANSIES-TUCKER'S IMPERIAL}

Sow seed in shallow boxes in the house, or preferably in cold fraine where one is available, will produce fine flowers in summer and al through the fall. If the seed is sown in spring outdoors in a partiall shaded location, the seedlings will bloom in autumn.

Pansies thrive best in cool, moist soil, which should be enriched by well-decayed manure or ground bone meal. The flowers will be larger and possess greater substance in their petals. Where extra larg blooms are desired, pinch off all but one or two to the plant.

rUCKER'S CHOICE-Tliese pansies are noted for their almost endless variations, which include striped, blotched, bordered, veined and marbled combinations in every possible color and shade. The plant are of compact growth and flower most profusely and continuously all summer. Pkt., 10c; 6 for $50 \mathrm{c}$.

TUCKER'S IMPERIAI MIXTURFS-This marnificent mixture of mam moth-flowering pansies the blossonis are borne on long stems well above th foliage and distinguished for their gorgeous and varied colorings and beautifu markings of fine substance, velvety texture, perfect form, giant size, frequentl. ineasuring three inches in diameter. The colorings are wonderfully rich and varied; every shade and tint of rose, canary-yellow, black. white, cream, lav ender, garnet, sky-blue and orange are produced in endless variation. Fanc mixture. Pkt., $25 \mathrm{c} ; 5$ pkts., for $\$ 1.00$

TUCKER'S MAMMOTH FANSIES-All our strains are from the most noted seed stocks in the world. and we know they cannot fail to give the mos unbounded satisfaction to amateur and professional growers alike. Sow in the house, hotbed or greenhouse: or as soon as the weather permits the seed may be sown directly in the garden beds. Pkt., 10c: 3 plits. for $25 \mathrm{c}$ 


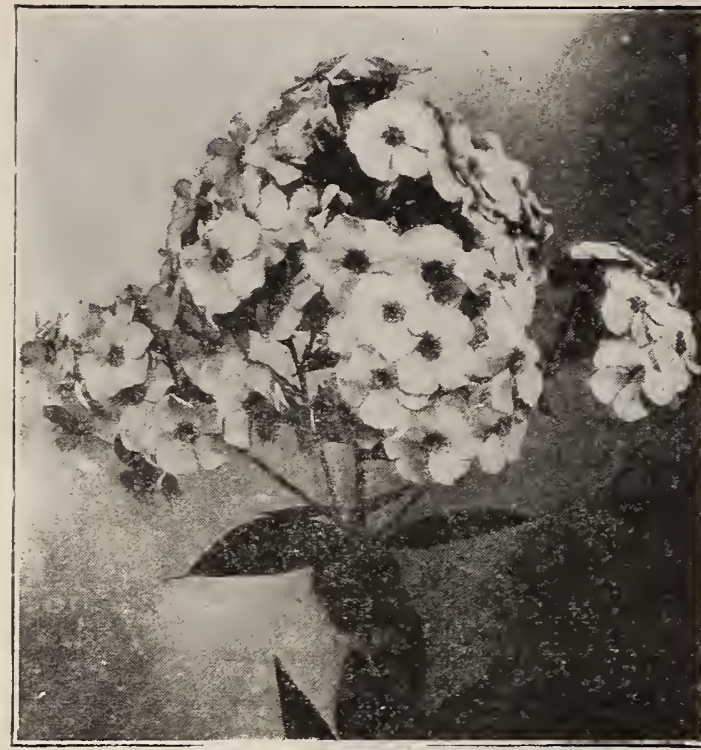

DRUMMONDI PHIOX PETUNIAS

Hardy annuals of the easiest culture. Heat, rain and drought do not affect them. From early summer until late fall the plants are covered with flowers. The named varieties are desirable for pot culture. It is advisable to sow the seeds in doors, covering very lightly, and later transplan to the beds or borders in May. The bedding sorts can be sown in the open ground in May and will be in bloom in a very short time.

COUNTESS OF EIIESMERE - Flowers single, deep rose, with throat, very small. A good bedder. Pkt., 10

NYCTAGINIFLORA-Flowers white, fragrant A good white bedding variety. Pkt., 10c.

FINEST STRIPID AND BLOTCHED-In cludes striped or fine mixed flowers in a wide range of colors. A fine bedder. Pkt., 10c.

FINE MIXED-An excellent variety of markings, including white, stripe

GIANT SINGIE, FRINGED, MIXED-Immense single fringed flowers of finest shades and colors. Pkt., $10 \mathrm{c}$

PHLOX DRUMMONDI (Flame Flower) The annual Phloxes are dazzling in effect particularly so when sown in masses of ribbon beds. The plants grow about one foot high.
By pinching them back while young they become more bushy. The young plants should be set out about one foot apart. Sow in the open ground in May.

PHIOX DRUMMONDI-Mixe

CRIMSON-Pkt., $5 \mathrm{c} ; 1 / 1$ oz., $30 \mathrm{c}$.

PURE WHITE-Pkt., 10c; 1 if oz, $40 \mathrm{c}$

DOUBLE MIXED-Pkt., $10 \mathrm{c}$

IARGE FIOWERING PHIOXES-

This is a magnificent class of these splen-

did annuals. The flowers are large and brilliant in colors.

\section{POPPY}

Well-known plants which will endure considerable hardship and thrive on sandy soil. For permanent beds these flowering hardy Poppies stand unrivaled; the flowers average six inches across, and are grand when in bloom, the plants are robust growers three to four feet high. They do not bloom the first year from seed, but will last for years, improving continualls.

\section{Annual Poppies}

SINGIE POPPIES-Mixed colors. Pkt., SHIRLEY-Delicate colors, in great ra10 cents.

KING EDWARD-Scarlet with l, lack

ADMIRAI-White flower's with broad

scarlet band. Pkt., 10c.

SINGIE RED-Pkt., $10 \mathrm{c}$.

GIAUCUM (TUIIP POPPY)-Mixed dwarf. Pkt., 10

\section{PLATYCODON (Chinese Bell Flower)}

Hardy perennials of easy culture, very rapid growth. Excellent for planting among shrubbery. Blooms all season.

MARIESI-Dwarf Blue Plet, $10 \mathrm{c}$.

GRANDIFIORUM-Steel blue. Pkt., 10c. GRANDIFLORUM ALBUM-White. Pkt., 10c.

\section{PRIMROSE}

Desirable plants for wowing indoors, being in almost constant bloom all winter, nd if transferred to the border will bloom early all summer. Though perennials. new PORTULACA (Rose Moss)

One of the neatest and best of hardy annuals. Specially adapted for dry, light 列

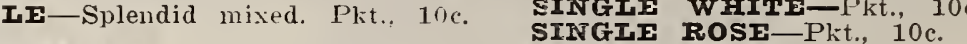

\section{PYRETHRUM (Fererfew)}

Hardy perennials useful in borders. Their daisy-like flowers are fine for cuttin r.

RICINUS (Castor Oil Bean)

One of our best ormamental-leaved annual plants, largely used for the center of

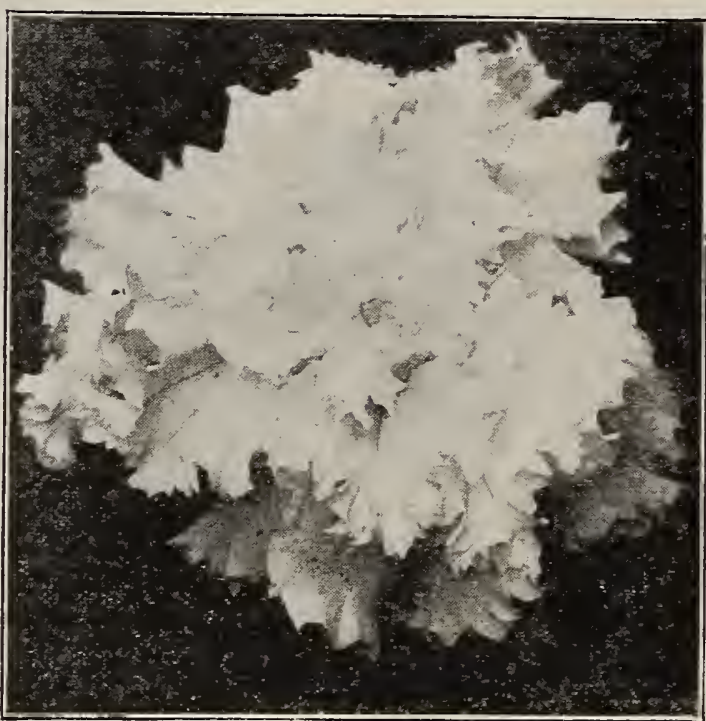

DOUBIE PETUNIA
RICINUS, ZANZIBARIENSIS RICLNe orental plant. Pkt. 10 cents.

PASSIFLORA COERULEA PASSION TLOWER-Ten feet. Fapid growing climber suitable for conservatories;' also for outdoor culture in the summer in the
South. Rich foliage and skr-blue flowers. Pkt., 10c.

PENNISETUM

\section{RUPELLIANUM}

Eighteen inches, ornamental grass used for edgings of Cannas. Plt., 10c.

\section{ROCKET SWEET}

(Hesperis Matronalis)

Produces loose clusters of ilowers, very fragrant during the evening and useful for cutting. Flowers cruciform, somewhat resembling the single Stock but smaller. Seed germinates in open ground if sown after danger from frost. Hardy perennial. Pkt., $10 c$.

ORIENTAL-The large finely formed flowers are a distinct bright orange of is verr brilliant and striking shade. Pikt., $10 \mathrm{c}$.

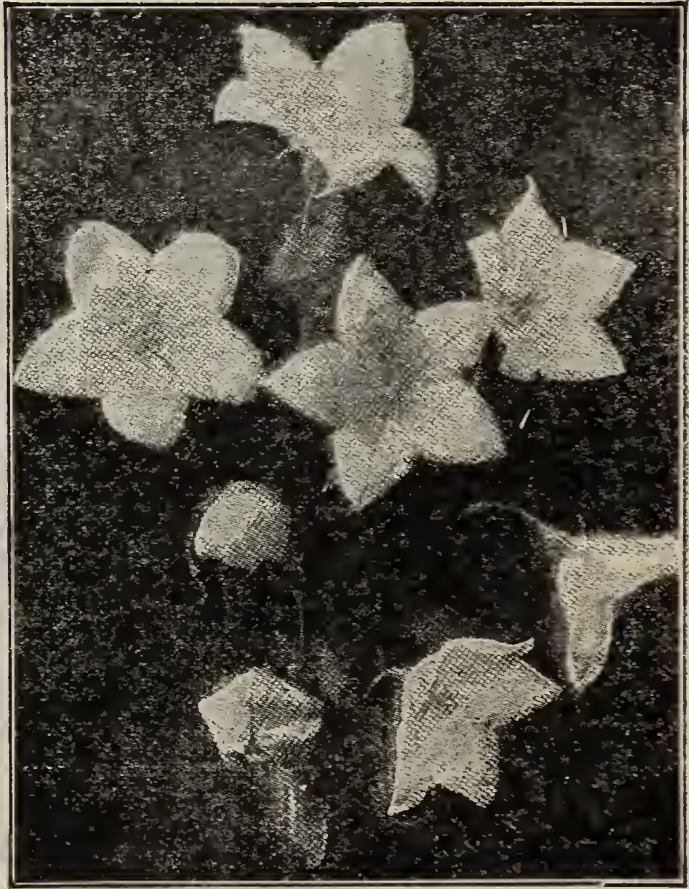

CHINESE BEILTIOWER 
RUDBECKIA (Cone Flower)

Showy, freeblooming; fine for cutting. In bloom from September.

BICOIOR SUPERBA-Large, bright Jellow, with dark spots. Pkt., $10 \mathrm{c}$

PURPUREA-Three feet. Reddish purple flowers, Pkt., 10c.

FUIGIDA VARIABIIIS-Three feet. Orange yellow. Plit. 10c

SALVIA (Flowering Sage)

Among the nost brilliantly colored of garden flowers and ex tremely useful for bedding; also valuable for pot culture and cutting. Blooms are borne in long spikes well above the foliag and are fiery red, crimson or blue, continuing in llower a lons
time. The densely filled flower spikes are often eight to ten inches long and include thirty or more tube-like flowers, one to tw inches in length.

Start early in house and transplant into light soil one or two feet apart; or seed can be sown outdoors after danger from frost is past. Tender perennial, but blooms the first season; height one and one-half to three feet.

SPIENDENS-Sold also as "Splendens Bonfire." The large brilliant scarlet flowers are in striking contrast with the rich, dark green background or dense foliage. This variety is most generally used in parks and on extensive lawns, as it is mor effective bedding plants. Two and one-half to three feet high. Pkt., 10 c

\section{SALPIGLOSSIS}

Very showy bedding or border plants with richly colored, funnel-shaped tlowers wlich are purple, scarlet, crimson, yellow, buff, blue or almost black, beautifully marbled and penciled.

For early blooming seed may be started indoors as early as the middle of March and the young plants set out in the garden one foot apart, or seed may be sown outdoors after settled warm weather. Useful for cutting. Blooms from Angust to October. Half hardy annual; about two feet high.

FINE MIXED-Hybrids. Easily grown, large long stemmed flowers, in many beautiful shades and markings, Pkt., $10 \mathrm{c}$.

\section{SCARLET RUNNER}

A great favorite as an ornamental climber. Brich scarlet sprays of pea-shaped blossoms. Pkt., 10c.

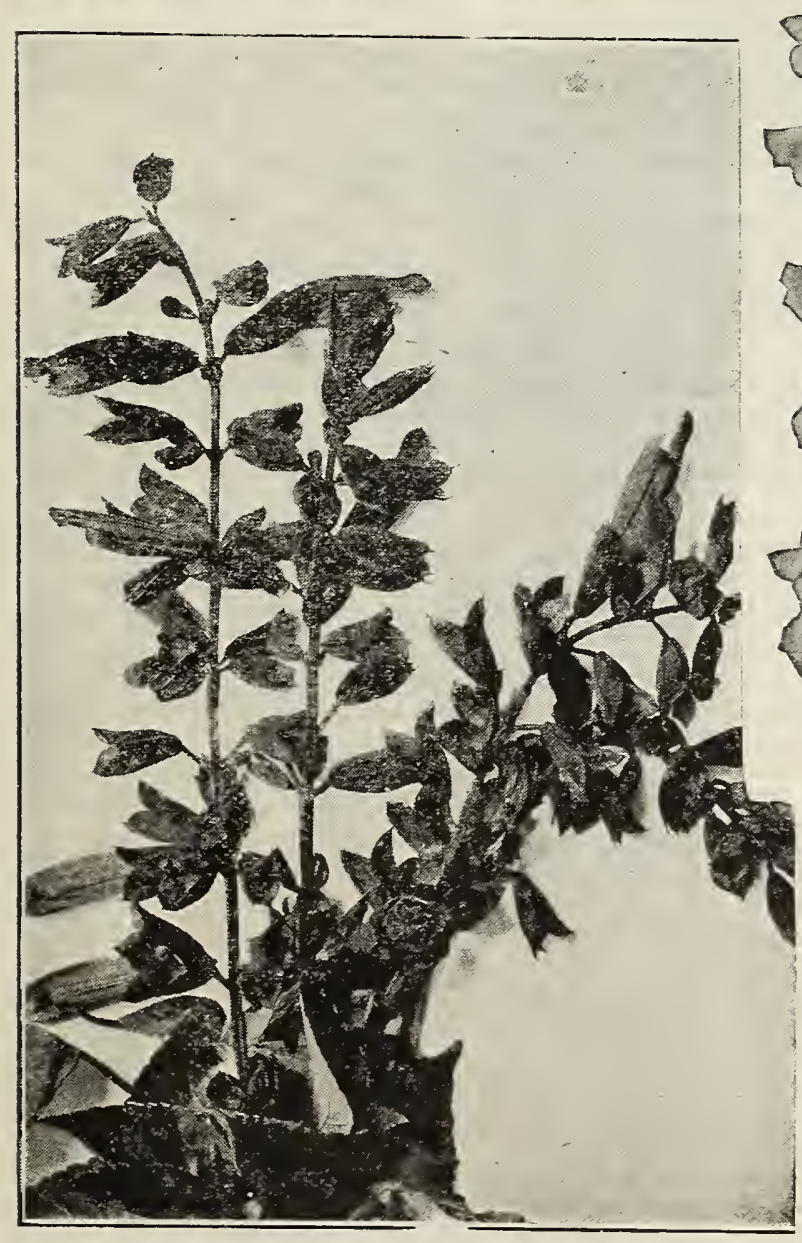

SAIVIA (FIOVIRING SAGI)

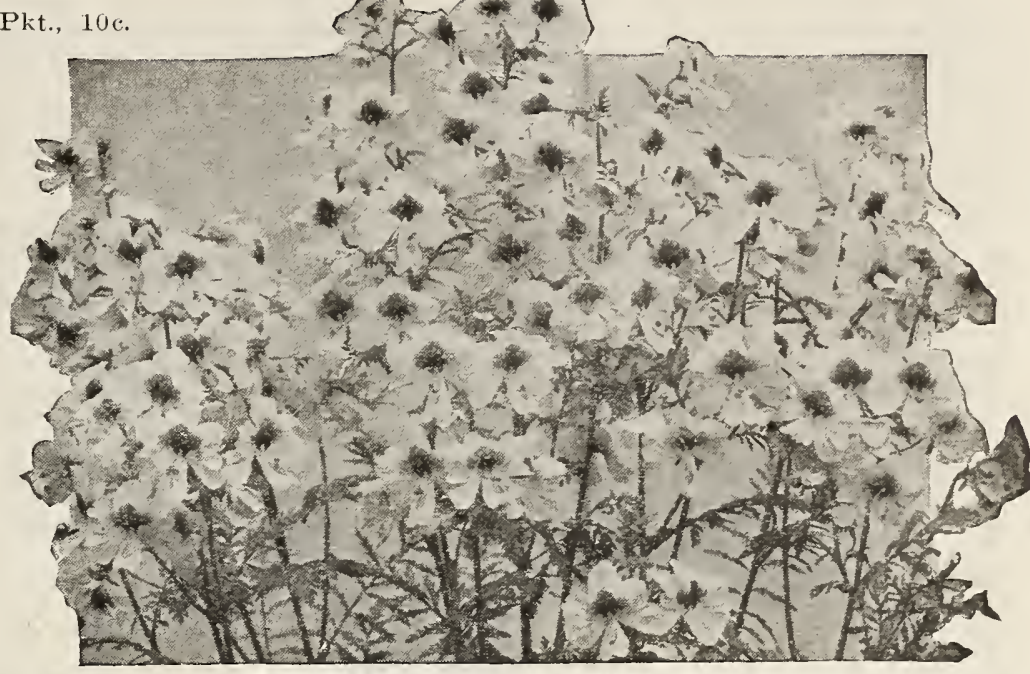

エCPIZANTHUSี (BUTTERTY EUST)

SCHIZANTHUS (Retusus Trimaculatus)

Also known as Butterfly Flower or Poor Man Orchid. Dainty, compact branching plants with finel cut foliage, covered when in bloom with clusters spikes of brilliantly colored butterfly-like flower. Valuable for garden decoration or pot culture. Petal bright yellow with margins and tube of carmine purple-rose, shading from lighter to darker shades. The seed may be sown outdoors after danger frost is past, where the plants are to remain, or star inside and transplant when weather is suitable. Hardy annual; about twenty inches high. Pkt., 10

SMILAX (Myrsiphyllum Asparacoides)

No twining plant in cultivation surpasses this graceful beauty of foliage. The hard texture of its small, glossy green leaves permits the long delicate sprays of foliage to be kept without wilting several dars after being cut.

Planted in spring it makes a fine pot plant for fal and winter. The seed germinates rery slowly. The process may be hastered somewhat by soaking the seeds in hot water for ten hours before planting, bu even then it is often six to eight weeks before the plants make their appearance. Tender verennial climber, ten feet higl,

\section{SNAPDRAGON (Antirrhinum)}

This well-known border and bedding plant of lon blooming season is now one of the best perennial suitable for flowering as an annual. The long, show spikes of curiously shaped tubular flowers with irre ular spreading lobes and finely marked throats a fragrant, as well as brilliantly colored. They a very desirable for cutting.

For blooms the first season outdoors, sow seed rer. early under glass and transplant to open border soon as the ground is warm and dry, in rich, loam soil in a sunny situation, setting one foot apart each way and giving them plenty of water; or sow seed in August or September and cover plants with mulch on approach of cold weather. These fall-sow plants may be the pots and flowed perature, and treatment as gerauiums and carnations. FINE MIXED-Includes all of the best color Pkt., 10e.

STOCKS (Gilliflower) tocks are hardy annual indispensable in every garden mer and winter-blooming varieties. For either bedding or pot culture the aresirabe height of plants,

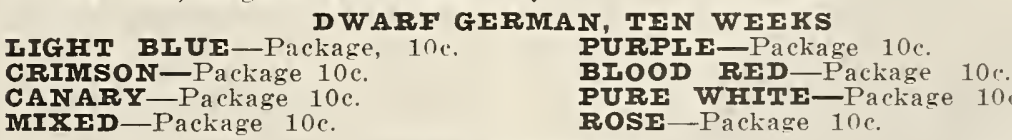

GIANT PERTECTION

Useful for outdoor bedding as well as for pots or cut-flowers. They throw PIN K-Package 15 IIGFT BIUE-Pack PRINC MTXJD-Package 10 


\section{0,WE SELI THE BEST SEEDS THAT GROW ?G?

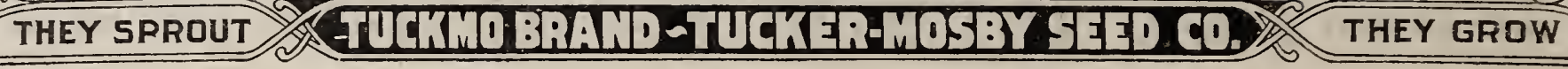

\section{SWEET PEAS}

Culture-Early in spring make a trench three to four inches deep in rich, mellow soil, so arranged that no water can stand in it, and plant the seed in the bottom, covering at first only one inch deep. Sweet Peas, particularly the white seeded sorts, are often a little difficult to start. If the soil is too dry they will remain a long time without germinating; if it is too wet and cold they will not sprout at all. In soils at all heavy, or composed largely of clay, put about one inch of sand in the bottom of the trench and sow the seed on this, covering with more sand. Cover the row with a board to shed the rain and protect the soil from the hot sun, remove this as soon as the young plants appear.

When the plants are two inches high cultivate, and as they grow gradually fill up the trench. When the plants are about five inches high it is desirable to furnish some support for the vines to run upon, preferably a wire netting firmly supported by some support for the vines to run upon, preferably a wire netting firmly supported by
stakes to prevent sagging, but strings or brush are often used with satisfactory results. The blooms should be picked before they form pods or the plants will soon stop flowering.

"TUCKMO MIXTURE" OF SWFET PEAS-This is without doubt one of the grandest mixtures of Sweet Peas ever offered. These we mix ourselves in proper proportion for the most brilliant effect. Price, Pkt. 5c; oz. 10c; $1 / 41 \mathrm{~b} .35 \mathrm{c} ; 1 \mathrm{lb}$., $\$ 1$. SPENCER VARIETIES-This group includes the largest and most beautifully formed Sweet Peas. The Spencers have very large, waved flowers, which are produced abundantly on long, strong stems, making the blossoms most desirable for cutting. Pkt., $5 \mathrm{c}$; oz., $15 \mathrm{c} ; 1 / 1 \mathrm{lb} ., 40 \mathrm{c} ; 1 \mathrm{lb}$., $\$ 1.50$, postpaid.

APPIE BIOSSOM SPFNCFR-Bright rose standard, with wings of very light primrose flushed or tinted rose-carmine. Very large Spencer form. A free flowering sort and a very reliable bicolored sweet pea of robust growth. Pkt., 10c; oz., 25c; $1 / 1$ lb., $75 \mathrm{c}$; $1 \mathrm{~b} ., \$ 2.50$.

ASTA OHN-Suffused lavender or tinted mauve sometimes with pinkish tinge. Spencer form, large and wavy.

AURORA SPFNCER-Flowers brilliant orange-rose, striped and flaked on white. One of the most attractive, very large striped Spencers. Pkt., 10c; oz., $25 \mathrm{c} ; 1 / 41 \mathrm{~b}$., $75 \mathrm{c} ; 1 \mathrm{~b}$., $\$ 2.50$, postpaid.

CONSTANCE OIIVER-Cream ground, beantifully suffused with pale orange-pink, sometimes called bright pink on primrose ground. A large Spencer of vigorous growth, and one of the finest cream pinks. Pkt.. 10e; oz., $25 \mathrm{c} ; \mathrm{I} / 4 \mathrm{lb} ., 75 \mathrm{c} ; 1 \mathrm{~b} ., \$ 2.50$. COUNTESS SPFNCER - Bright clear pink, sometimes darker towards the edges; very large, open form; long stems. The first variety introduced of the spencer type and still the best deep pink sweet pea.
Pkt., 10c; oz., 25e; 1/4 1b., $65 \mathrm{c} ; 1$ Pkt., $10 \mathrm{c}$

DAINTY SPENCER-White suffused and edged with rose-pink; large Spencer form; picote edged; very free blooming. Plkt., $10 \mathrm{c}$; oz., FIFRIDA PFARSON-A very large light pink on white ground, beautifully edged and shaded. Plants sturdy and very vigorous. A most useful pink Spencer for decoration ish pink. Plit., 10c; $1 / 1$ lb..75c;
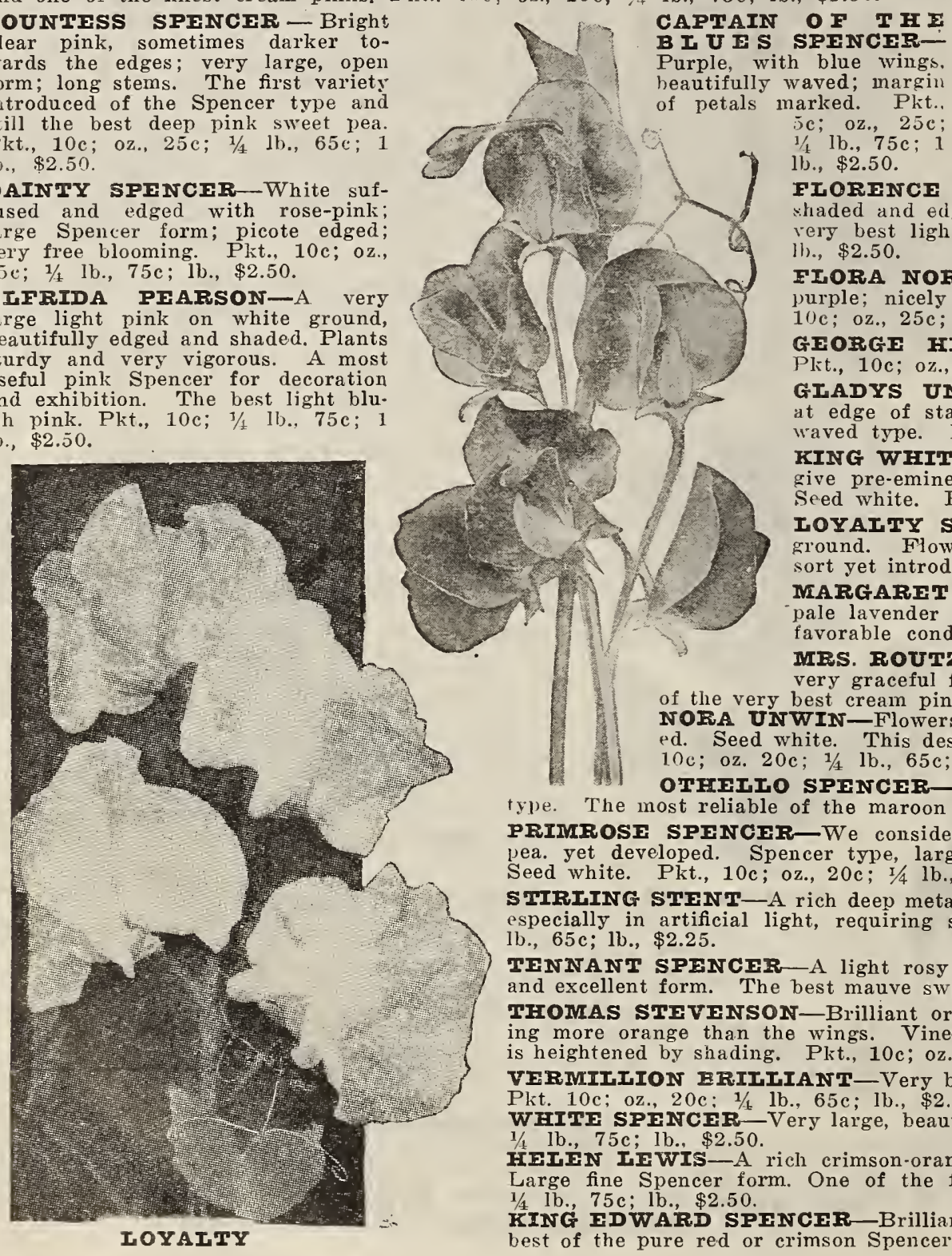
$5 \mathrm{c} ;$ oz., $25 \mathrm{c}$

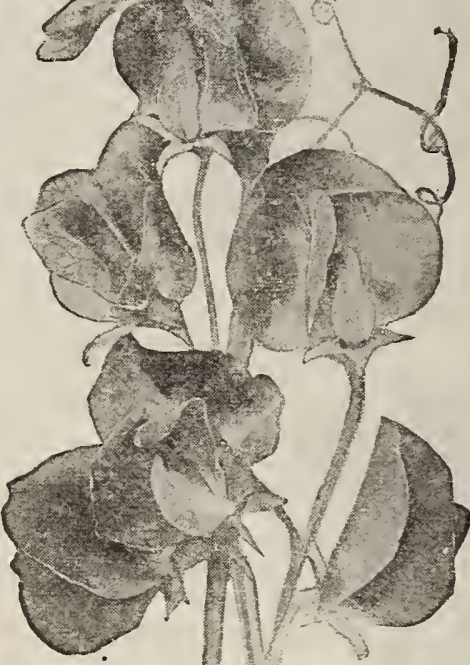
lb., $\$ 2.50$.

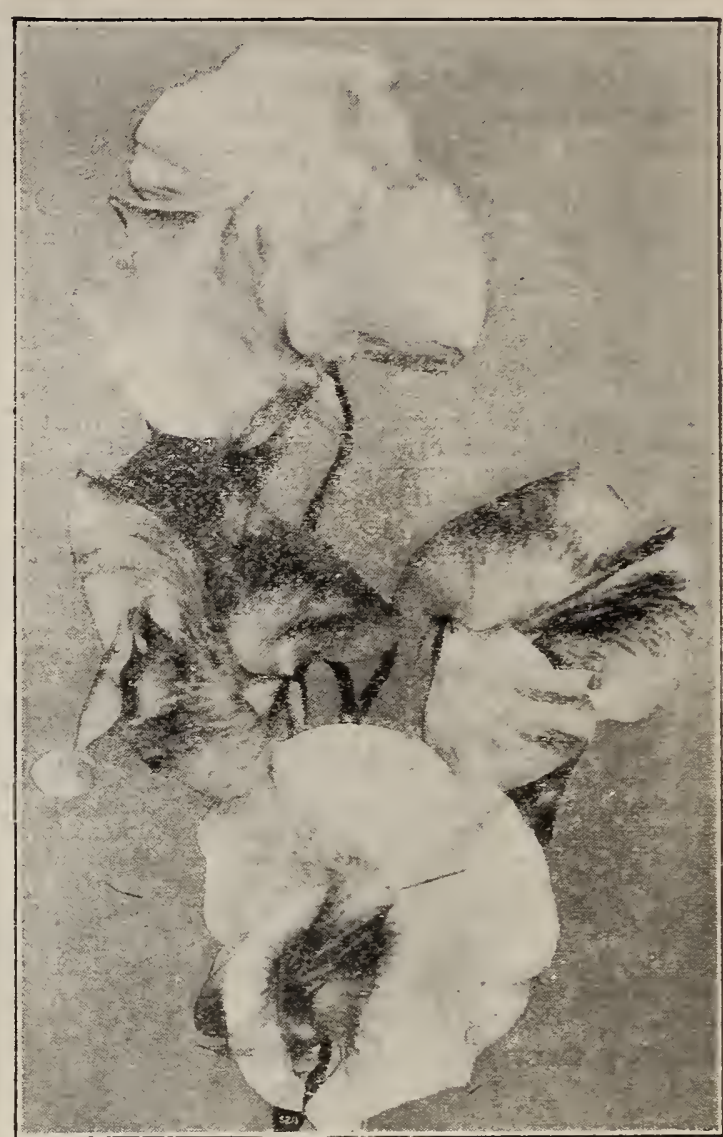

KING WHITr

FLORENCE MORSE SPENCER-A very large, delicate blush shaded and eaged with rose-pink. Excellent for cutting. One of the very best

FIORA NORTON SPFNCrR-Flowers bright blue with tint of purple; nicely waved. One of the rery best blue Spencers. Pkt.. $10 \mathrm{c}$; oz., $25 \mathrm{c} ; 1 / 1 \mathrm{lb} ., 75 \mathrm{c} ; 1 \mathrm{~b} ., \$ 2.50$.

GEORGE FrRBERT-A bright, rose-crimson or rose-carmine. Plit., 10c; 0z., 25c; $1 / 4$ 1b., $65 \mathrm{c}$; 1b., $\$ 2.25$.

GIADYS UNWIN-Clear light bright pink, with deeper shade at edge of standard; texture, heavy. One of the best of the large waved type. Pkt., 10c; 0z., 20c; $1 / 41 \mathrm{~b} ., 65 \mathrm{c} ; 1 \mathrm{~b} ., \$ 2.25$.

KING WHITE-The form, size, vigor, waviness and purity of color give pre-eminence to its claim as the best Spencer yet introduced. Seed white. Pkt., 10c; $1 / 41 \mathrm{~b} ., 65 \mathrm{c}$; 1b., $\$ 2.25$.

IOYAITY SPENCER-Bright blue flaked and striped on white ground. Flowers of large Spencer form. The best blue striped sort yet introduced. Plkt., 10c; oz., $20 \mathrm{c} ; 1 / 1 \mathrm{l}$ lb., $65 \mathrm{c} ; 1 \mathrm{lb} ., \$ 2.25$

MARGARIT MLADISON-A self-colored soft light azure blue or pale lavender Spencer. The form and coloring when grown under favorable conditions are exquisite. Pkt. 10c; oz., 20c; $1 / 4 \mathrm{lb}$, $65 \mathrm{c}$. MRS. ROUTZAFN-A most attractive Spencer of largest size and very graceful form; apricot and buff, shaded light rose at edges. One of the very best cream pink sweet peas. Pkt. 10c; oz. 20c; $1 / 1$ lb. 65c; $1 \mathrm{~b} . \$ 2.25$ NORA UNWIN-Flowers large, of waved type, heavy texture, beautifully frill ed. Seed white. This desirable white sweet pea is practically a Spencer. Plit., $10 \mathrm{c} ;$ oz. $20 \mathrm{c} ; 1 / 4 \mathrm{lb}, 65 \mathrm{c} ; \mathrm{lb}$., $\$ 2.25$.

OTHEIIO SPENCFR-A beautiful, deep, pure maroon of very large Spencer vive. The most reliable of the maroon shades of Spencers. Pkt., 10c; $1 / 41 \mathrm{~b} ., 65 \mathrm{c} ; 1 \mathrm{~b} ., \$ 2.25$. PRIMROSF SPENCER-We consider this the best primrose, or cream and ivory sweet pea. yet developed. Spencer type, large, wavy petals, frilled at edges; clear distinct color. Seed white. Pkt., $10 \mathrm{c}$; oz., $20 \mathrm{c}$; $1 / 4 \mathrm{lb}$., $65 \mathrm{c}$; 1b., $\$ 2.25$.

STIRIING STFNT-A rich deep metallic salmon, suffused with orange. A beautiful Spencer, especially in artificial light, requiring shading to show true color. Pkt., 10c; oz., 20c: 1/1 b., $65 \mathrm{c} ; 1 \mathrm{~b} ., \$ 2.25$.

TENNANT SPENCER-A light rosy pu ple or purplish mauve Spencer of very large size and excellent form. The best mauve sweet jea. Pkt., $10 \mathrm{c}$. oz., $20 \mathrm{c} ; 1 / 1 / 1 \mathrm{~b} ., 65 \mathrm{c} ; 1 \mathrm{~b} ., \$ 2.25$.

THOMAS STFVINSON-Brilliant orange-scarlet of large Spencer form, the standard showing more orange than the wings. Vines vigorous and very floriferous. The intense coloring is heightened by shading. Pkt., 10c; 0z., $20 \mathrm{c} ; 1 / 4 \mathrm{lb}$., $65 \mathrm{c} ; 1 \mathrm{~b} ., \$ 2.25$.

VERMIILION BRIIIIANT-Very brilliant scarlet; large flowering and exceedingly showy Pkt. 10c; oz., 20c; $1 / 4$ lb. 65c; lb., \$2.25.

WHITE SPENCFR-Very large, beautifully waved flowers, pure white. Pkt., 10c; oz.. $25 \mathrm{c}$ :

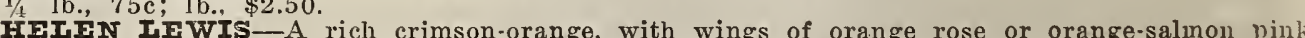
Large fine Spencer form. One of the finest reliable orange sweet peas. Plt. $10 \mathrm{c} ;$ oz.. $25 \mathrm{c}$ : $1 / 10.75 c$. $1 \mathrm{~b}$ KING FDWARD SPENCER-Brilliant crimson-scarlet; very large size and open form. The best of the pure red or crimson Spencers. Pkt., $10 \mathrm{c} ; 07 . .20 \mathrm{c} ; 1 / 4 \mathrm{lb}$., $65 \mathrm{c}$; $1 \mathrm{~b}$., $\$ 2.25$ 


\section{SUNFLOWER (Helianthus)}

A well-known family of hardy annual, very showy plants, large flowers. NEW MINIATURE-Beautiful new hybrids; small single flowers in gieat ahmdance; colors creamy white, lemon and orange. Pkt., $10 \mathrm{c}$

GIOBI OP GOID-Double yellow Howers. Pkt., 10c.

IARGE RUSSIAN-Pkt., 10c.

SWEET WILLIAM (Dianthus Barbatus)

One and one-half feet. For bedding, bordering or cutting this favorite is invaluable. Of vigorous growth and extremely easy culture, bearing fragrant masses of flowers. Blooms second year from seed.

GIANT-FIOWERING MIXID-Pkt, 10c

SINGIE IINEST MIXED-Very popular in old-fashioned gardens. Pkt., 10c. TARENIA

One foot. Good both for bedding out and hanging baskets. Trumpet-shaped flowers; in bloom all summer.

FOURNIERI COMPACTA-Porcelain blue. Pkt., $10 c$

FOURNIERI-Sky blue, violet. Pkt., 10c.

\section{THUMBERGIA}

Useful for window baskets, hangin baskets, vases, etc. Trumpet-shaped flower in great profusion in summer. Mixed colors. Pkt., 10c.

\section{VERBENA}

One of the best annuals for bedding purposes, also for vases and window boxes. Easily grown from seed, producing stronger, more vigorous and better plants than from cuttings. In bloom all summer. Start seed in the early spring, in the house or under glass, and transplant where they are to bloom, after three in the house of growth has been made.

DWARE, MIXID-Pkt., 10c.

CHOICE MIXID-Pkt., 10c.

MAIMMOTH-FIOWTRED VERBENAS-Saved from finest specimens only. Each. per pkt., 15c. Striped, pink, blue, purple, scarlet, white.

\section{VINCA (Periwinkle)}

These very bushy plants with glossy green leaves produce in abundance handsome round or salver shaped single flowers, suitable either for culture in pots or boxes or for summer bedding and borders. If sown early under glass and transplanted in a warm, under glass and transplanted in a warm, no trimming. are in continuous bloom from setting out until frost and are entirely free from the attacks of insects. Mixed. Pkt., $10 \mathrm{c}$.

\section{VIRGINIA STOC}

The plants are of more branching and decidedly more open in habit than the common stock, and are very useful for border or elging. Sow early in spring, or for early blooming sow in fall or start indoors and trans. plant. A continual succession of blossoms may be kept up by sowing at intervals thru spring and summer. Hardy annual; about nine inches high.

RED AND WEITE MIXYD-Clusters of beautiful single cruciforn flowers. Pkt., 10

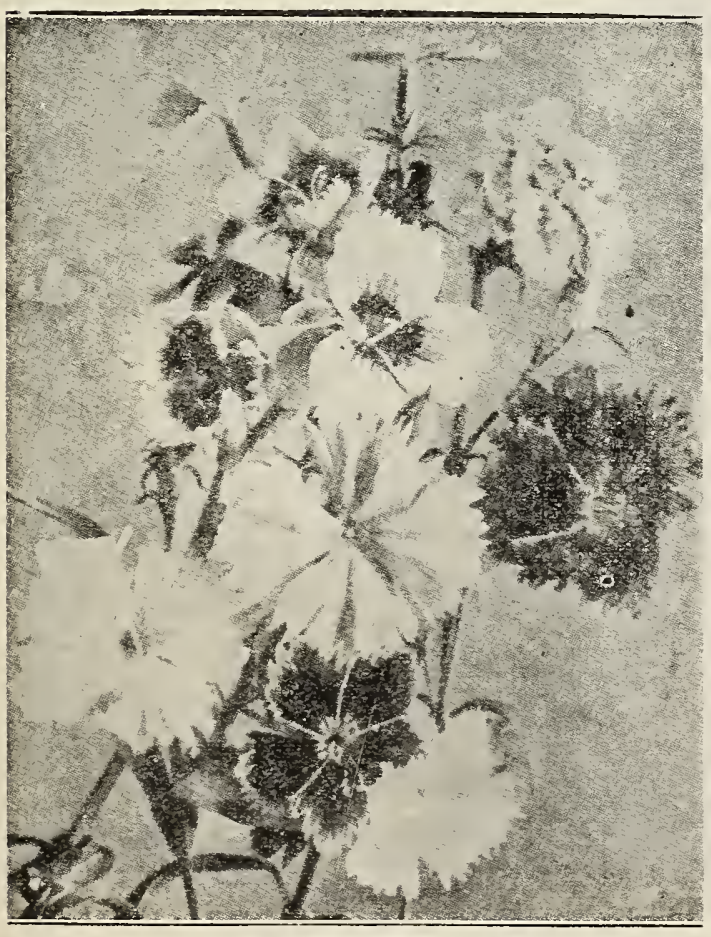

SWEET WIIIIAT

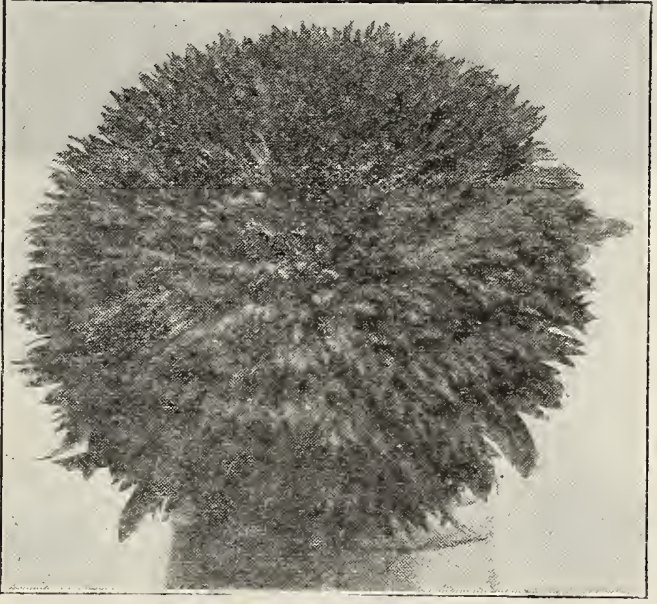

DOUETE SUMFTOW포

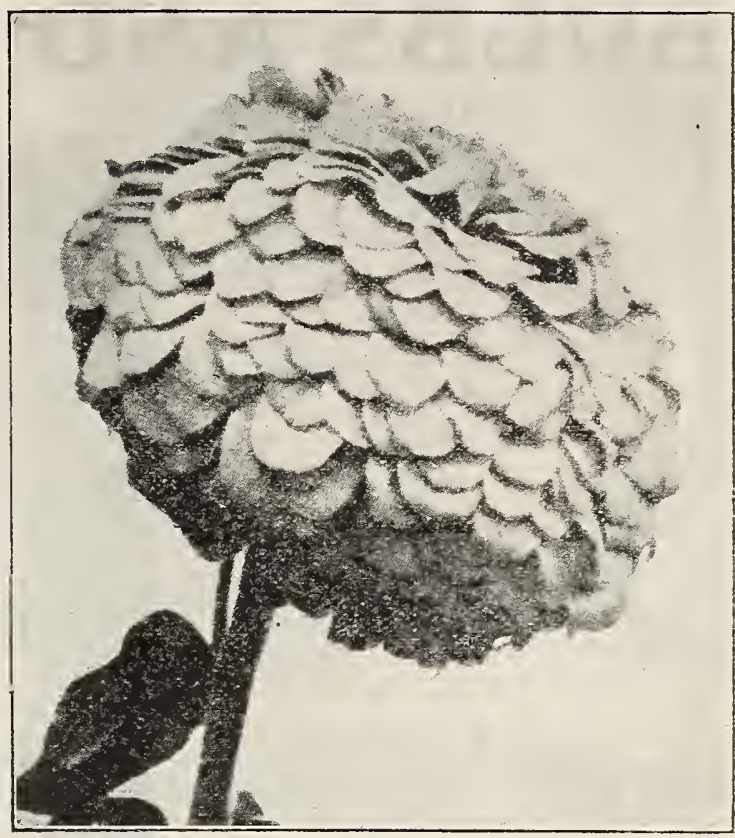

ZINNIA

VIOLETS

Favorite little plants, producing fowers of most delightful fragrance, popular with every one. Sow seed in March or April in beds and transplant. Mixed colors. Sweet rented. Pkt.

\section{WALL FLOWEK}

es of th IVall Flower when properly grown are ver conspicuous in beds and borders ind are rery useful in making bouquets. Sow seeds early in hotbed and while plants are small DOUBIE MIXED-Deliciously fragrant, perfectly double and combine many shades
of color, the orange, purple and chocolate of color, the orange, purple

WILD CUCUMHER

This is a useful climber where a rapid and vigorous growth of vine is desired. To cover or to screen an unsightly building adapted for the purpose. Hardy annual.

WILD FLOWER GARDEN

A mixture of many varieties of beautiful, easy-growing towers producing i con tant and varied bloom the whole season, and is especially suited for those who wish nly a few seeds each of the leading varieties, or a much more extensive collection than their means will permit. In no other manner can so many seeds be obtained for such a small cost. Large pkt., 10c

\section{WISTARIA CHINENSIS}

One of the most beautiful and When well established in good soil it will often grow fifteen to twenty feet auring the season and frequently blooms both in spring and fall. The flowers are very fragrant, single pale blue, pea-shaped and are borne in long, drooping grape-like clusters, often over a foot in length. Foliage light green, pinnate. The seed should be sown in mellow loam early in the spring, or in the greenhouse or hotbed in winter, and when plants are one foot high transplant into permanent positions. Pkt. 10 c.

\section{ZINNIA}

Sometimes called Youth and Old Age. The wellknown bush-like plants of Zinnias produce a pro fusion of large double imbricated flowers, usuall about two inches across, borne on siff stems. The are much used for bedding and are suitable for bor ders and for cutting. Price, per pkt., $10 \mathrm{c}$

DOUBIE YELIOW

DOUEIE DEFP RED

DOUBIE SCARITT

DOUBIE ORANGE

DOUBIE WHITF

DOUBIE STRIPED

DOUBIE BIACI PURPIE DOUBLE DARK CRIMSON

DOUBIE CHOICE MIXID-Includes the a

olors; a very fine mixture.

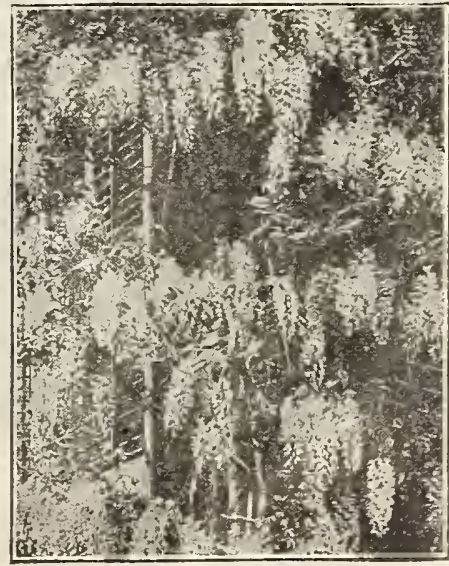

WISTARIA 


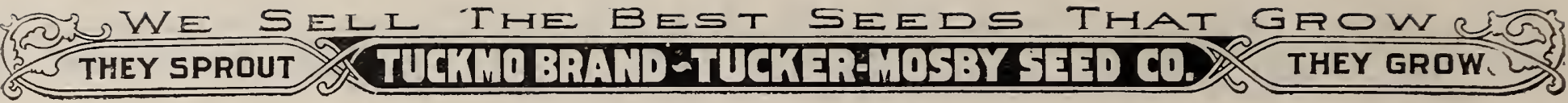 BULBS AND ROOTS FOR SPRING}

\section{DAHLIA}

The roots are tender and easily injured by frost. They should be set out three feet apart, after all danger of frost is over. The best blooms are sometimes obtained if planting is deferred until about June 1. The soil should be deeply dug and well drained, but only moderately enriched with thoroughly rotted barnyard manure. A stiff clay should be avoded. sunny situation is desirable as well as plenty of space and air. Place the roots horizontally, covering two $\mathrm{Ol}^{\circ}$ three inches deep. Give thorough cul. tivation and during dry weather. water once a week. Larger blossoms are usually obtained if most of the side shoots are removed. Dahlias us. aally do not require much fertilizer. and fresh barnyard manure especially should not be used The plants cool cellar, but not allowed to ireeze.

\section{CACTUS DAHLIA}

ROSY MORN-Bright carmine rose tinting lighter

PINT PFATI

QUEEN OF HEARTS-Clear, glistening white petals, deepening to a COMRADE-Yellow, blending to terra cotta; very fine petals, largest size and very good bloomer.

FISA-White, suffused and edgerl EXC马rGIOF-

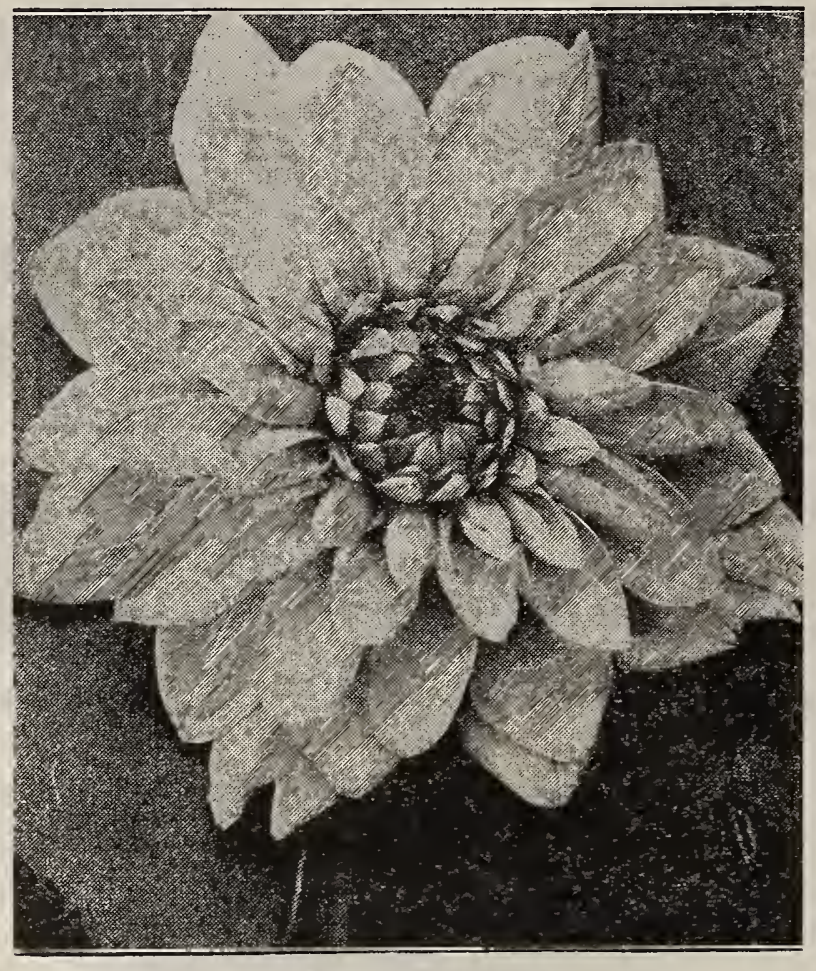

SHOW DAFIIA

PEONY DAHLIA

VARIEGATED IISTZ-A variegation of colors; dark red at the base and gradually shading to bronze. HARRIET WIICOX-Large; delicate creamy white; an early and pro-

IA RIANTA-Large; soft lilac, tinted white; an early and profuse bloomer. crimson, tipped white; center petals white, suffused pink.

JOHN WANAMAKER-This Wolderful new Dahlia is one of the lar: est; the color is an exquisite and fa-t ionalle shade of rose-lake.

DECORATIVE DAHLIA

CRIMSON GIANT-Very large; rich DEIICE-The finest pink decorative Dahlia ever introduced.

JACK ROSE-Color a rich shade ot JUMBO-Deep red, shaded maroon. IYNDFURST-Still the best Scar let Dahlia. Its large, perfectly formed, full-centered Howers are produced MRS. J. GARDNER CASSATT Very large; bright cerise pink.

MINNIE MLCULIOUGH-A super variety. A very soft yellow, overlai MELODY-Color clear canary rellow, tinting to creamy white at the tip. OID GOID-One of the richent of antumn shades; valuable for decorating. Color old gold, shading to orange.

FROF. IMANSFIEID - Very large PFPIF DE PABC-Very flushed pink; an early and profuse bloomer. SYIVIA-Best described as a giant Nymphaea; white in the center, shading to soft pink. YELLOW DURE-Canary on long stems.

DIELTYRA (Bleeding Heart) (Dicentra Spectabilis) A hardy perennial plant, with finely cut foliage, blooming in the spring. Flowers graceful, heart-shaped, pink and white; borne on long racemes. Each, 30c: per dozen, $\$ 3.25$.

\section{TUBEROSE}

PINK SWAN-A silvery pink sort of white swan.

PRINCESS VICTORIA-P Pure canary yellow.

QUEEN VICTORIA-Rich goldien yellow.

If early flowers are cow manure and the rich, sandy soil. Plant.

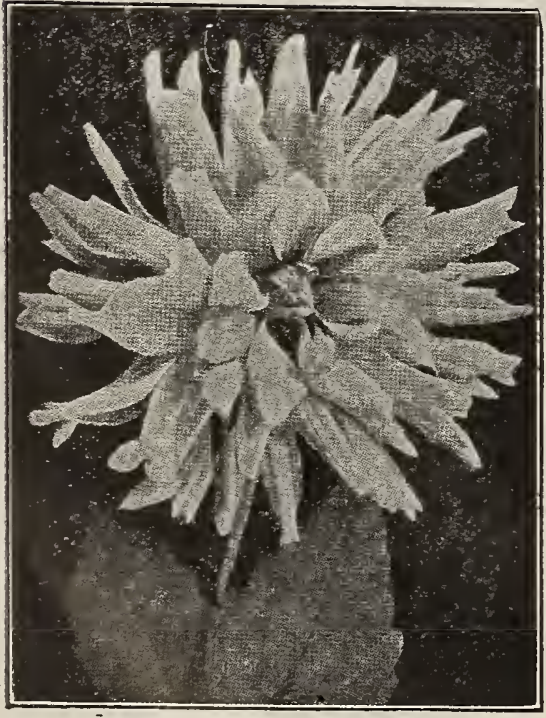

CACTUS DAHIIA the bulbs in this in March or April, water moderatel
and hasten growth by putting in a warm, light place. When weather has become warn, plunge the pots in the earth ont of doors. They will usmally flower before cold weather: if they do not, the pots
brought in and lonlhs will bloom in the house.

DWARF PEARI-Its value over the common variety consists in its flowers being nearly double in size; in:inches to two feet. The fragrance and color same it inches to two feet. The fragrance and color same
common sort. Fach, 10c; doz., $\$ 1.00$, postpaid.

\section{CINNAMION VINE}

dark oreen foliace, and late $m$ the season bearing a profusion of small white flowers odille tubers, much resembling the sweet potato. Each. $25 x ;$ dozen, $\$ 2.50$, potspaid.

\section{MADERIA} Easily and quickly grown, blooms continuously. Well adapted for hanging baskets, pot culture, vases or beds. Flowers are brilliant scarlet, tipped with clear golden yellow. making it most wonderfully attractive Each. 20e; per dozen, \$1.75. postpaid.

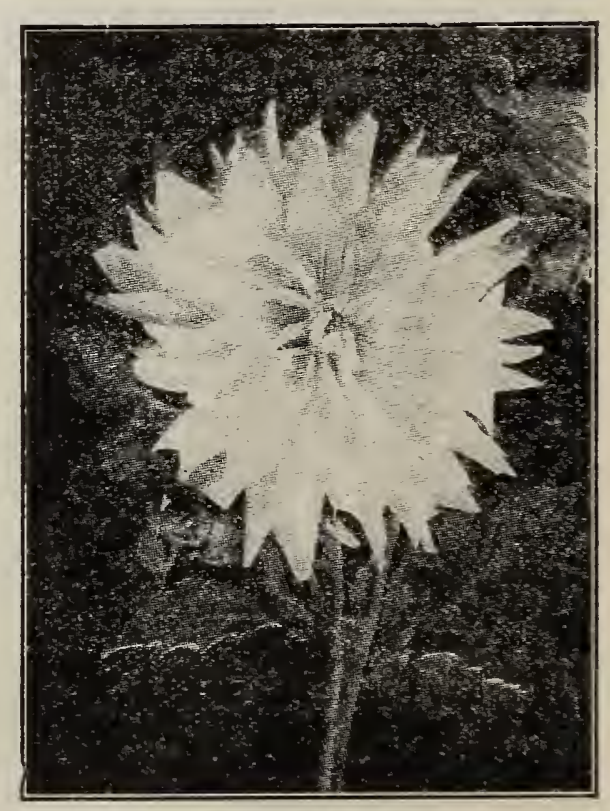

DECORATIVE DAFLIA

On account of the long list of the different named varieties of bulbs of the same character which we are offering and in many instances some of the varieties are very scarce, therefore under the circumstances unless otherwise instructed we will substitute the nearest colored ordered. 
PEONIES (Hardy Herbaceous)

Here is where the Peony has the advantage of most any other flower. Fxempt from any insect pest, hardy as any plant that grows, does not need protection in the winter, comes through all right, and grows stronger and more valuable each year. There are some points that should be observed in planting. Do not plant in low, wet soil. Do not use fresh manure in planting. Any good garden soil is all right. If it is well incorporated with old inanure so much the better. It is best not to have manure come in direct contact with the roots. Do not expect the best results from a Peony the first year after planting, as they have to become established before producing normal flowers. They are hardy, and admirably suited to our Southern elimate, growing in all situations, and even flomishing under trees.

WHIIE, RED, PINK-Each, 35c; dozen, $\$ 3.00$.

Named Varieties

DUCFESS DE NEMOURS-Pure white with shade of snlpliur at collar. Ver large.

GRANDIFIORA ROSEA-Clear pink, good size and free bloomer.

GRANDIFTORA RUBRA-Rich red.

Prices of named varieties.-Each, 50c; per dozen, $\$ 5.00$.

\section{BEGONIA ('Tuberous Rooted)}

The tubers which we offer are of the very best quality and with proper care will give a beautiful display early in the summer. For growing in pots or boxes in the house plam in rich, sandy soil, give good drainage and water freely after the leaves start but do not let the soil become sour or soggy from over-watering. If it is desired to have a hed ontdoors, select a shady, moist situation, making the bed rich with thoroughly rotted manure and leaf mold, if obtainable. Plant as soon as danger from frost is over. After the plant start into vigorous growth keep well watered.

PINK, SCARIET, WHITE, YEIIOW,

MIXED-Each, 20e; dozen, $\$ 2.00$.

\section{GLADIOLUS}

These are among the easiest and most atisfactory bulbs for everybody to grow. As decorative flowers for the garden oi the adornment of interiors, they have few superiors. Start to plant the bulos in April, continuing to do so every ten days or so for success. Set them from two to four inches deep, according to size, and about six inches apart each way. Cut the spikes when the first bloom begins to $\mathrm{mll}$ fold. Place in water and the buds will expand beautifully and last for several days if water is changed daily. Dig the bulbs in the fall and store in place The tuberous roots or bulbs will multiply from year to year.

Price on named varieties, $15 \mathrm{c}$ each; s5c per dozen. Giant Flowering Mixed, 10c each; 60c per dozen.

Choice Named Varieties AMrRICA-The finest pink Gladiolus yet introduced, being especially valuable to florists, both for sale as a cut-flower or use in design work An easy forcer. and money maker for the florist.

NIAGARA - Delicate crean yellow. lightly marked with rosy carmine in the throat.

SCEWABEN-A fine strong growing ri riety, with massive spikes of clear

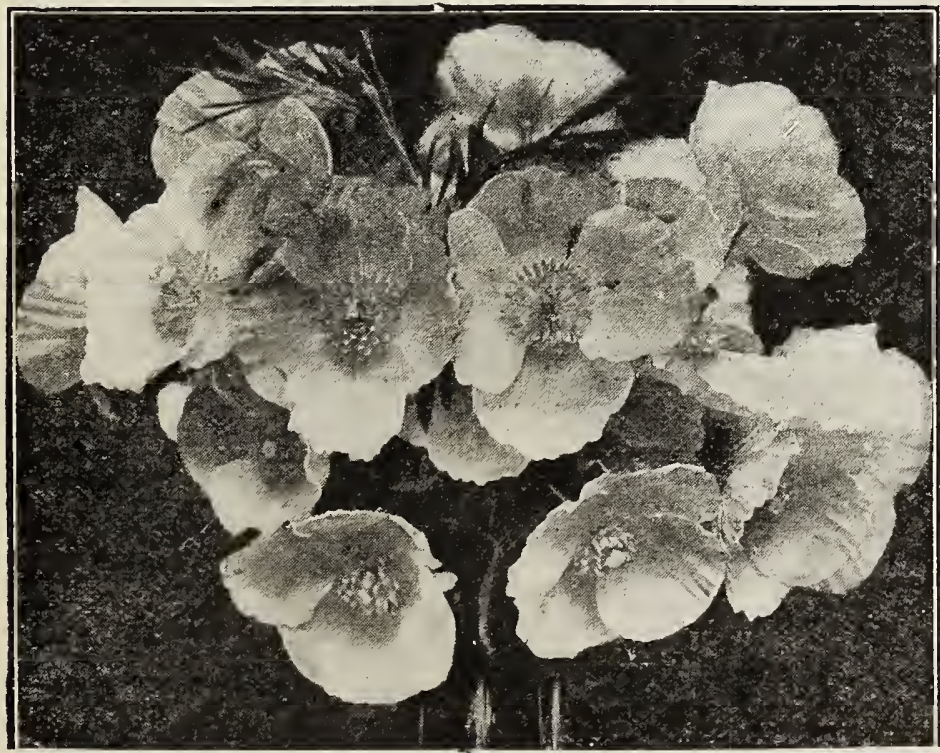

TUBEROUS ROOTED BEGONIAS $25 \mathrm{c}$; dozen, $\$ 2.50$. loc; dozen, $\$ 1.00$.

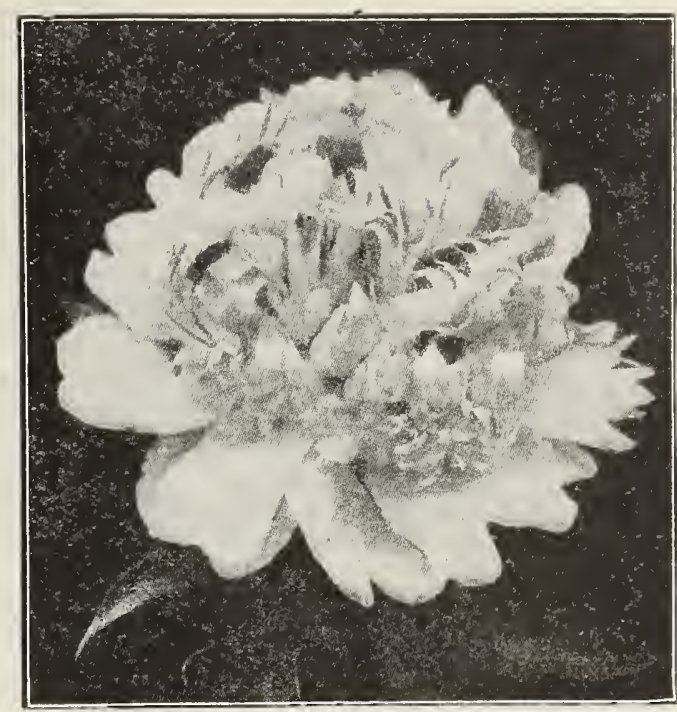

IUCIEST DE NEMOURS

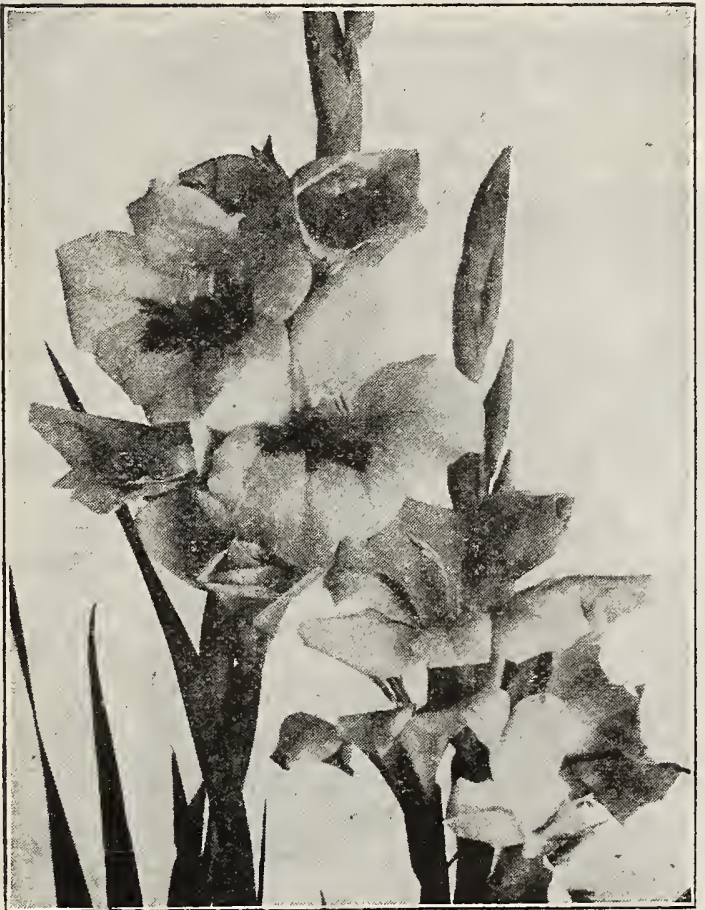

GIADIOIUS
BARON HUIOT-Flowers dar

AUGUSTA_The, best "Florists" Whit rladiolus. Should be planted liberally all. Strong, healthy, long spikes of flowers Healthy bulbs.

CHICAGO WHITE-The flowers ar vell expanded, well placed upon the stalk, yo white with faint lavender streaks in straight stems and from 5 to 7 Howers are open at one time. It is one of the earliest varieties to bloom. hence valuable as a ut-fiower so

HAIIIY-This is one of the earliest of Gladioli. Delicate salmon pink, a pale ground showing at the throat, whichmarked with small red stripes.

MRS. FRANCIS KING - Color is bright "Flamingo" pink, strikingly at ractive. Strong, robust grower and on of the best florists sorts ever introduced. IIRS. FRANK PENDIETON-The "olor is a delicately flushed salmon pink. "olor is a delicately flushed salmon pins ed individually on slender but wiry stem wach thower is strikingly marked with rich maroon blotch on the three lower petal PRIMUIINUS "SUNBEAM" - One of the first varieties of Primulinus blood in America to receive a name. Our intro duction of 1914 . Its strong growth and clear yellow color ma

\section{CALADIUM}

Known also as Elephant's Ear. This is one of the finest tropical plants which can be grown in the open air in the north. It can be made to produce three to ten leaves three to four feet long and nearly as wide, on stalks four to six feet high. The soil best suited to Caladiums is a mixture of fibrous loam, leaf mold, peat, and well rotted cow or sheep manure in equal parts, with a sprinkling of sand added. Bulbs may be planted outdoors as soon as danger of frost is over, covering about three inches deep; or for largest growth start early, indoors in pots and set out when the weather is warm and settled. But little water must be given to the roots till active growth commences when, as the plants develop, they require an abundance. Humidity and warmth are necessary for their best development.

FIRST SIZF BUIBS-Nine inches and over in circumerence. Nach,

SECOND SIZE BUIBS

Each, 15c; dozen, \$1.E.0.

THIRD SIZE BUTBS-Under seren inclies in circumference. Each, 


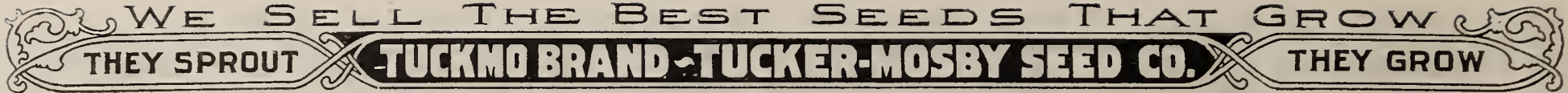

No tlowers are more expressive of the idea of queenly beauty and faultess purit an the Lily.

Bulbs should be planted as soon as the frost is out of the ground; the earlier the

etter. Select a well-drained spot, dig the soil deep and make it fine, enriching it bundantly with well rotted cow manure, adding a liberal mixture of sand. Set th bulbs from three to five inches deep according to size. During the winter it is advisable to cover the surface of the bed with a thin layer of manure, which will afford a slight protection to the bulbs and also materially enrich the soil. In the spring the manure may be removed or dug in between the rows. Care should be taken that they have proper drainage, no water being allowed to stand around the roots. Once firml 作 extra fine specimens, plant bulbs in pots early in spring and grow them in the house or under glass.

AURATUM (GOID-BANDED IILY OF JAPAN)-This favorite garden Lily is white. Height outdoors, in the open, usually three to five feet. Each 50c; doz., $\$ 4.00$ SPECIOSUM RUBRUM (ROSFUM)-The Speciosum or Lancifolium are amon most charming and brilliantly beautiful of the Japanese Lilies. The six broad, white or pink petals are thickly dotted with rose or crimson spots. Especially thrift and hardy. One of the best for garden culture. Height two to four feet. Each 40 c: $\$ 3.50$ per dozen.

TRIGINUM SPIFNDENS (IMIROVID SINGIE TIGER IIIY)-This is of most striking appearance with vert large, nodding flowers of excellent form; color, orange-salmon with dark spots. The plants are of a more robust habit, with longe lower spikes than the older type and are highly recommended. Height outdoors in the open usually three to four feet, sometimes taller. $40 \mathrm{c}$ each; dozen, $\$ 3.50$.

IIIY OF IfFE VAIIfY-A well-known and universally admired spring flowering plant, bearing bell-shaped freely producing and powerfully fragrant flowers. To grow open ground, select a partly shaded, rather moist situation, and they are charmin when grown in large patches, as their handsome green leaves and lovely sprays of flowers make a beautiful effect together. When once planted and established the crowns increase in numbers and the large ones flower each rear without attention. express (only), clumps, each 50c; dozen, $\$ 5.00$

SPECIOSUM ATBUIM-Pure whit

Howers with a greenish band through the center of each petal: of great
substance, very fragrant. One of the best for general culture. Height of plants in the open usually two
four feet. $40 \mathrm{c}$ each; dozen. $\$ 3.50$. TIGRINUM FIORE PIEIN (DOUBIE TIGER IIIY)-Thi magnificent lily

bearing tems; color, bright orange-red spotwith black. Height

$10 \mathrm{c}$ each; dozen, $\$ 3.5$

CANDIDUM (ST. JOEEPH'S OR ANNUNCIATION IITY)-EAcl,

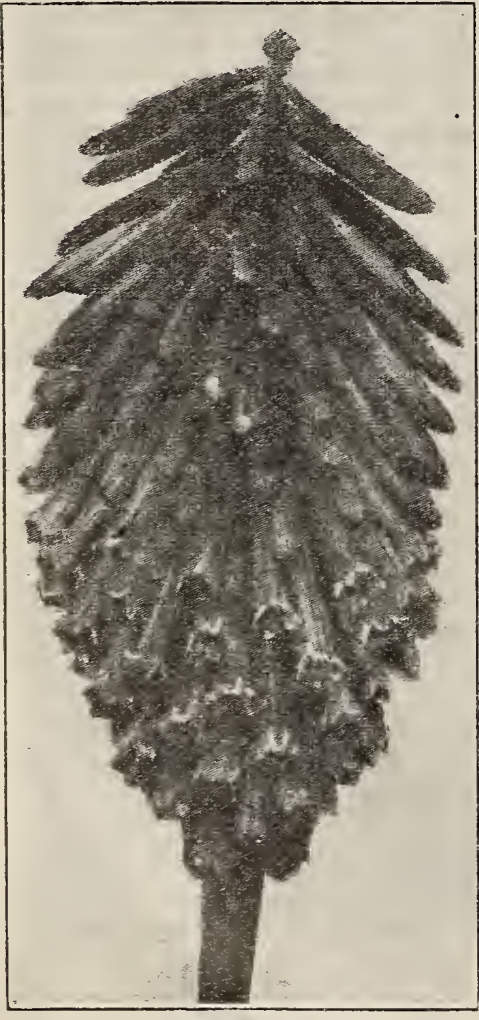

TRITOIMA

\section{LILIES}

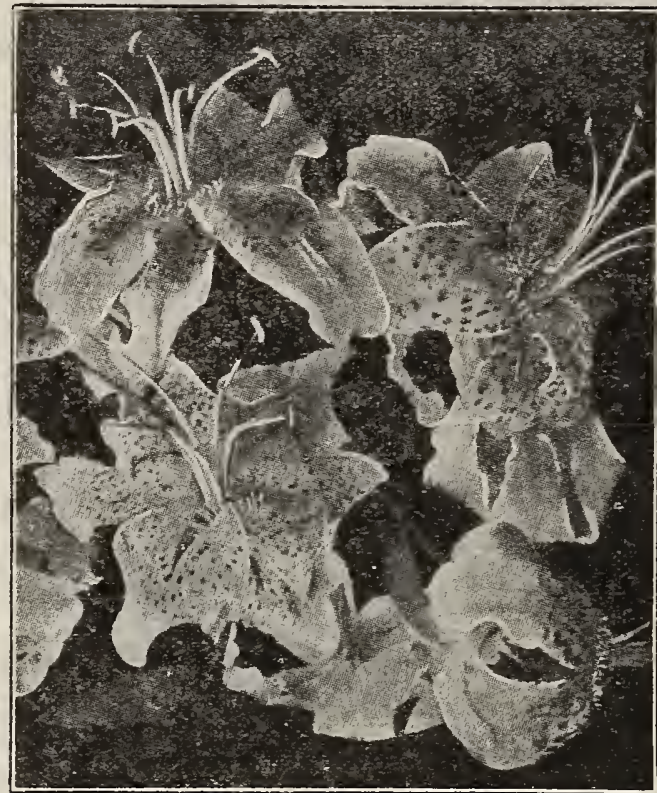

SPECIOSUM RUBRUM

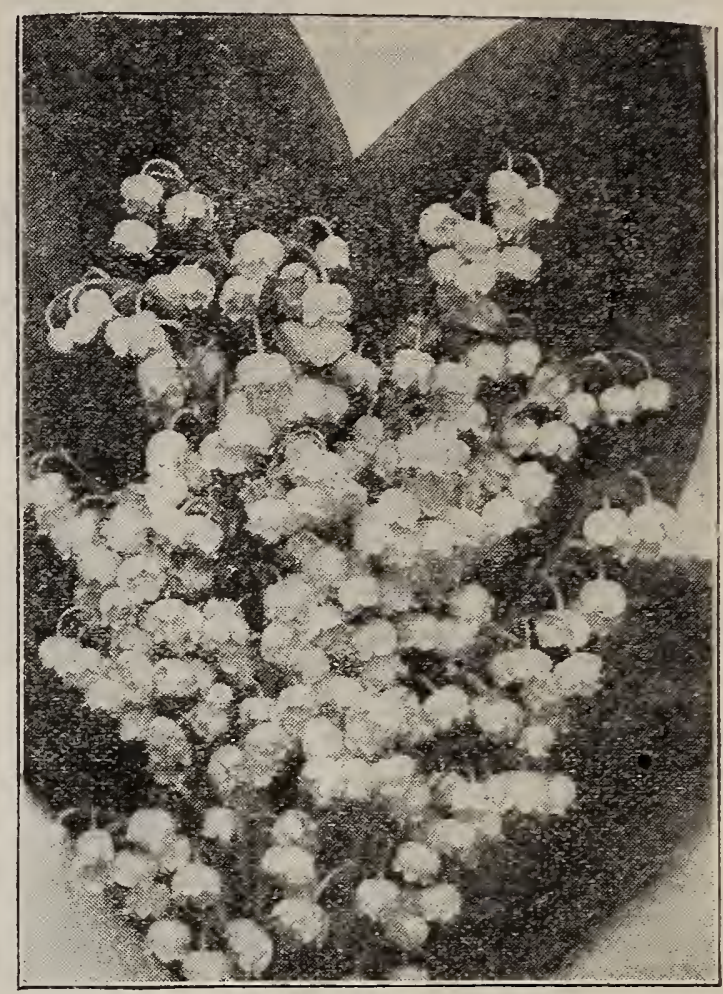

IIIY OF TFE $\nabla A I I F Y$ AMARYLLIS

Most of those we list are suitable for house conervatory and garden Halli is an outdoor, hardy sort. For pot culture Amarpllis require a welldrained, turfy, sandy soil and a growing and resting season.

ATAMASCO AIBA (White Fairy Lily)-Plan three or four bulbs to a five-inch pot. For the garden culture set out in spring and lift in autumn like Gladiolus. Each, 15c; dozen, $\$ 1.50$.

FORMOSSISSIMA (Jacobean Lily)-Rich, deepvelvety crimson flowers which usually appear in ad vance of leaves. Each, $15 \mathrm{c} ; 2$ for $25 \mathrm{c}$; doz., $\$ 1.25$. ATAMASCO ROSEA (Fairy Lily)-In bloom al summer. Fine for edging. Rose pink flowers. Each, $15 \mathrm{c}$; dozen, $\$ 1.25$.

HAIII (Lycoris squamigera) - A hardy variety suitable for shrubbery borders. The green leaves pro. duced in early spring disappear in June; in August the rosy-lilac flowers appear. Each, 25c;5 for $\$ 100$. JOFNSONI (Barbadoes Spice Lily) - Large trumpet-shaped flowers, with a white stripe through each
petal. Large selected bulbs, each, $35 \mathrm{c} ; 3$ for $\$ 1.00$. TRITOMA

TRITOMA (PFITZERI)-An improved variety o the plant sometimes called Red Hot Poker. Th handsome flowers are produced in large spikes of rich orange-red tinted flower tubes. Plant two feet apart. Tritomas are hardy south of Cincinnati, when well covered in winter. In the north, dig up the plants in November, place in boxes with dry earth and store in a cellar. In spring place in a warn sheltered, well-drained spot, preferably with a background of shrubbery. Each 25c; doz. \$2.50, postpaid.

\section{GLORIOUS CANNAS}

fine foliage plant. A rapid grower, producing large trusses of beautiful flowers from early summer to late in the autumn. Prices, $15 \mathrm{c}$ each; dozen, $\$ 1.50$, postpaid.

BUTTER CUP-Beautiful clear yellow flower. GOIDBIRD-4 $1 / 2$ ft. Bright yellow flowers, good size and shapa.

GUSTAVE GOMPPER- $31 / 2$ to $4 \mathrm{ft}$. Flowers of great size and substance, in color, a fine golden with red. Stiff erect stems and la rge flower spikes. IOUISIANA-6 ft. Very large beautiful vivir scarlet orchid-like flowers, often measuring 5 to 6 inches across. Foliage a glossy green.

MRS. AIFRED CONARD-4 ft. Green foliage Flowers salmon pink of large size on finely shaped flower heads.

MAROS -3 ft. Free bloomer, pure white flowers. DAVID IARUM-3 $1 / 2$ ft. Dark bronze foliage. Strong grower and one of the freest blooming

EUREKA-4 ft. The best white for massing, a robust grower making sturdy, shapely plants.

HUNGARIA-Very compact, almost dwarf and never hurns. Trusses of enormous size, borne well above the foliage. Flowers very large, with very large petals. Color purest La France-pink, with satin sheen.

YEILOW KING HUMBERT-An orchid-flowering sort of the well-known variety King Hum bert Has the same habit of growth as its parent; foliage a very dark green. with flowers meas uring 5 to 7 in. across; individual petals 3 to $31 / 2$ in. in diameter. Color of flower a deep rich vellow, softly spotted and blotched with bright red. KING HUMBERT-It is a cross between the orchid-flowering and the Frellch or Crozy type. combining the best features of both, the large flowers of one with the free-blooming character of the other, and the handsome broad, tropica foliage.

AMERICA-Flowers extra size, dark yellow, veined with red.

CHAS. HINDERSON-Deep rich erimson

MIXID RID SFADES-All best colors. 


\section{ROSES}

All our roses are two-vear-old field grown, and have bloomed in the nursery one season. Do not confuse our plants grown in open air with small greenhouse stock. A Rose does not bloom on old wood; hence the stronger growth of new wood each year, the more blooms you will get. After planting each branch should be cut back, leaving the plant with two or three branches, each with four to six eyes or buds. All roses should be cut back except climbers and these require very little pruning. The best time for the pruning process is in January or February just before the sap begins to start.

In order to grow our roses successfully an open spot should be selected, where they will get plenty of light. If the soil is poor, remove it to the depth of a foot or eighteen inches, and replace it with a mixture made of three parts loamy soil and one part manurethoroughly mixed. If the soil is good a little manure well worked in will prove of benefit. The fall is probably the better time to plant hybrid roses; they should be set deep, and a covering given them of autumn leaves to the depth of six inches to a foot. A few evergreen boughs will hold these in place. In the spring the leaves will be considerably beaten down with rain and snow; dig them into the

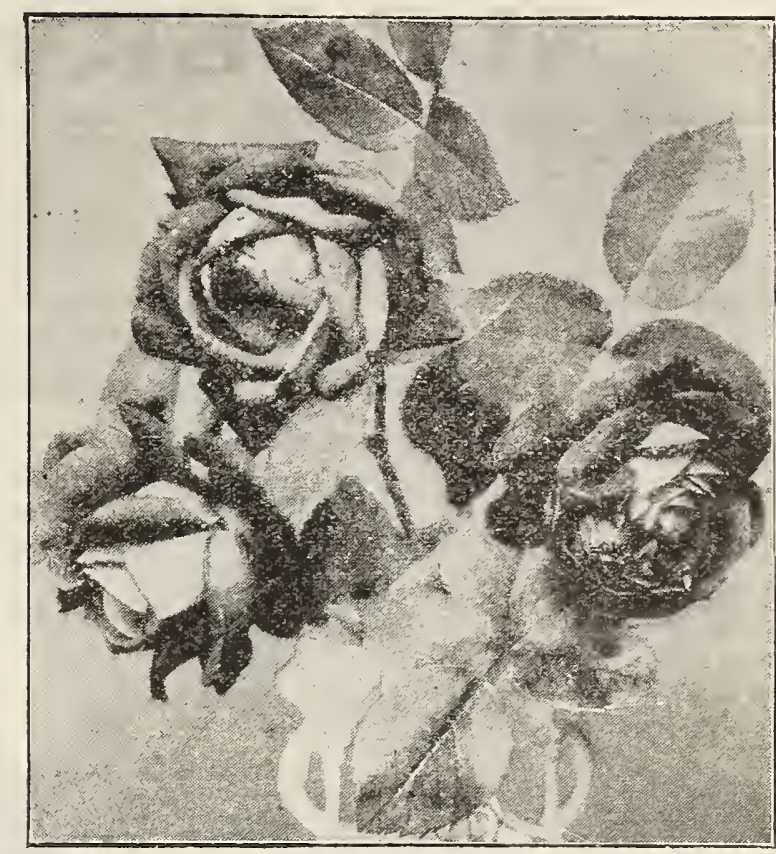

RADIANCI ground and cut back the roses, and with the new growth you will have a magnificent display.

The Queen of Flowers should be planted more extensively in all districts. The city and town is not the only locality where the Rose should find a place. At a very little outlay, the lawn in front of the farm house can be greatly embellished by the artistic arrangement of a bed of roses. ANTOINE REVOIRE-Creamy white with fine pink tint. Each, $\$ 1.25 ; 10$ for $\$ 11.50$.

BETTY-Golden yellow, very fragrant. Each $\$ 1.00$ 10 for $\$ 9.50$.

COJUMRIA-True pirk of unusual size. Each. $\$ 1.00 ; 10$ for $\$ 9.50$.

GEORGE ARRENDS-Brilliant pink. Each, $\$ 1.00$ 10 for $\$ 9.50$.

JONXBYIER-Bright cherry red with inside petals silvery white. Each $\$ 1.00 ; 10$ for $\$ 9.50$

REINE MARIE HENRIETTE-Climber, free bloomer, brilliant crimson. Wach $\$ 1.00 ; 10$ for $\$ 9.50$. UIRICH BRUNNER-Cherry-red, large and fine. Each, $\$ 1.00 ; 10$ for $\$ 9.50$.

AMERICAN BEAUTY-Probably the best k1

perfection under glass, but is desired always for the rarden culture. Each, $\$ 1.25 ; 10$ for $\$ 11.50$.

BABY RAMBIER-A dwarf crimson rambler that is perfectly hardy and produces small blooms from early June until frost. Each. $\$ 1.00 ; 10$ for $\$ 9.50$

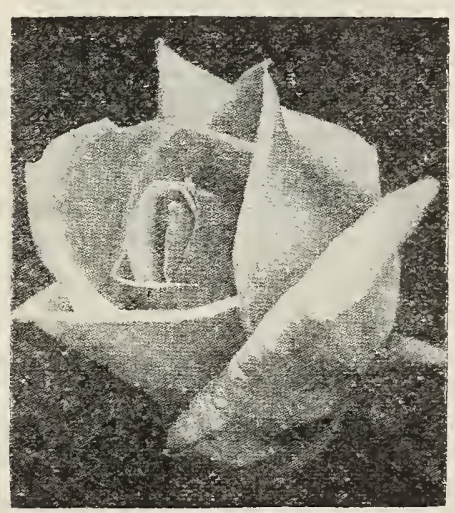

SUNBURST

GRUSS AN TEPIITZ-Climber. A wonderful rose from China. Rich, brilliant crimson; one of the freest bloomers. Stands by itself; distin
roses. Each, $\$ 1.00 ; 10$ for $\$ 9.50$.

IKAISERIN AUGUSTA VICTORIA-T. Beautifully formed blooms of pure white with a touch of lemon shading in center. A grand rose. Free and constant bloomer. Each. $\$ 1.00 ; 10$ for $\$ 9.50$.

DOROTHY PERTINS-A strong climber with exquisite shell pink flowers. Each, $\$ 1.25 ; 10$ for $\$ 11.50$ ETOIIE DE FRANCE-One of the best red crim son varieties; very fragrant and flowers are large. Each, $\$ 1.00 ; 10$ for $\$ 9.50$.

FXCEISA-Same color as Crimson Rambler; fine.

healthy foliage. Each, $\$ 1.25 ; 10$ for $\$ 11.50$. Beauty or Snow Queen. Strong grower, clear white. unusually large blooms. Each, $\$ 1.00 ; 10$ for $\$ 9.5$ RADIANCE-H. T. Brilliant rosy carmine. Fint
in form and flower. Large bloom; petals are cupped. in form and flower. Large bloom; petals
Very fragrant. $\$ 1.00$ each; 10 for $\$ 9.50$.

CIIMBING AMERICAN BEAUTY-Same color, size and fra- RED RADIANCE-H. T. Sets its very large crimson-scarlet bloom grance as Ameriean Beauty, but a climber. Sets a mass of bloom on strong heavy canes. Growing in favor every season. $\$ 1.00$ each. in the early summer and fall. For outdoor culture we prefer it to the old Anerican Beauty. Each, $\$ 1.25 ; 10$ for $\$ 11.50$.

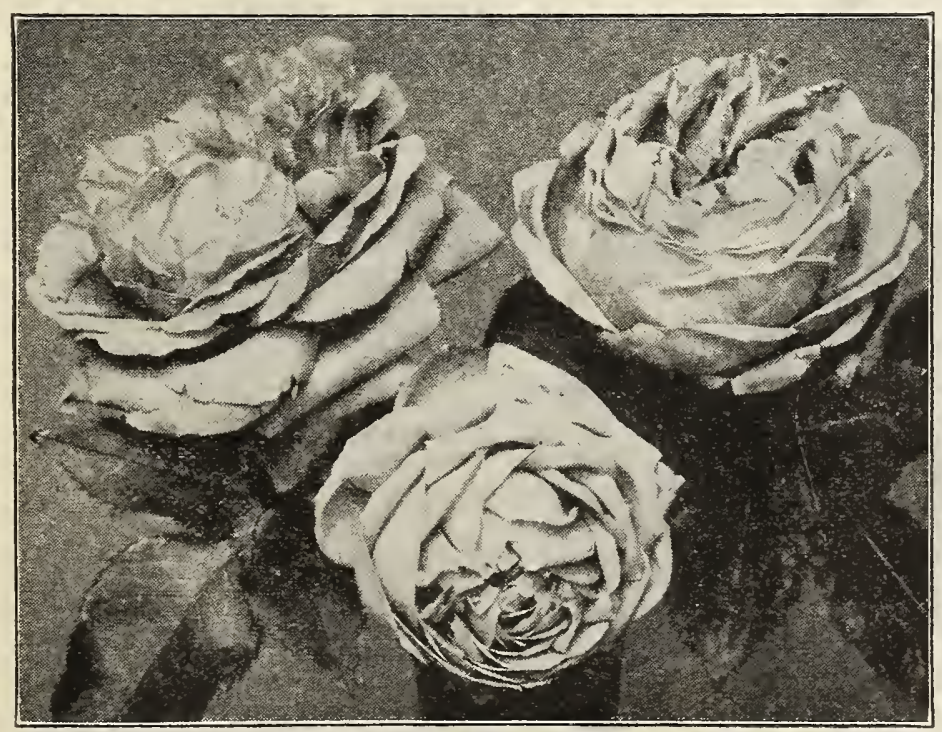

10 for $\$ 9.50$.

KILIARNEY-An exquisite shade of dee
bud and flower. Each, $\$ 1.00: 10$ for $\$ 9.50$.

and extremely showy. Each, $\$ 1.00: 10$ for $\$ 9.50$. MAMAM COCFIT-Light pin

rose. Each, $\$ 1.00 ; 10$ for $\$ 9.50$.

MARECHAI NIEI-The best everblooming climber, deep, rich re

low. Each $\$ 1.25 ; 10$ for $\$ 11.50$

PAUI NEYRON-Deep pink, immense size, the largest rose in cultiva-

tion. Each $\$ 1.00 ; 10$ for $\$ 9.50$.

IA TRANCE-H. T. Known the world over. Bright silvery pink Each, $\$ 1.00 ; 10$ for $\$ 9.50$.

ROSA RUGOSA AIBA-White, hlooms in cluster's, light green foliage, grows to the height of six feet. Each, $\$ 1.00 ; 10$ for $\$ 9.5$

ROSA RUGOSA RUBRA-Same as Rugosa Alba except color is red Each, $\$ 1.00 ; 10$ for $\$ 9.50$.

SUNBURST-The yellowest of all the

blooms in profusion. Each, $\$ 1.00 ; 10$ for $\$ 9$.

TAUSENDSCFON-Thousand Beauties: a hards climber.

shades from white to deep pink. Each, $\$ 1.25 ; 10$ for $\$ 11.50$.

WHITs COCHET-A creamy white faintly tinged with blush. Earl, $\$ 1.00 ; 10$ for $\$ 9.50$.

WMI. R. SMITH-A creany white with shadings of pink.

$\$ 1.00 ; 10$ for $\$ 9.50$.

DR. VAN FIEFT-Climber of the Wichuraiana or Memorial family Flowers very large, delicate flesh pink shading to rost-flesh in center. Each, $\$ 1.00 ; 10$ for $\$ 9.50$.

PAUI NEYRON DUCHESS OF WIIIINGTON-H T. Rich saffron.yellow tinger 43 


\section{NURSERY DEPARTMENT}

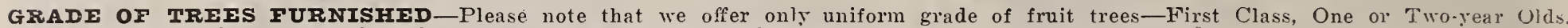

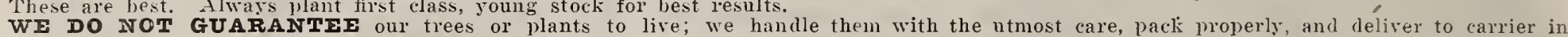
WE DO NOT GUARANTEE our trees or plants to live; we handle them with the ntmost
sood order. Our responsibility then ceases. The risk and cost of transportation is yours.

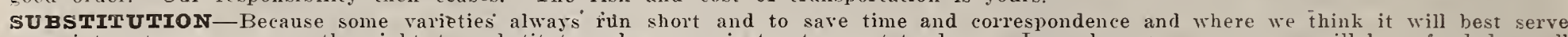

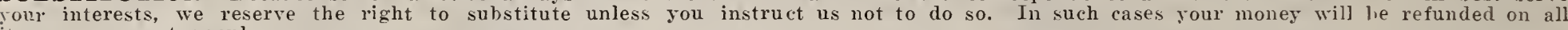
iteins we cannot supply.

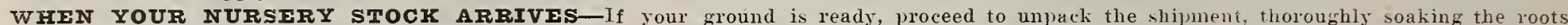

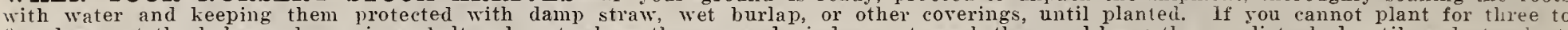

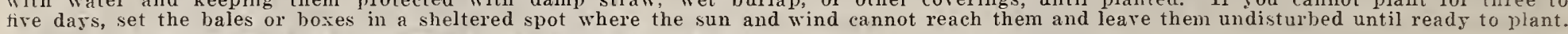
IF YOU CANNOT PIANT FOR FIVE DAYS OR IMRE-Then the trees or plants should be "heeled-in."

\section{P E A C H E S}

Three and one-half feet and up. Price $75 \mathrm{c}$ each; 10 for $\$ 7.00 ; 100$ for $\$ 65.00$

MAYFIOWER-The earliest and one of the very best early Peaches. Fruit round, entirely covered with red; blooms late, very hardy. A native of North Carolinis a good shipper, and its high color and fine appearance make it the most profitable earl
always brings top prices. Last of May.

ARP BEAUTY-The earliest vellow flesherl Peach of high quality; firm, juicy, excellent fiavor; freestone.

CARMaN-Large, resembling Elberta; white, tinged with red; good flavor. A good shipper. Freestone. Middle of June.

EARIY BEIIE OR HIIEY-A Georgia Peach, and Early Tillotson. Large; creamy white, highly colored cheek. One of the profitable commercial va-
rieties of Georgia, and now being extensively rieties
planted.

BIIIE OF GEORGIA-Very large; white skin, attractive red cheek; flesh white; the standard bearer. It is one of the best market varieties of its season.

EIBRRTA-Known wherever Peaches are eaten. Of Georgia origin, remarkable for its size; firm,

yellow flesh and tough skin, making it one of the best shipping Peaches; yellow, slightly overspread with red; fine red cheek. Free
stone. Middle of July.

CHINESE CIING-Very large; yellowish white, mottled with carmine; flesh white, red at the tip; a very juicy Peach. Clingstone. Find of July.

BIOOD CIING, OR INDIAN BIOOD-Large; dark claret with (ieep red veins; Hlesh deep red: middle to last of August.

KRUMIMI-A large beautiful peach that always finds a fine market. Yellow flesh; rich yellow skin with dark carmine cheek: freestone, ripening last of September.

J. H. HAIE-No peach has had such strong claims for superiority and productiveness as has this, which bears the name of America's greatest Peach grower who discovered it. Larger than Elberta, of better flavor and quality; it ripens, in the South, a few days later. better flavor and quality; it ripens, in the South, a few
and is a perfect yellow-meated freestone. Fine shipper. tough, creamy white, with deep blush; Hesh creamy supposed to be a cross between Belle of Georgia

\section{P E A R S}

Four and one-half feet and up. Price, $\$ 1.25$ each; 10 for $\$ 10.00$ 100 for $\$ 8500$. Plant 18 to 25 feet apart.

FARIY FARVIST-One of the best early sorts, fruits medium size. rellow with dark red cheeks, delicious flavor. Ripens in june. Tree strong, shapely grower. GAREER-Large beautiful yellow fruit, very delicious in flavor.

KIPFrER-Golden yellow, tinged with red on one side, remarkably free from blight; ripens in September.

IE CONTE-Of good size, bell-shaped. Tree a vigorous grower and bears young. Of same general type as Garber and Kieffer but matures earlier. SECKII-This little pear is the standard for flavor. Yellowish russet with red cheek; juicy and melting. Tree is of slow growth and never attains great size. Argust.

\section{Q U I N C ES}

Three feet and uy. $\$ 1.25$ each; 10 for $\$ 10.00$ CHAMPION-Large, very showy and handsome tender and rich in flavor.

ORANGE-Large, round, golden sellow; very

\section{A P R I C 0 T S}

Three and one-half feet and up. Each, $\$ 1.25$ 0 for $\$ 10.00$

EARIY GOLDEN-Small, pale orange, juicy and sweet. WIISON-Deep yellow, red cheel, large size.

\section{NE C T A R I NES}

Three and one-half feet and up. Each, $\$ 1.25 ; 10$ for $\$ 10.00$. NIW WIITr-Medium large, nearly round; white flesh, tender juice.

RID ROMAN-Largest size; greenish-yellow, with a dull red cheek; flesh rellowish; pleasant and good quality.

\section{JAPAN PERSIMMON}

Three feet and up Each, $\$ 1.25 ; 10$ for $\$ 10.00$

\section{FIG BUSHES}

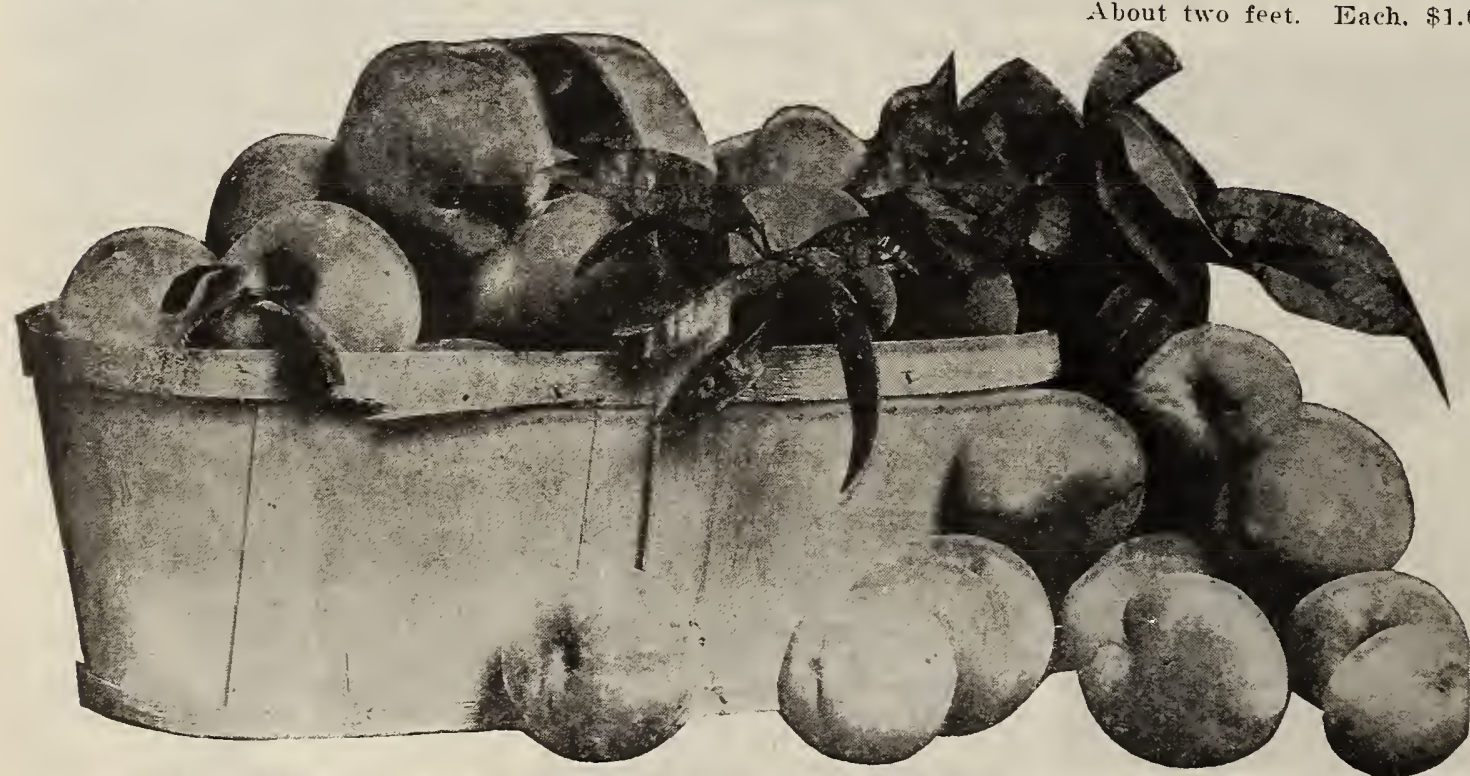

MAYFLOWER, VAIUABIE TO SOUTHERN GROWFRS AS AN IARIY EORT BROWIN TURTEY-Large and productive. CrIESTIAI, or CEIESTELight violet in color; very pro lific: excellent quality.

\section{P L U M S}

Four feet and up, \$1.25 each 10 for $\$ 10.00 ; 100$ for $\$ 85.00$. WIID GOOSE-Large fruit of oblong shape; skin bright vermilion covered with blue bloom: richly acid. One of the oldest and best known of the native American Plums. Ripens end of June. BURBAN K-Large, clear, cherry red, very sweet.

DAMSON-Bush purple, fine for cooking; ripens in August.

wICKSON - Purple red, firm, sweet and juicy.

FRANCES-A cross between Apricot and Japan Plum. Of 'Texas origin where it ripens last of June; fruit of good size, yellow, June; fruit of good size, rellow,
handsoine. Tree resembles Plum more than Apricot; strong grower. 


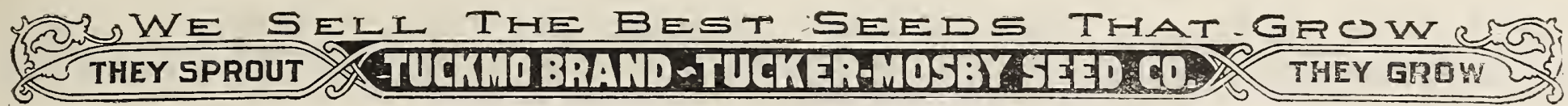

\section{APPLES, THE KING OF FRUIT}

Only Standard Yarieties. Instead of constantly adding new and untried rarieties to oul list, we are showing only such sorts that we know are best adapted for general une.

Plant 25 to 35 feet apart each way according to the soil.

Three and one-half feet and up, $75 \mathrm{c} ; 10$ for $\$ 7.00 ; 100$ for $\$ 65.00$

\section{STMMER VARIETIES}

CAROIINA RID JUNE-Well known throughout the South. Medium size oblong deep red; it ripens from middle of June to the end of $\mathrm{July}$

FARIY HARVEST-Medium to large; pale yellow; fine liavor. Tree moderate, erect grower, good bearer. Beautiful and excellent variety for dessert and kitchen. Ripe in . June. FoRs

HACKWORTH-A native of Morgan C.o., Alabama, twenty miles north of Huntsville. Tree a very strong grower, adapted to a wide range of soils and elevations. Fruit mrdium to large, of good appearance and quality. Ripens in July and through August.

\section{FALL AND WINTER VARIETIFS}

RED REESE-Larger than Winesap, bright red, shape much like Delicious. Ripens in early fall but keeps well into the winter.

STAYMEN WINESAP-A seedling of WVinesap, but a thorough grower and a bette adapter to thin soils; much like Winesap in size and appearance, but of better quality
DEICIOUS-A very popular apple in the West and Northwest. Very large, oblong color rich crimson shaded to yellow; fine grain, juicy; a fine keeper and shipper. Not ye thoroughly tried out in the South.

WINESAP-Medium size, roundish; deep red; flesh yellow, firm, crisp, juicy; excellent quality; a leading export variety. Tree moderately vigorous with open irregular head; very productive and an early bearer.

YATPS-A small apple, but one of the surest croppers, heaviest bearers and best kefp ers. Dark red with white dots; flesh yellow, crisp and good

TOWRY-Medium to large, of perfect shape and very uniform in size Sui-acid, rer. juicy and solid; one of the finest keepers in storage.

almost solid red. Quality high.

\section{H E R R I E S}

lach, $\$ 1.25 ; 6$ for $\$ 6.00 ; 12$ for $\$ 11.00$. BLACK TARTARIAN - Very large; purplish black, heart-shaped; flesh mild and sweet ani quality considered the very best for market and dessert. Tree is a vigorous upright grower and

\section{immense beare}

GOVERNOR WOOD-Large, round, heart-shape yellow, mottled with red; flesh is sweet, juicy and delicious. Tree healthy, vigorous: great bearer. Fruit hangs well on trée. June. FARIY RICHMOND Medium size, light red sprightly acid flavor. This is popular of the cherries, and popular of the cherries, and is unsurpassed for cooking purposes. Tree a splendid productive. The most hardi IARGF MONTMORENCY -Large, round, handsome red: lesh fine lavored, sil acid; rich. Fecommended for kitchen use and is unexcelled for close market shipping. Tree is a good grower, very hardy and produces enormous crops of fruit; seldom if ever failing to bear. A very desirable variety for the small market gardener.

\section{0 M PASS CHERRY PLUM}

A cross between the Sand Cherry and the Miner Plum. Fruit about 1 inch in diameter, bright red, when fully ripe a dark rich reil. $\$ 1.25$ each; 10 for $\$ 11.50$.

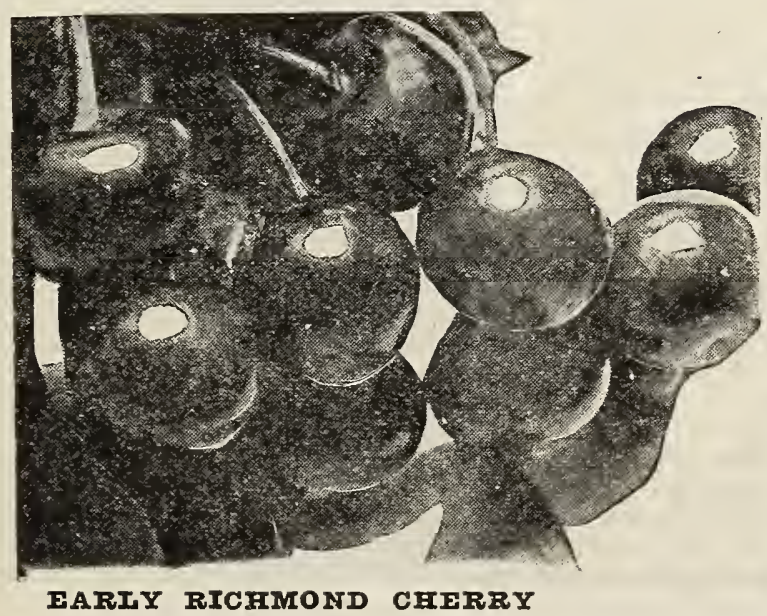

B L A C K B E R R I E S Each, $15 \mathrm{c} ; 10$ for $\$ 1.25 ; 100$ for $\$ 10.00$ SNYDER-Medium size, very harly; an old, well-known sort. Berries of me dium size, sweet, melting; very hards and wonderfully productive. Leads where hardiness is a consideration. Early. ELDORADO-Very rich, large, spark FARIY HARVEST-Canes dwarfish In sections subject to cold winters should be protected. Very desirable on accoun

\section{E W B E R R I E S}

$15 \mathrm{c}$ each, 10 for $\$ 1.25 ; 100$ for $\$ 10.00$ LUCRETIA-The berries are far large and incomparably better than any black sweet and luscious throughout, of brightest glossy black color.

AUSTIN IMPROVED-Very deliciou and productive.

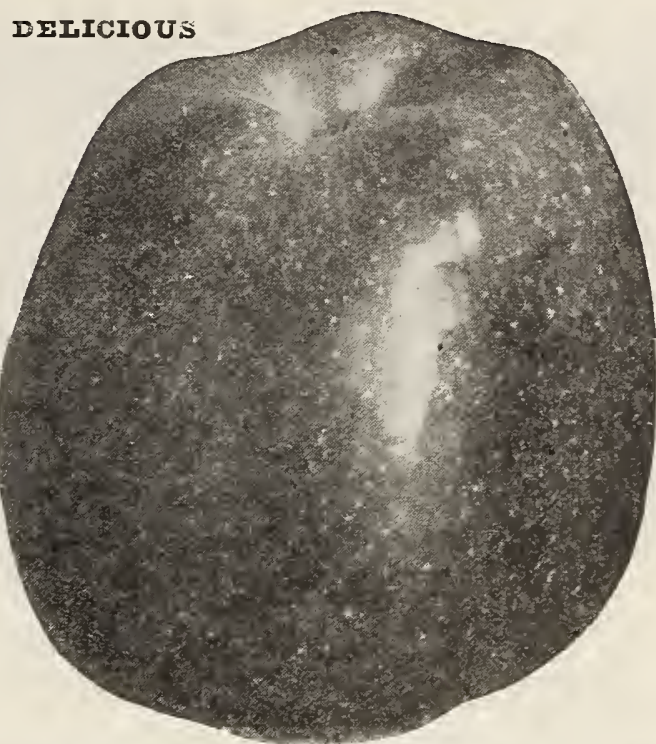

(i O OSEBERRIES AND C URR A N T S WIIDER CURRANT-TerY large; a splendid market not so acid as most. Bush vely productive large bunches; ripens early; fruit keeps well. roundish pale red; tender sweet, very goor and berries are very deliciously fiavoled. Tery profitable for canning or for catsup. Bush vigorous, slender and rather spread. Enolmously productive Sel
dom mildews. Ripens early.

\section{G R A P E S}

Each, $35 \mathrm{c}$; 10 for $\$ 3.00$; CONCORD for $\$ 25.00$. - The fine old luscious grapes. Entirel hardy, productive and reli able; succeeds well over great extent of country. known grape. September. large dark red berry; most agreeable flavor.

WOADEM - A very popula black grape, seedling of Concord but distinct in flavo NIAGARA-Its clusters ar large and handsome, compact $r$ filled with large berries. liaving a thin but tough skin. When fully ripe they are fine pale yellow, with a thi white bloom, and foxy aroma of an earlier Ripens witl Concord. 


\section{R A S P B E R R I E S}

Price, by express, each $15 \mathrm{c} ; 10$ for $\$ 1.25 ; 100$ for $\$ 10.00$. CUMBERLAND-The largest black raspberry grown; coal black berries; very firm and quality of the very best; excellent shipper. Bush a strong grower, stocky canes and unusually prolific. Midseason.

CUTHBERT-Very large, conical; rich crimson; very handsome and firm; flavor sweet rich and luscious; a great market sort and will stand shipping long distances. Busn hardy, both north and south; stocky, upright grower and productive; red berries; ripens middle of May and continues for several weeks.

ST. REGIS EVERBEARING RASPBERRY-One of the greatest raspberries ever introduced. Plants of the St. Regis put out in the fall or early April gave ripe berries on the 20 th of June. For four weeks thereafter the yield was heavy and the canes continued to produce ripe fruit without intermission until late October. The berries were large and beautiful, firm and full flavored to the very last.

\section{S C U P P E R N O N G R A P E S}

WHITE and BIACK, JAMES and THOMAS-Each, 55c; 10 for $\$ 5.00$.

\section{STRA WBERRIES}

Plant in February, March, April and November on good ground, deeply worked and well manured. Set in rows three and one-half feet apart, fifteen inches in rows for field culture, fifteen inches apart each way for garden. Cultivate clean, mulch late in the fall of manure.

FAIL OR EVERBEARING STRAWBERRIES-A new species different from the ordinary strawberry, in that they bear in the fall. The regular sorts require a full yeare growth to come into bearing and weeks, while the Everbearing plants set out in the spring bear from July until freezing time the same year they are planted and ing the the sain the following spring, same then other kinds.

THOMPSON-Well known standard va riety for home use; fruits large, slightly pointed, light red, but very sweet; perrect blooming.

AROMA-Very large, late maturing, berries solid, deep red, uniform in size; does well in this section. Perfect blooming. KLONDYKE-A Southern berry, one of the best; color dark red and good size. Flowers perfect.

MICHEI-Largest, most brilliantly colored and most strikingly beautiful of all ber. ries. It is truly glorious. King of markets A truly Southeri without an equal in its line.

DUNIAP-An old, well-known variety makes plenty of well rooted, healthy plants: medium in season, bright red berry with golden seeds; the flesh is firm, red and of excellent flavor; enormously productive and seems to do well wherever planted.

EXCEISIOR-The Berries are of medium size. enormously productive and extra early, firm as rocks. The berries are very highly colored, deep fine flavor.

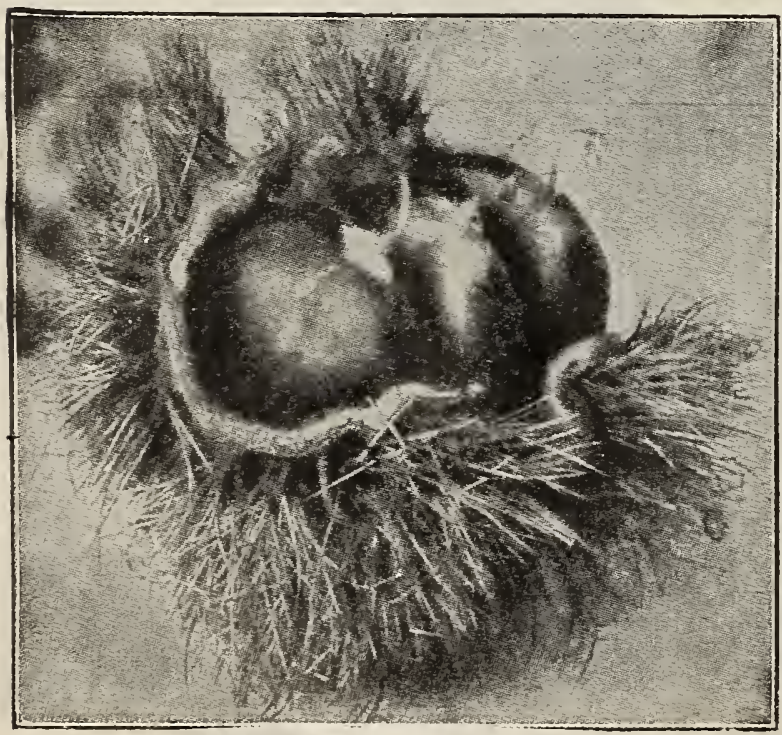

SPANISH CHESTNUTS

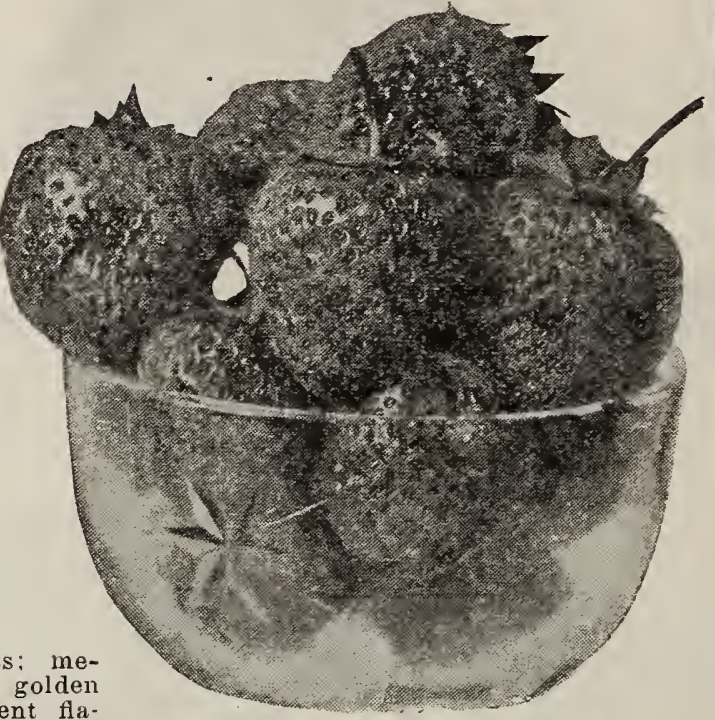

DUNLAP STRAWBERRIES

PRICE IIST OF STRAWBERRY PLANTS

All amounts up to 100 plants of each variety come post paid. All lots of 250 up come express collect.

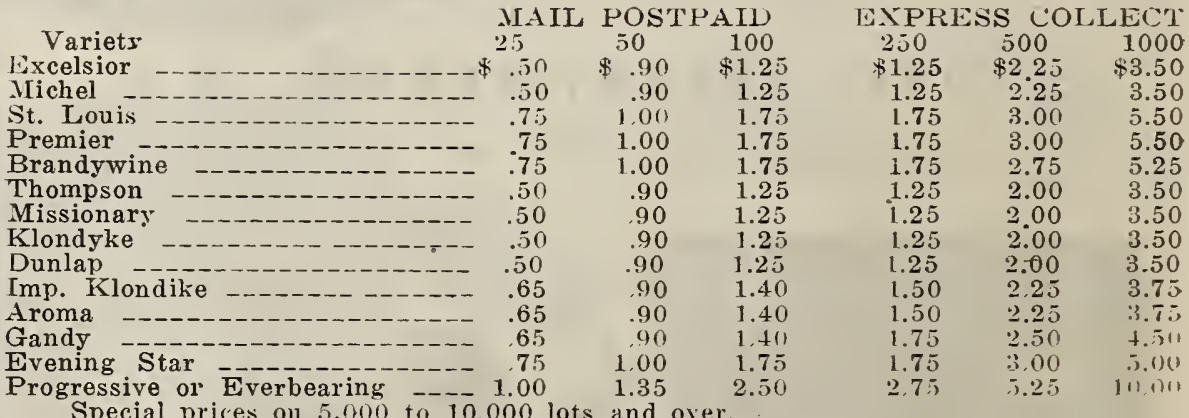

\section{NUT TREES}

Our Nut Trees are the kind that grow and beside furnishing abundant crops of fruit, they make the finest shade trees for the lawn and streets.

PECANS-Grafted or budded, about two feet. Varieties: Stuart, Schley. Mones maker. $\$ 1.25$ each, 10 for $\$ 11.50 ; 100$ for $\$ 95.00$.

CHESTINUT (SPANISH)-A handsome round-headed tree, producing abundallt crops; about $3 \frac{1 / 2}{2}$ feet. $\$ 1.25$ each; 10 for $\$ 11.50$

CFESTNUT (JAPAN IMPROVED)-About three feet. $\$ 1.25$ each; 10 for $\$ 11.50$ WAINUT-ENGIISH, JAPAN AND BLACK-About $2 \frac{1 / 2}{1}$ feet. These trees are ideal for shade purposes as well as their enormous crops of fruit, and the wood is highly prized for furniture and cabinet work. $\$ 1.25$ each; 10 for $\$ 11.50$.

AIMONDS-I $\mathbf{X}$ I AND NE PIUS UITRA-Both of these varieties are thin helled which are in such great demand on the markets. Each $\$ 1.25 ; 10$ for $\$ 11.50$. 


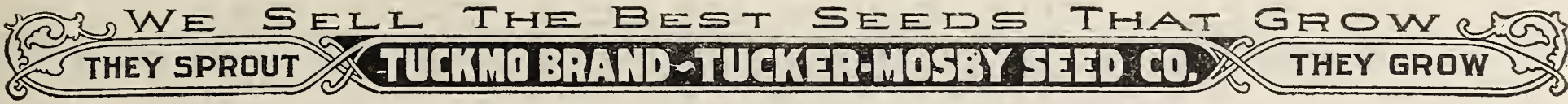

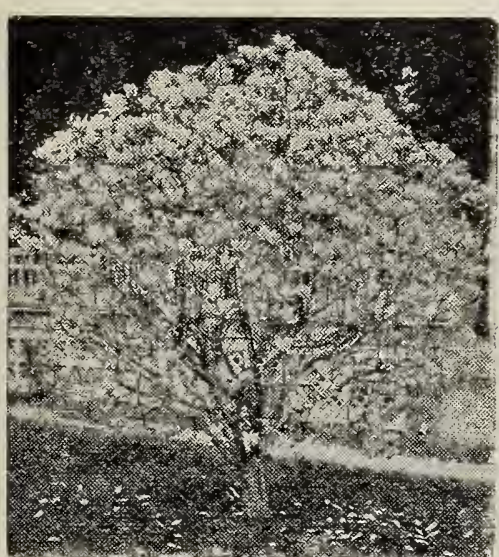

MAGNOIIA GRANDIFYIORA

ORNAMENTAL TREES

(Shade Trees)

CATAIPA BUNGEII-Round head, 4 to 6 foot tems. Very hardy and effective for lawn or formal gardens. Each, $\$ 2.75$.

DOGWOOD (WHITE FIOWERING) - Three to four feet stems. A small bushy tree with upright or spreading branches. One of the most beautiful flowering trees grown. Leaves bright green turn. ing red or scarlet in the fall. Indispensable for
lawn or landscape. Each $\$ 1.75$.

DOGWOOD (RED FIOWIRING)-Thre

four feet stems. A strikingly beautiful form, espe. cially when planted in contrast with the white. lowered or tropical forms. The floral bracts are of a bright pink color. Each, $\$ 2.25$.

MAGNOIIA GRANDIFIORA - Two to three feet stems. A large shrub or tree; leaves dark green, expanding after the flowers have fallen; flowers large cup-shaped whit
fragrant. Each, $\$ 2.25$.

MAPIE (SIIVFR IFAF)-About eight feet. A rapid growing tree of large

irregular rounded form; foliage bright green above and silver beneath; a favorite tree for streets and park; attains about the same height or taller than the Norwar. Each, $\$ 2.25$.

SUGAR IMAPLE (ROCK)-liarge trees to except in with gray bark. Long lived. Grows well axcept in damp, soggy soils. An excellent street and shade tree of upright, dense growth. Leaves turning bright yellow and $\$$.

GUI, SWEET (Liquidambar)-A native tree of moderate growth. Each, $\$ 1.50$.

NORWAY MAPIE-Very popular on account of its clear, large leaf of deep, rich green, stout, vigorous growth. Each, $\$ 2.25$.

IOMBARDY POPIAR-About eight fee stems. Attains a height of from 100 to 150 feet: well known for its erect, rapid growth and tall spiry form. Each, \$1.75.

HACKBERRY - A handsome tree witl stout spreading branches, forming a round-topped crown; fruit nearly black at maturity. like small cherry, $\$ 1.25$ each.

JUDAS TREE, OR RED BUD (Cercis canadensis)-One of the smaller trees. especially good for masisng with Dogwoods, also for wrou: and for screens. Each $\$ 1.75$.

OAI PIN-A symmetrical tree with drooping branches. Each, $\$ 2.25$

PIUM PURPIE IEAVED - Ornamental dwarf habit, foliage dark purple. Wach, $\$ 1.7$. CHINA UMBREIIA-Four to five foot stems. AMERICAN FIM-About eight foot stems. Tery valuable fo park planting, for avenues, and as a shade tree for lawns. One of the most majestic and graceful of our shade trees. Hardy, rapid grower, resists drought well, and is long lived. A magnificent tre growing 80 to 100 feet high. The Elm is a native of America and thrives in almost ans location. Each $\$ 1.5$

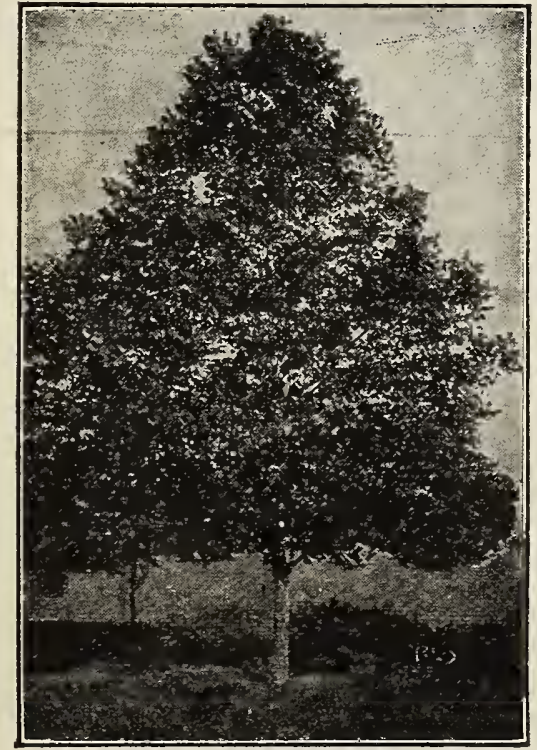

AMIRICAN FIM

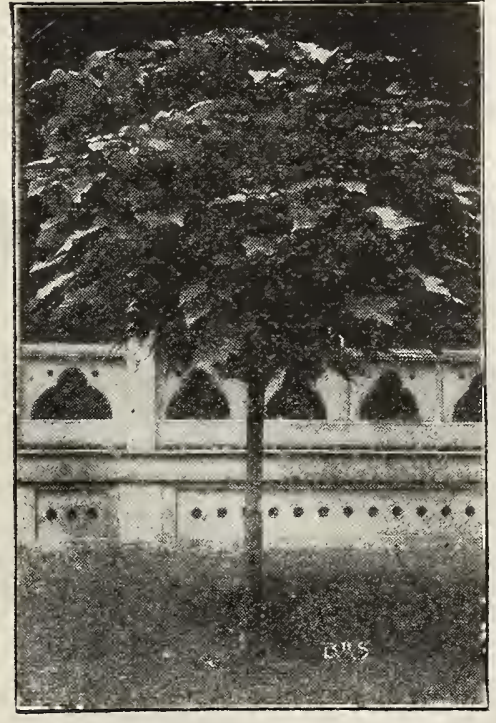

CATAIPA EUMGEIT

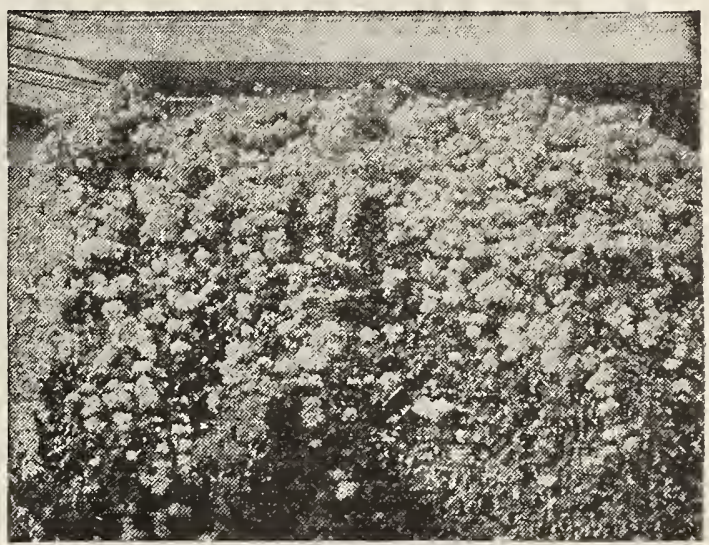

CIIMATIS PANICUIATA

HARDY CLIMBING VINES

(One and 'Two-Year)

A IM I I PSIS QUINQUEPOIIA (VA CREFPER) - A very rapid grower and entirel tardy. Each, 60c; 10 for $\$ 5.00$.

HENRYII CIEMATIS-Very hardy, cream white, fine form. a free grower and bloomer. Wach, $\$ 1.25 ; 10$ for $\$ 11.50$

JACKMANII CIFMATIS-intense viole- pur ple; flowers are 4 to 6 inches in diametex when ung expanded. Each $\$ 1.25 ; 10$ for $\$ 11.50$.

MAD. FD. ANDRE CIFMATIS-Color a dis inct crimson-red; flowers very large and velvety; strong and vigorous. Each, $\$ 1.25 ; 10$ for $\$ 11.50$

CIEMATIS PANICUIATA - Single white Each, 70c; 10 for $\$ 6.50$

FAII'S JAPAN (Climbing Honeysuckle) Yery white and creany yellow; very fragrant; i bloom the whole season. Each, 60c.

SCARIET TRUMPET-CIIMBING HONEY SUCTIE-Strong and rapid grower. $\mathrm{Ha}$ trumpet-shaped flowers of a beautiful red color Makes a very attractive vine when in bloom and reatly adinired, Each, $65 \mathrm{c} ; 10$ for $\$ 6.00$

KUDZA VINE (P. GRACEA)-A magnificent climbing vine for all purposes, growing 40 to 50 feet in a season especially adapted to cov
Each, $65 \mathrm{c} ; 10$ for $\$ 6.00$.

WISTARIA, CHINESE PURPIF-One of the most elegant and WISTARIA, CHINESE WHITE-Grafted. $\$ 1.25 ; 10$ for $\$ 11.50$

HE D G E P L A N T S

With just a little attention to clipping, stately Privet Hedges can be afforded and enjoyed in every hoine, no mat. ter whether it be the pride of the laborer or the extravagance of the millionaire.

The plants are not expensive, are certain to grow and can be trimmed into the most fantastic shapes as to make it $a$ narrow, wide, round or flat on top at the will of the owner, or a select few of them can be left to take on greater height. CAIIFORNIA PRIVIT-Very popular in the North and East, and planted all through the South, but in our opinion not as desirable as the Amoor River, because it often loses ts foliage early in the winter. Well-branched plants, each, 100 for $\$ 8.00$

AMOOR RIVER PRIVET (I. AMBURENSF)-A valuable ornamental shrub for hedges and borders; very hardy, foliage glossy green and holds its color almost the entire vear; will stand shearing to any extent. About eighteen to

\section{U L B E R R I E S}

Four to five feet. Each, $\$ 1.25 ; 10$ for $\$ 11.50$ RIACK FNGIISH-Very ornamental; black fruit of grood flavor.

EVTRBgARING-A very desirable sort HICKS-Ornamental and fruiting

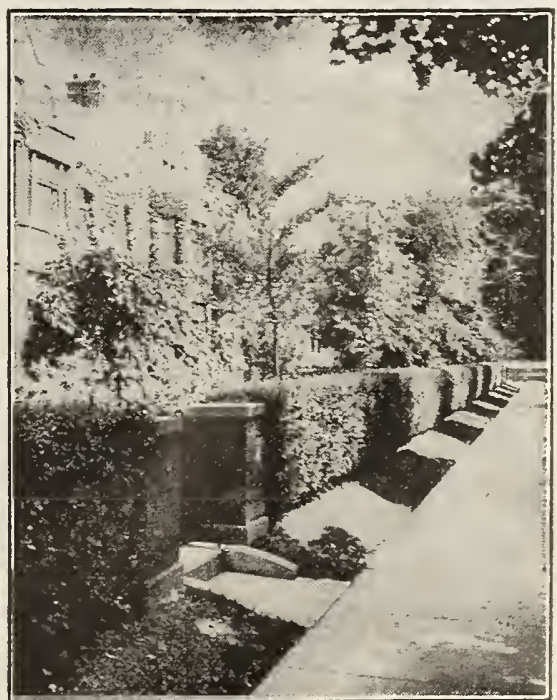

CAIIFORNIA PRIVET HFDGE 


\section{Coniferous and Broad-leaved Evergreens}

ARBORVITAE, CIINESE-A compact and narrow pyamidal tree; its branches are short and densely clothed with bright
grower. $21 / 2$ to 3 feet. Fach, $\$ 2.75$.

ARBORVITAE, DWARF GOIDEN-12 to 18 inches. A very compact, globular type. Handsome shade of green. Fine as individual specimen or for border plantings of higher growing evergreens, Suitable for small gardens, Each $\$ 3.50$.

AREORVITAE, ERECT GOLDEN-15 to 20 feet with grolden yellow foliage. A very beautifui specimen of the evergreen family. Each, $\$ 6.00$.

AREORVITAE, COMPACT-Attains height of 5 to 6 feet. Bright green toliage. Low A cirk cemeteries. Each, $\$ 3.25$.

AREORVITAE, ROSEDAIE-Attains height of 3 to 4 feet Tree is cone-shaped with blue-green foliage. Each, $\$ 4.50$.

CFDRUS DEODARA-Attains height of 30 feet; rapid grower. Each, $\$ 3.00$

BIUI VIRGINIA CEDAR-Attains height of 30 feet; silvery blue foliage.

stately tree and much admired. Each, $\$ 9.00$.

RED CEDAR-This evergreen attains a height of 100 feet, with conical head and spreading or upright branches. The leaves are spiny pointed. Each, $\$ 8.50$

IRISH JUNIPER-A slender, columnar form with numerous upright branches; inval uable in Italian gardens and whose architectural features are desired; foliage glaceous green. Each, $\$ 2.25$.

SPRUCE, NORWAY-Picea excelsa. Prramidal habit. Very popular, Makes specimen or lawn tree and widely used in windbreaks. 18 to 24 inches, each $\$ 2.25$ EVIRGREEN BITTERSWEFT-Destined to become the most popular of Evergieen For the beautifying of old tree trunks, stumps, garden walls, it has no equal. It absolutely holds its beautiful color at all times, winter or summer. Bears a profusion of red berries in fall and winter. $\$ 1.25$ each.

JAPAN PRIVET-A very hand some evergreen shrub with dark rich
foliage. Will attain height of 10 feet or more. Each, $\$ 2.00$.

CYPRESS, JAPAN-Low brancheil CYPEESS, GOIIEN PIUMEDYoung growth is a beautiful golde color. Each, $\$ 3.00$

HEMIOCK, AMERRICAN-A tall rraceful tree that can be used to great adrantage as windbrealis. Each 4.50

AREIIA-Flowers resembl

CAPI JASMINE-A BOXWOOD, BUSF FORM (Buxns sempervirens)-.-Tree Box, natural bushes not sheared. This is the form
of Boxwood from which the formal shapes-pyramidal, globe, ball, etc. to 18 , balled $\$ 2.25$

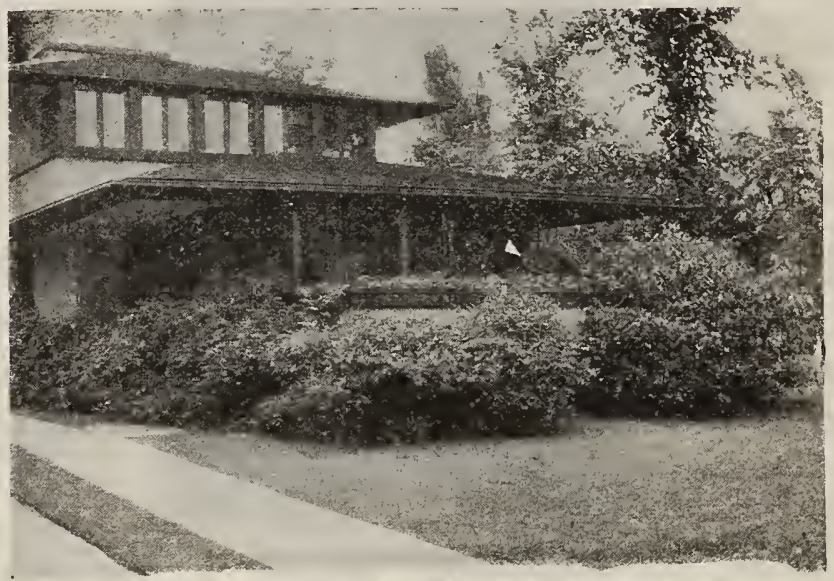

AN ATTRACTIVE EVERGREFN PIANTING

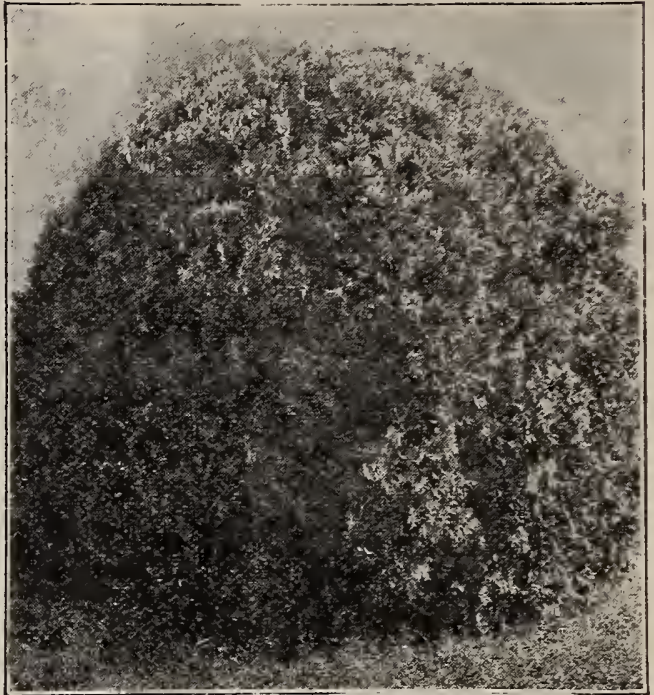

ROSEDAIE ARBORVITAE

DECIDUOUS SHRUBS AITHEA-ROE OF SHARON-Amon the most desirable shrubs for fall planting. We also have the following six varieties; Doubl Red. Double Purple, Single White, Double White, Single Red. Single Blue. Each. $75 \mathrm{c}$ 10 for $\$ 7.00$.

BARBERRY - PURPIE IEAVED - Retains its color throughout the season. $75 \mathrm{c}$ each: 10 for $\$ 7.00$.

RASPBERIY THUNBERGIIgraceful shrub with drarf habits bright green foliage with rifferent
sliades of berries. $75 \mathrm{c}$ each: 10 for $\$ 7$. BUTTERTI BUSF-A great profusion of Lilac colored flowers. Each, $75 \mathrm{c}: 10$ for $\$ 7.00$.

CAIYCANTHUS-Produces $s_{i}$ chocolate colored flowers. Each. 75c: 10 for $\$ 7.00$

CORAT BERRY-A small shru\} producing red berries in profusion Hoursucer varieties. Fragrantissima, Red and White Tartarian. The Honeysuckle is too well known to need any descrip tion, but we urge the planting of more of these deliciously fragrant plants. Each, 75c; 10 for $\$ 7.00$.
Yach, $\$ 1.25 ; 10$ for $\$ 11.50$.
YUCCA (Adam's Needle or Bear Grass) - A peculiar plant,

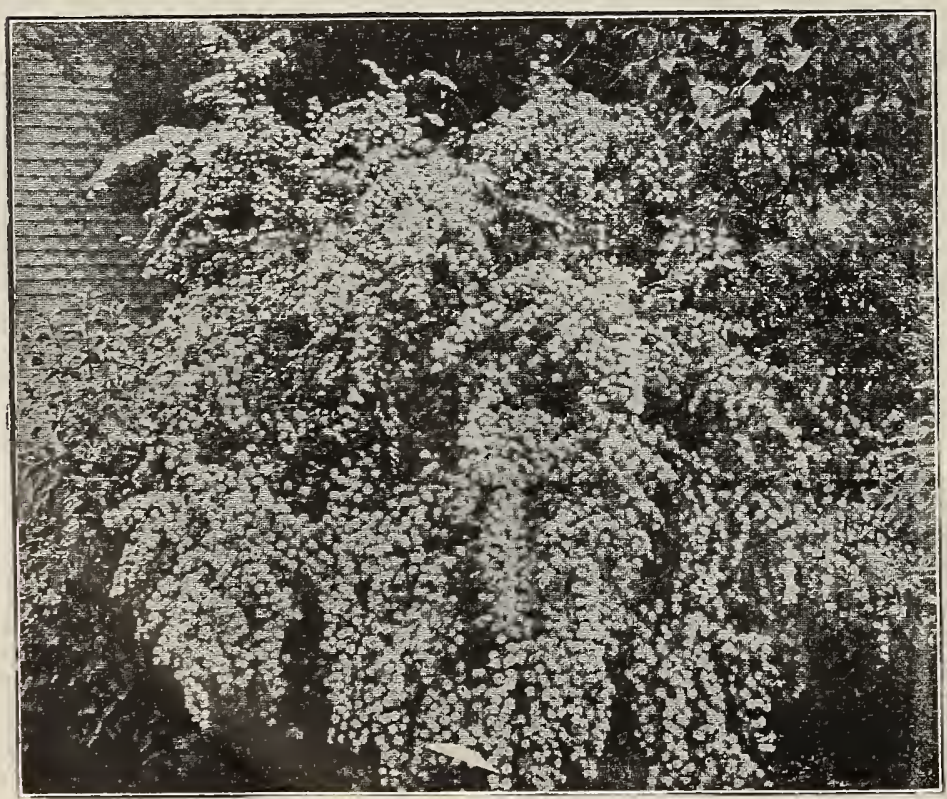

SPIREA, BRIDAI WREATH
DEUTZIA-Large double white flowers. Each, $75 \mathrm{c} ; 10$ for $\$ 7.00$. FORSYTHIA-GOLDEN BEII-The earliest blooming of all shrubs. HYDRANGEA-Oak Leaved, Gold Flower and Kerria White-A ver useful shrub when used as a background for landscape gardening, th large bright colored flowers lending a beautiful effect. Each $\$ 1.2510$ large bright

IRIS-The Iris or Flag is of easy cultivation, white, pink, yellow, violet. Each, $60 \mathrm{c} ; 10$ for $\$ 5.50$.

SPIREA-Bridal Wreath, Crimson, Single White. Double WhiteThere is no more dependable shrub than Spirea. Its graceful foliage and growth and the beautiful blossoms are a delight the season through. A selection of varieties planted in masses or rows will assure continu. ous bloom to the end of summer. Each, 65e; 10 for $\$ 6.00$.

SNOWBERRYS-Slender branches, pure white flowers. Each $75 \mathrm{c}$ for $\$ 7.00$

WEIGEIIA-Pure White, Deep Red and Light Pink-Very attractive when planted as specimens. Each; $\$ 1.00 ; 10$ for $\$ 9.50$.

PEARI BUSHI-8 to $10 \mathrm{ft}$. Pure white flowers, abundance in the early spring. Each $\$ 1.00 ; 10$ for $\$ 9.50$

SNOWBAIL (COMmON)-A favorite well known.shrub. $\$ 1.00$ each, 10 for $\$ 9.50$.

SNOWBAII (JAPAN)-Beautiful foliage, pure white flowers. $\$ 1.25$

SYRINGA (MOCX ORANGE)-Old fashion shrub. $\$ 1.00$ each: 11 IILAC (PURPLE)-The old fashion lilae. $\$ 1.00$ each; 10 for $\$ 9.50$. IIIAC (WHITE)-Much like the mirple. \$1.01 each; 10 for $\$ 9.50$ 48 


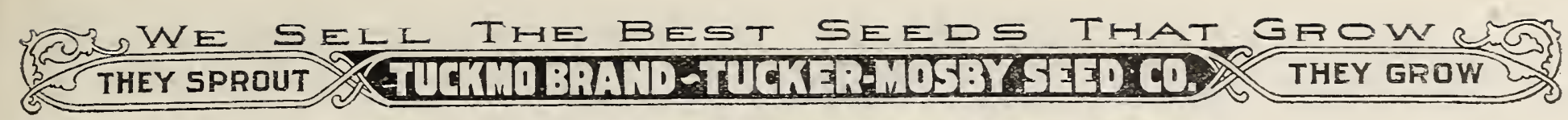

\section{Tucker-Mosby Seed Co.'s Thorough- bred Seed Corn}

Corn is the most important crop with the majority of farmers who will read this catalog; consequently, we are de voting considerable space to the description of the different varieties we consider to be the very best of their type. Ou stocks are the product of carefully selected seed stock and of crops that hare received every care necessary to the production of a grade of corn that can be recommented as strictly seed stock. We consider that we are listing these at ver reasonable prices, considering the high standard of quality which we know they represent.

When you stop to think that at our prices it would only cost you from 35c to $40 \mathrm{c}$ per acre to plant seed that will produce you a crop vielding, perhaps many bushels in excess of that which you would harvest if you plant inferior seed, we believe you will agree with us that the purchase of a few bushels of some of these select strains would prove to be a gooc investment. We would appreciate your order for any quantity and are prepared to make special prices on large lots.

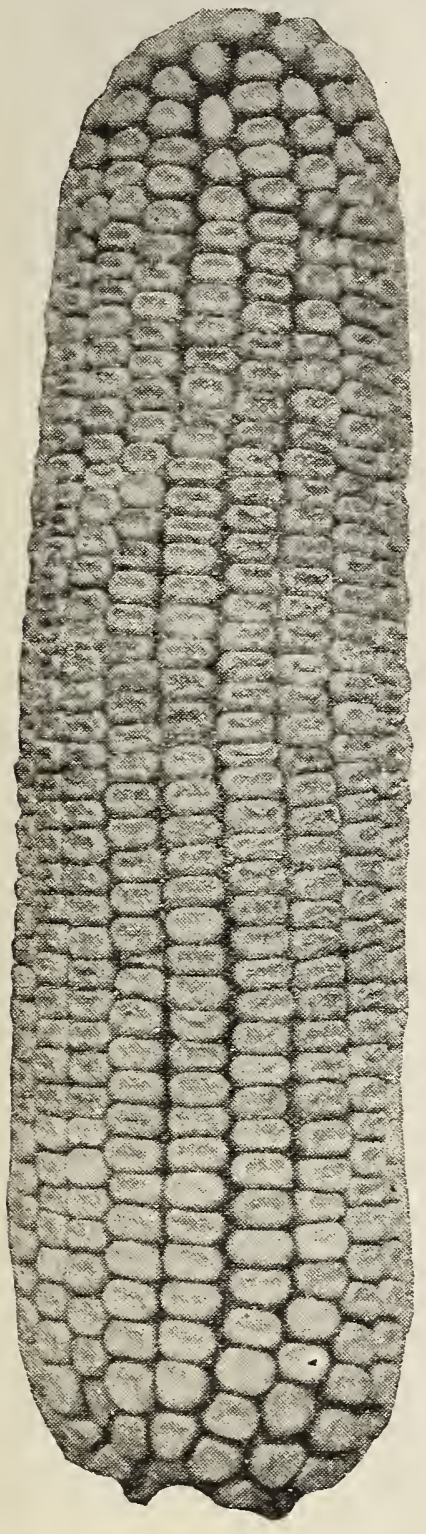

COCKE'S PROIIFIC
GOLDEN BEAUTY - A rer fine yellow corn. Ear's from eight ately tall. The ears have from 1 to 16 rows. Ears are well inlled from butt to tip. Often produce Quart, 30c; 4 quarts, $75 \mathrm{c} ; 1$ peck. $\$ 1.35$, postpaid. Not prepaid. peck, $75 \mathrm{c} ; 1$ bushel, $\$ 2.50$.

TUCKMO NEIIS PAYMAS TrR-An improvement over the old Neils Paymaster. A medium size ear with white red cob, medium size stalk, averaging two zood ears to the stalk. The ears is a 100-day corn and will make more corn per acre than any of the large ear varieties. It has been planted extensively in the South and has given universal satisfaction. Price, quart, 30c; 4 quarts, prepaid, peck. $85 \mathrm{c}$; bushel, $\$ 3.00$ MAMMOTH RED COB WHITE DriNT-One of the best all round
white sorts for rich land, producing largest crops of finest produlity corn. The ears average about 10 inches in length, of uniform size and great depth of grain, rows 18 grains are pure white, solid, ver deep, producing the finest milling white corn. The rield of this superior corn is verr large, sometimes as much as 90 bushels per acre. We unhesitatingly recommend it, both for yield of grain or using for ensilage. Quart, $30 \mathrm{c}$ + quarts, $75 \mathrm{c} ; 1$ leck, $\$ 1.25$; post puid. Not, $\$ 2.50$

BRAZIIIAN OR STOOIING FIOUR CORN-A grand stool ing sort, and each kernel produces bears two to three beautiful white bears two to three beautiful whit paid. By freight, 4 quarts, TUCKER'S BLUE RIBBON EARLY WHITE-A grand variety of field corm introduced br the Tucker-MIosbr Seed Co., and is by far the earliest large Dent Corn in existence, and also the larges Early Corn, of very strong, vigorous character, growing inore rapidl than any other variety, from the day it is planted it really surprises one with the speed it hurries ou to make ears. Leaves quit broad, of dark emeralc. green, healthy color. Planted as late as July 10, has yielded a splendid crop. We claim it will mature in
85 to 90 days. Ears are larger and smoother, easier to handle than 85 to 90 days. Ears are larger and smoother, easier to handle tha large as some other varieties grown in the South. Fully 40 per cent of the stalks produce two good ears, well filled to the tip. Quart. $30 \mathrm{c} ; 4$ quarts, $75 \mathrm{c} ; 1$ peck, $\$ 1.35$; postpaid. Not prepaid, 1 peck, $85 \mathrm{c} ; 1$ bushel, $\$ 3.00$

TUCKER'S BLUE RIBBON EARLY YELLOW-Sinilar Tuckers Blue Ribbon Early White, only difference in color. Quart, $35 \mathrm{e} ; 4$ quarts, $75 \mathrm{c} ; 1$ peck, $\$ 1.35$; postpaid. paid. 1 peck, $85 \mathrm{c} ; 1$ bushel, $\$ 3.00$.

JOHNSON COUNTY WHITE DENT CORN-The ears avel age siightly longer than the Boone County White, but are about the same in diameter, grains usually long. set close on white cobs. indented. but the ears are not rougly as the Boone. Cou 49 and most of the other varieties. It shells 85 to 88 per cent, thereby indicating a medium size cob, well filled. It matures in 100 days, has good root growth and withstands storms better than most other sorts. Quart, $30 \mathrm{c} ; 4$ quarts, $65 \mathrm{c}$;
Not prepaid, 1 peck, $75 \mathrm{c} ; 1$ bushel, $\$ 2.50$.

NEW MADRID WHITE, RED COB-One of the best all-round white sorts for rich land, producing a large crop of the finest qualit of corn. The ears average about ten inches in length, of uniform This corn is a large yielder. Quart, 30c; 4 quarts, 65c; 1 pock. \$1.25. postpaid. Not prepaid, 1 peck, 65c; 1 bushel, $\$ 2.25$

ST. CHARLES WHITE, RED COB-A large, medium late, tal orowing variety, producing an abundance of fodder. The ears ar very large, both in length and circumference. The grains are long. road, deep and firmly set in a medium large cob. Quart, $30 \mathrm{c}$ 4 quarts, $65 \mathrm{c}$;
1 bushel, $\$ 2.2$

TFNNESSEE WHITE, RED COB-An extra large field corn grains long, broad and evenly lined on large red cob. The ear of this sort will run from 9 to 12 inches long and have from 18 to 20 rows. It is a rather late maturing sort, but for bottom land and main peck, $\$ 1.25$; postpaid. Not prepaid, 1 peck, $75 \mathrm{c} ; 1$ bushel, $\$ 2.50$

TENNESSEE MAMMOTH YEILOW-Ears are of a perfec shape, long and filled out to the end of the cob. The grains ar not of a tiinty type, neither are they so soft. A Southern grow large-eared yellow corn, sure to give satisfaction. Quart, 30 4 quarts, $75 \mathrm{c}$, postpaid. Not prepaid: 1 peck, $75 \mathrm{c}$; 1 bushel, $\$ 2.5$ COCKE'S PROLIFIC-One of the most satisfactory Prolific $\mathrm{V}$ a rieties, maturing fwrom 110 to 120 dass, making from two to fou good ears to the stalk. J.he ears are well filled from butt to tip. Cob white with hard flinty grains, making fine meal and Not prepaid, peck, $\$ 1.00$; bushel, $\$ 3.50$.

EARIY WHITE OR YELIOW DENT-We can supply this piety in either the White or Yellow. It is one of the best ear. corts, maturing in about 90 dars. Medium size stalk producing tw rood sized ears well filled to the tips. Quart, 30c: 4 quarts 75

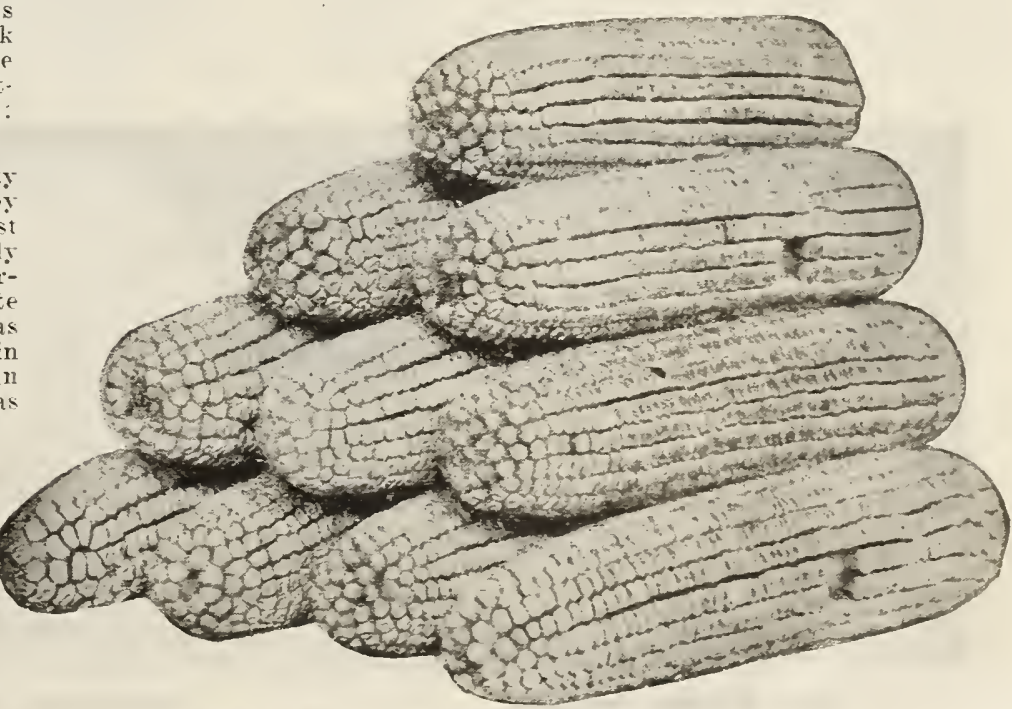

TUCKER'S BLUE RIBBON EARIY WHITE 


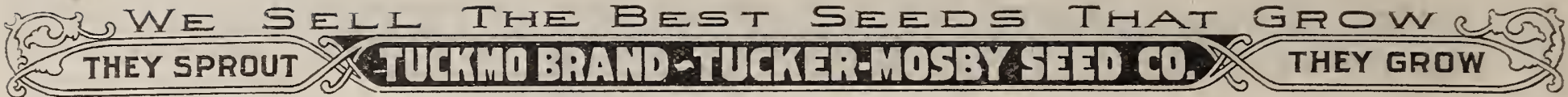

\section{SEED CORN $==$-Continued.}

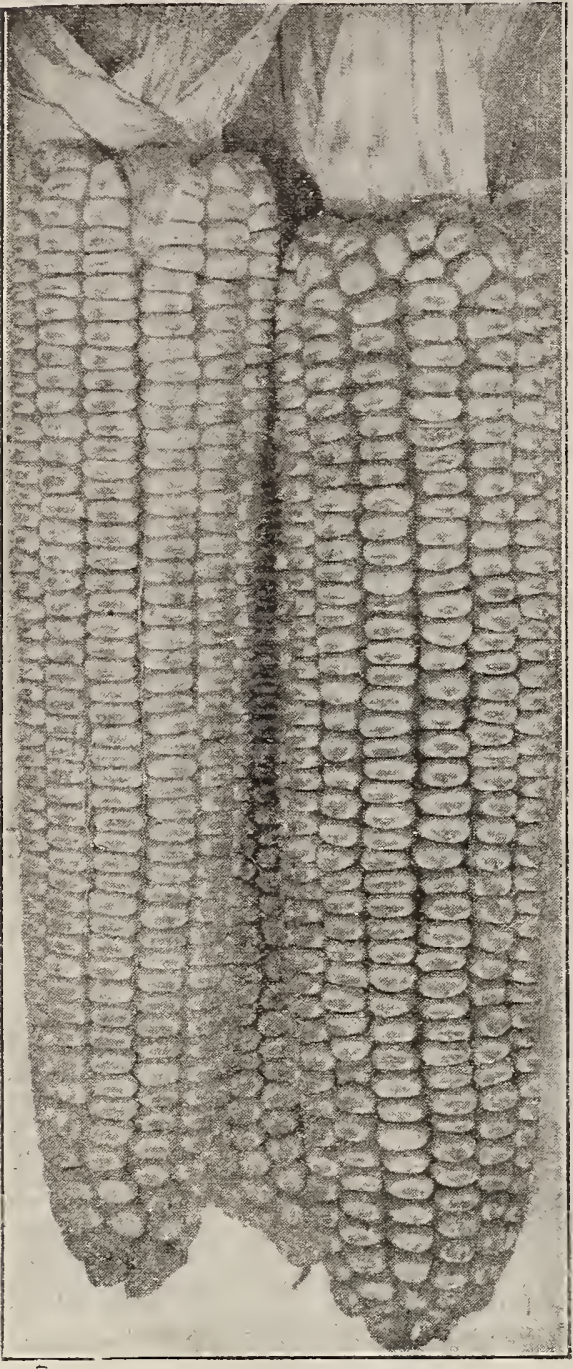

MLOSBY'S PROIIFIC

A probred white coln of very large

size and high fattening and milling qualities. It is rather a late

ariety, maturing in from 100 to 110 days. A very large, fat heavy ear, tapering only slightly from butt to tip, rounding off nicely within an inch of the top; eighteen to twenty-four rows of about fifty kernels each, carried out to the full length of the ear. Tips and butts that are exceptionally well filled out, so little waste space between the kernels that the entire surface of the cob is completely covered with practically a solid layer of grains oneiae, which, together with the dopth of grains, gives it a remarkably high selling percentage. Kernels that are of ideal shape creamy white color, moderately rough, with large germ. A very strong. igorous stalk, eight to ten feet high. Quart $30 . \cdot 4$ quarts, 75. vigorous stalk, eight to ten feet high. Quart. 30c: 4 quarts, $75 \mathrm{c}$;
1 peck, $\$ 1.25$, postpaid. Not prepaid, 1 peck, $75 \mathrm{c}$; bushel, $\$ 2.50$
MOSBY'S PROTIFIC (GrNUINE)--The most prolific corn in existence; the stalks are tall bearing three to six fine ears. abundant foliage, which renders it superior to most sorts for ensilage purposes. We unhesitatingly recommend this fine corn 1 peck, $\$ 1.50$ : postpaid. Not prepaid, 1 peck, $\$ 1.00$ : 1 bushel,

TUCKER'S MORTGAGE IIFTER-A pure white corn of and of high fattening and milling qualities. It is satisfactory results in all soils and seasons. After several vears of scientific breeding and patient selection, we have developed this variety into the largest yielding white corn known. It is of grains from one-half to three-fourths inch deep. It has a

BIOODY BUTCFER-An old standard and a mighty good variety. Description: This productive, large kerneled corn inawell formed, and averages 9 to 11 inches long, $71 / 2$ to $\delta$ inches rontain 14 to 18 rows of 14 to 18 ounces each. The ears slightly with vellow; large size, set closely on a red cob of RARIY YELIOW ROSE-This is a very large, early lellow Gorn, enormous yielder and wonderfulls vigorous in growth. The cars will average a good length and well filled from tip to but CEAMPION WHITE PEARX-A pure white early corn. ma. turing in 90 to 100 dass. Very prolific; the grain is iong and re medium sized, 16-rowed, and can be planted minch thicker than a large corn and yet bear full-sized ears. Mrakes splendid

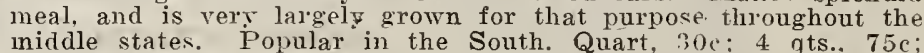
midde states. Popular in the South. Quart, 30c: 4 qts., $75 \mathrm{c}$;
1 peck, $\$ 1.25$ postpaid. Not prepaid, 1 peck, 7 isc: 1 hushel, $\$ 2.50$

IOWA SIIVIR MINE-One of the i,est early white corns, which matures in this locality in 85 days. It is pure white, grain is solid, dented and prodnces finest meal. Ears are of good length, srm metrical, well filled; grains are deep, narrow, averaging 18 to 20 rows solidly packed on the cob. Stalks 7 to 8 feet high, usually produces two good ears, which are set low on the stalk. This rorn is very popular as a main field crop in the North and West, and is the principal sort grown by many of the largest farmers. Stands up well and will probably grow more corn to the acre on thin land than any other variety. It yields enormously on heavy land. The quality is always good and has a great feeding value; the cob is white. Our stock is Iowa grown. Quart. $30 \mathrm{c}$ : 4 quarts. 75c: 1 peck, $\$ 1.25$; postpaid. Not prepaid, 1 peck, $75 \mathrm{c}$; 1 bushel, \$2.50.

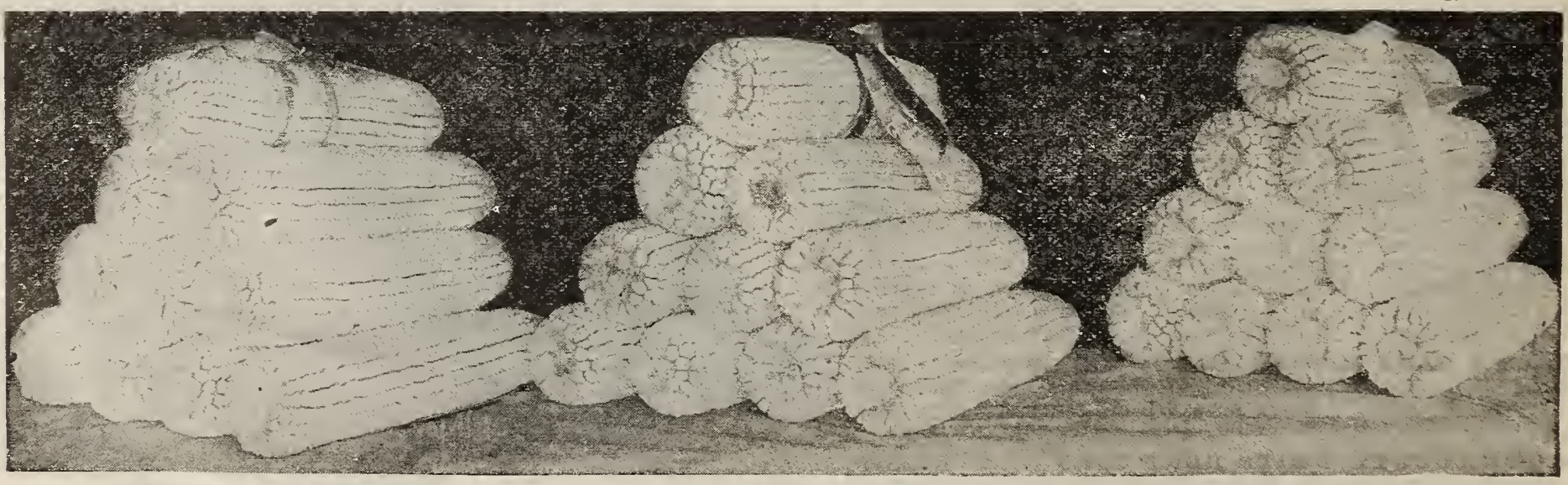




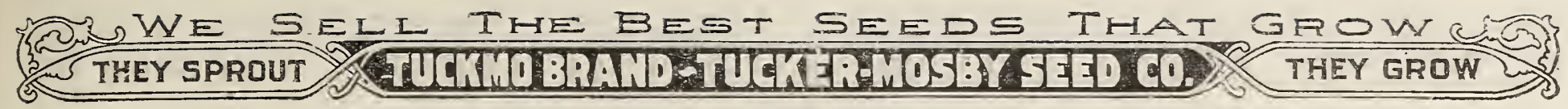

\section{SEED C OR N=:= \\ Continued \\ NOR TH CAROIINA PROIIFIC-One of the best types of ally of the prolific sorts. The ears will grow from ten to twelve inches Iong, rows twelve to sixteen; grains pure white, of moderate size; cob small. This sort fills out well and is enor- mously prolific: can figure on an average of three to five ears to the stalk. Our stocks are grown in North Carolina and will be} found pure. Quart, $35 \mathrm{c}$

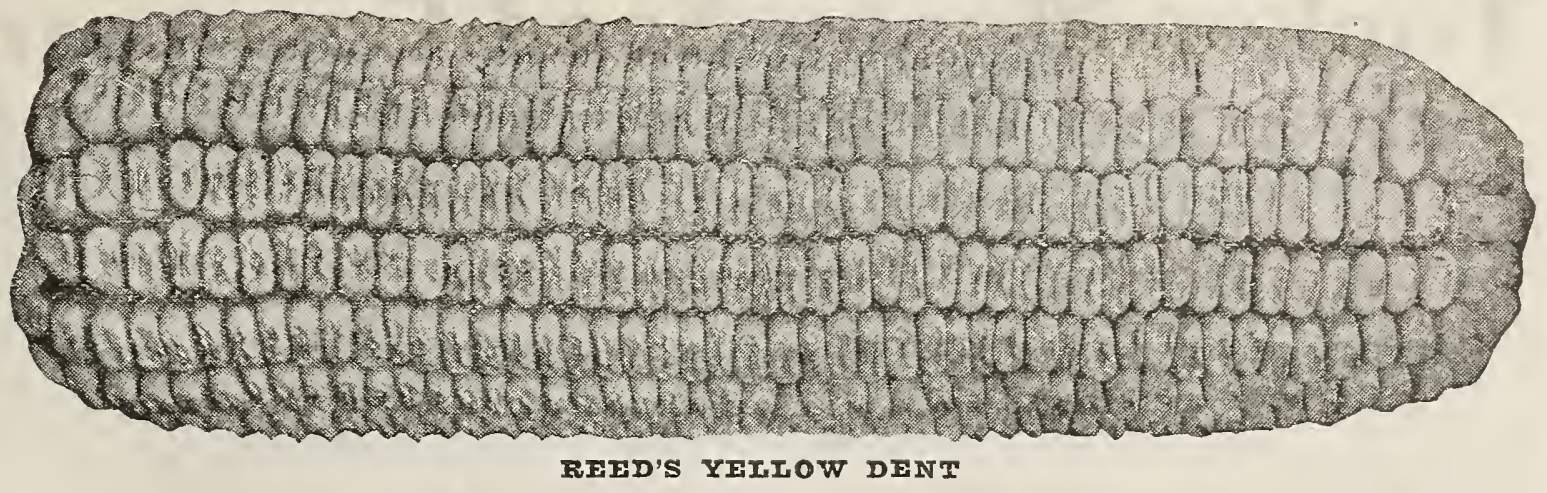

quarts, $\$ 1.00 ; 1$ peck, $\$ 1.50$, postpaid. Not prepaid. 1 peck, $\$ 1.00 ; 1$ bu. $\$ 3.50$. MEXICAN JUNE-A hardy drought-resisting white com. Ears from 7 to 10 inches long. The great value in this corn lies in its ability to make good under conditions entirely too dry for other sorts. It produces two or three good ears to the stalk and can be planted from April to July 20th in this section and make a good crop. We handle the finest quality of seed. 4 quarts, $75 \mathrm{c} ; 1$ peck, $\$ 1.25$; postpaid. Not prepaid. 1 quarts, $75 \mathrm{c}$; 1 peck, $\$ 1.25$

HICKORY IRING-100 days. The cob is no small and the grain is so large when an ear is broken in half one grain will cover the entire end of cob. Nearly all of the stalks bear two ears, and we consider it one of the best white corns grown. Does well on thin land. It ripens in from 100 to 110 dars from time of planting. Quart, 30c; 4 quarts, $75 \mathrm{c} ; 1$ peck, $\$ 1.25$; parcel post paid. By freight, not prepaid, 4 ruarts, $75 \mathrm{c} ; 1$ peck, $85 \mathrm{c} ; 1$ bushel, $\$ 3.00$.

IMPROVRD FARIY YELIOW IEAMING-One of the best early yellow field corn grown. Ears are long, with deep, small-pointed smiall grains: cob small and red. This variety matures in about 90 dass. For a general crop where a good sellow corn is wanted, nothing gives better satisfaction. It has given good results, both in the Northerm and Southern states, readils adapting itself to different soils and climates. Quart, $30 \mathrm{c} ; 4$ cuarts, $65 \mathrm{c} ; 1$ peck, $\$ 1.25$; postpaid. Not prepaid, i peck, $75 \mathrm{c} ; 1$ bushel, $\$ 2.50$.

IOWA GOID MINE-This variets has everywhere received the most cordial endorsement as one of the best and most profitable varieties. It is early, ripening in about 85 days, ears of good size, color a bright golden yellow; grain is very deep, cob sinall, and therefore dries out very quickly as soon as ripe. Seventy pounds of ear corn will make about sixty pounds of shelled corn; and in hauling to market it weighs out considerable to the wagon load than common varieties. Quart, 30c: 1 peck, $75 \mathrm{c} ; \mathrm{i}$ bushel, $\$ 2.50$.

REFD'S YEIIOW DENT-The ear is of excellent shape, nearls cylindrical, tapering gradually to tip. shape, learls cylindrical, tapering gradually to 1ip: rows, with narrow space between rows, color medium. yellow with red cob. The ear is quite solid and rather smooth; matures in about 110 dass, and rields well. Quart, 30c; 4 pecks, $75 \mathrm{c}: 1$ peck, $\$ 1.25$; postpair. Not prepaid, 1 peck, $75 \mathrm{c} ; 1$ bushel, $\$ 2.50$.

PRICES SUBJECT TO CHANGE WITHOUT INOTICE.

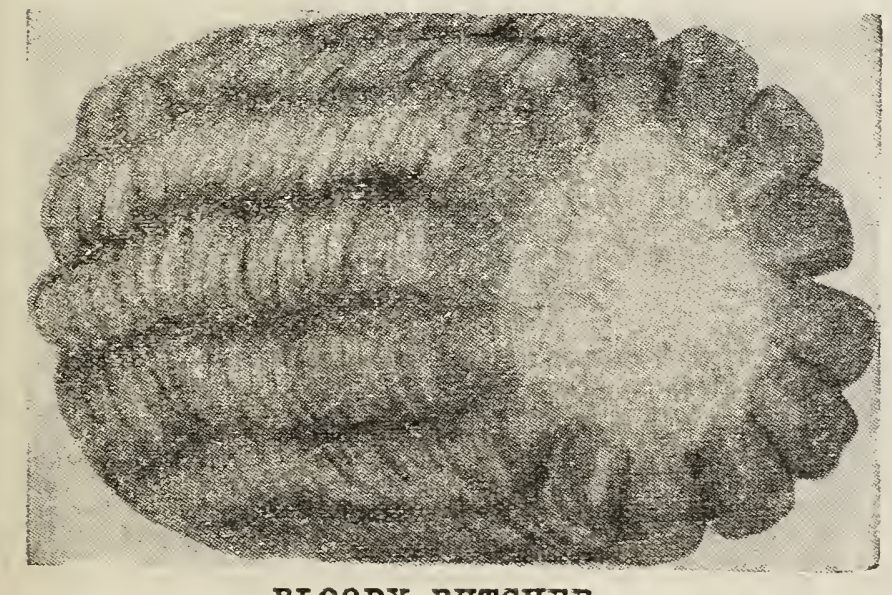

BIOODX BUTCHES

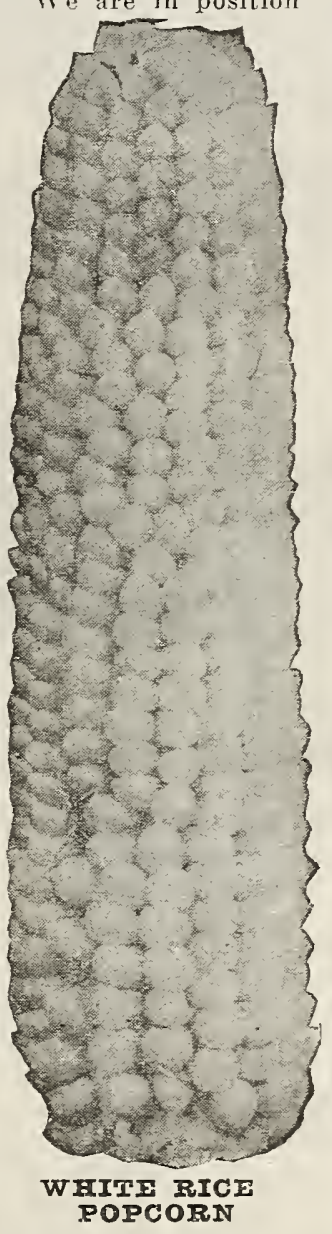

CORN

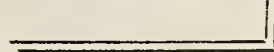

Popcorn can be raised on almost any piece of ground with a handsome pront, sometimes the income from a field of this corn being more than double that of the common field variety.

Popcorn should not be planted close to field or sweet corn as they will mix and rendev both crops worthless for market.

GOIDEIS QugrN-The large sort, stalks grow five or six feet high, producing two or three long ears on eacl
stalk, pops perfectly white. The yield of this rariety in ear corn to the acre is the equal of the larger varieties, as it can be planted much closer than larger vs.
rieties of corn. Pk., 5c; 1 1b., 25c, postpaid. express or freight, $15 \mathrm{c}$ per pound.

WHITE RICE-Widely cultivated and used more than any other sort; short ears, with long pointed kirnels express or freight, $15 c$ per

PRICIS SUBJECT TO CHANGE WITEOUT NOTICE.

\section{THE VALUE OF A CATALOGUE}

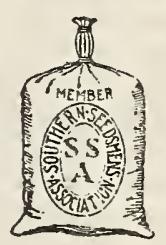

We want you to consider this book as something of more value than a mere catalog or price list. We have put much study and thought to this book as well as years of experience in the seed business, and have tried to make it a book of real worth and practical as sistance to each and everyone who tills the soil, be he lar'ge or small gardener.

If you will read our catalog carefully from beginning to end, we will guarantee that you will be well paid in doing so. If you do not learn more about the different crops and their uses, and gain information of great value to rou, we will gladly reimburse rou for rour time and trouble.

Every plant has numerous varieties. Some of these varieties are distinctly different and constantly new names are coined and givell them to mislead the purchaser into believing that he is getting something far superior or entirely different. We, however, handle only the varieties that have proven themselves to be the best obtainable and list them under their proper names. You can make no mistake by ordering your seeds from this catalogue. 


\section{Tucker-Mosby Seed Company's Re- cleaned Grass and Clover Seeds}

Sowing the Seed-All grasses and clovers used in the South can be sown in the spring; also in the fall. Have your land well prepared, pulverized and in the best of order.It is important that grass seeds be covered carefully with a light harrow not more than half an inch. Clovers and large seeds about an inch. The ground should be well rolled; the seed will then germinate beiter.

Prices named in this department are subject to important market changes. Quotations are liet and are not sulbiect to premium or discount which is offered on other seeds. Clover and Grass Seeds are constantly varying in value, and we issue a price list daily during the buying season. Please write for quotations, sending list of requirements, when in need. Orders sent us will be given benefit of lowest prices on day order is received. All prices named on Clover, Grass and Farm Seeds are f. o. b. Memphis. Where seamless cotton bags are user they will be charger for extra, 65 c each.

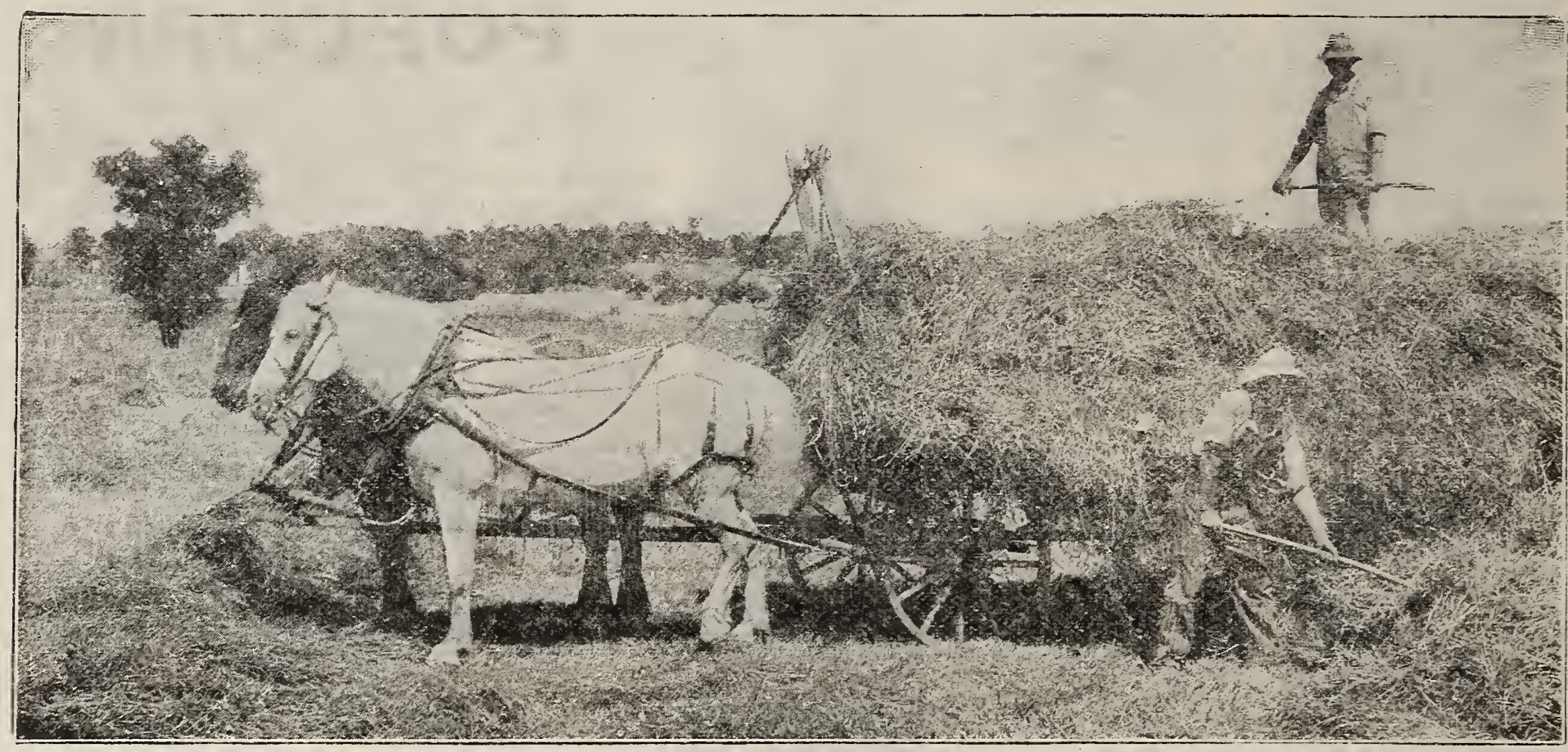

\section{HARVESTING A CROP OF TURZESTAN ALFALFA GROWN FROM TUCKMO BRAND RE-CIEANID SEED}

\section{A L F A L F A}

The Money Making Crop.

Alfalfa may be briefly described as being a deep-rooted long-lived herbaceous forage plant, belonging to the botanical family leguminose, or pod-bearing plants. Its flower's are violet, clover-shaped, and borne in compact racemes or clusters. The pods are small, slightly hairy and spirally coiled in two or three turns. The kidney-shaped seed are about one-twelfth of an inch long and several are contained in each pod. One of the most important characteristics of Alfalfa is its long tap-roots, often extending fifteen or more feet in the soil. This enables the plant to reach stores of plant food in soil which cannot be secured by the ordinary shallow-rooted field crops. This long taproot is also of great importance in sections of limited rainfall, as by this means the plant is enabled to withstand extremes of drought which would otherwise be fatal.

How to Secure and Maintain a Stand of Alfalfa.

A deep, fertile, well-drained soil, rich in lime and reasonably free from weeds. The lack of either one of these essentials is very apt to be the cause of failure. Wellrotted stable manure is the best fertilizer for Alfalfa. No other forage crops require so much lime in the soil. All of our Alfalfa Seed is 99.98 per cent pure. If you are offered Alfalfa at a low price, the percentage must be low. TUCKMO RRAND-1 lb., 40e, postpaid. BT express or freight, $1 \mathrm{lb}, 35 \mathrm{c} ; 100 \mathrm{lb}$. lots, $30 \mathrm{c}$ per pound.

DAKOTA NO. 12-Very hardy, more so than other varieties. It

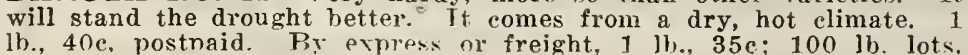
lb., 40 c. postnai

\section{L O V E R}

Treatment of Clovers.

It is absolutely necessary to inoculate the seed of Clovers, Aifalfa and Vetch. In most cases, if the inoculation is not done, the plants will grow spindling. When the seed is inoculated properly the growth is vigorous. Under average conditions inoculation will increase the growth fourfold. The most convenient way of inoculating is with Mulsford's Culture, the directions will be found on each bottle. Clovers, Alfalfa, Vetch, etc., when treated, should be sown late in the afternoon or on a cloudy day as the direct sunlight kills in about fifteen minutes the germs that the inoculation puts on the seed. When the seed is inoculated, the germs are attached to the outside of the seed. As soon as the little root starts, the germ attaches itself to the root, and a little nodule is formed. The germ on the nodule lives on the sap of the plant and brings nitrogen from the air and puts it in the plant in such shape that when the roots rot the nitrogen is added to the fertility of the soil. Without these germs, the plant can get no nitrogen from the air, consequently they are weak and the growth spindling.

AISYKE CIOVIR (TRIFOIIUM HYBRIDUM)-Also called Swedish Clover. This is being used very largely now in all sections, mainly on account of the general trouble of getting a good stand of Red Clover, though not so large a plant nor quite as vigorous. It has a lighter colored blossom, ripens two ar three weeks later. hence splendid in connection with Timothy or Red Top. Alsyke Clover produces good har, is fine for pasturing, grows better Alsyke Clover produces good hay, is fine for pasturing, grows bette as it is a perennial, lasts much longer time than Red Clover. TUCKMO BRAND-1 lb., 40c, postpaid. BY express or freight $1 \mathrm{ll}$.. 30c; $100 \mathrm{lb}$. lots, $28 \mathrm{c}$ per pound. 
ON,2,WE SELL THE BEST SEEDS THAT GROW RES

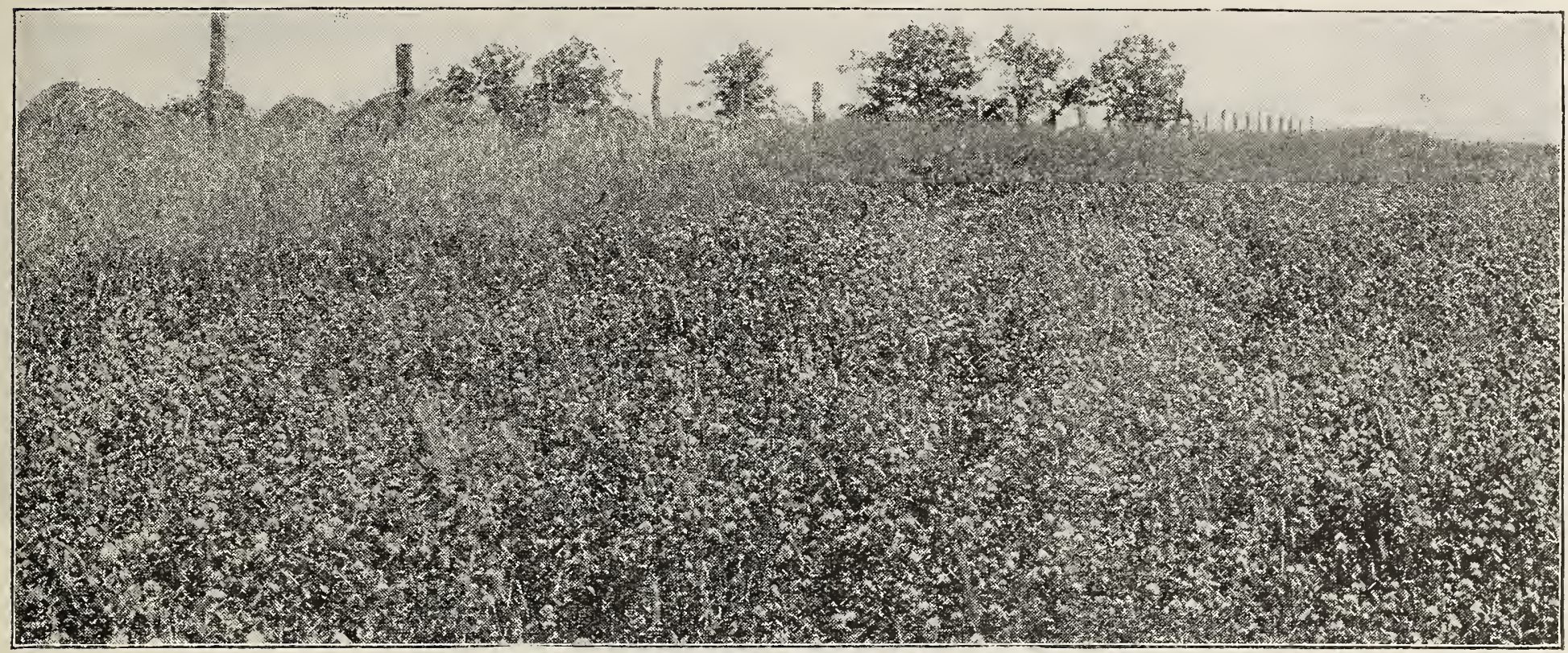

A FIEID OF TUCKER-MOSBY RED CIOVER

HUBAN SWEET CIOVER-The new annual Sweet Clover of the

White Blossom type. It is excellent for land improvement and also

of stock. Owing to its earliness and profusion of fragrant blooms it is very valuable for bee raisers. $1 \mathrm{lb}$. 75c, postpair. By express or freight $65 \mathrm{e}$ per pound.

CRIMSON CIOVRR-This Clover has been grown a great deal as a forage crop, making a splendid winter pasture. The character of foliage is very much like Red Clover, differing principally in its bloom, the Crimson being pointed and a brilliant crimson and scarlet color. It is generally planted in corn or following a small grain crop. The land should be well plowed and put in good coudition before planting. Crimson Clover is very valuable as green nanure and is especially good to sow on hill land to keep from washing. Fo improvement of the land there is nothing better, and a very profit able crop. Crimson Clover should be cut for hay when the plant bebings to bloom. Sow in late summer, fall or spring. Price, TUCKMO BRAND, the best, 11l... 35e: postpai

BUR CIOVER-Bur Clover will thrive on soils entirely too thin for cotton or corn, and will yield a good crop Inside of two years the soil will he fertile enough to grow any kind of a crop. It makes fine grazing for all kinds of stock during the winter months. "It will stand anv kind o cold weather in the South, so no danger of the crop being destroyed. It is an annual plant, so there is no danger of it becomin a pest. It requires 15 pounds of re-cleaner seed to sow an acre. We have found it excellent to sow on Bermuda grass land, as it matures its seed and dies out by the time Bernuda starts its growth. This will give ber the best time pasture. August to paid. By express or freight, 1 lb., $25 \mathrm{c}$.

JAPAN CIOVER (LESPEDEZA STRIA.TA)-Grows anywhere; is tenacious in any soil; lasts always; well known in the by scarifying surface with disc harrow. may be classed among the most valuable hay may be classed among the most valuable and pasture plants of the Southern states: is well prepared and properly seeded, Lespedeza affords a good cutting the first year an will re-seed the land, affording good crops for two or three years without any expense to the farmer except that of running a mow or over the land once or twice during the summer to keep the weeds down. Lespede is the most easily cured of any hay that can be grown in the South, as far as we know. Cutting it after the dew is off in the morning, it can be raked into windrows the same evening. The next day it should be put in shocks and allowed to remain a day or two longer, when it is hauled to rick or barn. After two weeks it is ready for the press your land, then scatter seed on top, roll the field; this will cover them enough. Sow in March or April. Seed weighs 25 ibs. per
hushel. Sow $121 / 2$ to 25 he. pere acre. Price.

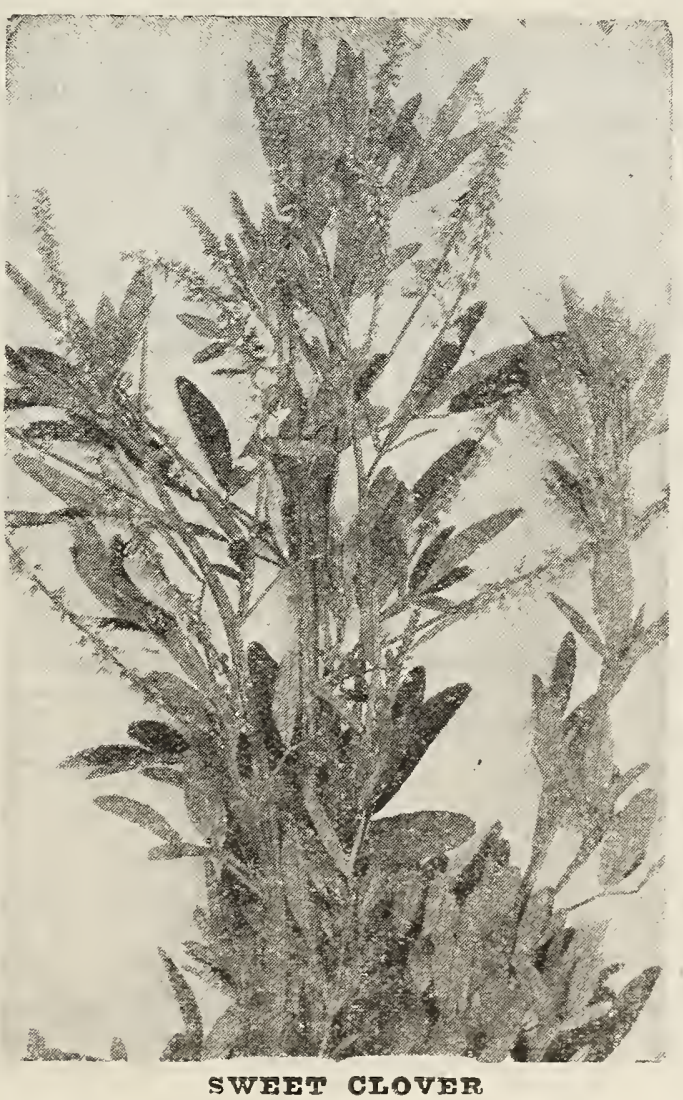

(1)

RED CLOVER (TRIFOLIUM PRATENSE)-Standard weight sixty pounds to the bushel. Red Clover is one of the most inportant tural range of adaptability does not extend far south of Tennesse and Kentucky, but found profitable in central sections of the South. shese sections can only be found through experiments. Red Clove sown by itself at least 15 to $20 \mathrm{lbs}$. of first class seed should be sown to the acre, broadcast; with winter grain or grasses, one-half of thi quantity will suffice; but, of course, it will depend largely on amount of other seed used in mixture. Soil must be reasonably good, deeply broken. well fertilized, made fine and smooth by harrowing. Seed cultivation necessary. Should be cut for hay while in bloom and care fully cured. Beside its feeding value Red Clover is a valuable ferti lizing plant, putting quantities of nitrogen in the soil through the work of bacteria on its roots. Yields 2 to 5 tons per acre. Red Clover BRAND, the express or freight, 1 lb., $30 \mathrm{c} ; 100 \mathrm{lbs}, \$ 28.00$ WHITE CLOVBR-About $10 \mathrm{lbs}$, of seed to the acre. It is very hard, standing th most other grasses have dried out. For this reason it is used a great deal for lawns. It is sown with Bermuda grass for hog pasture It does well on almost any kind of land. It It rargely in some sections for bee pas the spring. Price, TUCKMO BRAND. the frest, 1 ib 60c, postpaid. B. expres. इAPLING OR MAMMOTH CLOVER Also called Pea Vine or Engilsh Clover Similar to above except of ranker growt and blossoms three weeks later, more valu able for soiling, and by many farmers preferred for medium or poor soils, but on rich contains too much seed for horses, though good for cattle. The aftermath from Sapling Clover is fine for cattle. Use the same quantity and sow at the same time as Red Clover Price, TUCKMO BRAND, the best, $1 \mathrm{lb} ., 40 \mathrm{c}$; postpaid. By expre
freight, $1 \mathrm{lb}$., 30c; per $100 \mathrm{lbs}$., $28 \mathrm{c} \mathrm{lb}$. BOKHRA OR SWEET CIOVER-A riety of clover which, when young, resemble in growth Alfalfa, but on mature Hevelopment grows from four to six feet in height adapted to waste lands, though by many mominent farmers and stock raisers is used on good land for a crop forage. It is very vigorous in growth, standing frost and drought remarkably well, the taproots penetrating the soil very deeply, and occasionally will grow on almost any barren hillside, in bottoms, and is equally adapted to all good farming lands. Prices, TUCKMO BRAND the best, 1 lb., $30 \mathrm{c}$, postpaid. By express or 


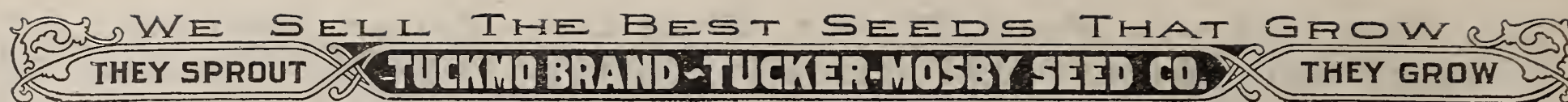

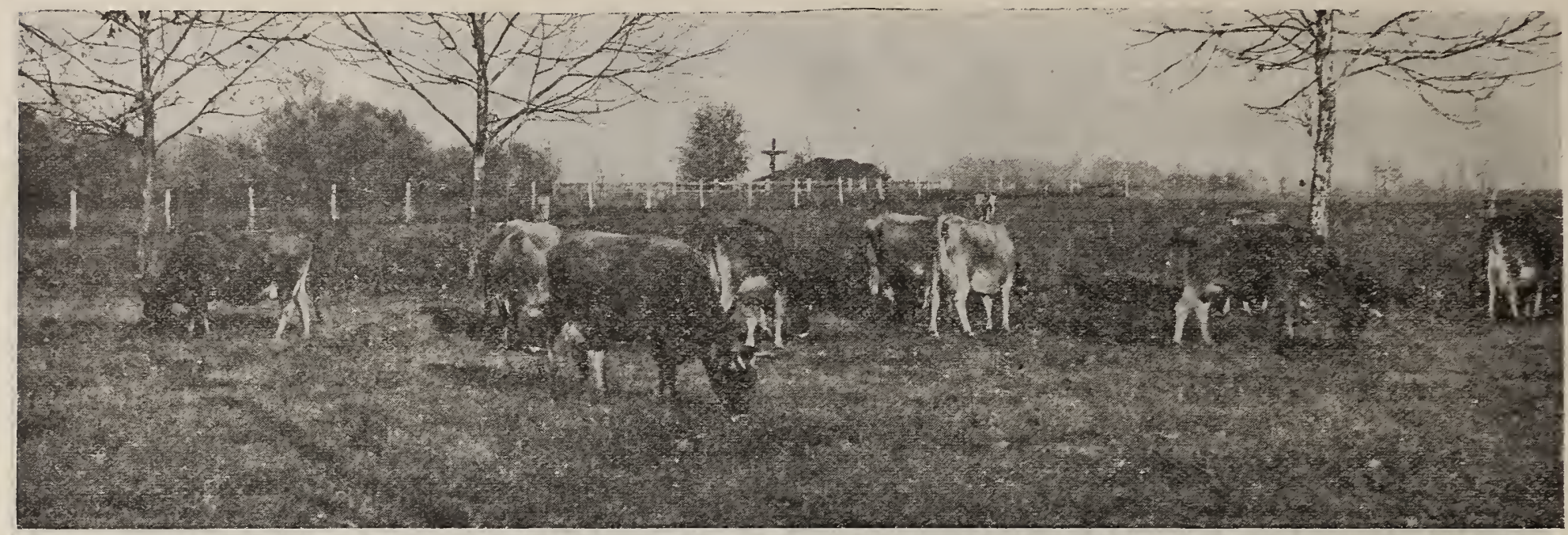

A PERMANEIT PASTURE GROWN FROM TUCKMO BRAND SEED WILI GEEATIY IMPROVE YOUR STOCK

\section{GRASS SEEDS}

\section{TUCKMO PERMANENT PASTURE AND MEADOW MIXTURES}

CHICKEN PASTURE MIXTURE

A cheap feed for chickens. By mail. 1 lb., $35 \mathrm{c}$. By freight or express, 1 lb., $30 \mathrm{c}$; 100 lb. lots, 25c per lb.

PERMANENT MEADOW MIXTURES

Will make the best quality hay, as the mixture contains such grasses as produce $a$ hay growth and mature together. We send out the No. 1 mixture when not otherwise ordered, as it is adapted to the medium or average soils. Sow about $22 \mathrm{lbs}$. (11/2 bu.) per acre; or for top seeding, 10 to $15 \mathrm{lbs}$

NO. 1-FOR MrDIUM SOILS-Contains Meadow Fescue, Perennial Rye Grass, Italian Rye, Orchard Grass, Tall Meadow Oats, Timothy, Red Clover, Alsyke, Sweet, Vermal,

NO. 2-FOR HIGH, DRY IAND, IEAVY OR CIAY SOIISContains Sheep's Fescue Alfalfa, Hard Fescue. Perennial Rye rass Mardow Fescue, T'imothy, Kentucky Blue Grass, Sweet NO. 3-FOR HIGH, DRY IAND, HEAVY OR CIAY SOIISContains much the same as above, with the addition of Orchard Grass, Crested Dogstail and Bromus.

NO. 4-FOR MOIST AND RICH SOIL OR IAND SUBJECT TO OVFRFIOW-Contains Water Meadow Grass, Meadow Fox-

tail, Perennial Rye Grass, Meadow Fescue. Red Top, Meadow Soft

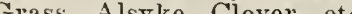

NO. 5-FOR TOP SEFDING SWAMPS, MARSHES, ETC.(Sow 10 lbs. per acre.) Contains much the same as above in different proportions.

Prices-Any of the ahove Permanent Meadow Mixtures, per lb.

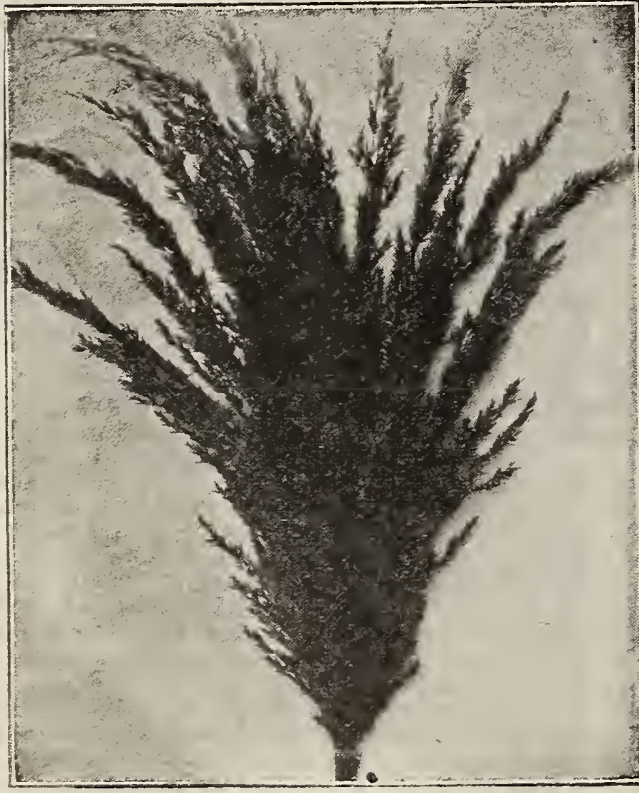

RED TOP OR FERDS GRASS
HAY AND MEADOW GRASSES ORCHARD GRASS-A valuable grass for the South, suitable either for permanent pas ture or for hay. Any soil that will grow oats will grow Orchard Grass. The soil must be thoroughly prepared, harrowed in and rolled if possible. The proper time of the year to sow Orchard Grasses, either in the early fall or spring. Sow two bushels of seed to the acre. The seed should be sown broadcast; should be cut for hay when the heads turn a light straw color. Should yield three tons per acre on good land $1 \mathrm{lb}, 30 \mathrm{c}$ postpaid. By express or freight, 1 lb., $20 \mathrm{c}$ FINGISH PERENNIAI RYE GRASSIt is a permanent grass for meadows and pastures. It will grow from 2 to $31 / 3$ feet high. It is a very quick grass. When cut in bloom it will afford a large quantity of hay. 1 lb., by mail,

TAII MPADOW OAT GRASS-A fall growing grass with flat leaves. It has proven very hardy and may be sown either in the fall or spring. It will do well on woodland pastures where it is possible to prepare the soil thoroughly. Ready to cut for hay as soon as it blooms. A good stand can be cut two or three times a season: 30 lbs, of seed to the acre. $35 \mathrm{c} ; 100$ lbs., $\$ 30.00$.

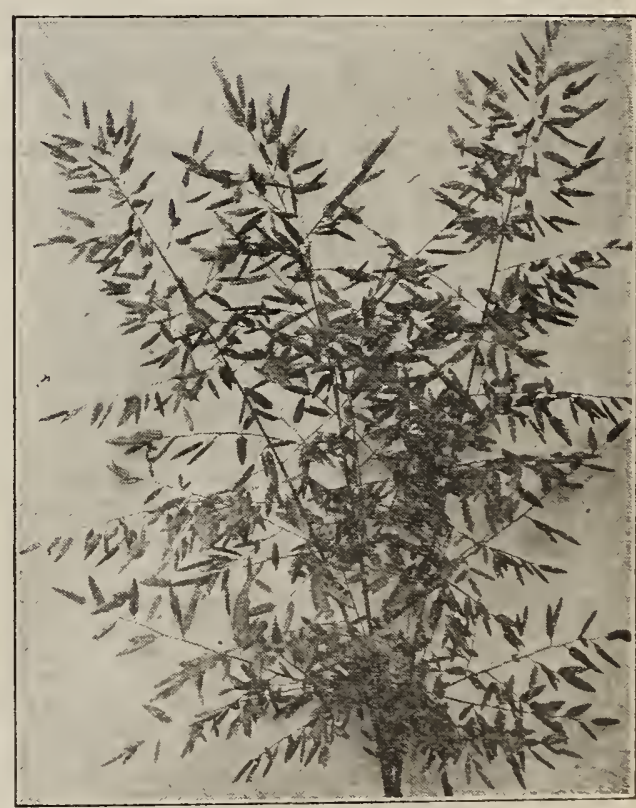

ORCIARD GRASS 


\section{TUCKMO PERMANENT PASTURE AND MEADOW MIXTURES-(Continued)}

KENTUCKY BIUI GRASS-This grass is sown with success in grass mixtures. It will do well in all sections where the land is suitable. It will do better on limestone soils. Blue Grass will do better when sown in the spring or fall as it will not stand the hot dry weather during the summer months. Sow 30 pounds of seed to dry weather during the summer months. Sow 30 pounds of seed to
the acre. It is excellent for lawns. 1 lb., $50 \mathrm{c}$, postpaid. By express or freight, $40 \mathrm{c}$ per pound.

RED TOP OR HERDS GRASS (ARGOSTIS VUIGARIS) Probably the most useful and one of the most desirable grasses in cultivation, succeeding better on more soils than any other grass in all sections of the United States. The first year Red Top grows somewhat slowly. It improves with age, however, becomes ver vigorous and spreads rapidly by neans fairly successful on hillsides and sandy foils. In low situations, even where subsols. In low situations, even where sub-
ject to overflow, produces luxuriant ject to overflow, produces luxuriant growth and attains a height from 3 to $31 / 2$ feet, and produces most excellent
hay, for which purpose cut when in bloon hay, for which purpose cut when in bloon. Furnishes excellent pasture throughou the spring, summer and rall montlis, and ripens about the same time as timothy
Price, TUCIKMO BRAND, the best, 40 per pound, postpaid. By express or freight, $30 \mathrm{c}$ per pound.

FARD FESCUE (FTSTUCA DURIUsCUIA)-Similar to Sheep's Fescue, but not so dense, and growing somewhat taller. This often will cover sandy soil under the shade of large trees where no other grass will grow. Is a desirable addition to lawn grass. Sow 30 pouncs per acre. 1 lb., 60c; 3 lbs., $\$ 1.65$, post paid. By express or freight, $50 \mathrm{c}$ per $1 \mathrm{~b}$

CARPET GRASS-Excellent for lawn or pasture purposes on coast and all sandy lands. Grows equally as well on uplands. It stays green all year. Stools heavily from one parent stalk and spreads rapidly Blades are wide and give fine forage, and, when well set, forms thick, green carpet that cannot be uprooted by any amount of grazing. Sow 7 to 10 pounds to acre broadcast. 1 lb., $40 \mathrm{c}$; 5 lbs., $\$ 2.25$, postpaid. Not prepaid, by express or freight, $1 \mathrm{lb}, 30 \mathrm{c}$

BFRIMDA GRASS-There is no grass that will stand the summer like Berwill succeed well on any kind of soil. The only objection, it dies oul

winter. No farmer should be without Bermuda pasture, as it will provide a pasture for all classes of live stock dur. ing hot, dry weather when all other grasses have failed. Care inust be exanything in the spring that would create too much shade. 1 lb., $35 \mathrm{c}$, postpaid. By express or freight, $30 \mathrm{c}$ per pound. SHEEP FESCUE (FESTUCA OV INA-Most valuable as a pasture grass
for high and dry situations, affording good grazing where other varieties burn out. We especially recommend this gras in mixtures where long droughts are liable to injure other sorts. The foliage is very fine in texture, It has a tendency to grow in tufts, hence close grazing is desirable. If sown alone use 1 to 2

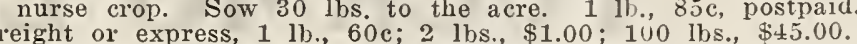
JOHNSON GRASS-While considered a pest in many parts South it is coming to be recognized as one of our most valuable hay and forage plants in places where its growth can be controlled and kept from spreading into cultivated fields. No other plants make
such enormous yields of hay. It should be cut or mowed just the seed heads begin to forn. Sow 1 bushel per acre, either in fall or spring. $\mathrm{l}$ lb., $25 \mathrm{c}$. $\mathrm{By}$ express or freight, $1 \mathrm{lb}$., $15 \mathrm{c}$.

TIMOTHY-We take great pride in our Timothy seed. We grow them for seed purposes and for that redison 'Tucker-Moshy's 'Timothy inust be the best the eartl can produce, and we are sure that our farmer friends will find that there is no Timothy seed quite so filled with life, so full of vigor, so hardy and such a tremendous producer

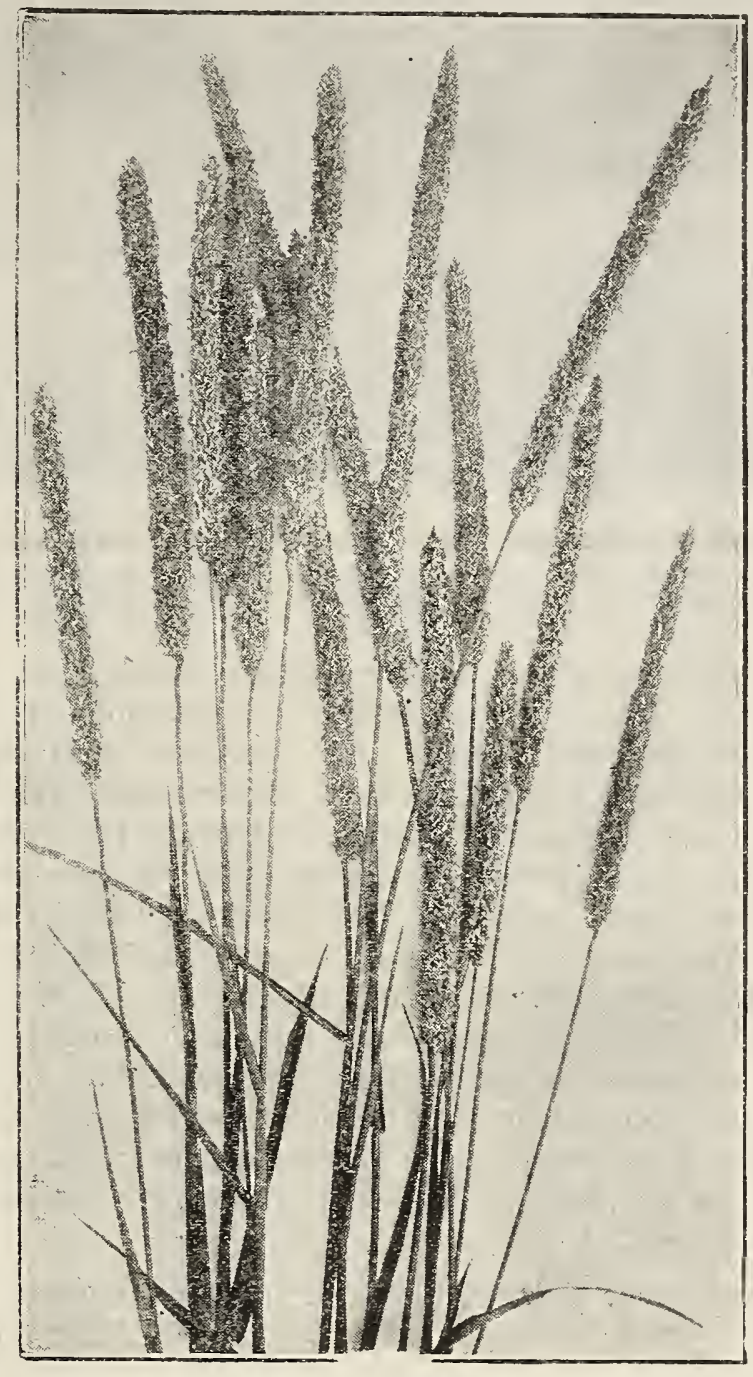

TIMOTHY

as Tucker-Mosby's. It has a wonderful Timothy is the king of all grasses. It is the most important of all liay grasse and is arlapted to a wider range of conditions than any other variety of grasses. it certainly is the nardiest of all our grasses; no other kind will stand the ex-
tremes of leat and cold b:etter than this one; no other variety equals it in aver age yields, nor does any other varioty excel it in feeding value. It luxuriates on clay and moist soil and is unsurpassed lisht sandy soils. It thowers in July and should be cut when in full bloom, as if left until lator the hay kecomes hard and coarse. The hay is very nourishing and can be preserved for a long time; it is are especially fond of it. The seed should be sorn broadcasi on a iresh seed bed and covered very lightly. Timothy can be planted in the fall or spring. It is a pounds of seed to sow an acre. Weight 45 pounds to the kushel. Price, TUCK paid. By express or freight, per pound,

CREEPING BENT GRASS, AISO CAIIFD FIORIN AND BENT GRASS--This grass is l:ighly esteemed pecially valuable for pasture and is es turf is desired. The creeping, stoloniadapted to tramping; luence it is highly esteemed for pastures, lawns and putfor polo grounds, bowling greens, etc. If Per lbone, 2 to

CANADIAN BIUE GRASS (POA CANADIAN BIUE GRASS (POA shoots its leaves very early. All grazing mals eat it greedily; cows fed on it produce a very rich milk. It is espocially relished by sheep. Its bluish green stems retain their color after the seed is poor, rocky and dry land. It should form a portion of grass and clover mixtures for such soils, but not recommendbushels per acre, or in mixtures, 10 to 12 pounds per acre. Per $1 \mathrm{~b}$. RFO 3 lbs., $\$ 1.65$, postpaid. By express or freight, per lb., 50c. feet high, with large numbers of very long, narrow and tender leaves, feet high, with large numbers of very long, narrow and tender leaves, and with lather a few branching seed spikes or slender branching
stems. It is a species that does not spread by under ground rootstalks, but produces running branches which root at the joints o nodes, thereby producing new plants. The runners are not so abund ant when the grass is growing thickly, and, therefore, does not ma. hay crop. Per pound, $75 \mathrm{c}$, postpaid. Not prepaid, per lb., 65c.

perennial grasses grown. Very hardy produ-One of the finest foliage, leaves broader than ordinary Blue Grass. It will thrive on any soil where other crops of grasses and grain will grow. The soil should be well prepared. The seed should be sown broadcast on a well prepared seed bed and slightly covered. It requires two bushels per acre. Can be sown either in fall or spring. The roots will penetrate 12 to 15 inches in the soil. A good stand of grass will yield trate 12 to 15 inches in the soil. A good stand of grass will yield
three tons of hay to the acre. 1 lb., by mail, $30 \mathrm{c}$. By express or three tons of hay to

AUSTRAIIAN WATrR GRASS-Has given splendid results in Southern climates. It is an ideal grass for dairy farmers, as it produces enormous quantities of fresh, green, juicy feed during the lottest weather; it also keeps green during the winter. The seed may

o become troublesome on account of its creeping root stocks.
xpress or freight, $1 \mathrm{lb} ., 25 \mathrm{c}$. By parcel post, $1 \mathrm{lb}$., $35 \mathrm{c}$. ITAIIAN RYE GRASS-This grass is very much like the Eng lish Rye Grass. It forms a good turf and stands dry weather very grow from two to three feet high. 1 lb., by
or freight, 1 lb., 20c; per 100 lbs., $\$ 18.00$.

PRICES SUBJECT TO CHANGE WITHOUT NOTICE.

\section{THOROUGHBRED SEED CORN}

Will give a much greater crop than ordinary seed, and pay

Planters who have

With TUCKMO BRAND SEEDS best results are assured. Order your supply 


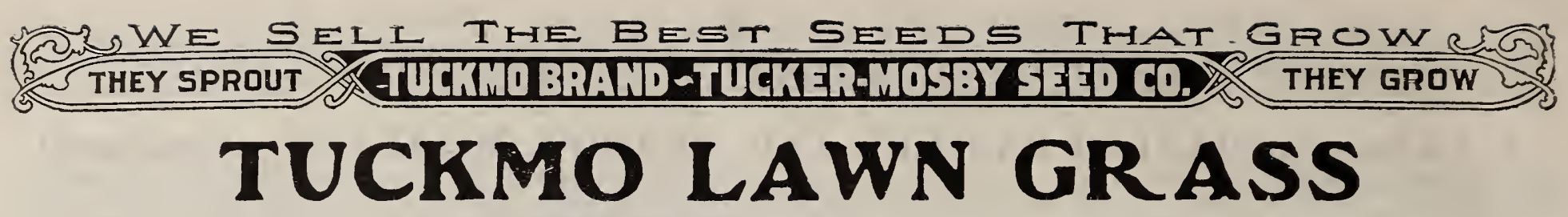

\section{HOW TO MAKE OR RENOVATE A LAWN}

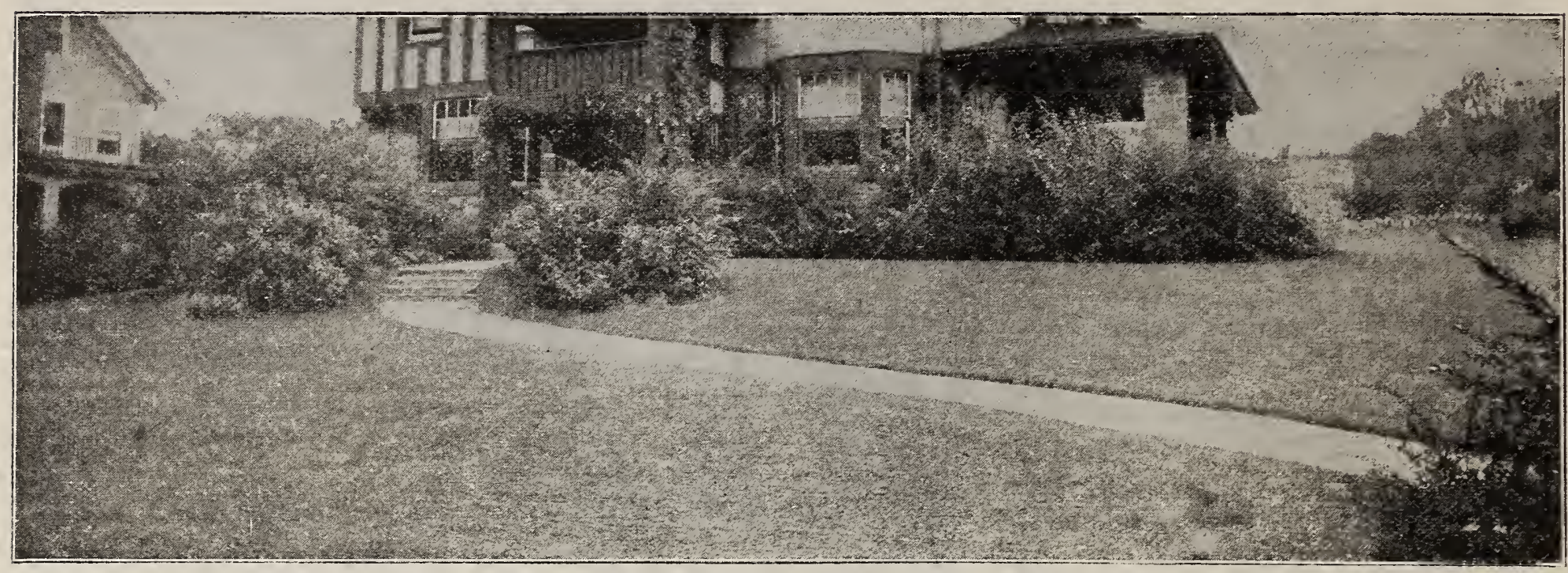

TUCKMO PERMANENT IAWN GRASS PRODUCED THIS BEAUTIFUI TURF IN A COMPARATIVILY SHORT TIME

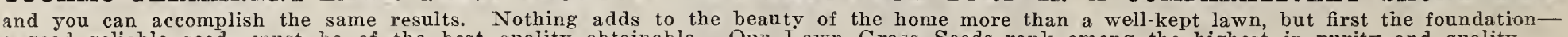
a good reliable seed-inust be of the best quality obtainable. Our I.awn Grass Seeds rank among the highest in purity and quality.

Roughen the surface of the ground with a rake before sowing. Sowing broadcast and choose a calm day for the operation so that the seed, which is very light, may lie evenly over the whole surface. When the seed is sown, rake it about lightly. All footprints must be obliterated. Small birds, especially sparrows, are very fond of grass seed, and in some places it will be necessary to devise a contrivance to outwit them. The quantity of the Special Mixture supplied by us necessary for one statute acre is about 80 pounds, or 1 pound to 50 square yards. Some sow only 60 pounds an acre, some as much as 100 pounds, but 80 pounds is the quantity we recommend to produce a fine, thick, velvety sward in a short time. If the weather proves very dry, the ground may be watered in the evening with a fine hose, both before and after germination. The grass will be ready to cut in a fortnight or three weeks; any weeds that are seen should be eradicated; an easy task now, but more difficult later on. If any bare places appear, the spots should be lightly covered with sifted soil. Employ a very sharp scythe when cutting for the first tirne; the young grass tops may at first be left upon the ground as a shelter from the sun. Cut every ten days or so and roll directly after. When the growth is sufficiently strong, a mowing machine may be used. Good attenetion should be paid to these regular mowings and rollings, as upon them success now greatly depends; the coarse grasses (if any) cannot possibly flourish under this regime, and will be eventually killed while frequently rolling, especially in moist weather, will keep the soil compact and the surface even.

No matter how small or how large your lawn is it can be made to improve the looks of your property with comparatively little work. Not only will it be a satisfaction to you, but the value of the home wil be increased; in fact, a well kept lawn often is the agency through which the sale is made. Every home owner as well as tenant should pride himself on the appearance of the grounds surrounding his home, and the first place to start the beautifying is with the lawn. To do this successfully one must not overlook the fact that pure, high quality seed is essential. A poor grade of grass seed, generally the kinds sold at corner grocery stores, are of inferior quality, often the percentage of foreign seeds far exceeding the true variety desired. In order that you may not have the misfortune of sowing a luxuriant crop of weeds buy the seed from a firm that builds their reputation upon the quality of their product. Our lawn seed is the best that can be had and will produce those beautiful turfs that attract so much attention.

\begin{abstract}
TUCKER'S SHADY IAWN GRASS SEED-Grows luxuriously under trees. Have you a lawn that is shaded by trees? Have you failed in your efforts to establish a grass patch there. If so, try a few pounds of our Shady Nook Grass Mixture. It is just what you need in order to raise a patch of fine, close, compact, velvety grass, under such conditions. Ground that has been continuously shaded by trees often becomes sour and it would be necessary be fore sowing grass seed to give it an application of air slacked lime. Apply at the rate of 25 to 30 pounds to every 500 square feet. Thoroughly stir the surface of the soil before applying the lime. Price, 50c per pound, postpaid. By express or freight, $40 \mathrm{c}$ per
\end{abstract}

TUCKMO PERMANENT LAWN GRASS-The most beautiful lawns are made with Tuckmo Lawn Grass Seed. It produces a perfect and permanent sod, luxuriant, rich and green in four to six Grass is absolutely free from weed. It is the purest, cleanest and heaviest seed ever offered. Use at the rate of 40 pounds per acre. Price, 1 lb., 40c; postpaid. By express or freight, $1 \mathrm{lb}$., $30 \mathrm{c}$ 100 lbs., $\$ 28.00$.

TUCKER'S “TERRACE SOD”" IAWN GRASS SEED-A special mixture of grasses best suited for sowing on terraces, embankments and hillsides; grasses that produce long, strong, spreading roots, thus preventing heavy rains from washing them out; that roots, thus preventing heavy rains from washing them out; that the same time produce a rich, velvety turf of fine-leaved grasses the same time produce a rich, velvety turf of fine-leaved grasses throughout the season.
freight, $30 \mathrm{c}$ per pound.

MIXTURES FOR GOIF IINKS-While there are on the market numerous ready prepared golf link mixtures of more or less value, we have found that the best results are obtained by giving individua attention to each customer and making a special mixture to irit his

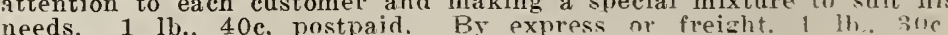
100 lbs., $\$ 28.00$.

\section{PRICES SUBJECT TO CHANGE WITHOUT NOTICE}




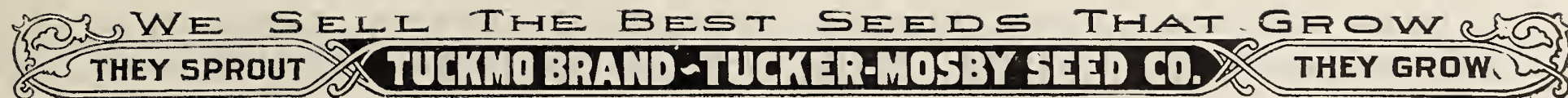

\section{MILLET}

\section{TUCKMO BRAND GRASS SEEDS-Continued}

This is one of our specialties. We have the very best and choicest Millet Seed that can be produced. Our seed is recleaned and free from foul weeds which is the cheapest seed to buy.

JAPANESE OR BARNYARD MIIIET-This is a forage plant of great value, growing in most any soil. It has been known to produce 3 to 5 tons of fodder if planted early; afte the second cutting it will afford a pasture all fall. It is relished by all classes of stock. It is called by some seedsmen Billion Dollar Grass. Requires 20 pounds of seed to sow an acre broadcast. One lb., by mail, 15c. By freight, 1 bushel (40 lbs.), $\$ 3.50$.

WESTERN MILIET-Best quality. Preferred by some to any other; does not grow so coarse. $1 \mathrm{lb} ., 15 \mathrm{c}$, postpaid. By express or freight, $5 \mathrm{c}$ per pound.

FUNGARIAN MIITET-For good low grounds or rich soil this makes even more valuable crop than the Tennessee Millet. It is considered equal in nutritious qualities to Timothy Hay $15 \mathrm{c}$, postpaid. By freight or express, $10 \mathrm{c}$ per Ib.

PEARI OR CAT TAII MILIFT-Also called Pencillaria. Makes a splendid continuous cut ting forage crop, either for green food or hay. After being cut it will stool out enormously, be coming thicker; makes a rapid growth and will afford three or four cuttings during the season. It should not be sown until about May. If sown broadcast, 20 to 30 pounds should be used, but quicker growth and nore frequent cuttings, will be obtained if sown 5 pounds per acre in drills 3 feet apart and, cultivated occasionally. One lb., 25c, postpaid. By express or freight $20 \mathrm{c}$ per pound.

SIBFRIAN OR RUSSIAN MIILET-It is claimed to be the most wonderfully productive and satisfactory forage plant, possessing in a superior degree all of the essential merits of any of the older sorts-exceeding them by far-besides many other points of excellence that disTENNESEE MIIIET (CHOICF SOUTHBRN GROWN)-False impressions regardin many crops sometimes become prevalent, and one or two erroneous ideas are fairly general It is supposed to be particularly hard on land. As a matter of fact, if cu when in bloom and before the seed forms, it is not as soil-exhausting as a crop of oats. Then its value as hay is questioned. If cut as stated and properly cured, it is equally as digestible and contains as much fiesh and muscle-producing principle as Timothy, besides more generally a fine crop of the best hay in six to eight weeks' time, and on good land yields two to two and a half tons per acre. Two crops can be seeded and grown during the summer on the sam
land. Sow broadcast one bushel per acre. Price, True Tennessee Cultirated Millet, 1 lb. $15 \mathrm{c}$, postpaid. By freight or express, $6 \mathrm{c}$ per $\mathrm{lb}$.

\section{HAIRY VETCH}

A WONDERFUI FORAGE OR PASTURE PIANT

Also called Winter Vetch. This useful plant is noted for its extreme hardiness and is valuable for forage and fertilizing purrear after vear on the same ground. The Department of A come up

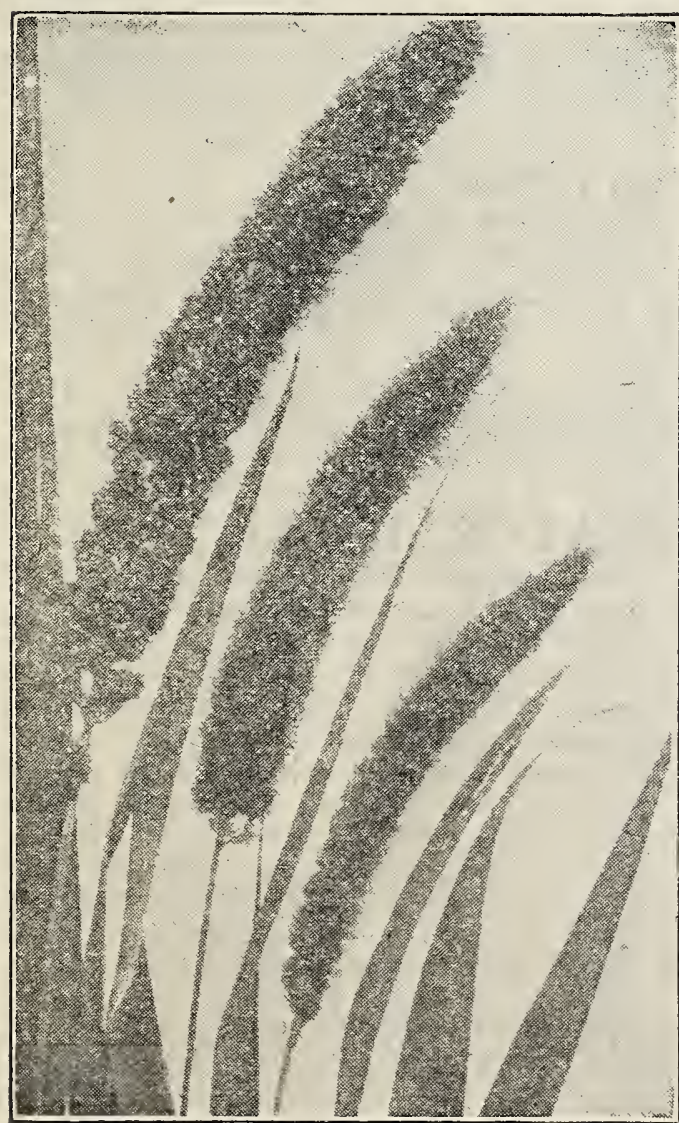

FENNESSEE GINOINE MALTET

estimates the value of an acre of Vetch plowed under equivalent to $\$ 16$ worth of commercial fertilizer. A sowing made in August or September covers the ground before winter, prevents washing dur. ing winter and early spring. It can also the som excellent hog pasture during the summer. The vield of forage varies from 10 to 15 tons per acre, equal to 3 to 4 when cured as dry hay. Sow in drills, using 30 pounds per acre. 1 lb., $40 \mathrm{c}$; postpaid. By express or freight, $30 \mathrm{c}$ per pound.

\section{JERUSALEM CORN}

Pronounced the best and surest grain crop for dry countries and seasons. It grows about three feet high, makes as high as eight heads on one stalk; grain, pure white. Five pounds will plant one acre. Postpaid, 1 lb., 25c; not prepaid, 15c per pound.

\section{SPELTZ OR EMMER}

Has proven successful in every part of the South it has been planted. It makes fine pasture and good hay if planted at the proper time. It will grow well and produce an immense crop on poor soil, and dry weather seems not to affect it. It will yield from 50 to 75 bushels of grain per acre and several tons of hay. Prepare your land like you would for oats and sow in the spring, 75 pounds per acre. It is very fine for fattening hogs, cattle, sheep and poultry. 1 lb., postpaid, 20c; by freight, 1 lb.. $15 \mathrm{c} ; 25 \mathrm{lbs}$.

\section{CHUFAS}

EARTI AIMONDS-A species of ground nut, forming abundance of small tithers on its roots. The plant resembles some green forage grass. They are easily harvested June in rows chickens and very valuable fattening for both. Plant from March to deep. They will mature in September or October. 1. lb., postpaid. 25c: 1 peck, $\$ 1.75$ 1 bushel, $\$ 6.00$.

\section{GIANT BEGGAR WEED}

This is another valuable leguminous for a plant, brow Florida, also other states now, for each year its value is better known, not only for fertilizing purposes, but for producing. hay as well as green forage. This plant will ubsist on very thin, sandy land, attaining a marvelous growth where no other vegetation seems to thrive. This is due, of course, to the plant's ability to utilize the free nitrogen of the atmosphere through the work of blant has renovated and is bringing into cultivation thousands of acres of land in Florida that heretofore It may be sown broadcast, like millet, or may be planted in drills. It will usually grow to the height of two or three feet and if put on good soil grow even much higher. Ton to fifteen pounds of seed are usually sown to the acre. Beggar Weed can be used to to fifteen pounds of seed are usually sown to the acre. Beggar Weed can be used to Beggar weed will afford splendid pasturage for hogs. cows, horses and other live stock, by. which it is much relished and very fattening. It produces excellent has, but where this is the purpose it is of course necessary to sow in a situation where the hay can be
cut. Write for price of seed in nuantity. Price of seed. 1 lb. 50c postpaid. $\mathrm{By}$ express or freight, $40 \mathrm{c}$ per pound. 


\section{TUCKMO BRAND GRASS SEEDS-Continued TEOSINTE}

RENAI IUXURIOUS-Yields excellent forage. The plant grows from 10 to 12 feet high, but should be cut before it attains this size. so as to stimulate the stooling habit. Single seeds have produced from 20 to 40 stalks, thickly set with leaves. The forage is rich and tender and eaten by horses as well as cattle and sheep. The soil best suited for Teosinte is anj soil that will produce a good corn crop. Plant in hills, three to four feet apart each way two to three seed to the hill, three to four pounds of seed to the acre. $10 \mathrm{oz}, 15 \mathrm{c} ; 1 / 4 \mathrm{lb} . .35 \mathrm{c} ; 1 \mathrm{lb} . . \$ 1.00 ; 3 \mathrm{lbs} ., \$ 2.70$, post. paid. By express or freight, $75 \mathrm{c}$ per pound.

\section{TIMOTHY AND CLOVERS MIXED}

A FINE TIMOTHY AND CIOVER MIXTURE-The operating of the farm is now a science. Every energy is devoted to securing better results. Observant farmers have long realized that Tinothy Hay with a slight mixture of Clover in it, aside from being a rare treat for stock, gives a much larger quantity of hay than Timothy grown

Alsyke, being a legume. instills increased growth to the timothy, giving a much larger tonnage of timothy than if sown alone, which, with the additional tonnage of Alsyke hay, is all velvet to the farmer.

The two types are peculiarly similar in many respects. They do equally well on the same soil; seem to hare the same range of adaptability to climate and singularly blessed in ripening their seed at the same time. By express or fright, 1 lb., $25 \mathrm{c}$ $15 \mathrm{lbs} . \$ 3.30 ; 100 \mathrm{lbs} . \$ 20.00$. B5 parcel post, $1 \mathrm{lb}$. $\$ 30 \mathrm{c}$.

\section{SORGHUM}

Sorghum is planted for feeding stock during the spring and early summer. For this purpose it should be sown as early in the spring as possible in drills about two to three feet apart, one peck per acre. It makes excellent green forder. As a forage plant for early cutting to be fed to stock, we do not think that anything is equal to it. Plant at any time from April to last of July in rows three feet apart, six to ten seeds, 12 to 18 inches apart in row, or drill lightly; can be sown broadcast; 1 bushel per acre for hav.

EARIY AMIBER-The leading and most popular variety. It is the earliest sort and makes the finest hav, green or cured, which is relished by all stock. No farmer can make a mistake by selecting this variety for green feed and silage purposes. Also makes syrup of excellent quality. Prices, postpaid. lb., 20c; not prepaid, 61/2 c per pound.

BARIY ORANGE-With taller and heavier stalks than the Early is not as early as the Amber but is a very good producer. It is con-

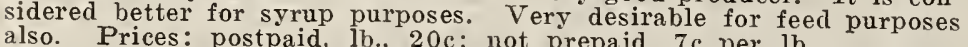
RED TOP OR STMAC CAMT This duces an immense quantity of feed. Fine for silage or green feed. duces an immense quantity of feed. Fine for silage or green feed.
and is also excellent for hay. Prices: Postpaid, lb., $20 \mathrm{c}$; not pre-
paid. $7 \mathrm{c}$ per lb.

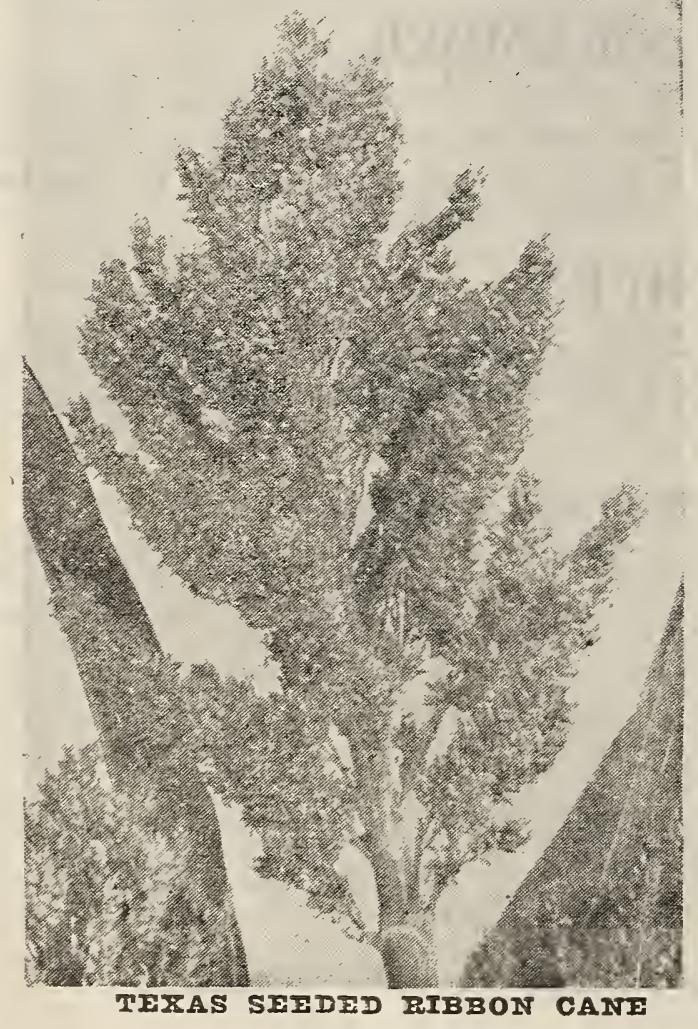

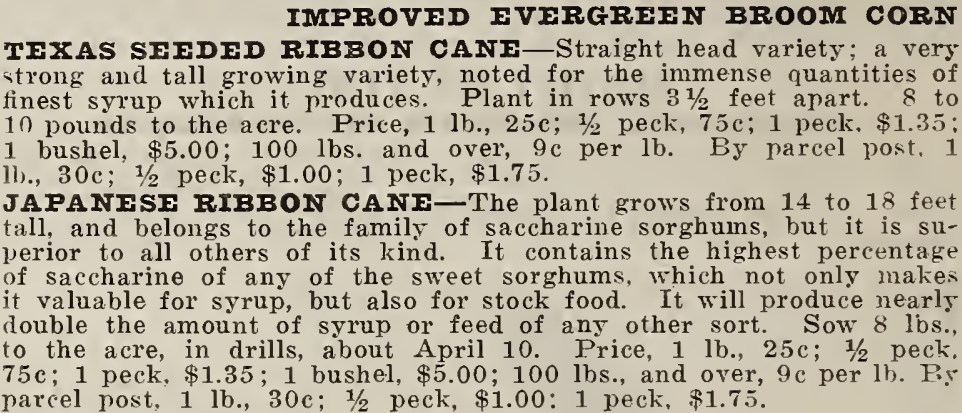

\section{BROOM CORN}

Broom Corn will succed iu any good corn soil and will make a crop with litte rain. Besides the brush it will produce a large vield of grain equal in feeding value to oats. Six pounds of seed are required for an acre when drilled in rows three feet apart. IMPROVAD EVRRGREFN-A favorite in all sections. Grows to a good length, and if cut at the proper time retains a good color. 1 lb., 20c, postpaid. By express or freight, 1 lb., 15c: 1 peck ( $\left.12 \frac{1 / 2}{\mathrm{lbs}}\right), \$ 1.00 ; 1$ bushel, (50 lbs.), $\$ 3.00$ : 100 lbs.. and DWARF OTTATOMA-This variety grows onl 3 to 4 feet high and is much easier handled than the tall growing sorts. The brush is straight smooth and of good quality. 1 b., $20 \mathrm{c}$, postpaid. By express or freight, 1 pech $\left(12 \frac{1}{2}\right.$ lbs. $), \$ 1.00: 1 \mathrm{bu}$. (50 lbs. ), 1 b., $20 \mathrm{c}$, postpaid. By express or fre
$\$ 3.00$. 100 lbs. and over, $51 / 2 \mathrm{c}$ per $1 \mathrm{~b}$.

\section{EGYPTIAN WHEAT OR SHALLU}

The great drought resister and grain producer. Belongs to the Sorghum family and should be planted like cane or milo, either for grain or hay. Broadcast it makes from four to eight tons to the acre. In drills, it yields 35 to 50 bushels of grain per acre. The grain is small and white inside and has a light hull. The heads are large and heavy, the grain hanging on one side. The grain makes better bread than maize. All stock eat it and do well on it. It makes the best poultry food. The plant grows from five to seven feet tall, and produces more and better fodder than cane. Stools out from the root, making five to six stalks, makes excellent fodder. It will stand more wet and dry weather than maize or cane. We don't believe there is such a thing as failure with it. Plant in drills three feet apart, using from $11 / 2$ to 2 bushels. Price, 1 lb., 15c; 100 lbs., per lb., 10c. By parcel post, 1 lb., 25c; 10 lbs., $\$ 1.50$.

\section{WHITE KAFFIR CORN}

A most excellent fodder plant. Grows 5 to 6 feet high, making a straight, upright growth. The stem or stalk bears numerous wide leaves. The stalks keep green and are brittle and juicy, making excellent fodder, either green or dried. Fire pounds of postpaid. BF freight or express, not prepaid. $1 \mathrm{lb}, 10 \mathrm{c} ; 100 \mathrm{lb}$. lots, $61 / 2 \mathrm{c}$ per pound. 


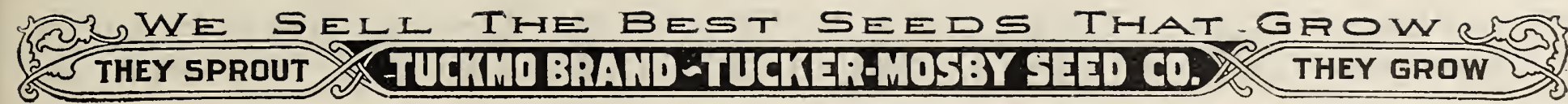

\section{TUCKER'S EARLY SPRING WHEAT}

Early and prolific, medium size heads, well filled, plump kelnels, stool heavily and is one of the finest milling varieties. It has been grown

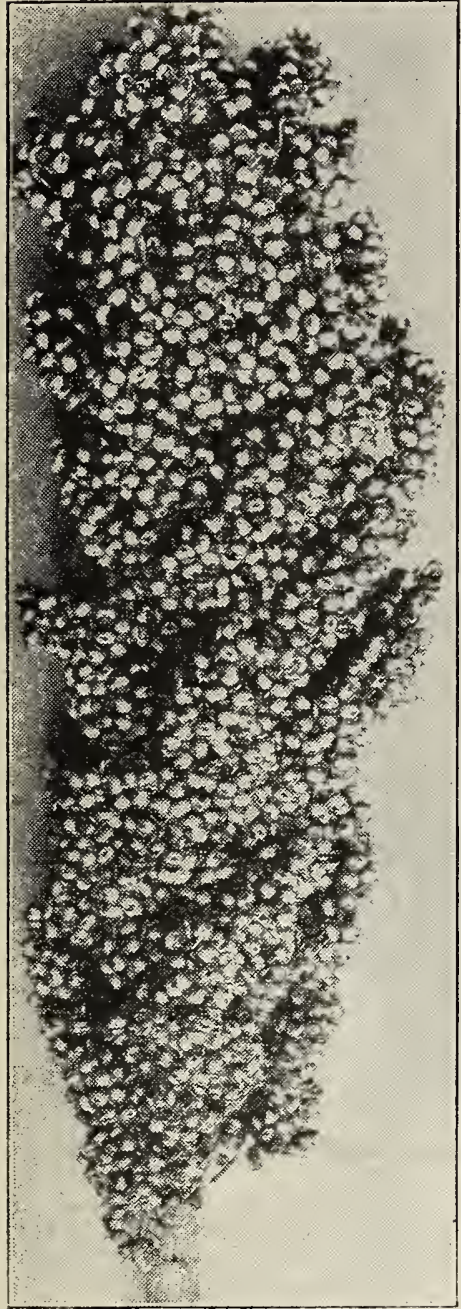

FETERTTA for years in the extreme North, which as sures its hardiness in all sections of the country. One pound, 25c, postpaid. By freight, 1 bushel, $\$ 2.00$.

\section{FETERITA}

The Latest Introduction and the Very Best of the Non-Saccharine Sorghums.

Feterita has four great features, as follows: Drought resister, branches from the root, great yielder, ranging from 40 to 80 bushels per acre; earliness, being easily 20 to 35 days earlier than Kaffir Corn, Milo or any other of the Non-Saccharine Sorghums.

During the past dry season Feterita demonstrated its ability to withstand the extreme hot, dry weather, head and shoulders above all other branches of its family. Feterita made big yields in the same fields, where side by side with Kaffir Corn or Milo, the two latter varieties made an almost total failure.

Feterita matures from 20 to 25 days earlier, thus insuring a matured crop ahead of all danger of early frosts.

No variety of seed of any kind planted in the middle west has ever sprung so suddenly into popular favor. The seeds are almost round, white in color, while the heads are extra large in size, and grow upright on the stalk. Feterita is strictly a dry climate grain and too much must not be expected of it, if planted on wet ground or in sections where there is abundant rainfall.

Reports from the semi-arid districts of the West place Feterita at the very top of the list as a grain producer, fodder vielder and sure cropper.

Feterita should be drilled in rows, about the same width apart as corn using 5 to 7 pounds of seed per acre. Price, 1 lb., 20c; 3 lbs., 50c; postpaid. By express or freight, $1 \mathrm{lb}$., $10 \mathrm{c} ; 100 \mathrm{lb}$. lots., per lb., $61 / 2 \mathrm{c}$.

\section{DWARF ESSEX RAPE}

One of the most satisfactory quick-growing crops for cattle, sheep and hogs, affording in from six to eight weeks from sowing, excellent pasture, besides being splendid soil improver. Rape has a high feeding value. It is excellent for fattening sheep and swine, produces an abundant flow of milk in cows, and is the ideal pasture for weaning lambs. Can be sown broadcast in the spring at the rate of six to eight pounds per acre, or in the fall four to five lbs. If sown between corn, three to four pounds is sufficient. Spring seeding is possibly the best as it grows luxuriantly all summer, affording pasture from spring until winter, going to seed the following spring. If sown after wheat or oats the ground should be disked and the seed lightly harrowed in. Price 25c per lb., postpaid. By express or freight, 15c per pound; $100 \mathrm{lb}$. lots and over, 12c lb.

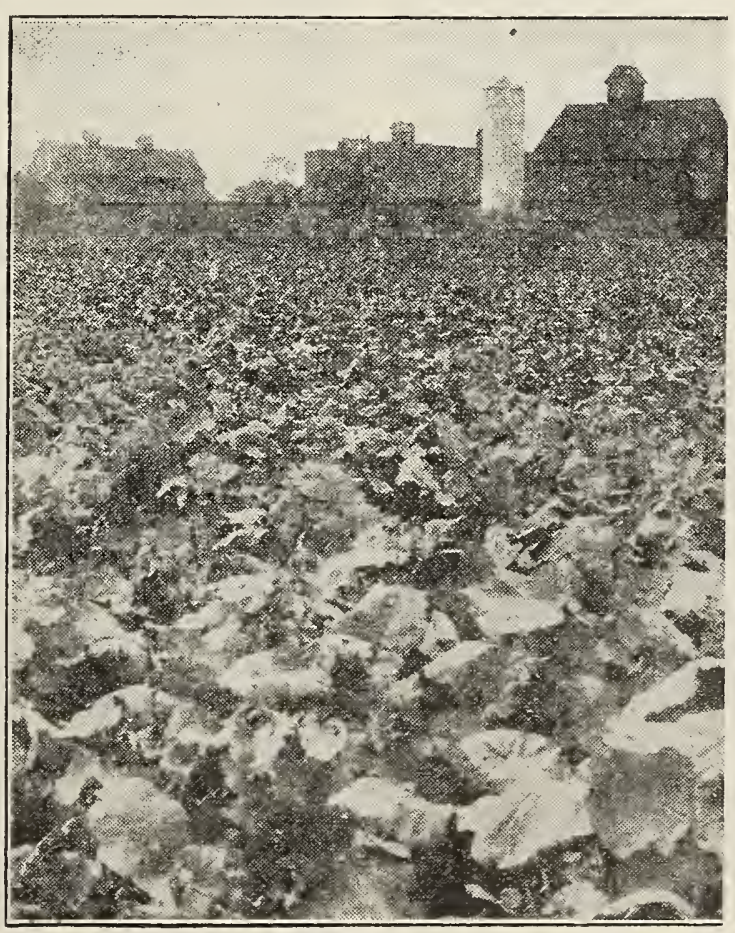

DWARF FSSFX RAPE

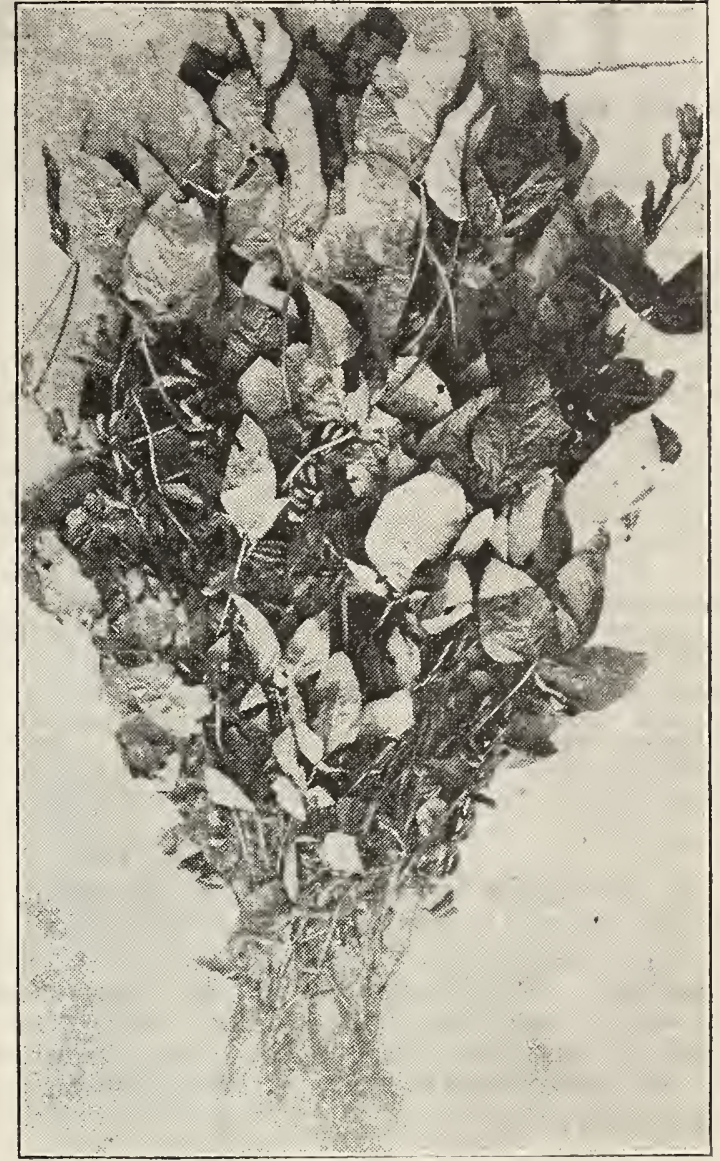

SOY OR SOJA BEANS

\section{MILO MAIZE}

This is a plant very similar in manner of growth to Kaffir Corn, but is preferred by many growers, who claim that it produces more grain per acre and better quality of forage than any of the non-saccharine sorghums. 1 $1 \mathrm{~b} . .20 \mathrm{c} ; 3 \mathrm{lbs} ., 50 \mathrm{c}$, postpaid. tb. lots at $61 / 2 \mathrm{c}$ per pound

\section{MUNG BEAN}

\section{SOY OR SOJA BEANS}

\section{As a feed for live stock, whether trown} for the hay or the beans, threshed to feer with some other grains, its value cannot equal to clover. An a fertilizer, it is grow Sor Beans. The plant is not mo lested by insects of any kind, and heat and
drought do not affect it. The yield of drought do not affect it. The yield of beans is from 20 to 30 bushels per acre. four fed to milch cows, using three or other feed the milk yield will be doubled. When grown for the beans, they should be drilled in rows and cultivated like corn, using about one-third bushel of seed per acre. For hay they should be sown thick

MAMMOTH YEILOW-One of the largest known varieties of Soy Beans: produces a world of foliage and beans. One of the best for this climate. Price, postpaid. quart, 30c. By express or freight, 1 peck 


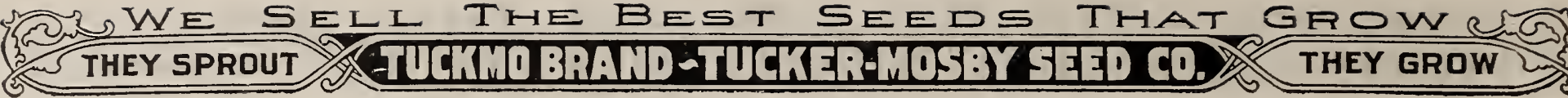 TUCKER-MOSBY SEED OATS}

BURT OATS--The Burt Oat is an extremely early variety, pro ducing an abundance of straw of good length. It is the best poor land oat known, also the safest and earliest to plant in the spring. The grain is small, light, slim, and under favorable weather conhave beard and are frequently borne in clusters of two. The genuin before Rust Proof. No less than two bushels of Burt Oats shouid be used in seeding an acre, and where it is to be made in to hay three bushels will be found profitable. The standard weight of oats 32 pounds to a bushel. Bushel, 90c.

APPIER OATS-This is a Southern grown type of heavy red rust-proof oats, mostly bearded. It is the most resistant variety to rust that is grown in the South. When grown on good land the rain is very large, red in color, often containing more or less black grains, and will frequently weigh as much as thirty-six to thirtyeight pounds to the measured bushel. It is a tremendous yielde of grain. Two and a half bushels to the acre Price, 1 bushel. 10-bushel lot, $\$ 8.50$.

WINTER TURF OATS-This oat is unsuited for spring planting. They are best planteil in the fall and will furnish excellent winter and spring pasture. One bushel, $\$ 1.25 ; 10$ bushels and over, $\$ 11.50$ RED RUST PROOF OATS-These oats are very popular through out the South, especially on the light, sandy soils of the coast legion. They are also preferrea for low grounds or in situations where other oats are much inclined to rust. They make a yield of fine, heavy

\section{BUCKWHEAT}

A desirable and profitable crop for spring sowing. It is easily grown, makes a splendid flower food for bees, and a large yield of grain. It is prized as a poultry feed, being regarded as a stimulant to egg production, and when ground is profitably fed to hogs and other stock. It is also an excellent fertilizer and soil improver. Should be turned under like cow peas. Plant one bushel to the acre.

JAPANESE-Makes a splendid flower food for bees and a large yield of grain. Sow from $1 / 2$ to $3 / 4$ bushels per acre. By mail SIIVIR HUIL-A superior variety. By mail, $1 \mathrm{lb}$, postpaid, $25 \mathrm{c}$. Not prepaid, pound, 15c: 1 peck, $85 \mathrm{c} ; 1$ bushel, $\$ 3 . n$

\section{VELVET BEANS}

A Famous Forage and Soil Improving Plant.

Velvet Beans are pronounced by experienced agriculturists of areatest value. The vines and beans inake the most nutritious feer, universally popular. The vines and roots are rich in nitrogen, makin a most valuable soil improving crop, and they produce enormous crops for forage or soil improving. They do not mature seeds ex. in rows 5 to 6 feet apart, dropping one or two beans every foot.

OSCEOIA VEIVET BEAN-A wonderful variety of Velvet Beans that has become very popular throughout the Southern States, and we predict that it will very shortly become the most largely

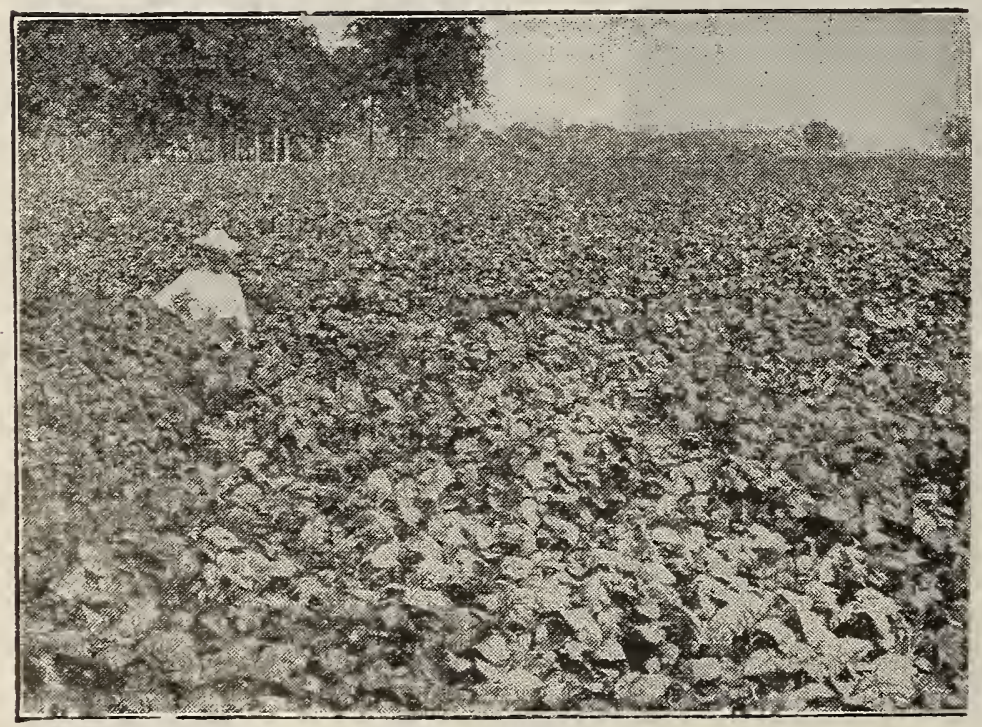

A FIEID OF VEIVET BEANS

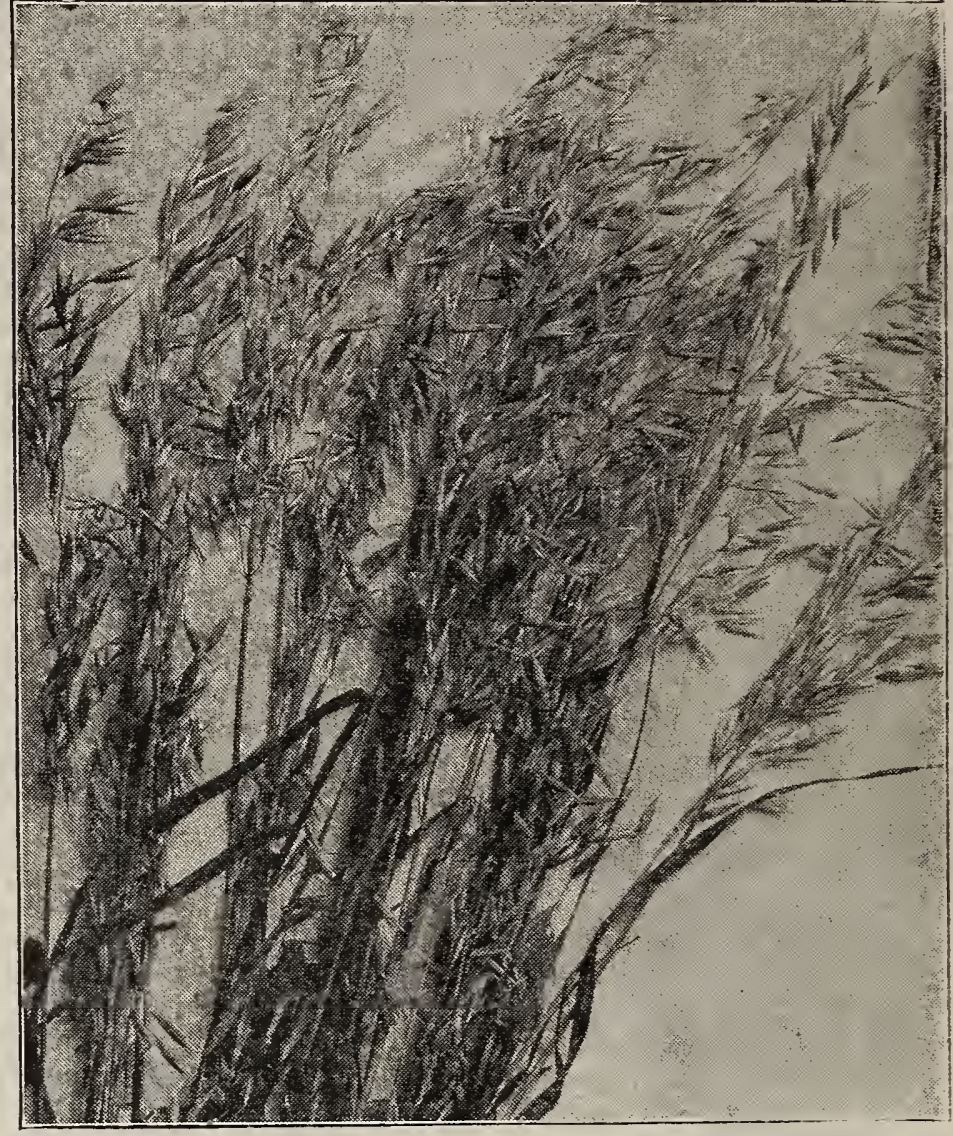

RED RUST PROOF OATS

planted of all varioties. It has been pronounced as the greatest of all velvet beans by most practical farmers. A hybrid of the 100-day Farly Speckle and the Yokohama. It is larger than the Early Speckle, more productive and earlier. Produces as much foliage, but is free of the itching fuzz that makes other Velvet Beans so dis is free of the picked very much agreeable to pick. Costs less to pick and can be picked and largely easier. Commences to get ripe about about October 1st, and this ripens before the 15th. The leaves shed about makes the bean pod and corn gathering easy. Blooms mostly purple. The beans are speckled like the 100-day, but twice the size, producing a pod as large as the "Chinese. Pods are five inches inany two bunches to the joint. It is the best varietr for fertilizer, crushing, or grinding. It is the best vielder of seed of any variety. Lb. postpaid. 25c. By express or freight, peck, $75 \mathrm{c}$; bushel, $\$ 2.50$.

FXTRA FARIY SPECKIE VEIVET BEAN-An extra early Velvet Bean that is largely planted throughout the South, and extreinely popular. It is one of the quickest-growing and earliest maturing of the Velvet Beans and is well adapted for growing in districts further North than Velvet Beans ordinarily have been grown. You can plant these beans during May and June, and they will mature in time for fall planting, a quick September grazer, or for turning under to take advantage of its wonderful soil-improving features. It is one of the most prolific of all sorts, and a depend. able variety for you to plant. There is nothing that equals our ale of this variety, being absolutely new-crop (not carried-over. seed of this variety, being absolutely new-crop. Pound, $25 \mathrm{c}$. post poor germinating seed) seed of high germination. Pound,

\section{UPLAND RICE}

You can grow rice just as easily on uplands as on flooded low Any ground having a reasonable amount of moisture will produce a good crop. Prepare the land and cultivate as for corn, except the rows are only 22 inches apart, so that one furrow in each middle, with an 18-inch sweep, usually suffices for a working, and the hills just far enough so it can be hoed. Plant as earls in April as you can. Drop 15 to 20 seeds in each hill and leave all that come up. Cultivate for moisture and to keep down grass and weeds until the rice begins to head. It usually ripens last $\mathrm{Re}$ August or early in September. The colors $44 \mathrm{lbs}$. to the husliel. Prices: Postpaid, 1b, 25c. Not prepaid, lh.. 15c: 1 peck. $\$ 1.25$ : hushel, $\$ 4.00$ 


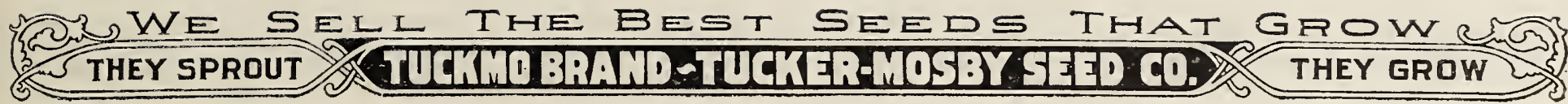

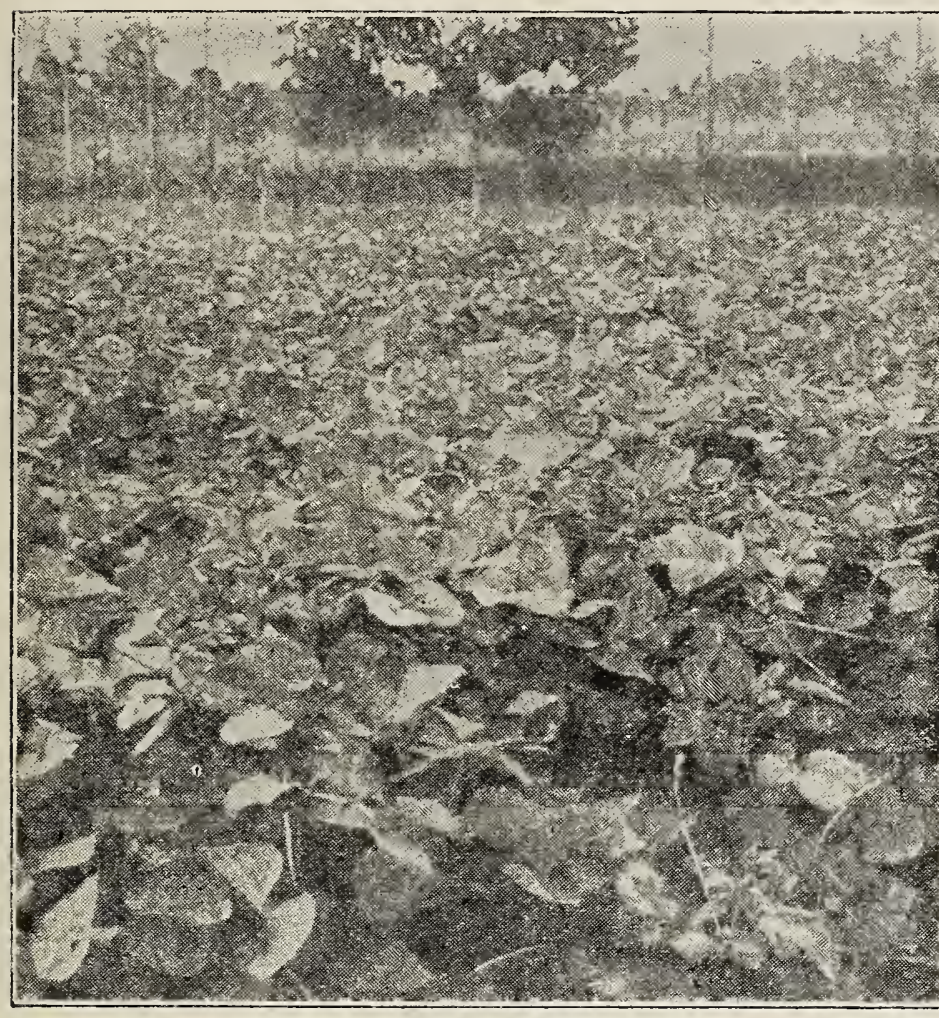

A CROP OF COW PEAS FROM TUCKMO BRAND SEEDS COW OR STOCK PEAS

Market prices on Cow Peas change often. Write for price on bushel or over when ready to buy.

The following prices are subject to market fluctuations:

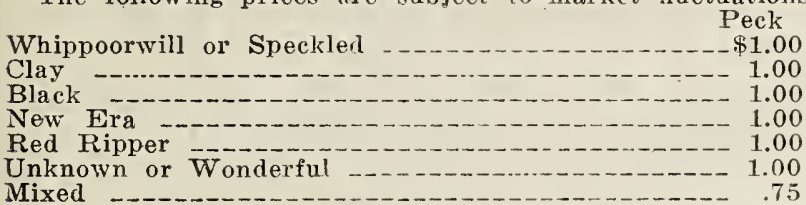

Bushel 1.00 00 00 (1.00 Mixed

COW PEAS MIXED WITH SOJA BEANS

The advantage of sowing Cowpeas with Soja Beans for hay is that the strong stiff stalk of the beans holds up the peas so that they can be cut better and they cure better and make better and more hay

\section{SEED RYE}

$\begin{array}{ll}\text { SEID } & \text { RYY } \\ \text { Bushel, } & \$ 1.75\end{array}$

WHITE TABLE PEAS CAIIFORNIA WHTTE BIACK EYI-Very large, kidney shaped Peas maturing the earliest of all. Fine for early market. One quart, $35 \mathrm{c}$, postpaid. By express or freight, 1 quart, $30 \mathrm{c} ; 1$ peck (15 lbs.), $\$ 1.85$; 1 bushel (60 lbs.), $\$ 6.00$

IARGE BIACK EYI-1 quart, $35 \mathrm{c}$, postpaid. By express or freight, quart, 30c: 1 peck $(15$ lbs $), \$ 1.85$ bushel (60 lbs.), $\$ 6.00$

SUGAR CROWDER-1 quart, $35 \mathrm{c}$ postpaid. By express or freight, quart, 25c; 1 peck (15 lbs.), \$1.85

IADY PEAS-1 quart, $35 \mathrm{c}$; post paid. By express or freight, 1 quart $25 \mathrm{c} ; 1$ peck $(15$
$(60$ lbs. $), \$ 7.00$

\section{SPRING BARLEY}

\section{BEARDED-Very much like ord} aary Barley in grain and growth. I is an early and quick grower. Price. 1 bushel, $\$ 1.50$.
CANADA FIELD PEAS

These Field Peas are entirely different from Cow Peas, re fuiring to be sown early in the spring, making their crop ready for cutting in May or June. They are increasing in popularity every year, making a most satisfactory and large-yielding early forage crop. They can be sown in open weather during December, January, February and March and make large yields of that nutritious food, which can be used either green or cured for hay. It also makes crop equal in this respect to the Cow Peas. They can be sown als alone at the rate of $1 \frac{1 / 2}{2}$ to 2 bushels to the of oats, rye or barley will increase the yield and help to support th pea vines when the crop comes to maturity. Price, 1 quart, $30 \mathrm{c}$ postpaid. By express or freight,

\section{SUDAN GRASS}

In the year of 1909 a small anount of this seed was brought int this country from Sudan, Egypt, by the United States Departmen of Agriculture. It has been tested since its introduction at several points in the United States. Since its introduction it has shown remarkable adaptability to all climatic conditions. It is the greatest drought resisting forage crop known, at the same time it does not blight where the moisture is heavy. Under good seasonable conditions it yields a larger tonnage of hay per acre than any of the hay crops known. Sudan Grass is a tall annual grass, which under seasonable conditions reaches a height of from seven to nine feet. The stems are small and somewhat more leafy than Johnson Grass, which it most resembles, though it is entirely distinct from Johnson, Grass. It is thought to be the original form Cultivated Sorghums. It is thought to be the original form of Sorghum crop or Millet each year and must be seeded each spring. It lacks the underground root stock of Johnson Grass and does not spread like Johnson Grass. It is readily cured into hay and stock of all kinds eat it readily and will leave any other hay to eat it. It has no baneful effects following feeding to work stock. The yield per acre is approximately 500 pounds. The tonnage of hay from one to one and one-half tolis per acre to each cutting. planted in cultivated rows, in close drills or broadcast. In culti vated rows, 36 inches apart, it requires from $1 \frac{1 / 2}{2}$ to 3 pounds of seed per acre. In drills 18 inches apart, use 6 pounds per acre be planted after all danger of frost is past and the ground thoroughly warm, as the young plant is more tender than sorghum. It should be planted as soon as danger of frost is past, in order to cive time for several cuttings during the season. The crop should be cut for hay as soon as the grass is fully headed. If grown for seed, it should be cut when the seed is ripe and fully maturer. Price, 1 lb., $35 \mathrm{c}$, postpaid. By express or freight $25 \mathrm{c}$ per pound.

\section{SUNFLOWER}

A small patch of cultivated sunflowers will produce ar immense amount of the very best poultry feed for winter Drill in rows, cut with a corn harvester, dry thoroughly and let the fowls do the threshing. If you can't spare land for cultivating. Plant them in waste corners. Ornamental varieties are listed with flower seeds.

MAIMMOTH RUSSIAN-An extremely large sunflower. $1 \mathrm{lb}, 20 \mathrm{c}$ postpaid. By freight or express, not prepaid, 10c per pound.

PRICES SUBJECT TO CFANGE WITHOUF NOTICE.

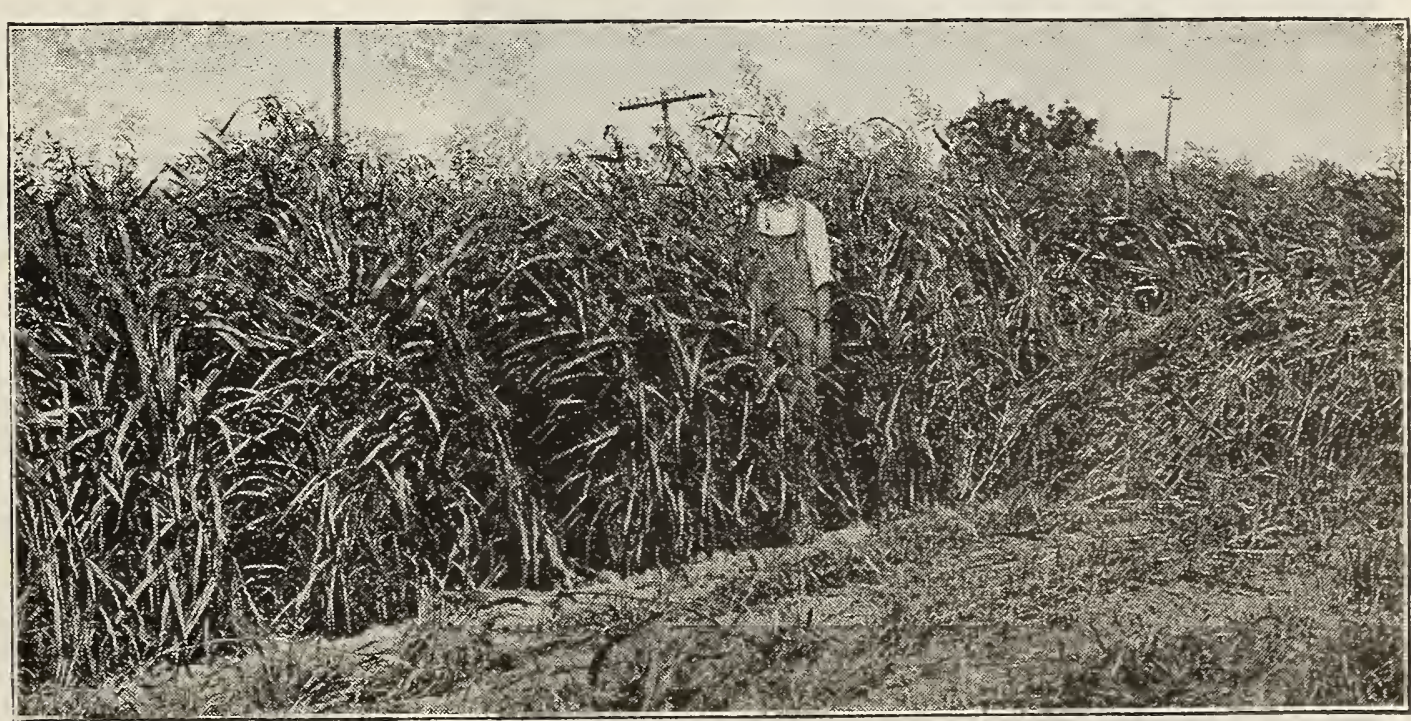

A SHOWING OF SUDAN GRASS 

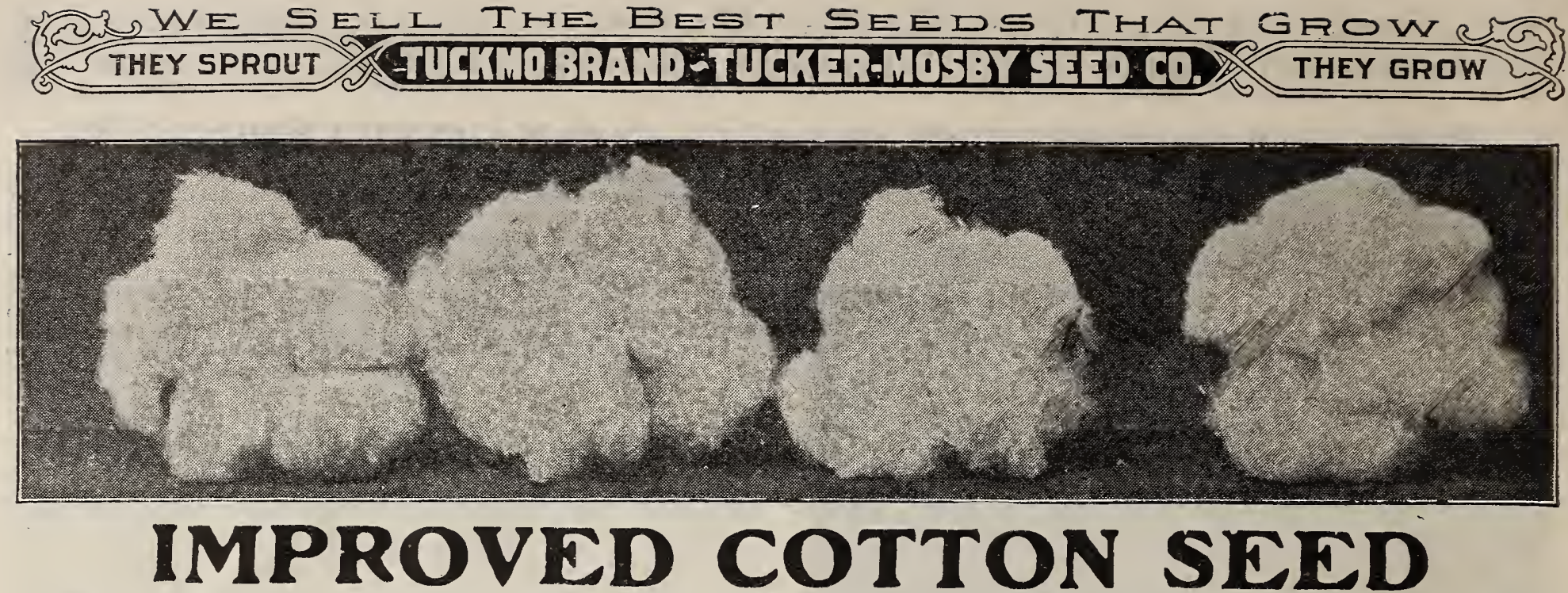

To the Cotton grower there is nothing quite as important as the selection of the proper seed for his soil and conditions, and when the variety is chosen that it should be also selected for its vigor and cotton production pedigree and our offerings are selected for these attributes. Almost every seed must be changed every few years or it "runs out" and does not give the crop it should. Even though you make no change in the variety new seed will much more than repay its adidtional cost

FXPRESS 350 - It is an improvement over the Old Fashion Express. It is earlier and produces larger bolls and easier and turns out a better percentage of lint cotton. It is a good cotton to plant
in boll weevil sections on account of its earliness. It is a remarkable healthy variety, very resistant to diseases affecting the cotton. It does not fall out and a heavy producer. Bushel (30 lbs.), $\$ 2.25$; TRICE'S PARIY BIG BOII COTTON-Trice's is the cotton for boll weevil sections on account of its light foliage and extrene
earliness. The lint will run on good soil $11 \%$ inches and turn earliness. The lint will run on good soil $11 / \mathrm{s}$ inches and turn
out 30 per cent at the gin. Large bolls. plant mediun to tall, short limbs up to top; two to three large limbs at the bottom. Grows trim, Storm proof, but easily picked. By freight, 1 bushel, $\$ 2.25$; per 100 lbs., $\$ 6.00 ;$ per ton, $\$ 110.00$.
COIUMBIA EARIY BIG BOJ

DLATE COTON-An improved big boll staple variety. Plants tall and branching; length of staple, which is strong in texture, is $11 / 4$ inches; large locks and
will gin out 35 per cent. Will vield a bale to the acre, and matures medium early, therefore well adapted to all boll weevil sections. One bushel, $\$ 2.25$; per 100 lbs., $\$ 6.00 ; 1$ ton, $\$ 110.00$.

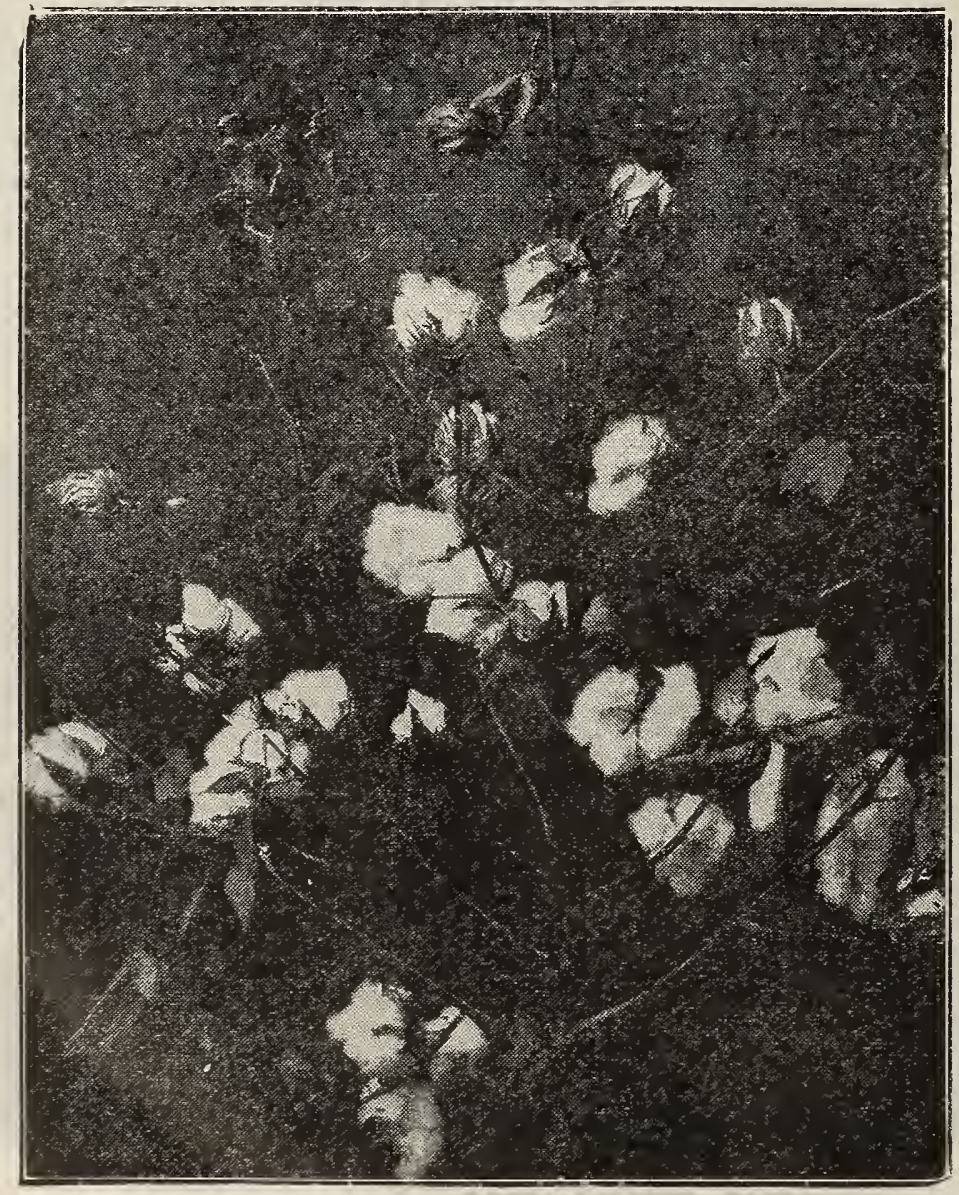

EARIY TRIUMPE BIG BOII COTYON-It is the earliest of all big boll varieties, being only a week later than King's Early. As of it in -proof cotton in beats a variety. It makes 36 to 41 per cent lint (36 to 41 pounds of lint to 100 pounds of seed cotton). Thi cotton has a strong, thrifty, deep-rooted, mediun sized, well-shaped stalk; bolls are ustally five lock, very large and solid, therefore making more cotton than other spongy large bolls. Lint of the Triumph Cotton is silk and stronger than that of any other variety. $11-16$ to $11-8$ inches in length. One bushel, $\$ 2.25 ; 100$ lbs., $\$ 6.00$ 1 ton, $\$ 110.00$.

KING'S IMPROVED-One of the best kinds to plant in this section, either in bottom or hill land. Owing to its peculiar branching habit, it is a very prolific variety. Extra early and can be planted as late as July 1; will mature good erop. 1 bushel. $\$ 2.25$; 100 lbs. W6.00; 1 ton, $\$ 110.00$

WANNAMAKER'S CIEVELAND BIG BOIL PROIIFICSince its introduction this cotton has been very generally grown
throughout the Cotton States, and has unquestionably put itself in first place with many of our most progressive cotton planters. It has large bolls and good fibre, which measure often from 1 inch to 1 1-16 inches. Very early in maturity, about 40 per cent lint; carries less foliage than most other varieties. It does remarkably well in Louisiana, Mississippi and other Southern States. It is practically free from anthracnose, suffering less than most big bolls. The stalks are branching in growth, with five to six primary limbs; the firs imbs are long and begin near the ground, an essential feature in early cotton, 1,350 pounds per acre has been gathered from it this 100 lbs., $\$ 6.00 ; 1$ ton, $\$ 110.00$. SIMPKIN'S PROIIFIC COTTON-The Boll Weevil Deceiver. Strictly North Carolina Seed. Eighty days from planting to boll. This cotton has become well known throughout the state, and an extended description is unnecessary. Don't put faith in the newfangled varieties so highly boosted by get-rich-quick seedsmen. Stick to the old reliable sorts that have proved to be reliable and trustworthy. Every rear there are hundreds of new sorts pushed to the front with absolutely no good improved features. Simpkins is acknowledged to be the hardiest, most uniform in maturity and earliest of all varieties, with the possible exception of my Re-Im-
proved Early King. Simpkins has produced as much as three bales proved Early King. Simpkins has produced as much as three bales to the acre, averaging 40 per cent lint, and in tests made at the Arlansas Experiment Station, it areraged first out of twent
varieties. 1 bushel, $\$ 2.25 ; 100$ lbs., $\$ 6.00 ; 1$ ton, $\$ 110.00$.

MONEY MAKER-An excellent early variety for boll weevil districts. A short style but heavy yielder. 40 per cent lint. Money Maker Cotton was justly named. It has certainly been a money maker for many a planter this season. We have received lots of reports of a half and three-fourths of a bale to the acre, right in boll weevil sections. Money Maker is an early cotton, the growboll weevil sections. Money Maker is an early cotton, the growing type of which is small, somewhat on the order of It is a heavy yielder and gives excellent "turn-over" of lint. Our seed is furnished by experts. We have been handling their seed for years and they have given entire satisfaction. You take no chances when you buy your cotton seed or any other seed from us. Prices 1 bushel, $\$ 2.25 ; 100$ lbs., $\$ 6.00$; ton, $\$ 110.00$

HAIF AND HAIT-So named because it yields nearly half seed and half lint, very short staple; many growers favor this cotton; while others are very much against it, owing to the short staple. While others are very much against it, owing to 40 to 48 per cent lint at gin. 1 bushel, $\$ 2.25 ; 100 \mathrm{lbs}$.. $\$ 6.00 ; 1$ ton, $\$ 110.00$. CHRISTOPHER'S IMPROVED BIG BOII-Boll very large, forty of them making a pound of seed cotton; five to seven locks to the cluster. Seed cotton about forty per cent lint, easily picked. lbs., $\$ 6.00$; per ton, $\$ 115.00$.

ROWDEN'S BIG EOII-This is considered by many planters 


\section{COTTON SEED-Continued}

centage of lint averaging 33 1-3 making a fiber of 1 1-8 inch. The stalks are of heavy branching and producing large five lock bolls easily picked. Per bushel, $\$ 2.25 ; 100 \mathrm{lbs} ., \$ 6.00 ; 1$ ton, $\$ 110.00$. WEBBER 82-The great productiveness, uniformity, and other high characters of this strain makes it a very popular staple variety of Cotton. It is a fraction later than the Webber 49 and has a little longer staple which is also uniform. The plant is tall with apparently thin foliage making fruit from

WrBBER 49-One of the best strains of long staple varieties, heavy yielder, quick maturing. The percentage of lint will average 33 1-3 per cent and its picking and storm proof qualities are excellent. It produces a staple in this section from $13-16$ to 13.8 inch. It makes comparatively small weed, thin foliage and puts on heavy fruiting branches near the ground with large bolls. Per bushel, $\$ 2.25: 100 \mathrm{lbs}$. $\$ 6.00 ; 1$ ton, $\$ 110.00$.

HARTSVIIIE (STAPIE)-It is a very large growing variety of Cotton, very hardy, and it seems to be well adapted to all types of soil. It is a large boll variety not as early as other varieties. makes a good percentage of lint and produces a strong even rum
ning staple of $13-8$ inches. Per bushel, $\$ 2.25$; per 100 lbs., $\$ 6.00$ per ton, $\$ 110.00$

HEAVY FRUITER-This is one of the most productive types of Cotton of the short staple varieties. Medium size bolls, easily picked and does not fall out. It produces a strong stalk, thin foliage with heavy fruiting branches. It seems to be well adapted to all types of soil. Will average 40 per cent lint or better which is uniform and will pull one inch under favorable conditions. Per bushel, $\$ 2.25$ per hundred, $\$ 6.00 ;$ per ton, $\$ 110.00$

Corthe most satisfactory results. It he plant is o oblong with short blunt point. The lint will pull strong $11-8$ inch and the percentago of lint will average 33 1-3. It is considered one of the most desirable sorts to plant in sections infested by the
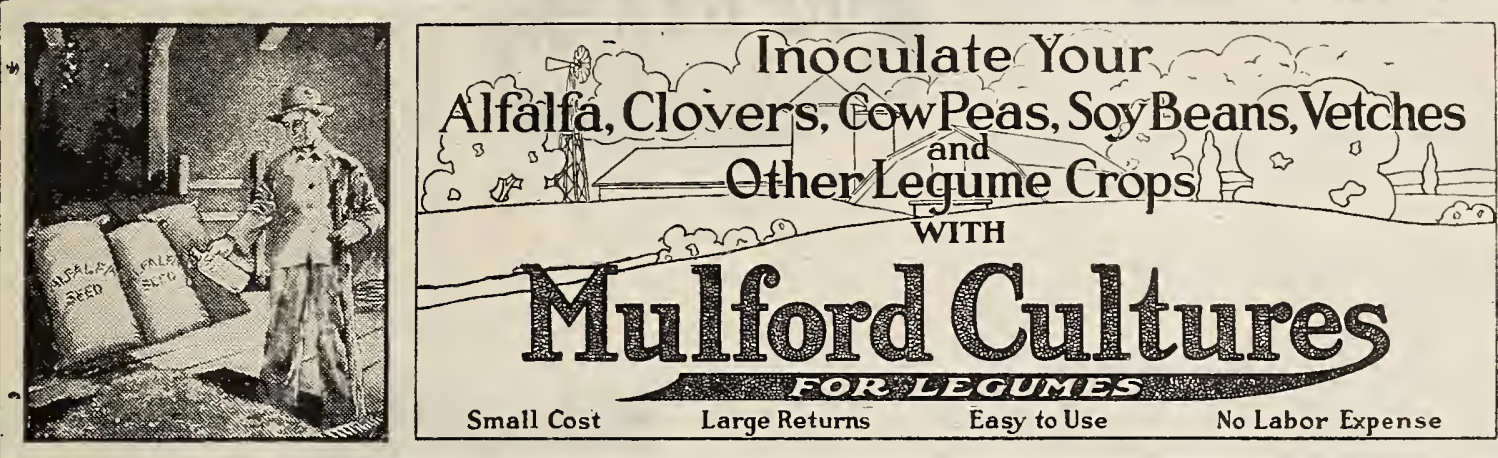

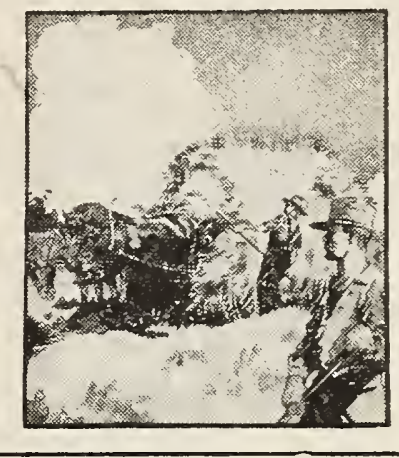

HOW MULFORD CULTURES ARE USED

Mulford Cultures for Legumes are very easy to use, no special knowledge, no experience and no special implements being required. It is only necessary to add water to the bottle (which is intentionally only about one-fourth filled), shake well, and then damper with this mixture the seeds or soil, which will not interfere with planting.

\section{WHAT MULFORD CULTURES ARE}

Mulford Inoculating Cultures contain pure, tested strains of active, nitrogen-fixing bacteria, grown on specially prepared media (a jelly-like mass), and are furnished in flint glass bottles with rubber stoppers. They have recently been improved by adding a new ingredient to the culture medium, changing the color of the cultures to yellow, encouraging a more prolific growth of bacteria increasing the virulence of bacteria, and prolonging the life of culture.

THE UNITED STATES DEPARTMENT OF AGRICULTURE and many State Agricultural Experiment Stations recommend inoculation of legumes with nitrogenfixing bacteria to induce a prompt "catch" and increase your vield.

\section{PRICES OF MULFORD GULTURES}

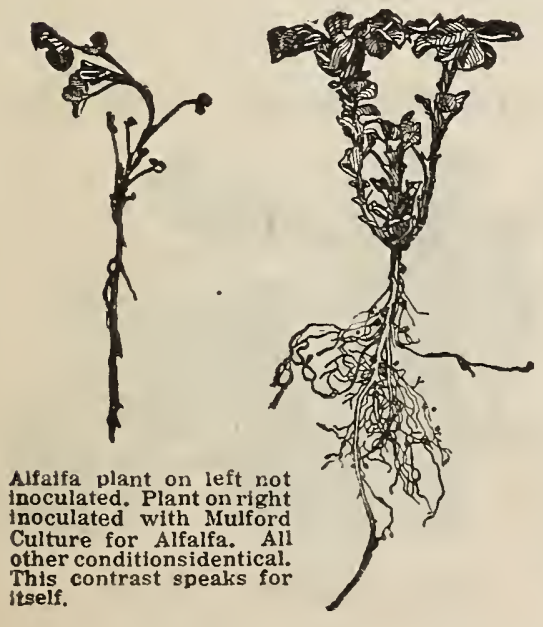

Five-acre size, $\$ 5.00$

One-acre size

Lima Beans and Sweet Peas)

These prices include delivery on freight shipments.

Mulford Cultures Are Prepared For:

Alfalfa

Crimson Clover

Sweet Clover

Red Clover

Alsike Clover

Bur Clover

Cow Peas

Soy Beans

Peanuts

Always specify on your order what crop you want to inoculate, as there is a differ-

ent strain of bacteria for each legume.

Velvet Beans

Sweet Peas

Garden Peas

Grarden Beans

Lima Beans

Lespedeza

Beggar Weed

And Others.

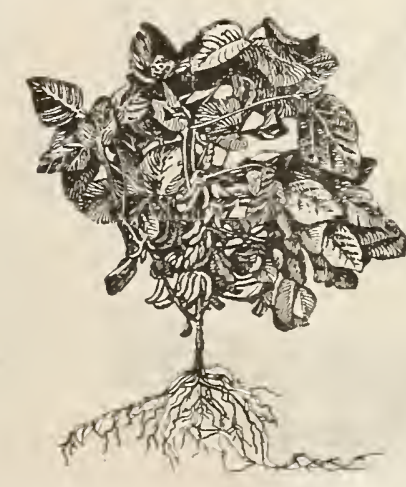

Notice how much bigger inoculated than uninoculated. actual photograph.

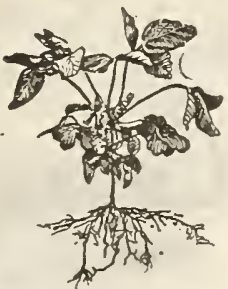




\section{INSECTICIDES}

\section{BORDEAUX MIXTURE}

For blight, mildew and all fungous diseases. Can be used alone or in connection with Paris Green or Arsenate of Lead. For hardy foliage, such as apple, pear, potato, tomato, egg plant, use 8 to 12 cherry and cucumber, 6 to 8 pounds in 50 gallons of water. B express or freight, 1 quart, $65 \mathrm{c} ; 1$ gallon, $\$ 2.25$. By parcel post, add $10 \mathrm{c}$ per quart.

\section{DRY POWDERED LIME SULPHUR}

This is the standard remedy adopted and recommended by practically all of the experiment stations for destroying San Jose and Oyster Shell Scale. It is to be diluted 1 to 10 , and sprayed or applied to trees while they are dormant in fall or winter. It is also highly recommended as an insecticide and fungicide, killing spores of fungi, and, as an insecticide, acts as a constant poison for
sucking insects and mites. 1 lb., 40e, postpaid. Not post paid. 1 lb., 30c; 100 lbs., 20c per pound.

\section{ARSENATE OF LEAD}

One of the best and most effective poisonous insecticides for leateating insects, and more especially adapted to trees and shrubs as it adheres to the foliage better, is not so liable to be washer off by rains, and does not burn.

\section{ARSENATE OF LEAD, POWDERED}

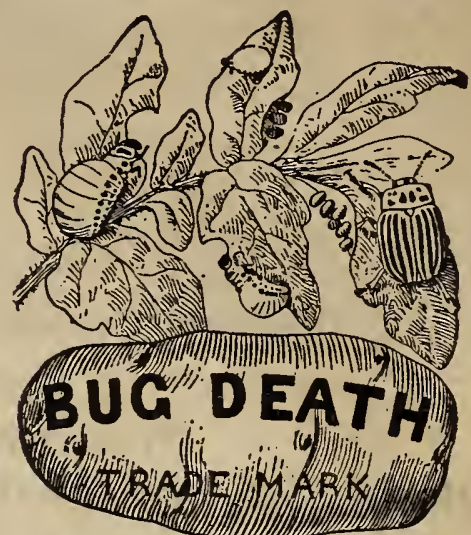

Pat. March 16 and Nov. 9, 1897.

Pat. in Canada Nov. 2, 1897 , and Jan, 25. 1000
BUG DEATH

A new powder that eifectually takes the place of Paris Green and other dangerous and poisonous insecticides. Absolutely safe to use as it contains no poison what ever. Send for circulars. $1 \mathrm{lb}$. $35 \mathrm{c} ; 3$ lbs., 75c; 5 lbs., $\$ 1.00$ $12 \frac{1}{2}$ lbs., \$2.00, postpaid. Not prepaid, 1 lb., $25 \mathrm{c} ; 3$ lbs., $65 \mathrm{c}$; lbs., $\$ 10.00$.

\section{ARSENATE OF CALCIUM}

For spray and dusting. It has been recommended by many agri cultural agents to use to destroy boll weevils and Army Worms on cotton. This has been tried ou and has proven successful. It is also very fine to destroy an pre vent insects on fruit trees. shade trees, tobacco, shrubbery, roses, etc. $1 / 2$ lb., 25c; 1 lb., $35 \mathrm{c}$; 5 ths., $\$ 1.50$, postpaid. By freight or express, $100 \mathrm{lh}$, drums, $20 \mathrm{c}$

One lb., 60c; 2 lbs., $\$ 1.15 ; 5$ lbs.,

\section{HAMMOND'S SLUG SHO'}

One of the best vegetable insecticides in use. Specially recommended for destroying the cabbage worm, potato bug, tobacco worm and other insects that prey on vegetation. Gardeners need have no fear about applying this, as it is not dangerous to handle like Paris Green, etc. Non-poisonous to human life. Price, 1 lb. $35 \mathrm{c}^{\circ} 5$ tbs, $85 \mathrm{c}$, post

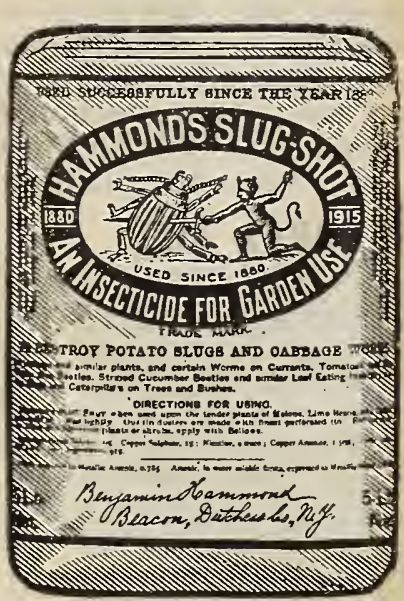

\section{PARIS GREEN}

For liquid spraying. Use one pound of Paris Green to 100 or 200 gallons of water according to strength de sired. It will be found generally strong enough if onehalf pound is stirred in a barrel ( 50 gallons) of water and allowed to stand 24 hours before using. Care must be taken in using all poisonous liquids that animals are not allowed to get at them. In using Paris Green in powder form use one pound of Paris Green and 20 to $\overline{5} 0$ pounds of flour; mix thoroughly and apply evenly, preferably when the dew is on th
paid. Not prepaid, 1b., $50 \mathrm{c}$.

\section{MEASURING INSECTICIDES}

The following table will be helpful to the amateur in diluting any spray material, viz:

One part spray material to 100 parts of water means--

1 teaspoonful to one pint of water.

4 tablespoonsful to one gallon of water.

$1 / 2$ pint to six gallons of water.

1 pint to twelve gallons of water.

$1 / 2$ pint to twelve gallons of wat

$1 / 2$ gallon to one barrel of water.

of spray material to above amount of water.

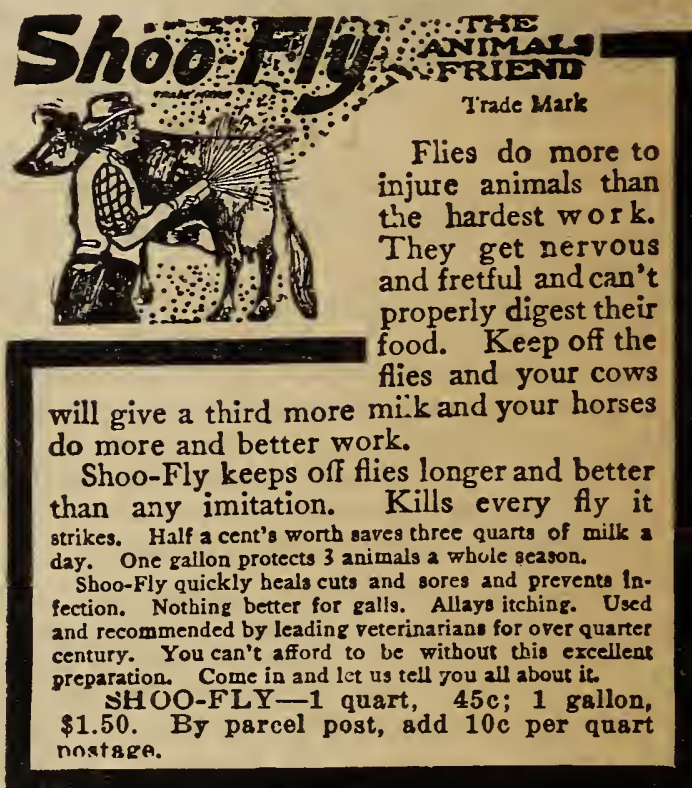

\section{BROADCAST SEED SOWERS}

Wheelbarrow Seeder. Hopper 16 feet in length, equipped to plant all kinds of grasses, clovers, wheat, oats, rye, alfalfa, etc. One of the most satisfactory seeders. Price, each, $\$ 12.00$.

ACRE-AN-HOUR SIFTER A splendid little hand implement for applying Bug Death;

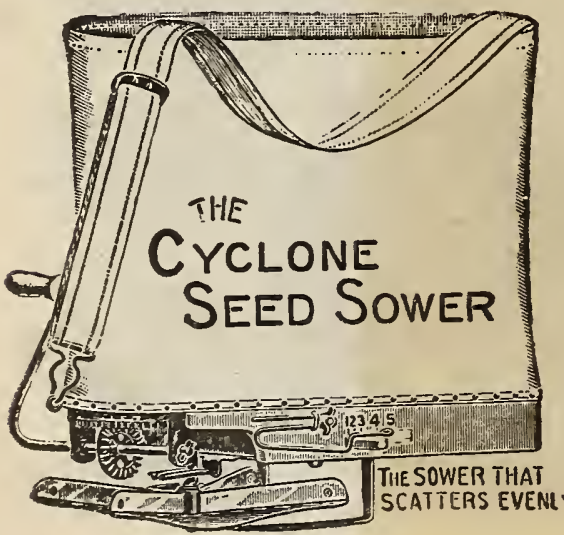

\section{BROADCAST} SEEDERS

The Improved Cyclon Seeder will sow all varieties of farm seeds that can be sown broadcast and with ease to the op erator. Five acres pe hour is the average for the Cyclone. The seed is distributed evenly and with great saving of time which makes this a very practical machine on any kind of farm. It increases profits both ways-in better crops. in time and seed saved. By expres or freight, $\$ 2.00$. By

\section{CAHOON BROADWAY SEED SOWER}

For sowing seed, grain, clover, etc. The best seeder manufactured, and sows all kinds of grain, clover seed, etc., rapidly and evenly. A person entirely unused to seeding can, by following the simple directions sent with the machine sow four to six acres per hour at a common walking gait. It sows uniformly and saves four-fifths in labor by its use. Every farmer should have one of these sowers. By express or freight, $\$ 4.00$ each. By parcel post, $\$ 4.25$ each.

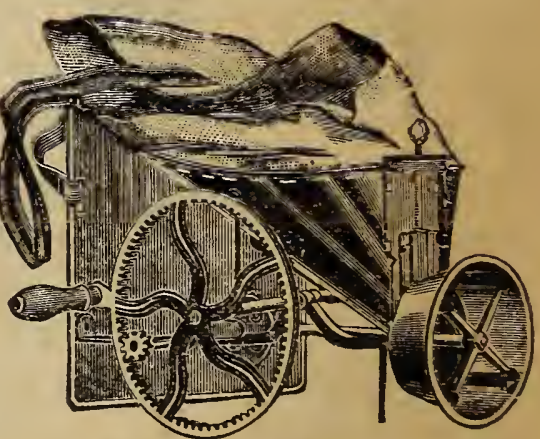

THE CAHOON SFPDFR 


\section{ORDER SHEET \\ Tucker-Mosby Seed Company} TUCKMO BRAND SEEDS

60 SO. FRON'T STREET

MEMPHIS, TENN.

Shall we ship by Mail,.Freight or Express..........

Name

Post Office

Box No........R. F. D. No........ State........

Street No.

Ship to (Station)

By Express or R. R. Co.

Please write Name and Address very plainly in the above.

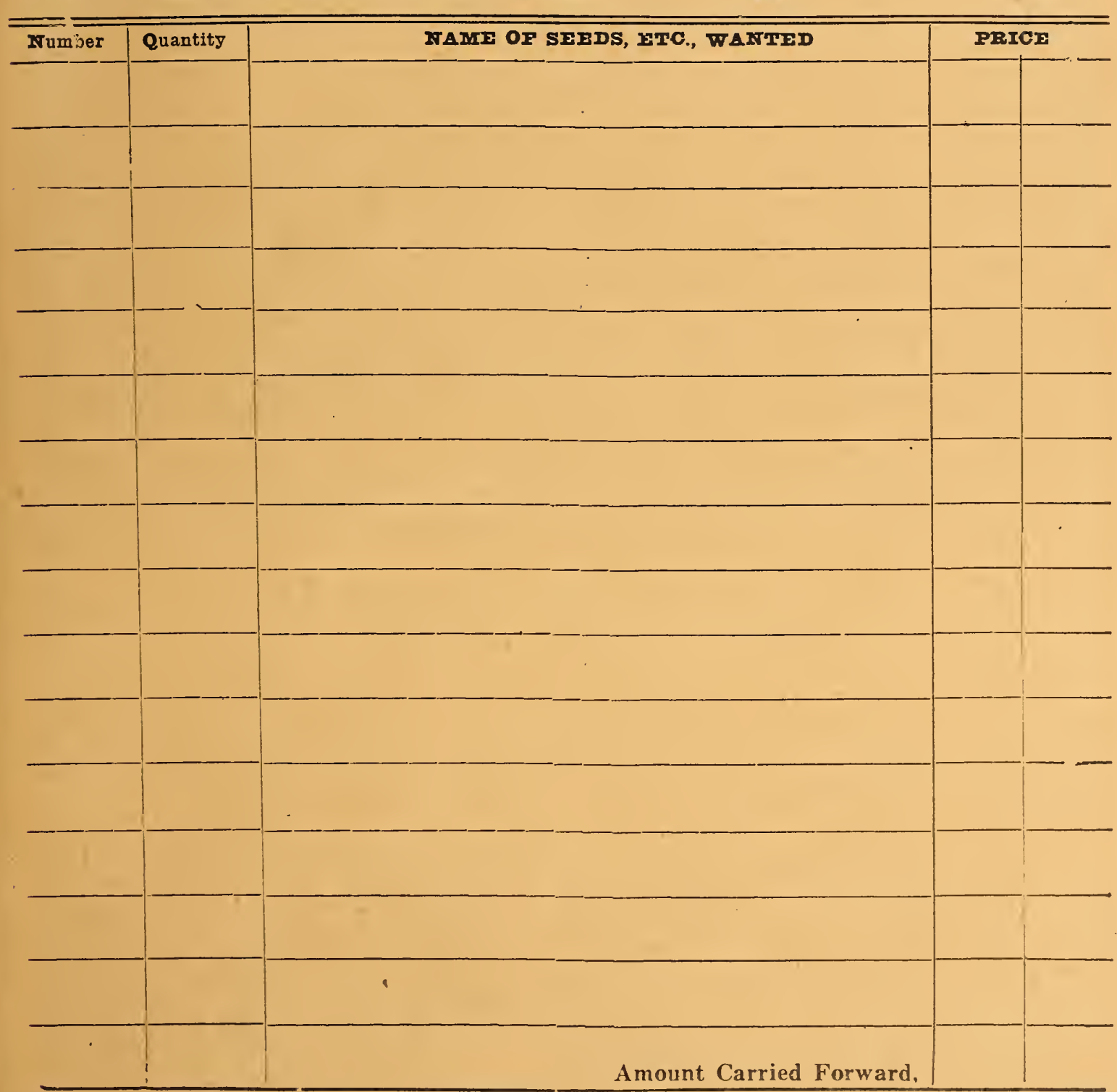

No.

Date rec'd

Checked by

Wrapped by

Date Sent

$\mathbf{P}$.

THE AMOUNW MCTOSED

Fxp. Money Order \$.

P. O. Money Order

Bank Draft ....

Stamps ......

Cash .

Total

... 


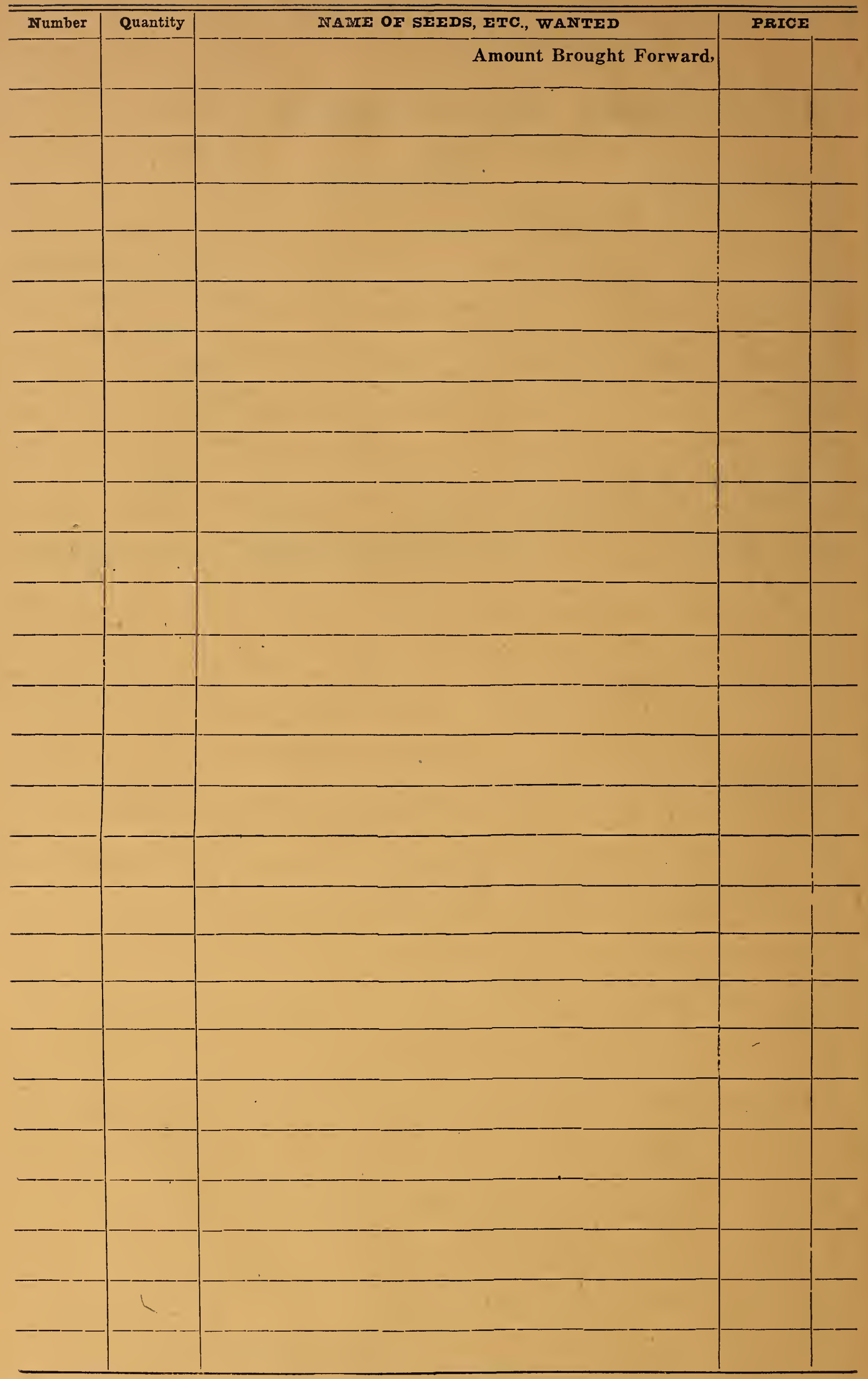




\section{WE SELL THE BEST SEEDS THAT GROW}
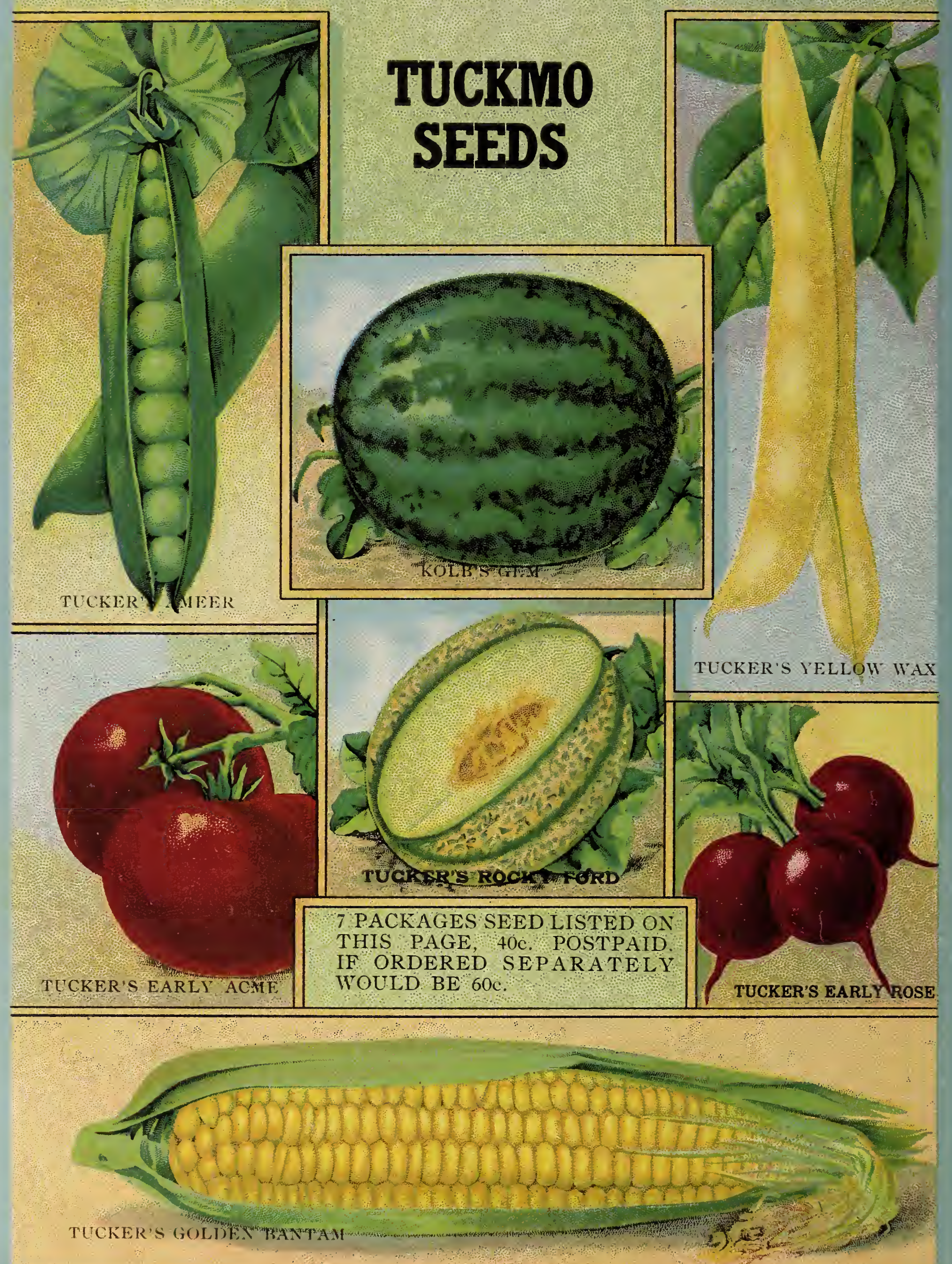